\title{
The
}

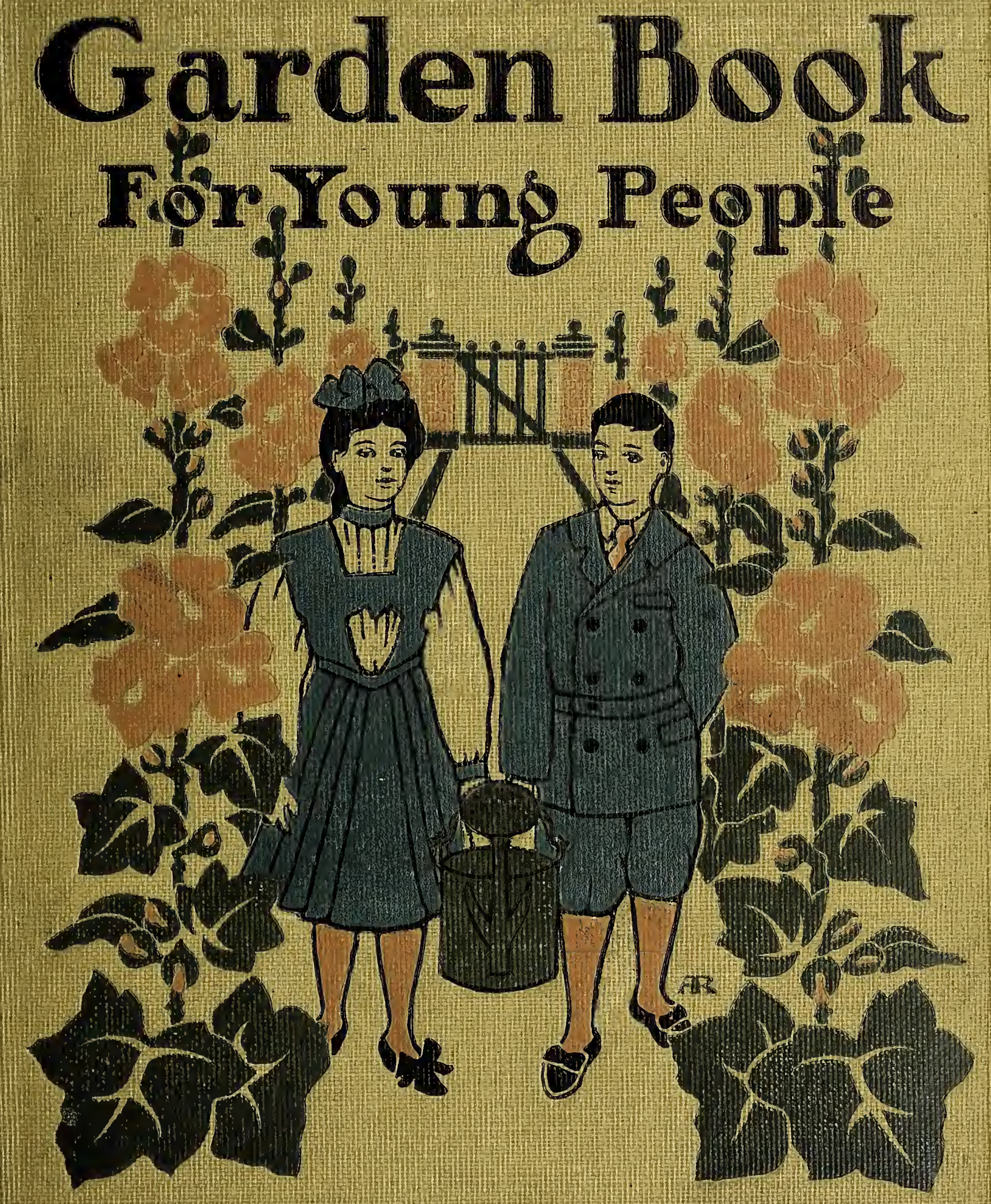

Alice Loumslb erry 





\section{THE GARDEN BOOK FOR YOUNG PEOPLE}






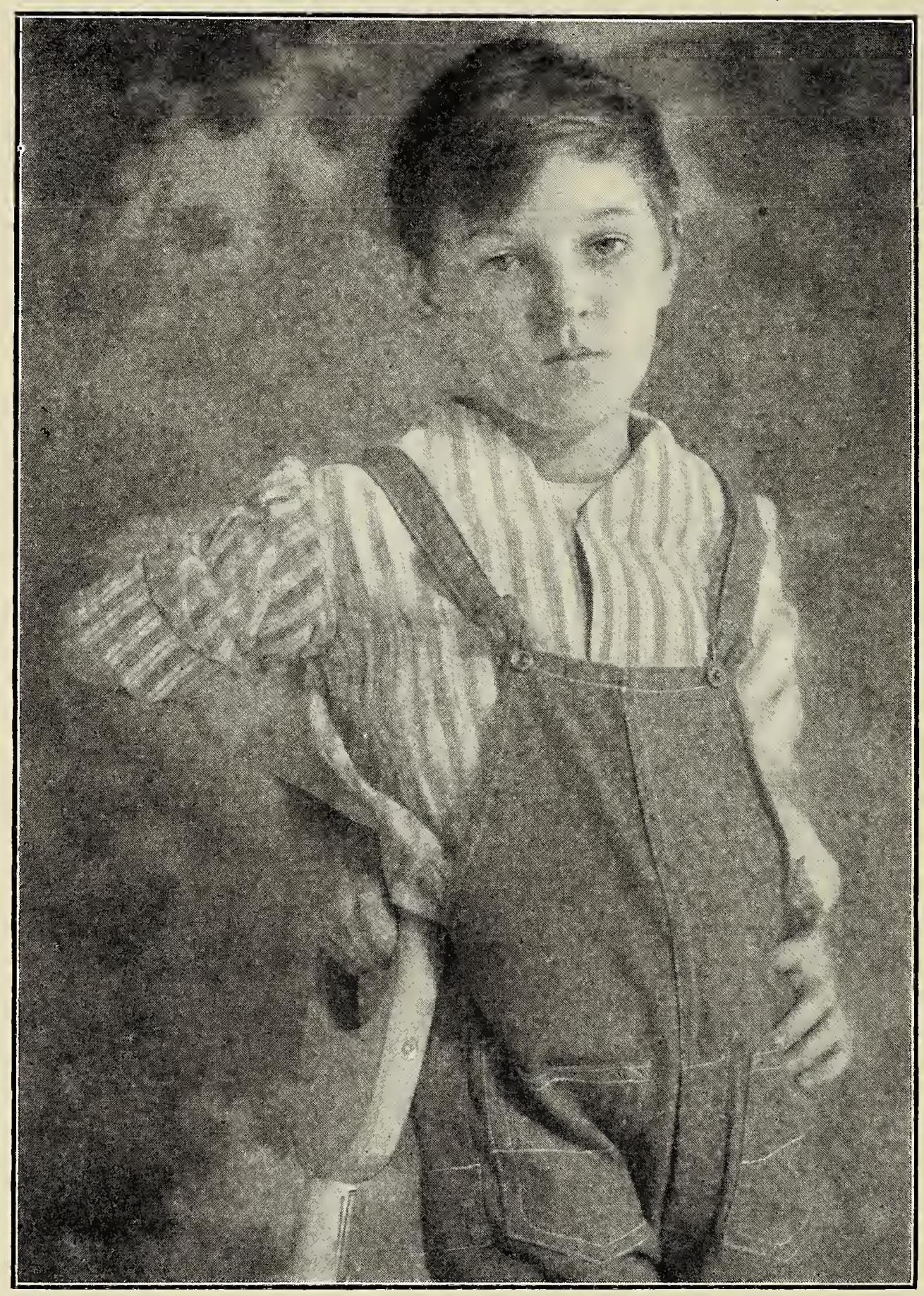

PLATE I.-JOSEPH WAS THE REAL GARDENER 
Hort.
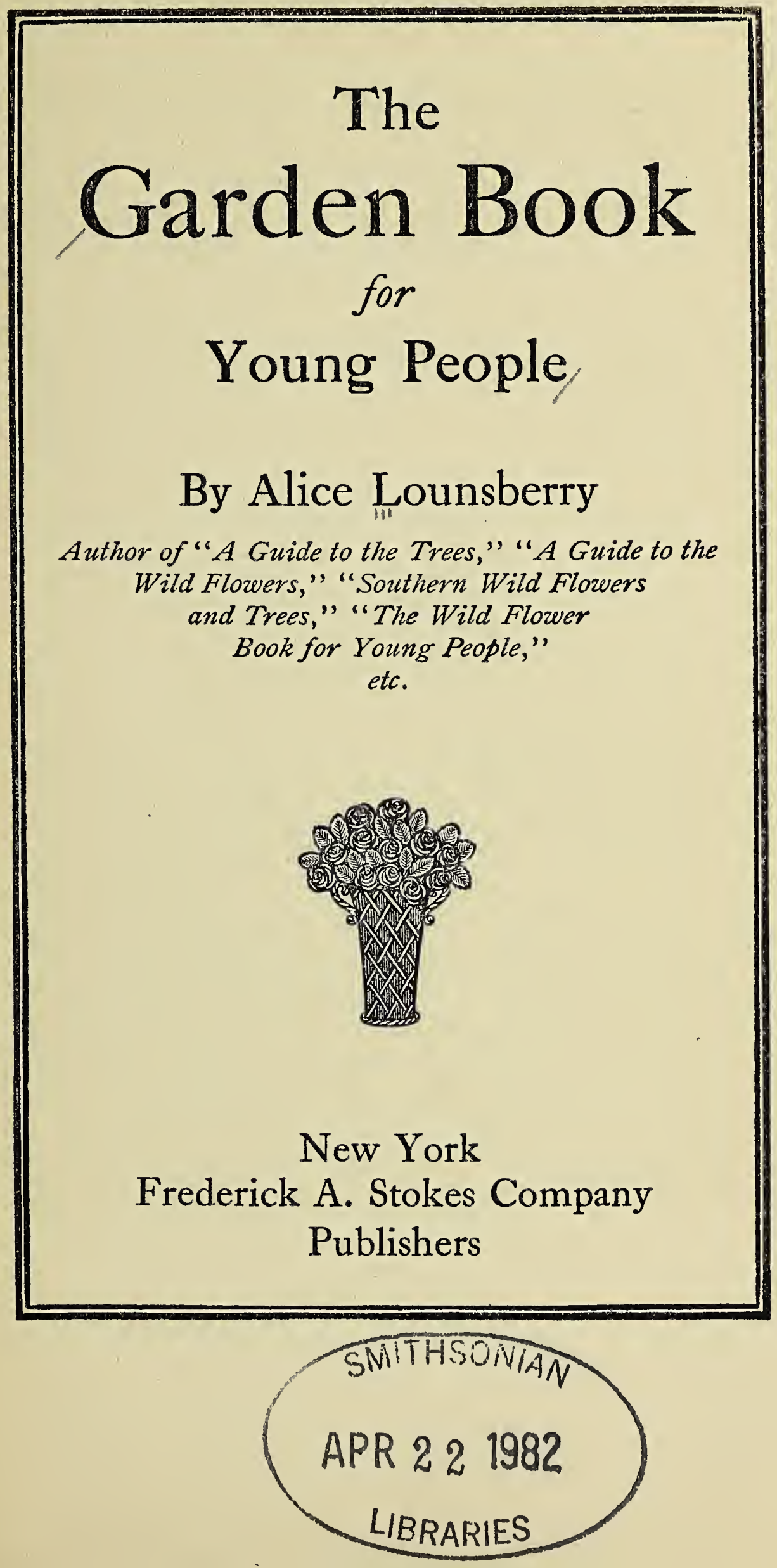
COPYRIGHT 1908, BY

FREDERICK A. STOKES COMPANY

\author{
March, 1908 \\ All rights reserved
}




\section{PREFACE}

THIS book tells the story of a young girl and her 1 brother Joseph, who utilise a triangular strip of ground for planting a flower garden. The girl loves her roses best, and the boy finds delight in working the soil and in tending his hardy plants. Together they sow seeds and watch for them to sprout; they set out young plants and wait in patience until their flowers unfold; they wage war with weeds and insect pests, and, at length, prepare to meet the winter.

These young people learn the habits of birds that build nests among the flowers and in the bordering coppice where shy wildlings grow. Their life is far from dull.

Older inhabitants of the suburb, who have beautiful gardens, become interested in the desire of Joseph and his sister to make their home attractive, and continually encourage and teach them. The garden is their meeting place of work and play and their opportunity for studying the out-of-door world, the secrets of which they would gladly share with the reader.

\section{A. L.}





\section{CONTENTS}

CHAPTER

PAGP

I-The Decision ............. I

II-Early Preparations . . . . . . . ... 9

III-The First Planting.......... I7

IV-Miss Wiseman's Suggestions....... 24

V-A Day's Hard Work......... 32

VI-Joseph Does Some Transplanting. . 40

VII-Making the Seed and Flower Beds 48 VIII-Planting in the Seed-Bed....... ${ }_{56}^{6}$

IX-Joseph Continues Sowing Seeds.... 64 X-Finding Ferns to Transplant..... 72 XI-My Rosarium ............. 80

XII-Planting Before the Wall....... 88 XIII-Joseph Completes the Planting of the Garden ............ 96 XIV_May Time ............... I04 $\mathrm{XV}$-About Wild and Cultivated Flowers I I 3 XVI--The Last May Days........... I 22 XVII-The Opening Day for Roses...... I30 XVIII - The Comedy of the Garden...... I 138 vii 
viii

\section{CONTENTS}

CHAPTER

PAGE

XIX-A Day of Play............ I 47

XX - The Garden Gives Its Reward... I 55

XXI-The Drought ........... I63

XXII-Our Phloxes and Heliotrope.... I 7 I

XXIII - The End of the Drought....... I79

XXIV-The Fall of One of the Spruces.. I 87

XXV-Our Golden Glow and Hollyhocks 195

XXVI-Water Gardens and Other Things 203 XXVII-Early August Days.......... 2 I I XXVIII-Little Joseph Wins the Tournament ............. 2 I9

XXIX - The Return Home......... 227

XXX-September Days .......... 236 XXXI-Getting Ready for Bulb-Planting 244 XXXII-Chrysanthemums ......... 252 XXXIII-The Autumn Work......... 26I XXXIV - Days Near Thanksgiving. . . . . . 269 XXXV-The Snow ............. 277 


\section{LIST OF ILLUSTRATIONS}

PLATE

I-Joseph was the Real Gardener,

Frontispiece

II-Map of the Triangle......... I

III-The Bluebirds took Possession of the

House hung to the Tree...... 6

IV_- "Summer is not here"......... 26

$\mathrm{V}$-He slept without rocking........ 38

VI-A Border of Narcissus poeticus..... 52

VII- "I have a bird's egg".......... 60

VIII_Fiddleheads ............ 72

IX-Windflowers .............. 74

$\mathrm{X}$ - "Fronds uncoiled beside some lovely wake-robins" ........... 78

XI-A Rose Fantasy.............. 82

XII__"I may become a Rosarian". . . . . . 86

XIII-Wild Ginger................. . 94

XIV_--Two Spring Orchids............. . 98

$\mathrm{XV}$ - "Blue flowers that should bloom for us soon".............. I00

XVI-"Blowing out his cheeks and breath to keep the moths away"...... IO2 ix 
XVII_ "May in the country is as lovely as June" .............. I04

XVIII_The Wild Blue Flag........ Io8 XIX-Pink Dogwood........... I Io XX-Columbines .............. I I 4 XXI_"Apple blossoms have begun to drop their petals" ........ I 22

XXII-Pointed Blue-eyed Grass...... I 24 XXIII-June Roses ............. I32

$\mathrm{XXIV}$ - "Joseph had to get down on his knees and use the sickle".... I44 XXV_ "The long drive outlined by spruces where the bridal wreath is in bloom"...... I 54 XXVI-"We like to observe these larkspurs" ............. I 56 XXVII_Phlox Drummondi ......... I60 XXVIII-Nasturtiums ............. I70 XXIX-Cosmos .............. I76

XXX-"Their golden cups gleamed as brightly as ever"........ I 84 XXXI- "The foxgloves are still lovely". I 88 XXXII-"Golden glow against the sky". 196 XXXIII_- "He knows without being told just how to handle a plant". . I98 XXXIV_- "Pink, blue and yellow lilies float on the surface"......... 204 XXXV_Countless Irises ........... 208 XXXVI-Rose-mallows .......... 2 I 2 
XXXVII-A Petted Hydrangea........ 2 I 6 XXXVIII_ "Miss Wiseman's narrow path with the hedge on one side and the flowering shrubs on the other" ............. 224

XXXIX-Hydrangeas and Phloxes...... 230 XI-The Tamed Butterfly........ 234 XLI_"Joseph with a large package of seeds, dropping them awkwardly over the ground"... 238 XLII_Wichuraianas over Arches... . . 244 XLIII-The Drive up to Nestly Heights. 248 XLIV-Chrysanthemums in the Glass

House at Nestly Heights... 252 XLV_ "The chrysanthemums that Timothy brought us"...... 254 XLVI-The Men at Work......... 262 XLVII - "Timothy has been in the clutches of the farmer"........ 268 XLVIII - "At the point of the triangle all is dead"...........27? XLIX-"Queenie trudges through the snow" ............ 282 



\section{THE GARDEN BOOK FOR YOUNG PEOPLE}




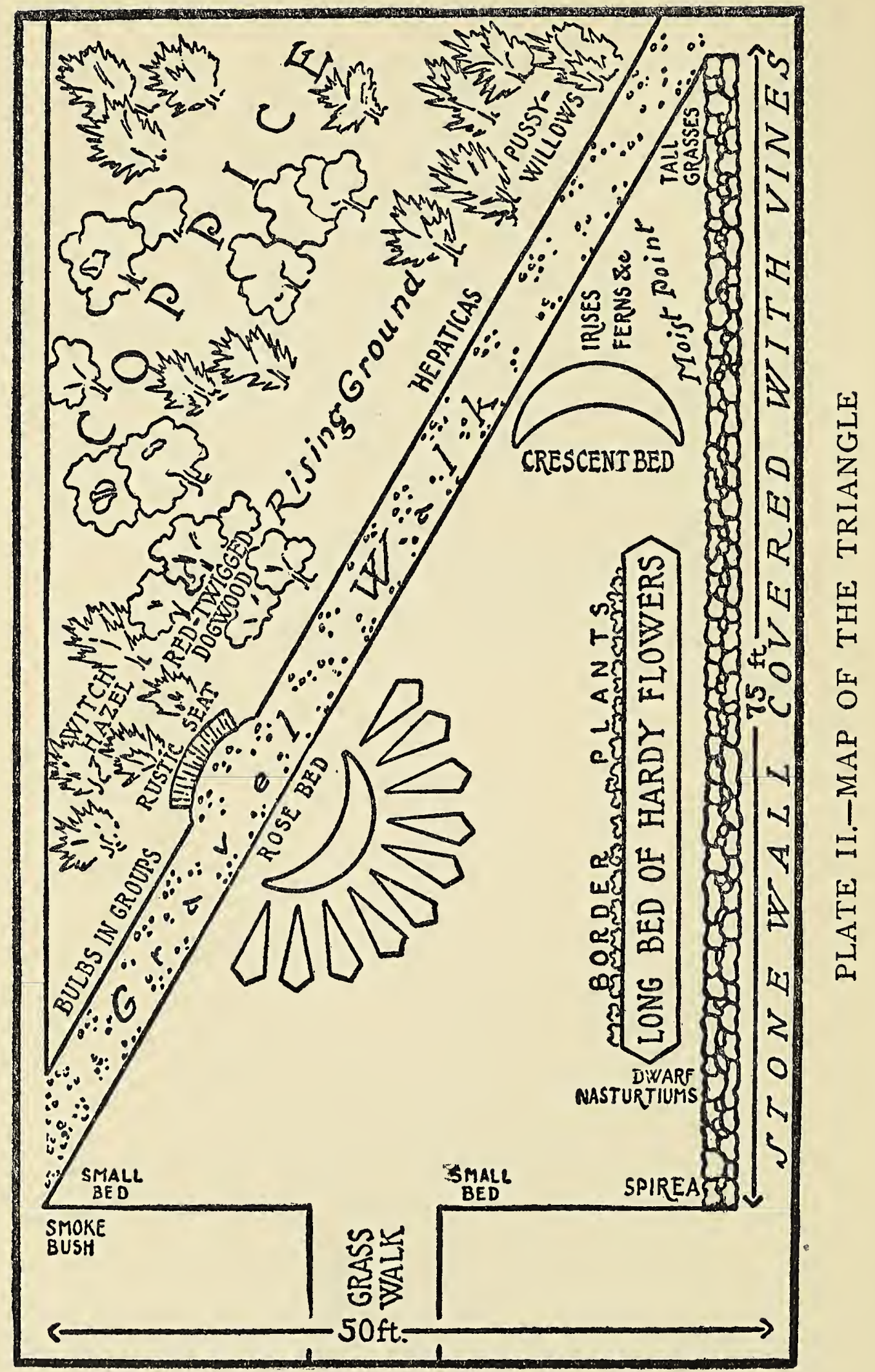




\section{THE GARDEN BOOK FOR YOUNG PEOPLE}

\section{CHAPTER I}

THE DECISION

FOR some time Joseph and I had thought that we should like to have a garden. Not until we inherited the homestead of a great-aunt, however, did we regard our desire with seriousness. Then the first decision we were obliged to make was whether our garden should be of vegetables or of flowers.

The square brick house into which we moved, while March was trying to make us believe it was still winter, stood in the suburb of Nestly, a pretty place, and readily accessible to the city by railway, trolleys and automobiles. It was a suburb where many people lived, and had lost, therefore, the rural charm it possessed in Revolutionary days, when our great-aunt's home had been one of the three 
important places in that part of the country. Nevertheless, in Nestly to-day gardens are still thought quite as important as houses, which can never be true in a large city.

For generations our great-aunt's place has been called the Six Spruces, because at a short distance in front of the house there stands in a circle that number of spruce trees, their great, out-held branches enclosing, according to the season, a summer house or supporting one of snow. Joseph, who is barely thirteen, and much in sympathy with the lore of fairy folk and the adventures of pirates, thinks a great deal of these trees. I am four years his senior, besides being his sister and natural guardian. To me, as to Joseph, these six spruces seem the most wonderful trees in the world.

When my brother and I are alone, I call him "Little Joseph," although he is now so well grown for his age that he dislikes me to do so when neighbours are present. At first we were both chagrined that our inherited mansion was so severe in looks and so dilapidated, because our means for making alterations are small. This, however, has not interfered with Joseph's lasting admiration for the cupola, which reminds him of a sentry box, and neither of us would exchange the Six Spruces for the highly cultivated acres of our neighbour, $\mathrm{Mr}$. Hayden of Nestly Heights.

Within, the seriousness of our aunt's disposition was indicated by the plain furniture and walls, 
while outside, the overgrown and unkempt grounds were evidence of her dislike for out-of-door life and the trouble of flower-growing.

Mrs. Keith stayed with us as a reminder of our great-aunt's day and power. She had been the housekeeper of the Six Spruces for many years, and saw no reason for changing her abode because two children were coming there to grow up. Indeed, Little Joseph and I greatly preferred to have her remain. We had discovered that her heart was good and kind, although from what she said about it we might have believed she had no such organ at all.

Both our near neighbours have gardens for vegetables and for flowers, and their contentment is very great. We hear that last autumn Miss Wiseman, whose place adjoins ours on the north, had a single dahlia, larger and finer than any which unfolded at Nestly Heights. Earlier in the season, however, the beets grown by Mr. Hayden's gardener were somewhat sweeter than her own, so the dahlia was doubly prized as making up for their deficiency. Hearing our neighbours argue whether it was more pleasing to plant pansies by themselves, or to use them as ground covers for rose-beds, we became convinced that great enjoyment was to be found in watching things grow, and incidentally, of course, in outdoing one's neighbours.

Our neighbour, Mr. Hayden, has three sons: 
one a year older than Joseph and one a year younger; the eldest, a boy of twenty, whom we have not seen, is away at college. The only little girl in the neighbourhood is Queenie Perth. She lives with her aunt, Miss Wiseman, who takes a wonderful amount of care of her, and talks a great deal about her health. Whenever she plays with' Joseph or the boys at Nestly Heights, however, I notice that she romps as hard as any of them.

The strip of ground that Joseph and I thought possible for our garden lies in the shape of a long triangle, one end of which snuggles up closely to our south veranda. Bordering the longest side of this triangle there is a strip of light woodland, composed mostly of coppice, while both the point and the straight side fit into Mr. Hayden's well-kept land. This straight side, moreover, is outlined by a high wall.

It was not on account of any preconceived plan that our garden plot is so shaped. We perhaps should have preferred a circular or a rectangular garden; but the triangle happened to be the most available bit of ground for planting that our greataunt had left us. Joseph, who has the gift of spying out the advantageous in all things, says that at least we can put the same plants in a triangular plot that we can in any other.

The great decision was about the kind of garden to plant; for we soon became sufficiently modern in the fashion of gardens to feel that it should be 
of some particular type. I remembered that one or two authors recommended Japanese gardens, that others preferred the old-fashioned kind, while one of ambitious talents described gardening on miniature mountains. The more I read, the more I looked askance at our triangular patch, and twice I dreamed of it covered with cabbages; when one day Joseph wisely remarked that we would plant the prettiest flowers, grasses and ferns, and trust to luck to get vegetables to eat. Above all, we should try to make the places where we set out the flowers look like their native homes.

Then a little trouble arose. Whenever, at gatherings in the neighbourhood, our friends discussed the prices of bulbs, seeds and young plants, Joseph's eyes sought mine, and it seemed as if a mist had passed over our imagined garden. We had, in truth, but little money to spend for flowers. But again Joseph wisely said that we could at least go to the woods and fields and get pretty plants, even if we could not afford to buy them of the nurserymen.

One day, still early in March, an old man came to the Six Spruces to sell some bird-houses which he had made when storm-bound during the winter. They were short pieces of the hollowed-out stems of trees, covered with pointed roofs, and given firm floors and open doorways. A bird might well believe that Nature herself had made them. Joseph's delight in these houses so pleased the old man that 
he helped him to hang one from a tree; to swing another from the veranda, and to set the third in a niche of the wall separating the triangle from Nestly Heights. We flattered ourselves then that we were quite in advance of the bird season.

Yet the very next day a bluebird flew with much directness and took possession of the house hung to the tree. It must have been the female bird that slipped in first to see if it pleased her practical mind. She very quickly decided to occupy it for the summer, and when she joined her mate, who sat on the top of the house, she nodded her head and appeared to be telling him all her intended arrangements. Joseph thought that they were also congratulating themselves that their long trip northward was over and that they could now settle down in so cosy a home.

Soon after this we were overtaken by the approach of spring. There was a scent of new earth in the air and the sound of soft winds in the treetops. Winter with its biting cold was being driven away. The bluebirds talked loudly together, and at the point of the triangle where it becomes soft and spongy to the feet we saw a number of long, slender, black birds, very merry and busy with wooing and chatter. Yet the grass that covered the triangle was still colourless; the trees were bare, and the earth under them was strewn with dead leaves. Noticing these things, Little Joseph asked if spring really began in March. 


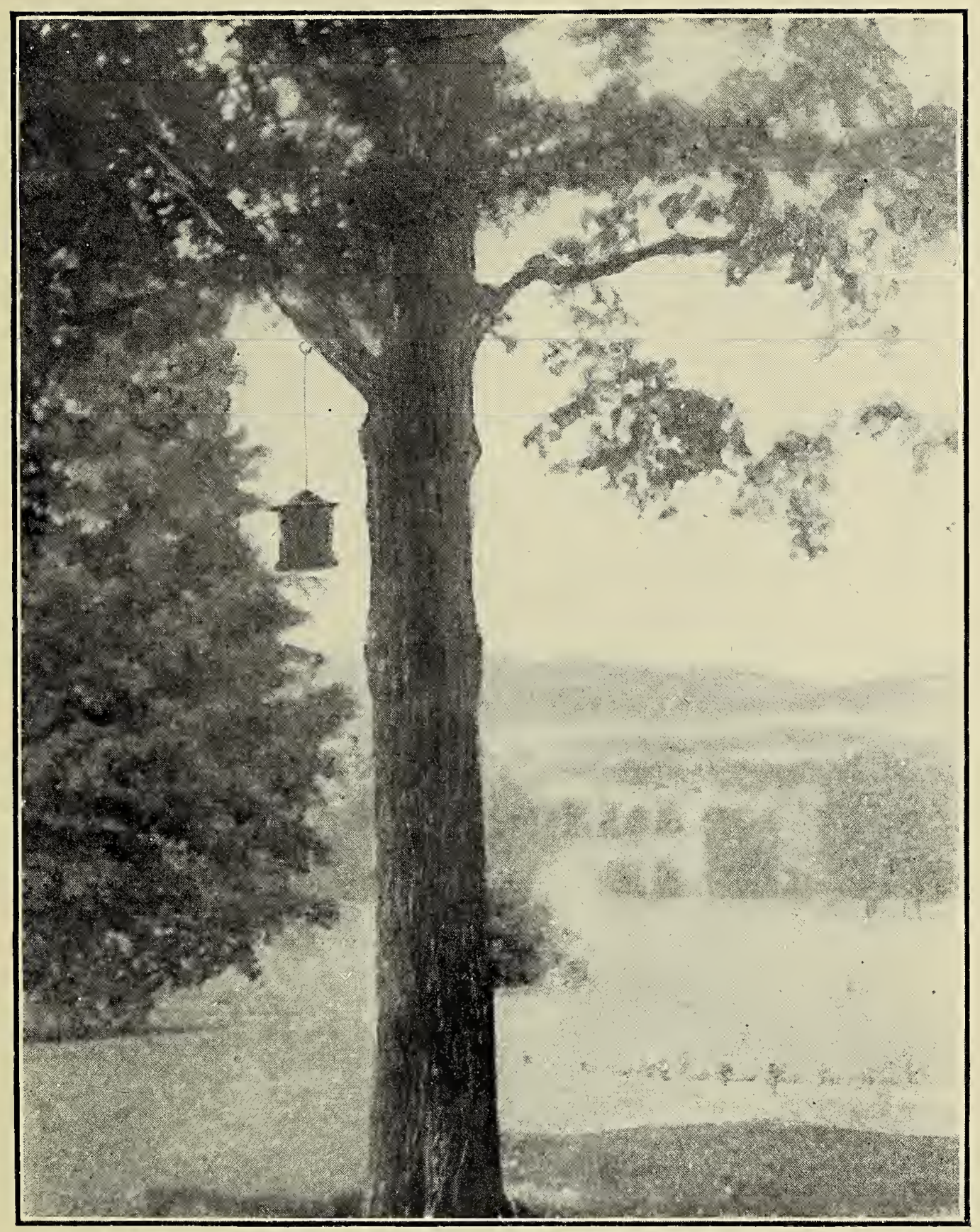

PLATE III.-THE BLUEBIRDS TOOK POSSESSION OF THE HOUSE HUNG TO THE TREE 

On the morrow Joseph awoke early. He was enthusiastic.

"Those long, black birds," he told me at breakfast, "that stay at the lower end of the wood by the triangle are called grackles; and a pair of bluebirds have taken possession of the house in the wall. There is now only one house to let for the summer."

Thus far we had secured our tenants without the slightest exertion.

This same day the man who had made the birdhouses came and asked if he could help us get ready for planting. The back of winter now seemed to be broken, he said. Here indeed was something definite. "The farmers hardly think it is time for ploughing yet," he remarked, and added that there was a good deal of clearing up to be done about the Six Spruces. Further, he told us that his name happened to be Timothy Pennell, and that he took an interest in the place, having sometimes worked on it for our great-aunt. It was he who had told Joseph the long, black birds were called grackles. Timothy seemed to know all about planting turnips and potatoes and beans and a good deal about flowers, although he said he mostly noticed the wild ones that came up of themselves in the woods and swamps.

"We shall plant some wild flowers," Little Joseph told him, "and have others that grow only in gardens." 
"You'll tame the wild ones?" Timothy asked, for he had caught the idea.

Indeed, I began to think that Joseph's simple garden in which wild plants would grow freely and birds build nests might be made as attractive as one where only rare and costly flowers bloomed. We both listened eagerly as the old man related how, when his boy was ill, he had taken hepaticas from the woods and forced them to open before their natural season. He abetted Joseph's scheme of getting flowers and ferns from our own woods and transplanting them in the garden. The number of ideas that soon began to tumble over each other in our minds was astonishing.

It was perhaps unfortunate that Timothy spoke so strongly about weeds. This word shocked us both, since it made us foresee strife and innumerable difficulties. He had said that weeds in a garden were not only probable but necessary to its beauty, and that some of the rankest of them there were handsomer than many hot-house flowers. "A garden without weeds," he declared, "would be like a loaf of bread without salt."

"They will come anyway," Joseph replied, "there is no use in planning for them. What we must think about," he added, and, from the way Little Joseph spoke, the old man must have known that the decision was made, "is how to plant the triangle with real flowers, both tamed and wild." 


\section{CHAPTER II}

\section{EARLY PREPARATIONS}

THE lively way in which the bluebirds continued 1 to build their nests caused Little Joseph and me to think that spring was coming with hasty strides, and that there was not a minute to lose in making preparations to plant the triangle. Joseph had bought some flower seeds with the first money we had set aside for our garden, and his fingers tingled to put them in the ground. We could not, however, induce Timothy to agree that the time for doing so really had come. The old man had a provoking way of looking at the clouds and then dubiously shaking his head. "The farmers are still asleep," he said, "and it is best to follow their movements." From his doubtful expression Little Joseph and I began to fear there might always be frost behind the clouds.

In the meantime the Six Spruces was having such a clearing up as it had not had in years. Timothy assured us that it was better to make the things that were already on the old place look "shipshape" before giving attention to new ones. He 
first borrowed Miss Wiseman's heavy roller and used it on the lawn in front of the house, and the triangle. Then he trimmed the edges of the gravel path that circles the lawn, and raked up all dead leaves and tufts of grass lying about the Six Spruces. He worked very hard over the front lawn, and seemed sorry we had no new ones to make, as he said it was the right time of year for making lawns.

Timothy had a pair of prunıng shears that seemed to give him great delight. They were so large and heavy that I could barely open and close them, although Little Joseph soon learned to use them with ease. When Timothy had finished trimming the lawn borders, he pruned the grapevine with such eagerness that he appeared to be chopping it up for fire-wood.

"I am sure Aunt Amanda never would have allowed him to do that," I said to Joseph, and the old man overheard.

"No, miss," he replied, "but it is just what the vine has needed these many years."

We were really thankful when he left the currant-bushes alone, only remarking that in a day or two he would give them a good spraying with limesulphur. He went next to the blush-rose bush that stands near the south veranda and began clipping. Now I had heard that this rose-bush and the lemon verbena that was planted each year on the other side of the veranda steps were the only flowers in 
the world that Aunt Amanda had really loved. It was pitiful to hear Timothy's sharp scissors going clip, clip every minute. He had always told our great-aunt, he said, how much finer the roses would be if he could have pruned the bush properly. Of course we let him go on.

He did not clip the yellow bell shrub, nor the two spireas that stand near one of the front corners of the house. Neither did he touch the three lilac bushes near the stable. These are the only ornamental shrubs on the place. With a wave of his hand, Timothy said that he would give them all a good spraying before their buds opened.

We had then no outfit for spraying. We decided, however, to buy one, since it would be needed throughcut the blossoming season, and we could not be always borrowing Miss Wiseman's tools. Already Little Joseph and Timothy had cleaned up and sharpened the tools we had found at the Six Spruces; but many of them were now antiquated, although we were glad enough to have them.

After rolling and raking the lawns, clipping the grape-vine and the blush-rose bush, and spraying the cherry-trees, currant-bushes and shrubs, it was astonishing how tidy the old place looked.

When Miss Wiseman came to see us she exclaimed: "Goodness, children, how surprised your Aunt Amanda would have been! You really have given this place a quite different look, and with only 
Timothy Pennell to work a day for you now and then. You have started to make your garden in the best way-by clearing up first."

Of course I told her that Little Joseph was the real gardener, and that he was impatient because not a single grass or flower seed had as yet been planted.

"Make ready first," Miss Wiseman said again, and went away, leaving on the table a beautiful book for Joseph, called "An Ambitious Boy's Garden."

We have both noticed since living at the Six Spruces the beautiful colours of the out-of-door world. Here spring is like a fairy tale. First of all, the grey look of winter fades out of the atmosphere. Then the birds began to chirp, toads croak, and bullfrogs are heard in swampy places. Everything appears to grow slightly pink. The great, bare trees are touched with it, and the grey, dead look vanishes from their twigs. Wherever there are willows, they turn yellow, and can be distinctly recognised among other trees. The red maples that grow in moist places are covered suddenly with tiny red blossoms. Neither Joseph nor I had ever noticed this before.

Near our wood-border there are three red maples which we are now watching grow redder and redder every day. But this red is not, as one might suppose from a distance, just a thick cloud that lights on the trees. It is caused by little blossoms 
that burst out from the twigs, each one being as perfect as if it were a grand lotus lily. When Joseph saw these blossoms for the first time he could scarcely believe his eyes. A day or two ago he asked Mr. Hayden of Nestly Heights if he had noticed how finely our red maples were blossoming.

Mr. Hayden said: "Gracious, they are a splendid sight!"

There is no weeping willow at the Six Spruces. I should very much like one, but those the nurserymen have for sale look very small in comparison with the great ones in this part of the country. Nevertheless, I shall buy one when autumn comes, since Timothy says that is the best time for transplanting them.

It has always been declared by the people of Nestly that the soil at the Six Spruces was rich and well drained, and that flowers would have grown there luxuriously if our great-aunt had desired them. The blush-rose bush was noted for sending out many and perfect flowers each season when, from one year to another, it was neither pruned nor sprayed. It was left instead to grow by the south veranda as unmolested as a wild flower in the woods.

Timothy talks now a great deal about the preparation of the soil since the triangle is to be planted with flowers. Mrs. Keith tells us that it was once our Aunt Amanda's favourite bit of lawn, and was 
the one place where she minded weeds as much as Betsy Trotwood disliked donkeys. Still, Timothy thought necessary to roll it down a number of times, to sprinkle fertilising powder over it, and then to sow it with grass seed. This he did one day after a night of rain, when the earth was moist and therefore ready to take the seed. He lamented that he could not have sown the seeds in late September, since they might then have taken root and had a long sleep during the winter. He said his old head had then no idea that, when spring came, he would be working at the Six Spruces for two children instead of for our great-aunt.

It seems all right for Timothy to call my brother a child and to have his own way in spite of what Joseph says; but I do think he sometimes forgets that I am nearly seventeen.

Naturally, one of the difficulties we shall have with the garden is that no work was done here in the autumn. No preparations were then made for spring. Moreover, at the Six Spruces there are hardly any flowers to reseed themselves. There are none of the kind that come up year after year. Here we found only the blush-rose bush, the yellow bell, the spireas, and the lilacs. Little Joseph realises that this spring the garden is merely to be started. It is likely that we shall have but few flowers, but we hope that with each succeeding year the garden will become more beautiful.

Even if shabby and neglected, the Six Spruces is 
one of the most important places in Nestly, and we have no need to economise space. But just because there is so much room and opportunity for growing flowers, we have decided this first year to make our garden exclusively on and about the triangle. In front of the house we shall only try to improve the lawn. Sometimes we dread lest what we do will not be quite right; but then Joseph says that pretty flowers can never make a place look ugly.

Joseph indeed has his own ideas about flowers. Although he has never before had a garden to work in and to rule, he has often watched the gardens of other people. His love for most flowers is very great, and at the Six Spruces he hopes to see growing the ones that he loves best and to have none that give him no pleasure. Several times he has said: "I do hope you will not ask me to plant petunias." For some reason he seems to think that these flowers mar the look of a garden as much as the appearance of a tree is spoiled by being struck by lightning. If all Joseph's ideas about the garden come true, I think we shall some day have flowers and shrubs rivalling Miss Wiseman's and even those at Nestly Heights. It delights me to imagine how the old place will look when the wall is covered with vines, when flowers of many colours bloom on the triangle, and when others peep from the wood-border.

It has lately turned so cold that Little Joseph has been prevented from working out-of-doors and 
has been busy making window-boxes in which to start seeds. These boxes are not pretty, but Miss Wiseman says they are ingenious. She always calls Joseph "Master," instead of "Little," which makes him feel very grown-up in her presence.

To begin with, Joseph cut down some old soap boxes to about two and a half or three inches in height, and then filled them with some of the rich earth that lies all through our woods under the dead leaves. He intended to place them in the library window, where the sun would shine brightly upon them. But, even so, he was not quite satisfied. At Miss Wiseman's he saw the gardeners starting their seeds in glass houses, and this filled him with alarm lest they should sprout long before his own.

One day in a dark closet he found a high pile of my camera plates which unhappily had been failures. He washed them off with hot water and soda, and soon had a number of neat pieces of clean glass five inches by seven in size. With strong gum he then pasted several of them together on strips of cloth until he had three lengths of glass as long as the boxes. He intended to cover the seeds with them when they were sown, and to hold them up with little prop-sticks whenever he wished to admit the air. Of course such covers were wabbly and difficult to handle; but Little Joseph did not mind this. He would now be able to have some of his seeds under glass. 


\section{CHAPTER III}

THE FIRST PLANTING

$\mathbb{M}^{\mathrm{Y} \text { way of helping Joseph in these March days }}$ I have written to a number of nurserymen for catalogues, which, after much reading and pondering over, have helped us to decide on the seeds for our garden. Many of the names in these catalogues we had never heard before. It would be fun, we thought, to buy all the seeds mentioned and then to find out for ourselves what kind of flowers they would turn into; but this we did not venture to do, since we wished first to be sure of having some of our old friends in the garden.

We chose ten-weeks stocks, baby's breath and cardinal-flowers to start in the boxes, and bought numbers of other seeds to sow out-of-doors as soon as the frost left the ground. Almost every day Little Joseph looks over these seed packages, reading anew their labels and thinking how wonderful it will be when through his care they turn into pretty flowers of different forms and colours.

I helped him sow the seeds in the boxes. It was 
the easiest work of all. We first passed the top soil through a sieve, in order that it might be fine and free from lumps. Then with a pointed stick we made little furrows, dropped in the seeds, and drew the soil over them, patting it down evenly with a ruler. The furrows for the baby's breath, which we planted in a box by itself, were about an eighth of an inch deep, and those for the ten-weeks stocks which filled the second box were made a full quarter of an inch in depth. Mrs. Keith, who seems to know as much as Timothy about planting seeds, told Joseph that such matters as these were most important. The very small seeds of the cardinal-flowers in the third box were simply sprinkled over the surface of the soil and then pressed down lightly.

It was most fascinating to handle these little seeds, which looked as though they had no life at all in them; and to know that they will certainly turn into real flowers. When Joseph gave them water, I felt that their thirst was being quenched and that they would begin at once to soften and grow. Of course Joseph could have wet them with the rose sprayer, but thought it safer to submerge the boxes in a large tub of water, since the small seeds, especially those of the cardinal-flowers, were not so likely to become dislodged.

The seeds that we did not use in the boxes Little Joseph put carefully away in their packages. Later on they might be sown out-of-doors. Mrs. Keith 
bound some green paper muslin around the outside of the trays after they had been placed in the sunny library window, and we all quite ceased to think that they were only ugly soap boxes filled with deadlooking seeds. We already imagined the little plants shooting up through the earth.

Joseph said it was too bad to have made three boxes and three glass covers for but three kinds of flowers. I told him, however, that I would rather have a good many flowers of one kind early in the year, than to have only a few later of a great many kinds.

Little Joseph knew as I did that it was not necessary to plant the baby's breath, the ten-weeks stocks or the cardinal-flowers indoors. We could have waited and sown them in the open when the frost had left the ground. But Little Joseph's fingers and mine also were tingling to plant something. We could not wait with patience until the farmers began to plough. The window-boxes made us feel that some things were already started. In fact, they were our first experiments. Joseph was pleased besides to think that he had done something which was not mentioned in "An Ambitious Boy's Garden." That boy had not a bit of glass on his place as large as a camera plate. But then this was not the first year that he had had a garden.

The closet that Little Joseph uses for his tools, seeds and spraying outfit is in the hall opening on the south veranda. It is a convenient place, since, 
when it is warm, he can do his hammering and other work on the veranda. While working he can also watch the bluebirds make their nests. $\mathrm{He}$ notices that they are very clever at this building. In fact, Joseph says he would rather try to build a man's house than the nest of a little bird.

There is another closet in the library which Joseph has taken possession of for his magazines and catalogues. These latter are coming now by almost every post. The nurserymen have somehow found out that Joseph is one of the heirs of the Six Spruces and many of them attach "Esquire" to his name. This makes my calling him "Little Joseph" seem very familiar, and even Miss Wiseman's "Master Joseph" sounds too unimportant. The shelf in the bookcase that he has cleared for his garden books has as yet but one occupant. This, of course, is "An Ambitious Boy's Garden."

Lately we have been so busy getting ready to make our garden that I have said nothing about the wrens that have settled in the house, swung from the veranda. Timothy says they have come earlier than usual this year, and thinks the spring may follow their lead. Nothing was pressing to-day, so Joseph tried to discover how nearly they had completed their nest.

He was surprised to find that they had made a blockade in front of the doorway to their house. He pushed his finger through the small opening in the house until it touched a heap of fine, smooth 
sticks so interwoven that they were almost as resisting as a stone wall. By it the doorway appeared quite closed. Joseph wondered how the wrens ever went in and out. He had watched them so often since they moved into the house that they had wisely made up their minds he meant to do them no harm. He was now hoping that one or the other would go in or come out, so that he might see how they managed to slip through the blockade.

Suddenly then the female bird flew towards the house. She slipped in without apparently waiting a minute to think how she would enter. It almost appeared as though she went through the barricade. Little Joseph was quick enough, however, to see that from the bottom of the doorway her flight slanted upward to where a tiny space had been left free. Indeed, the little wrens had been clever enough to block completely the doorway at the bottom and to let the nest slant back a little from the top, thus leaving the space to slip in by an upward line of flight.

Only a little bird knows how to build in that way, Joseph thought, when out she flew so quickly that he could not see where she went. When she returned she had another tiny twig in her mouth. So the nest is not yet finished, Joseph mused, and wondered if they were fastening things up tighter to keep him out. He then remembered that birds had other enemies besides boys, for, only a day after the wrens had come to the house, a pair of 
bluebirds had tried to drive them away. Although the wrens were the smaller, they had fought very hard to keep their home, and, after a battle that lasted two days, the bluebirds had left them in peace.

No doubt Little Joseph would have paid a visit to the bluebirds and also to the grackles, had I not gone to tell him that Queenie Perth had come with a note from Miss Wiseman asking us there for luncheon.

At first Joseph shook his head, saying he had far too many things to attend to at home to spend nearly a whole day visiting. I reminded him that Timothy had not come to help him, and just then Queenie ran out and joined us. Joseph very quickly said we would go to Miss Wiseman's. He then showed Queenie the bird-houses and told her about their occupants. He would not let her go as close to them as he did because, he said, the birds were not accustomed to her.

"Birds like me very much, and butterflies, too," Queenie told him. "Down at Auntie's they are no more afraid of me than your birds are of you."

She ran home after this, since she had to carry the message back to Miss Wiseman.

Little Joseph then spent the rest of the morning raking up the dried leaves and dead twigs that were lying in the coppice by the longest side of the triangle. The earth had begun to feel slightly moist, and we wondered if the frost was not now nearly 
out of the ground. The air, however, was still chilly. As Joseph gradually raked down by the boggy point of the triangle he saw that the pussywillow shrubs were nearly covered with soft grey catkins. They had grown a great deal since the last time he looked at them, and were the largest pussy-willows he had ever seen. This was because no one had picked from or marred the bushes for many years. In this quiet corner of Nestly they had grown stronger and lustier every season.

Our Aunt Amanda had not cared for flowers, except the blush-rose bush and the lemon verbena; neither had she cared for people, and surely no one would have ventured into her place to pick or to destroy anything. These pussy-willows looked different from the thin, little twigs and small catkins that we had seen by the side of the public roadway. They, poor things, stand where any one may pluck them. After a few more years they will perhaps grow tired of blooming for no better purpose and will give up altogether.

Joseph was extremely cheerful at having such fine pussy-willows at the Six Spruces. He thought they could not have more perfect ones even at Nestly Heights. I knew then that Joseph was touched by the spirit of rivalry which lies hidden in all gardeners. 


\section{CHAPTER IV}

\section{MISS WISEMAN'S SUGGESTIONS}

S we drove through Miss Wiseman's gateway
"Surely there are flowers in bloom, see there, every-
where!"

This was true. Little baby snowdrops were lifting their heads and blooming in many places. Some of them were only in bud, but they also made a white gleam through the grass.

"I wonder that no one reminded us about snowdrops," I said. "We might have set out a few through our own lawn."

"Their bulbs have to be planted in the autumn," Joseph replied, "and last autumn we were not the owners of the Six Spruces."

"You must just enjoy my snowdrops and crocuses and Siberian squills this year," Miss Wiseman said, when we spoke to her about them, "and next spring you can have your own. This is the first day," she added, "that they have made much of a showing. These little snowdrops come first of all. In a fortnight larger ones will be in bloom, while the 
crocuses and squills will soon make the ground look as gay as a carnival."

"Will they also come up through the lawn, or be in beds by themselves?" I asked.

"Oh, through the lawn," Miss Wiseman answered. "We make believe they come up by themselves at random, instead of having to be planted in the autumn with an English bulb planter. But next autumn will be time enough for you to attend to that matter, while to-day I have a surprise for you."

We followed Miss Wiseman to a part of her grounds where a great deal of shrubbery grew. Two men were busy taking up bushes from some places and planting them over again in others.

"You see I am thinning out my shrubs," she said, "they grow at a rate we think little about in the first ardour of planting. I have now more than I can take care of, so to-morrow, Master Joseph, some are to go over to the Six Spruces."

Master Joseph was delighted. He had been wishing that we might have more shrubs at the Six Spruces than just the one yellow bell, the two spireas and the three lilacs. He and Queenie at once ran to ask the men to tag the shrubs with their names, that he might later read about them in "An Ambitious Boy's Garden."

After we had lunched and had seen the other changes Miss Wiseman was making in order that her place might be more beautiful this year than 
ever, Little Joseph wondered if people ever really find out how to make a perfect garden. Until today he thought that Miss Wiseman had learned it long ago like a lesson. She always spoke with decision, and as though there was only one way in the world of doing things. To-day, however, she continually pointed out to us the changes she intended to make. The year before, she told us, she had noticed that colours of certain plants did not look well side by side, and that some had outgrown others and left ugly gaps in the top line.

All this time Little Joseph was learning important things. Now, whenever he sows seeds, he will think about the colours of the blossoms, and how each will look beside its neighbour. He will remember, also, not to plant flowers that are very small by the side of those that are very large. He thinks it will be a good plan to keep a little diary of the things he should and should not do.

Queenie did not like to stay in the garden, nor did she wish to talk about it. "Summer is not here," she said, "the butterflies have not come." She loved the butterflies and often ran and played with them. The flowers, of course, could not follow her as she dodged and sprang lightly from place to place. Indeed, Queenie Perth reminded me of a butterfly herself. She was not exactly a shy child, yet, when one attempted to catch or to caress her, she sprang away and ran about playing little games which only she understood. 


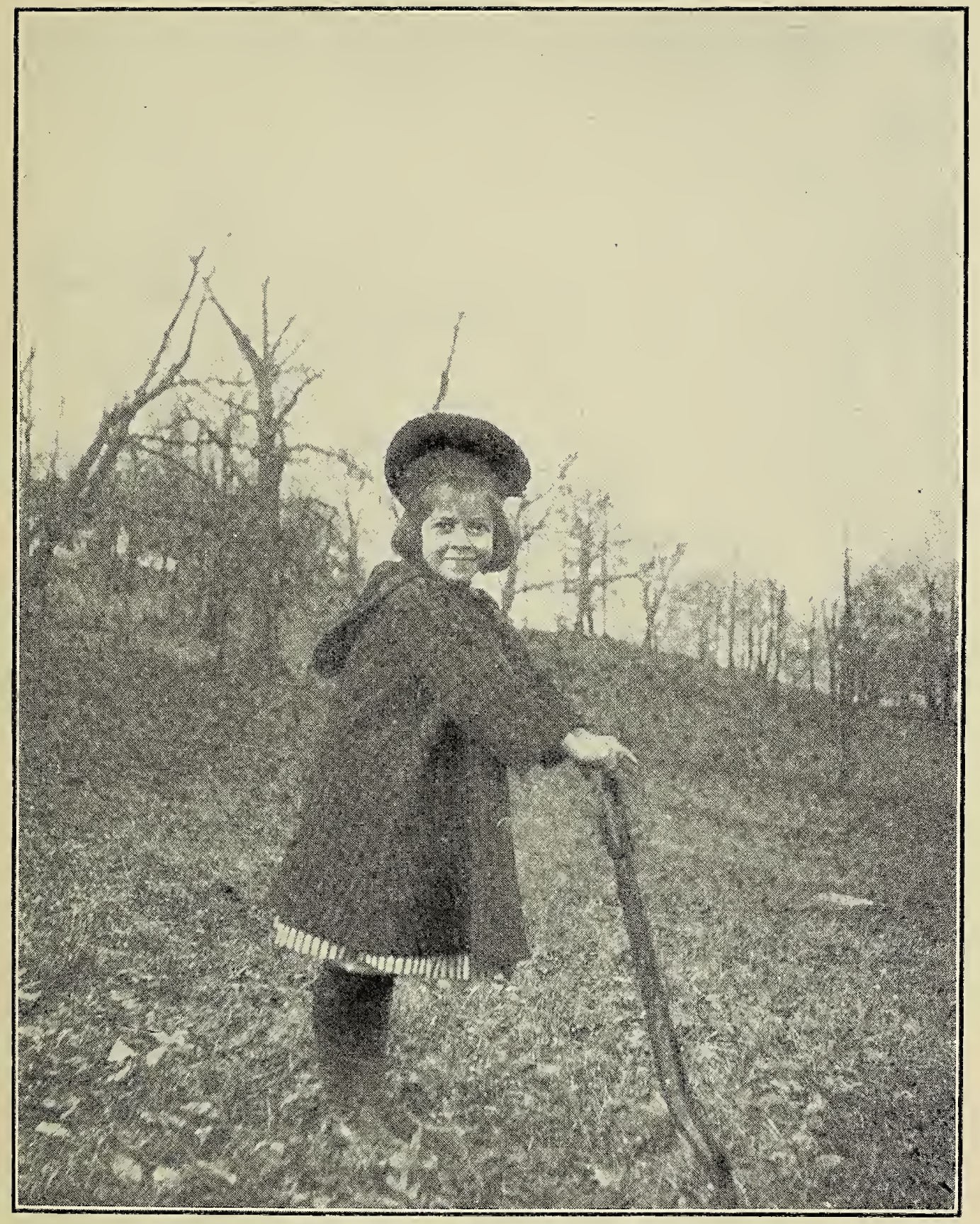

PLATE IV.— "SUMMER IS NOT HERE" 

At another part of Miss Wiseman's place, Joseph saw that the men had dug a deep trench and that seed packages were lying near it on the ground. He had heard of no seeds being planted out-ofdoors as yet, so he thought they must be grass seed, and he wondered if the grass would come up and turn green by the time the birds had finished their nests. He did not like to appear ignorant about such things before Mr. Bradley, the head gardener, so he said very jauntily:

"It's just the right time to plant grass seed."

"Is it?" Mr. Bradley replied. "We were thinking it was the season for putting in sweet peas."

Then Little Joseph asked a great many questions: why Mr. Bradley dug the trench two feet deep-for it seemed to him that the plants would have to climb a long way before getting out of the earth-and why he had turned the sods taken from the top of the trench upside down, laid them at its bottom, and then spread them over with manure.

"That is rotted cow's manure," Mr. Bradley answered. "It settles down after it has been wet, and makes the earth rich for the roots to sink into." Joseph then saw the men fill the trench nearly to the top with a rich-looking soil made of old manure, garden loam, and earth from the woods. He saw them pat it down firmly. They then made a furrow for the seeds about six inches deep, and planted them an inch apart. Mr. Bradley told 


\section{MISS WISEMAN'S SUGGESTIONS}

Joseph to notice these things, since they were of great importance.

As the seeds were covered up with only about two inches of soil, Joseph asked what was to be done with the rest of the earth lying by the side of the seed-row.

"That," Mr. Bradley answered, "will later be drawn in to cover the plants partly when they have shot up to the length of my thumb; and as they continue to grow the soil will be used in this way until the furrow is filled. It is likely that we shall give it a good watering about twice a week."

After the newly sown seeds were watered, $\mathrm{Mr}$. Bradley said things were pretty well looked after for the present. Joseph then asked when the sweet peas would be in bloom and what would be the colour of their flowers. He had other questions on the tip of his tongue when Mr. Bradley said:

"My lad, those flowers will be in bloom about two months from now - that is, if we watch them well, water them and cultivate them. You see these strong posts we have driven into the earth? Later we will cover them with wire in order that the sweet peas may have a suitable place on which to climb."

This all seemed very wonderful to Little Joseph, who told Mr. Bradley that he wished he had bought more sweet peas and less grass seed.

"No need of wishing that," Mr. Bradley answered heartily. "We have more here than we 
shall use this year, and the grass seed will always come in handy."

He then gave Joseph several packages of sweet pea seeds, white, blue, red, lavender, green and pink. Mr. Bradley was a fashionable gardener as well as a wise one, and knew that sweet peas of one colour make prettier bouquets than when various kinds are mixed together. While assorted seeds cost a little more than mixed ones, considerable time was saved later in picking the flowers.

Joseph's pockets stuck out on both sides when he returned to the house, and he had naturally a great deal to say about what he intended doing at the Six Spruces. First of all, it was necessary for us to decide where we should plant our sweet peas. We could not put them on the triangle itself, and they were not suitable for flower-beds or borders. The boggy corner would not do, since there the soil was too moist, and the side by the wood-border was far too shady a place. Mr. Bradley had told Joseph that they needed plenty of sunshine.

"Perhaps we can plant them along the wall that separates the triangle from Nestly Heights," Little Joseph said. "The sun can peep at them there and the wall will be good for them to lean against when they begin to climb."

We believed we had decided the matter, when Miss Wiseman returned from where she had been looking for a catalogue, and naturally had something to say about planting sweet peas. 
"It will never do to plant them by the stone wall," she said at once. "They need light on both sides, and it is best to have them running from east to west. Now if you had a rail fence-_"

"But we have not," Little Joseph replied mournfully. He had begun to feel very disturbed about the sweet peas.

"Then the best thing you can do, Master Joseph, is to set about and build a wire trellis. If I were a boy, I would help you," Miss Wiseman said, in a way that made Little Joseph think it must be no end of fun to build a trellis. "You can make it any shape you like and place it wherever you like. You just set posts in the ground and fasten your wire around them. At least that is the way I manage to accommodate my sweet peas."

I hastened to say that her flowers were very beautiful, for Miss Wiseman is as sensitive about them as many mothers are about their children.

Here then was a new idea for Joseph. He not only had to dig a trench and to plant his sweet peas, but to build a trellis for them to grow upon.

"I seldom hasten things as much as Mr. Bradley does," Miss Wiseman said. "If I were you, I should not put in the seeds for a week or ten days."

"But the wrens have their nest nearly built," Little Joseph replied. "Spring will soon grow warm, and we shall have no flowers."

"It is just because the wrens have their nest ready that they can keep warm when the late frost 


\section{MISS WISEMAN'S SUGGESTIONS}

comes; but there is no place for a flower to snuggle into when it unfolds before the weather is settled. You set about the trellis to-morrow, Master Joseph, and plant the seeds when it is finished. Your flowers will be here soon enough."

We both felt that about this, as about everything else, Miss Wiseman must be quite right.

After we had returned home, Little Joseph and I walked down by the six spruces. They were moving very gently in the breeze, and had the solemn look that always comes over them when the sun begins to sink in the west. Underneath them, the ground was a mat of needles, and they had still the dull brownish look which they assume in the winter. Little Joseph said that, if we had some seats and a table within their circle, we should have a real summer-house where there would always be a breeze. We wondered if Timothy, who had made the bird-houses so well, would not help with the trellis and furniture for the summer-house.

The six spruces began to wave their branches more strongly: the sun dropped quite out of sight. We then went into the house, Little Joseph thinking of the many things he had to do on the morrow. 


\section{CHAPTER V}

\section{'A DAY'S HARD WORK}

A LTHOUGH Timothy came early the next A morning, Little Joseph was already up and astir with several new ideas in his head gathered the night before from "An Ambitious Boy's Garden." First of all, he determined to settle the inatter of the trellis for the sweet peas. As they would not bloom until two months after the seeds were put in the ground, he thought the bare posts with wire stretched on them would look very ugly awaiting them all that time. We, therefore, decided to plant our sweet peas along the upper side of the plot where the clothes-posts stand. They would then be near enough the house for us to see them often and to enjoy their delicate scent. At Miss Wiseman's, they are far away from the house in what she calls her picking garden. Before breakfast, Joseph and the old man had set about making a strong but simple trellis.

It took them some time to drive the posts firmly into the ground, and to think out the exact way in which they would manage the wire. It ran from 


\section{A DAY'S HARD WORK}

east to west, the exposure Miss Wiseman had so strongly advised, and it was in two sections, each being placed at right angles to the square of the clothes-posts, so that these sections appeared to form the borders of a little path.

When the trellis was well along, I told Joseph that it looked strong and new, but not exactly pretty.

"It is not yet finished," he replied, "we are going to paint the posts green."

While helping Timothy build this trellis, Joseph learned the knack of swinging a hammer. When he first began to drive nails into the window-boxes, they entered the wood much as they pleased, and twice he bruised his fingers. His birthday was now not far off, and I thought that I would give him a box of carpenter's tools instead of the baseball bat I had had in mind.

Just as the last nail was being driven into the trellis, and Joseph and the old man stood viewing their work, a wheelbarrow full of shrubs came over from Miss Wiseman's. The plants were not much to look at, being then entirely without leaves, and we could not even imagine what blossoms would do for them. To us, one bare twig had an appearance very like another. Still they were tagged as Mr. Bradley had promised, but with names that neither we nor Timothy had ever heard before. Timothy looked at them most carefully.

"This one has reddish twigs," he said, "see how 
different it is from the others. I am thinking it must be the red-twigged dogwood."

"The twigs of this one look reddish underneath, while above they are covered with a greenish-brown roughness," I said.

"Then it is likely to be that old-fashioned sweet syringa that has flowers as smooth and white as wax," the old man told us.

"These twigs look yellower."

"Likely another yellow, or golden bell, the same as the one by the west corner of the house;" Timothy said.

"And this one?" I asked, for he seemed to be able to tell by the twigs the names of the shrubs.

"It may be called Deutzia," he answered. "You notice it is not very tall. Most likely it will bear white flowers. These three are the bridal-wreath, and these two are hydrangeas," he continued. "I feel doubtful about this large tree-like one here, but, if I am not mistaken, it will turn out to be the smoke-bush."

"If that means smoke-bush, you are right," said Little Joseph, and he held up the small labelled bit of wood he had found tied to the shrub. The old man nodded his head.

"So that is what those smart gardeners call it," he said.

I then looked at the label and it read rhus cotinus, which we found out later was the scientific name for the smoke-bush. 
"It is a fine"collection," the old man commented. "The yellow bell will bloom along with your own in April, the spireas will be like brides in June, and that little Deutzia will be coming on in July. The smoke-bush will be all feathery in August, and for September you have the hydrangeas lasting until frost."

"But May has been skipped," Little Joseph said.

"Indeed, then, you have the dogwood," Timothy answered briskly, "and your own three lilacs, which did your Aunt Amanda every year as long as I can remember. It is October that has been skipped, and for that month I will bring you myself as fine and odd-mannered a shrub as any of these-just one of our own wild ones from the woods."

While we were looking at the shrubs, I had grown quite chilly, for the sun had gone under the clouds and a piercing east wind was blowing. It was one of the days when March makes believe that spring has moved very far off. Little Joseph also was tired from his work on the trellis and from looking over the shrubs, and Timothy said he would take care of them until later in the day when we should all attend to their planting. Joseph and I then went into the house for luncheon.

Afterwards, he took out "An Ambitious Boy's Garden." The book, however, had not a word in it about shrubs. It was all about flowers.

"It is fortunate that we have shrubs," Little Joseph said, "for, although we shall not plant them 
on the triangle, they will give the Six Spruces a very gay look."

We then began to think where we should plant the shrubs, and this led to my getting a pad and pencil and drawing a small plan of the triangle, the paths between it and the veranda, and the circle in front of the house.

It was easy enough to dispose of the yellow bell, for we both thought it should go near the one which stood by the corner of the west veranda. The old-fashioned syringa I wished to plant just outside the dining-room window. I remembered the sweet scent of its waxen flowers, and thought in that position it would be near to us. The hydrangeas were more difficult to decide about, but we concluded to put them at the bottom of the circle, slightly following its curve. They were even now tall shrubs.

Joseph thought one of the spireas would look pretty between the south veranda steps and the wall, and we marked a place for it there on the plan. The other we planted by the long drive bordered by spruces that leads out of the front gate. The smoke-bush we placed rather near the house on the side where the triangle is bordered by the wood. Only the Deutzia and the red-twigged dogwood then remained, and, as neither of us knew how they looked in bloom, we left their placing to Timothy.

When once Little Joseph begins a thing, it is very difficult for him to leave before it is finished. 
His head this afternoon was full of going to town to buy paint, that he might continue work on the trellis. At length, I persuaded him to leave that entirely to Timothy and to occupy himself with drawing designs for planting our flower-seeds. Any day, I said, the spring might surprise us by growing very warm, and I especially wished him to make up his mind where we should have roses.

"The smell of paint," I said, "makes me very sick, and I have heard of boys having painter's colic as well as girls."

Little Joseph then wondered if this smell might not disturb the sweet pea seeds, but soon concluded that they would know nothing about it, as they would be well covered up with earth. From the window we could see the old man busy digging the trench before the trellis.

"To-morrow," Little Joseph said, "he must go somewhere else to work, so he is doing as much as he can to-day."

When he had finished digging and had put the overturned sods and the manure in the bottom of the trench, and had filled it nearly to the top with earth, Joseph went out with his sweet peas. He placed each little seed on the soft earth himself, remembering all that $\mathrm{Mr}$. Bradley had told him, and lightly covered them over with soil. Later, Timothy showed Joseph about putting on the hose. The water trickled gently down to the seeds and settled them into the soft earth. The planting 
of the sweet peas had been very simple, but when Little Joseph had first seen Mr. Bradley and his men at work, he had wondered if he ever would be able to put the seeds in the ground in just the right way.

Later in the afternoon we helped Timothy plant the shrubs. He had already dug holes in the places we had chosen, and we held the shrubs straight while he shovelled in and packed the earth about their roots. They too were given a good soaking. The Deutzia was set in front of the house and the red-twigged dogwood at the edge of the woodborder, opposite the middle of the triangle.

"It will feel at home there," Timothy said, "for many of its relatives are in the woods."

At first Joseph could not follow Timothy when he talked about the relatives of plants. He thought relatives meant parents or people like our greataunt. Afterwards he found out from "An Ambitious Boy's Garden" that plants are divided into great tribes and families. This interested him extremely, and now he seldom hears of a plant without wondering to what tribe it belongs, what family, and then what kind of a member it is in that family. All plants, it seems, are not good and lovable any more than all boys are wise and useful.

It was after five o'clock when the last shrub was planted, and Little Joseph's hands were red with the cold. He went into the house, and, after considerable scrubbing and dressing, he appeared 


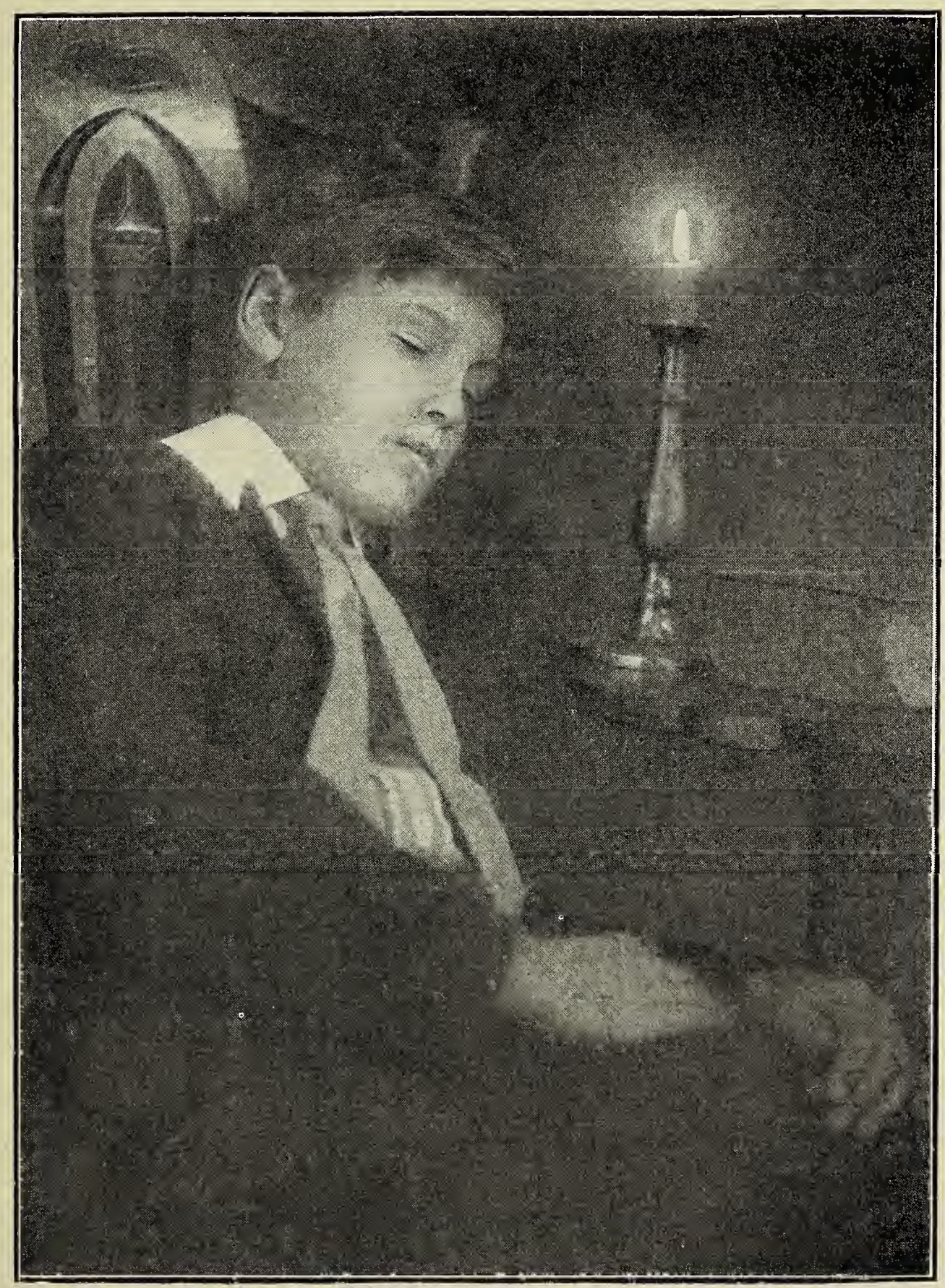

PLATE V.-HE SLEPT WITHOUT ROCKING 

transformed from a young gardener to a small gentleman.

"The trellis is built," he said while we were at dinner, "the sweet peas are planted, the shrubs are set, the old place has been cleaned up, and some seeds have been sown in the window-boxes. It is only the twentieth of March and, as the wrens have not yet finished building their nest, I think we are keeping up with them pretty well."”

Almost before Little Joseph had finished speaking, and long before he was through with his dinner, I noticed that his eyelids slipped down often over his eyes. His work in the open had caused the "sandman" to come unusually early. "An Ambitious Boy's Garden" was not even opened after dinner, and, as our Aunt Amanda would have said, he slept without rocking. 


\title{
CHAPTER VI
}

\author{
'JOSEPH DOES SOME TRANSPLANTING
}

SEVERAL days passed before Timothy came to $S$ work for us again. The weather continued chilly and damp, although each time that the sun peeped out and lingered on certain spots, it seemed warmer than the time before. Over at Miss Wiseman's the snowdrops have been joined by hundreds or even thousands of Siberian squills tossing little blue flowers through the grass, while in their neighbourhood there are many crocuses of bright yellow which appear to play at being laughing spots on the emerald grass. Some of the snowdrops, I noticed, even began to fade and to hasten out of sight before the sun had a good chance to warm them. It appears that they really love March with its cold air and winds.

Little Joseph still regrets that we have none of these flowers to cheer up the Six Spruces and help us say good-bye to winter. He enjoys seeing them at Miss Wiseman's and at Nestly Heights, but this kind of enjoyment is quite different from the pleasure of having them yourself. In his note-book, he 
has written down the names of the bulbs we shall plant the coming autumn so that next spring the Six Spruces will appear less desolate.

For the last day or two, our attention has been given to the wood-border facing the triangle on its long east side; and there this morning we had a surprise. Joseph found some flowers blooming as gaily as those on Miss Wiseman's lawn. They were hepaticas standing up jauntily among their rusty-looking leaves, having taken the precaution to cover their stems thickly with silky fuzz that they might keep warm despite the variable moods of March. These stems are as yet, however, very short. On one plant the little unfolded flowers were all lavender, while on another they were white. Joseph found none that were pink. Indeed it had been rather hard to find these flowers in the woods. They cannot be seen plainly as can the crocuses and snowdrops and squills. But when they were found and looked at closely they appeared just as sweet. The unfolded ones were in the sunny spots of the woods. It seemed as if they had just jumped into the passing footprints of Jack Frost.

At once, Joseph had the idea to transplant some of them to the very edge of the wood-border, where they might be seen from the path separating it from the triangle. He remembered all that Timothy had told him about having once forced some hepaticas to bloom when his son was ill. Little Joseph therefore set about this work very methodically. 
He first staked out fifteen places where the woodborder slopes slightly towards the path. There was no regularity in the design he made, although he set his stakes to cover a space greater in length than in width. Then he dug fifteen holes, picking out the stones and rough clumps of earth. Afterwards, Joseph took his spade and shoved it into the earth to its full depth at the four sides of each plant, and lifted it up so carefully that it did not realise it was being moved from its home. One by one he slipped them from the spade into the holes, filling up any remaining space with earth. At length, when fifteen of the lustiest ones he could find had been transplanted, he watered them freely.

When Joseph told me what he was about to do, I felt sorry. My imagination connected hepaticas with the woods. I thought they would surely lose their wild charm if placed near a garden where poppies and pansies bloomed. But when he showed me where he had set them along the wood-border, and that they were still under the protection of the great trees, I changed my mind and was delighted with his work. Like the snowdrops, these little flowers are not afraid of March.

"Even after their blossoms are gone," Joseph said, "their leaves will look pretty here. See how they lean upon the earth."

I told him that these leaves had not come up with the spring, but were those of last year which had remained strong and green throughout the winter. 
"Later," I said, "this year's leaves will unfold."

More than ever, then, was Joseph pleased with the thought that he had set out fifteen plants which bear flowers as early as the snowdrops, and whose foliage keeps green even when the earth itself appears dead.

We were both a little disturbed later in the day when Mr. Hayden of Nestly Heights came to see us and said he remembered having heard his son, Percy, explain that those particular little wild flowers should be transplanted in August in order to establish a permanent colony which would continue from year to year. Little Joseph hastened to tell him that he had transplanted them with such large blocks of earth that they could not have felt being moved at all. Mr. Hayden himself saw that they were set in the same kind of soil, and amid the surroundings of their original home.

"Well," Mr. Hayden said, "see how the plan works. This is your first year at gardening and is the time for experimenting. Over at the Heights; our gardeners are so experienced, and have such cutand-dried rules about everything, that I seldom venture to pick off a dried leaf, fearing I may do it out of season. My son, Percy, however, has dabbled in wild gardening and, when he comes home for his Easter holiday, he will tell you more things than you will be able to jot down in twenty note-books." It was Little Joseph's note-book that had amused Mr. Hayden so greatly. 


\section{JOSEPH DOES TRANSPLANTING}

Mr. Hayden is a very large man, and his way of speaking reminds me of the blowing of the wind. There appears to be always a strong current of air about him, although Joseph has noticed that he is never cold. We have heard that Mr. Hayden is very proud of his eldest son, who will soon be home from college. He says that Ben and Harry are both fat and lazy, and that he will have to send them out West as cowboys to get some sense knocked into their heads. But even Joseph has learned not to take Mr. Hayden quite seriously.

We both know, however, that the boys at Nestly Heights seldom go into the gardens and that, when they do, the gardeners invariably complain about them. The boys think gardening stupid and have been amazed at Joseph's interest in his seeds and planting.

"We never sow or plant here," Ben told him. "Our flowers come up by themselves."

Joseph concluded that he must be sadly ignorant about flowers, and ceased to talk with him on the subject.

While Mr. Hayden was walking with us at the Six Spruces, and Joseph was telling him some of his ideas about the vines he intended to plant along the wall which separates our place from his own, Timothy came with a straggly, unattractive shrub which he wished to set out. It was a present from himself. Of course, Joseph and I knew it must be the "queer one" he had told us would 
bloom in October and November. As it lay on the wheelbarrow it looked to be five feet tall. There was no vivid colour showing in its bark, and as it was bare of leaves I wondered how the sun and the summer would transform it.

"It is the native witch-hazel," Timothy said, "and the best way to learn about it is to set it out here and let it grow until near winter-time, when it will begin to flower."

Mr. Hayden said he had no witch-hazel on his place, although the shrub had been a favourite of his as a boy when he had lived farther north. He thought in fact that witch-hazel needed to grow in a colder climate than that of Nestly.

"They may not come around here much of themselves," Timothy replied, "but, when they are planted, they thrive almost like weeds, only a bit more slowly." He had bought the one he gave us from a nurseryman on the outskirts of the town. It was in truth through his interest and that of Miss Wiseman that the Six Spruces would be likely to have a shrub in bloom every month from April until November.

Timothy planted the witch-hazel at the edge of the wood, not very far from the dogwood, but more snuggled in among the trees.

"It will not bloom," he told Joseph, "until these trees have had their flowers and leaves and fruits, and dropped them all to the earth."

"This coppice creeping down near your triangle 
gives an excellent opportunity for planting wild Howers and ferns," said Mr. Hayden.

"And that point where the triangle is so moist is for marsh plants," Joseph explained. "And the wall separating the Six Spruces from Nestly Heights is for climbers."

"My boy will be one of them when he comes home. Eh!"

Mr. Hayden then winked at me and gave one of his great laughs that seemed enough like the wind to make the bare twigs tremble.

"At the Heights to-day the men are planting hardy roses," Mr. Hayden continued. "We pride ourselves on our roses. I declare we do."

Then he told Joseph to go with him and see if his men had not a few to send over to the Spruces.

"Perhaps you don't think so, my boy," he said to Joseph, "but I know your sister believes there is no flower so beautiful as the rose."

Joseph followed Mr. Hayden, and for a while I wandered about the Six Spruces by myself. March was nearly over, but summer and its radiant flowers still seemed a long way off. I wondered a little if Aunt Amanda would have been pleased at our doings in her old home. She had been a severely minded woman, and had disliked Mr. Hayden because he invariably referred to the place as the Spruces, instead of the Six Spruces. I wondered about Mr. Hayden's son who knew wild flowers and ferns, and would join the vines in climbing the 


\section{JOSEPH DOES TRANSPLANTING 47}

wall. Indeed, I was thinking about many things when I noticed that one of the bluebirds that had perhaps been watching my movements flew into the house with a worm in his mouth.

"It is the male bird," I thought, "taking food to his mate. The nest must be finished. Perhaps she has laid an egg and is now snuggling it under her wing." Shortly the male bird flew out of the house and darted away. I remained quite still, and, in about three minutes, he returned with another morsel in his mouth. Then I felt convinced that at least one egg had been laid, and that the little wife was having her evening meal. 


\section{CHAPTER VII}

\section{MAKING THE SEED AND FLOWER BEDS}

OW that the farmers have begun to plough,
and the neighbours and Timothy have decided that the frost has disappeared, Little Joseph is making ready to sow the seeds he has bought. This making ready seems to play a very large part in gardening. First of all, with Timothy's help, he has made what he calls a seed-bed. This is some distance from the garden, and is only a place where seeds are to be sown and allowed to grow for a little while. For just as soon as the plants have become the right size, they are taken away from the seed-bed and transplanted into the real garden. From Miss Wiseman, Joseph learned that a seed-bed is a very wise thing for every boy and girl to have who thinks of making a garden.

In this bed, seeds can be planted in April which later will send up more plants, perhaps, than we shall need in the garden. Half the number would have cost considerable if we had had to buy them from the nurserymen.

Joseph has chosen for his seed-bed the place 48 
where Aunt Amanda used to keep her chickens. The soil there is very rich, and Timothy, who has turned it over to about the depth of a foot, has found it fine and free from stones. In the morning there is usually sun over this place, while later in the day the shade covers it completely. For these reasons it ought to suit flowers of different kinds. If Joseph had not been so lucky as to have this strip of rich earth at the Six Spruces, he would have been obliged to make it rich through artificial means.

Before Joseph and I came to live here and have a garden of our own, we never used the word manure. We did not regard it as a polite word. But we find that all gardeners talk about manure and the wonderful effect it has in making flowers grow, quite as freely as they speak of the flowers themselves. Arrangements have to be made for securing manure before flower-beds can be properly made. This year Miss Wiseman has sent us several wheelbarrows full from her pile back of the stable. Mr. Hayden also said to Joseph: "You just carry away from my place anything you wish, from the manure pile to the peaches growing under glass, only do it, my boy, when those gardeners of mine are asleep."

Now it would be very difficult for Joseph to catch Mr. Hayden's gardeners asleep. Their eyes are too sharp, too accustomed to spying out the pranks of Ben and Harry. For that reason, he 


\section{MAKING SEED AND FLOWER BEDS}

has not ventured to go over there for manure. Miss Wiseman, however, thinks of everything long in advance, and often sends things she knows it would be difficult for us to get this first year.

Not very much manure was needed to prepare the soil of the seed-bed, the earth there being so rich; but it is astonishing to see the quantity that Timothy is now using since he has begun making the flower-beds.

As I have said before, the triangle was our greataunt's favourite bit of lawn, also that this year it has been rolled and reseeded by Timothy. Even now, it has begun to look like a large, green carpet. We have decided to have no paths through it, but to make the flower-beds just where we wish and later walk to them over the grass. We both think it will look prettier if it has no gravel walks. Joseph expects to sow his seeds and set his plants so thickly that very little of the brown earth of the beds will be seen, and we hope to make the flowers look as if they grew right up in the grass.

I wish I could describe exactly the places where the beds are being made. As the flowers come up and show their colours, I shall know more about them. There is one bed in which I am especially interested. It is near the point of the triangle, just above where the soil is moist, and, although it partly follows the outline of the point, it is more curved. It is almost the shape of the moon in its first quarter. This bed, the outline of which was 
designed by Miss Wiseman, makes one forget the sharpness of the point and appears to give the whole triangle a better shape for a garden.

She first drove pointed stakes in the ground in the exact shape she wished the bed to be, and then she and Timothy, with Joseph's help, passed a line around the stakes, so that when Timothy began to take out the sods there would be no mistake about where he should put his spade. Miss Wiseman said it made her feel young again to drive stakes in the ground and to pass the line around them. When I tried it, it gave me such a pain in my back that I felt very old.

After Miss Wiseman had finished her work, she said that, as far as the eye was concerned, we had changed the shape of the triangle as satisfactorily as that of the Piazza of Venice had been changed by the Campanile. Neither Joseph nor I knew what she was talking about, so she explained that, before the old bell tower of Venice fell, very few people had noticed that the wonderful cathedral of St. Mark's stood on the bias, since the position of the tower had been such as to make the piazza appear a perfect rectangle. When the tower fell, alas, no one could help seeing that the piazza was not a perfect rectangle, and that the beautiful cathedral stood painfully out of line. Miss Wiseman loves Venice. If it were not an impossible place for a large garden, she would live there.

From her telling us this story about the bell 


\section{MAKING SEED AND FLOWER BEDS}

tower, and from the way the triangle appears to have lost its point by means of the new flower-bed, Little Joseph and I have learned that another important matter in gardening is the outline of things.

After Timothy had lifted out the sods of the curved bed, he dug down and threw out the earth to the depth of two feet. He then filled the whole bed half way up with manure, after which he alternated a layer of earth with one of manure, until it was filled level with the ground. Even after all this was done, he went to the woods and brought back a quantity of rich, black earth to put on as a top-dressing. This made the bed higher than the grass of the triangle, which, however, did not matter, since it would sink as the manure packed down.

I suppose all our other flower-beds will be made in this same way. Miss Wiseman has told Joseph over and over again that it is useless to try and grow fine flowers unless the soil is properly prepared. Perhaps some of his seeds would come up if he had just planted them in the unenriched soil, and perhaps they would also bear flowers; but it is not likely that these flowers would be large and strong and do themselves justice. Miss Wiseman says that no boy or girl would try to raise a kitten or a puppy without giving it proper care and food. Flowers, too, must be cared for and fed. Their diet, we have now found, is rich soil, 'water and sunshine, and it is the duty of gardeners to provide the first two of these. The good sunshine visits 


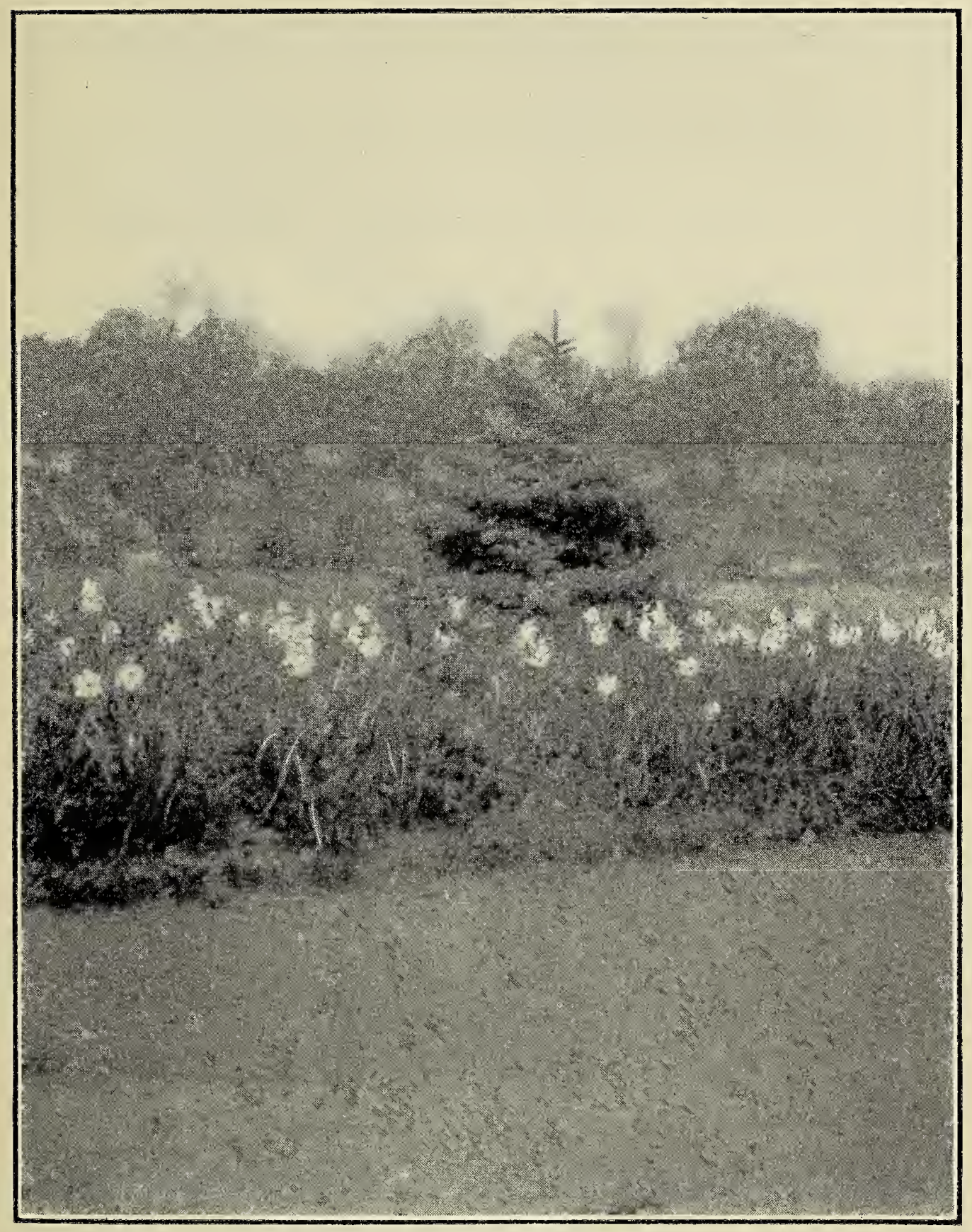

PLATE VI.-A BORDER OF NARCISSUS POETICUS 

them without coaxing. Since I have heard Miss Wiseman talk so much about feeding plants, it would make me sad to feel I had sown seeds in poor soil. I should think I was starving the flowers.

A little way in front of the wall where the vines are to be planted, we are to have a long, narrow bed for tall flowers; and a number of smaller beds are to be made on the side of the triangle near the south veranda. Already, Joseph and Timothy have spent two days talking about and making these beds, and so I have not yet staked out the place for my roses. Joseph is to have nothing to do with the roses. They are to be under my care alone.

Just as soon as this work of making the seed-bed. and those of the triangle is finished, Joseph will sow his seeds, for at last the spring really seems to be here.

At our neighbours' places beautiful tulips, daffodils and narcissi are now in bloom instead of the snowdrops, the Siberian squills and the crocuses that came in March. Miss Wiseman has a border of narcissus poeticus which appears to me most lovely. Whenever Joseph sees them, his sorrow is renewed that we have no spring flowers from bulbs at the Six Spruces. He does not intend to be without them another spring, and therefore is now saving some of his garden money to buy bulbs this coming autumn.

He has found out that gardeners must know how to take time by the forelock. Following their 


\section{MAKING SEED AND FLOWER BEDS}

methods, he has bought and planted many bulbs of Japanese anemones. These bulbs are often set out in the spring, and by the time September is here they come into bloom, lasting until frost. No doubt we shall then find them very lovely, since by that time flowers will be growing scarce in all gardens. Joseph has planted these bulbs somewhat at random about the triangle. The greater number, however, follow in groups the irregular line of the woodborder. Indeed, we are told that these Japanese anemones have a look not unlike some wild flowers. They were not difficult to plant in the soft loam of the wood-border. With a stick Joseph made a hole about six inches deep, dropped in and covered each one over with earth. $\mathrm{He}$ did this shortly after a rain.

We are much pleased at seeing our yellow bells so generously in bloom. They are something of a solace to Joseph's disappointment at having no spring flowers. In the woods also, just back of the fifteen hepaticas, windflowers, bloodroots and Dutchman's-breeches are in bloom. These latter are high up in the woods among rocks.

Nothing seems to disturb these little wild flowers. They live quite by themselves in the woods and manage things in their own way. No gardener makes their beds; no one feeds them with manure and fertilising powders. From year to year they come up in the same places, wearing the same delicate and timid look of spring. Sometimes I have 
MAKING SEED AND FLOWER BEDS 55

wondered if in the woods there was not a sprite who listened for the footsteps of spring and who slipped about and whispered to the buds to hasten and open their petals. 


\section{CHAPTER VIII}

PLANTING IN THE SEED-BED

LL Joseph's work at gardening is not out-of-
doors. He has to do a great deal of studying in "An Ambitious Boy's Garden," read many catalogues and talk with our neighbours and Timothy before starting actual labour in the open. Then there is Mrs. Keith, who likes to know just what Joseph is about. Not that she ever wishes to hinder him; sometimes she gives him ideas that are important; but usually she tells him whether our great-aunt would have approved of his plans. Little Queenie Perth laughs at Joseph when he talks about his flowers. She says the butterflies in her garden look prettier than his seed packages. $\mathrm{He}$ is delighted to hear and learn whatever experienced gardeners will tell him; for Joseph is not likely to be over-wise this first year of garden-building.

This week Joseph has learned to divide flowers into three classes: annuals, perennials, and biennials. He tells me that now he understands their 
differences perfectly, although formerly he thought that in their way of growth they were all alike.

Annual flowers are those that come up from the seed and bloom the first year; they last for that year only. Their seeds, in fact, have to be sown every season so long as they are desired. Sweet alyssum, mignonette and nasturtiums are among the annuals. Perennial plants are those that, once having had their seeds sown, last from year to year. Usually they begin to bloom in their second season, after which, when they have ripened their seeds, they die down to the ground. Their roots, however, still live in the earth and are ready the next spring to send up new plants. Often they reseed themselves, so that groups of such plants gradually increase in size. Perennials are hardy individuals, and for this reason Joseph thinks he will have many of them in his garden, as he likes to see the same flowers year after year in the same place. He would soon grow to expect them, and, if they did not disappoint him after the long winter, he would have the same pleasure in seeing them that he would if a friend had returned from a long journey. They would, he thinks, be more like the wild flowers in the woods, keeping to their own places and blooming at the same time each year. When once they have become established, it is not necessary to keep sowing them over and over again. On the whole, I can see that Joseph has already a strong partiality for perennials. 
The biennial plants have ways of growing different from either the annuals or the perennials. Like the perennials, they do not bloom until the second year, but, having once formed and ripened their seeds, they die completely. Although they must be watered and cared for during two seasons, they bloom but once, after which it is as if they had never been.

Joseph thinks that since we have no gardener but Timothy, the biennials would be a great deal of trouble for him to look after, with the reward of their blooming but once in two years, and so it is not likely that he will plant many of them.

Happily, it is now time to sow seeds. Joseph is busy putting perennials and some annuals in the seed-bed. There they will start and grow into little plants, which later he can set in their permanent places in the garden. This morning is warm, and the rain which lasted until breakfast-time has put the soil in good condition for planting, so he has taken out of the closet some of his precious seed packages. The perennials that he is sowing to-day are hollyhocks, columbines and oriental poppies. He wishes to have these in abundance and knows definitely where to place them. Of course he will have other perennials, and some perhaps that will bloom this year. In fact, it was Miss Wiseman who advised him to sow only these three.

A great many young plants are growing at her place that she cannot use, so later she will give a 
number of them to Little Joseph. She says that it is sometimes wiser for beginners in gardening to buy a few plants from nurserymen rather than to raise all they require from seeds.

Among the annuals in his basket of seed packages, Joseph has to-day mignonette, sweet alyssum, nasturtiums, candytuft, Shirley poppies and phlox Drummondi. The phlox, however, is the only one that he will put in the seed-bed. The others will all be sown at once on the triangle, since they like to stay where they are first planted.

Joseph had hardly started towards the seed-bed before Queenie.Perth came flitting across the front lawn, asking very loudly for Master Joseph.

"I want Master Joseph this minute," she said.

I told her that he had gone to the seed-bed, where he was probably very busy.

"Then I will go there, too," she replied.

Queenie appeared to have something in one of her hands which she kept closed tightly. I went out with her to the seed-bed, since she did not know the way, and there was Little Joseph making furrows in the earth with a pointed stick.

"I have something," Queenie said. "Guess!"

Joseph went right on making the furrows. "A doll," he answered after a while.

"Something harder to get than a doll," Queenie told him.

Joseph still went on making the furrows. 
"Stop that and guess," Queenie exclaimed, stamping her tiny foot.

"You have caught a butterfly," Joseph said, noticing her closed hand.

"I have a bird's egg," she told him in great triumph, showing it to us in the palm of her hand.

Joseph then stopped making the furrows and looked at the egg. It was small and of delicate cream colour, flecked all over with brown.

"Where did you get it?" Joseph asked.

"I took it," she answered, "from a little house by Auntie's barn. It was full of sticks, but I pulled them all out, and then I put my hand in and got the egg."

"I believe it is a wren's egg," Joseph said solemnly, remembering how these birds in our own house had barricaded the door with sticks. "You should not have taken it."

"Oh, birds are everywhere," Queenie replied. "They are in the air and in the trees, and some are in the shutters of my window. They wake me up every morning chirping so loudly. I never took a butterfly's egg," she said further.

"Butterflies come out from a chrysalis," Joseph said reprovingly, and then he went on making furrows for the columbine seeds.

Just as soon as he tore open the packages of seeds, Queenie wished to help him drop them in the earth, and, after some coaxing, Joseph gave her a few, showing her how to hold them. He went 


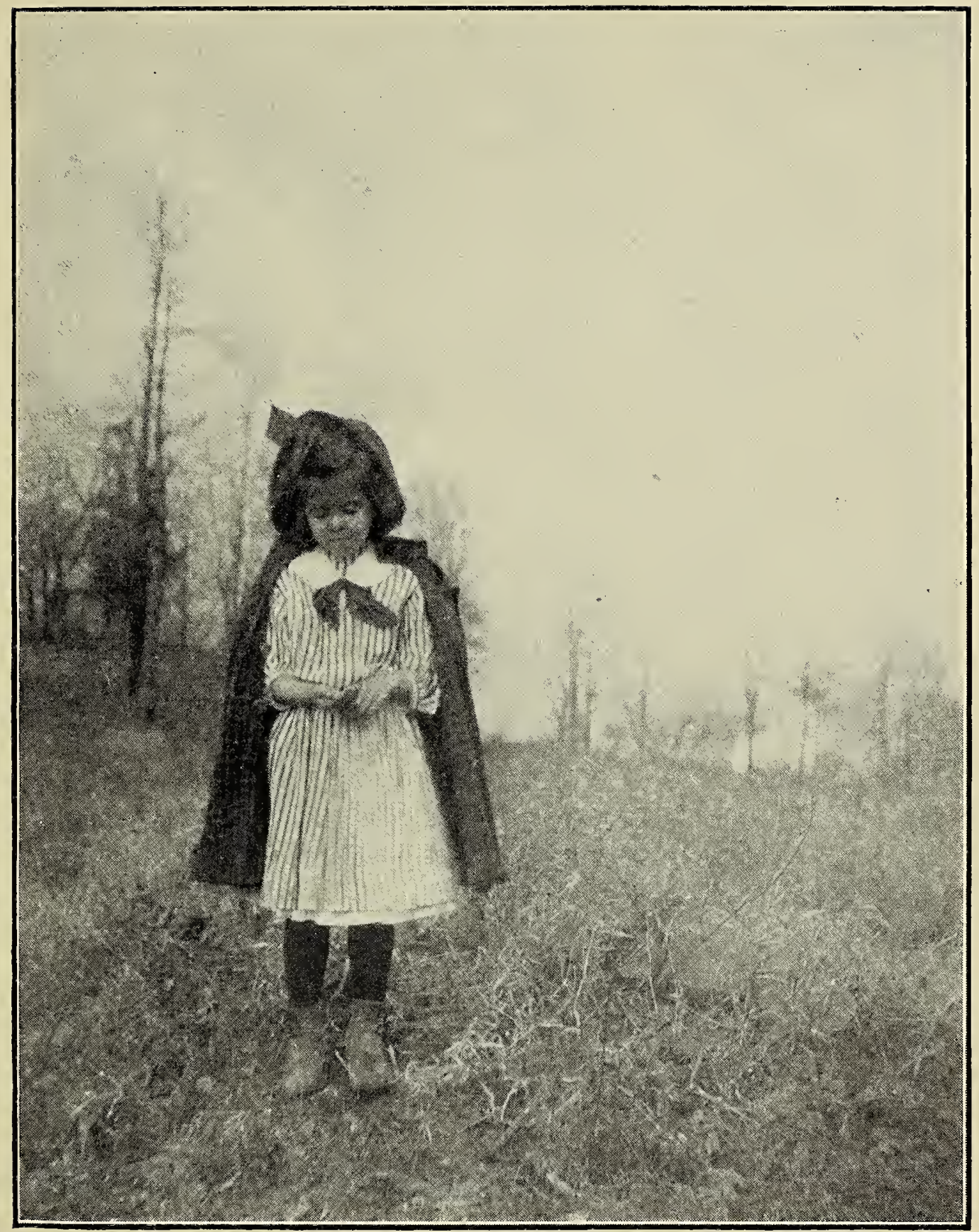

PLATE VII.- “I H HAVE A BIRD'S EGG" 

along just behind her, drawing the earth over those she had planted. Queenie's fingers are so slight and delicate that she handled the seeds even better than Joseph. She was careful, besides, not to waste them as she took them from the package, and not to drop them in the wrong places. Joseph had several colours of columbines and planted each in a furrow by itself. When this was done he placed labels at the ends of the furrows telling all about the seeds. When transplanting time came they would be of great help to him.

The seeds of the hollyhocks were larger than those of the columbines, but even these Queenie handled with the utmost care. She helped Joseph so skilfully that he had almost forgiven her for taking the wren's egg, when he suddenly remembered to ask her what she was going to do with it.

"Nothing," she said, and threw it on the ground.

It broke, of course, and inside there was a tiny bird, an ugly-looking object.

"You ought to be ashamed," exclaimed Joseph. But Queenie did not mind at all, as long as he let her help him with the seeds.

Just then Mrs. Keith came to the seed-bed, and, when we told her that Queenie had taken the egg and then broken it for fun, she was shocked.

"It is a wren's egg," she said. "I have seen them many times."

"How could you if you did not steal them?" Queenie asked. 
"I have seen wren's eggs that were stolen by bad boys," Mrs. Keith answered, "but this is the first one I ever saw taken by a little girl."

Then she took Queenie away with her to the house to tell her how very wrong it was to steal birds' eggs and to beg her never to do it again as long as she lived. Mrs. Keith always keeps a jar full of cookies in the pantry. Queenie is very fond of her.

Joseph went on sowing. He next put in the oriental poppies and then the phloxes. These phlox Drummondi are annuals. I watched Joseph plant them, and saw that the furrow he had made was not more than an eighth of an inch deep.

After planting these seeds, Joseph concluded he would do no more until the morrow. He had still to water them thoroughly with the rose-sprayer. Water falling on them heavily as from a hose would have greatly disturbed their position in the earth. It was growing late in the afternoon, and we were both eager to know what Queenie and Mrs. Keith were doing; so, after the watering was attended to, we went back to the house.

We found Queenie sitting on the back veranda between Timothy and Mrs. Keith. She was listening to a story that they were together telling her, and of which she said she did not believe a word. But Joseph knew it was a true story and very beautiful.

It was of a caterpillar that spun about itself a 
little house, or silken chrysalis, and lay coiled inside, resting during the whole winter. It neither saw its friends nor ate nor drank such food as Queenie knew about. Many people might have believed this crawler of the earth was quite dead. After a while the door of the chrysalis opened, and out of it appeared not the caterpillar, but a beautiful butterfly whose name was painted beauty. Perhaps the butterfly had been given this name on account of the exquisite rose colour on the hind part of its fore wings and the dark, eye-like spots on its posterior wings. The upper surface of the butterfly's wings is nearly black, with marks of orange and white, and it has long feelers which appear to point the direction in which it shall fly. It is a butterfly that does no harm in the world, but just flitters around, loving and caressing the flowers. In the autumn, it seems to like the purple asters very much and sometimes carries the golden dust from one flower to another. The painted beauty, Mrs. Keith said, was always beautiful and good.

"Perhaps it will come to our garden this summer," Joseph said.

"I will catch it, then," Queenie told him, and indeed we both knew that at home she had a butterflynet. 


\section{CHAPTER IX}

\section{JOSEPH CONTINUES SOWING SEEDS}

$\mathrm{HE}$ weather has lately favoured Joseph's gar-
den greatly. Although he was disappointed that he could not sow more seeds the day Queenie Perth came with the wren's egg, the morrow proved equally fine for such work. There was a mist in the air, which kept the soil moist; yet rain, which might have washed the seeds from the ground, held steadily off. Again Joseph started from the house with his basket of seed packages, this time in the direction of the triangle.

$\mathrm{He}$ took out first his packages of nasturtium seeds. These were annuals, and he had two kinds of them, climbing and dwarf nasturtiums. He soon decided to sow the first kind in the very narrow bed by the wall, where the vines were to be planted. Here these seeds took up but little room. Joseph put them about an inch deep in the ground. In this spot the sun could find them easily, and the sun and nasturtiums are very fond of each other.

It was with more difficulty that he made up his mind where to sow the dwarf nasturtiums; but, 
after a while, he had a happy thought about them. They like sun as well as the climbing ones, and they also like rocks. So he brought several stones from the woods and placed them on the ground in front of the wall, very near where he had planted the other nasturtiums.

"They can grow here," he said to me, "and it will look better to have the two kinds together than to have them in different places about the triangle." The dwarf ones, he had learned, would begin to bloom earlier than the others; but, as they grew at the base of the climbing ones, it would appear as if all had begun to flower at once. Gardeners, Joseph had read in "An Ambitious Boy's Garden," have often to play little games of deception with their plants.

Since the nasturtiums were planted at the end of the wall that comes up near the house, it will be easy for me to step out and gather their flowers whenever I choose. I like to see these bright flowers arranged in green glass dishes for the dining-room. There is something very clean and cheery about their look. They are among the flowers that appear as if they were always smiling. Besides, Mrs. Keith says that the leaves of the dwarf nasturtiums make a spicy salad.

In our mind's eye, we could both see just how these plants would look when they were in full bloom, yet on this April day the wall, the ground and the stones appeared scarcely different after the 
seeds were planted. There were only the small label-sticks in the ground to let a stranger know about the gay beauties we were expecting later.

The sweet alyssum and the mignonette Joseph sowed in several places. He used them wherever he wished flowers to form borders for beds. The alyssum seeds he put in furrows about half an inch deep, while the mignonette was not planted as far down.

I felt pleased that we were to have these two flowers in plenty in our garden. They are both fragrant, and I think that a sweet-smelling flower is better than one with no scent. They are also both attractive in bouquets. Often I tell Joseph that I shall work hardest in the garden when picking time comes.

Next Joseph sowed the candytuft, putting it in the ground to about the same depth that he did the mignonette. He had only white candytuft, and, while in several places he planted it for edgings to the borders of beds, in another spot he sowed so much that it will form a fine mass by itself. Nevertheless, he did not use all of the seed that he had, for, in order to have it stay with us until frost, he would have to keep on sowing it about every two weeks.

"Dear me," I said, "will you have to do that with all the seed that you have planted?"

"Oh, no," he answered, "the mignonette and 
candytuft are the only ones so far that will have to be sown in succession."

Joseph's knowledge about seeds shows how often he has read "An Ambitious Boy's Garden."

Finally Joseph planted the Shirley poppies. It seemed to me that he had more of their seeds than of all the others put together. He sowed them rather thinly and only sprinkled the earth over them. He has learned that they would not wish to push themselves up from the bottom of a furrow, no matter how shallow. He planted them in many places, but especially in the circular bed that cuts off the point of the triangle. The soil in this bed is not at all boggy, as one might suppose from being so near the moist corner. As I have already said, it was prepared in the regular way by Timothy, and its soil is fine and light.

I shall love these poppies when they bloom. Once I saw them last year, and they seemed to me like cups made by fairies out of tissue paper. But truly we shall have to wait a long time for them to bloom.

The mist that has hung over the garden has gradually cleared and the day has suddenly turned as chilly as if it were early October instead of April. I hardly like to mention such a disagreeable word as frost to Little Joseph. He perhaps has thought about it himself, for he told Mrs. Keith that, when he had time, he would make a cheese-cloth cover for his seed-bed; but that to-night he intended to 
spread newspapers over it if Mrs. Keith thought there was danger of frost. Mrs. Keith is more weather-wise than any one else at Nestly.

Poor Joseph, I hardly see when he is to find time to make a cheese-cloth cover for his seed-bed, let alone covering the many seeds he has planted in the triangle. At this season of the year there is something to do every day in the garden, and, if he works all the time, I am afraid he will grow dull, like Jack who had no play. But Joseph could never be really dull. $\mathrm{He}$ is the kind of boy that likes to be busy every minute. It is only the "sandman" who makes him forget there are things to be done.

After seed-planting, all gardeners must be on the watch against burning sun, heavy rains and high winds which are likely to harm the tender sprouting plants. Even if Joseph cannot find time this year to make the cheese-cloth cover, it is something that can be done in the house next winter. With its aid, he would have a better chance of success and might even start his seeds earlier out-of-doors.

At Nestly Heights and at Miss Wiseman's, many seeds are started each season under glass, and not until all danger of frost is past are the young, well-grown plants set out-of-doors. Since Joseph never expects to have glass houses at the Six Spruces, he must contrive in other ways to give his seeds an early start. But then he is more ambitious even than the boy of his book. He hears of few 
things that he thinks will not be possible for him to do after a while. In gardening, there is a great deal of "after a while," especially during the first season.

Mr. Hayden likes to come and walk about the Six Spruces with us, and we have both become so keen in observing his ways that we can tell whether it is the northeast wind or the west wind that is blowing about him. Naturally we care for him most when he is like the west wind. When he is in one of his northeasters, as Joseph says, he finds fault with everything that we have done and talks a great deal about Aunt Amanda, and how she would have disliked seeing the triangle cut up with flower-beds.

Little Joseph had sown the last of the poppy seeds when Mr. Hayden came to-day. I was then urging him to come into the house and rest, for he really looked tired, although that is something, he says, which boys do not talk about as much as girls. We noticed at once that the west wind was blowing about $\mathrm{Mr}$. Hayden even if in the garden it was northeast.

"Planting seeds?" he asked, "or blue roses? Well, you beat my man at the flower show this year and I will give you a hundred-dollar bill."

Then he slapped Joseph on the back so hard that he felt as if the wind had turned to a hurricane. Mr. Hayden came to tell us that he had punished both Ben and Harry for the sake of discipline; and 
to remind us that he had another son away at college who was a remarkably fine lad.

"He is a blue rose," said Mr. Hayden, "and no mistake. How about pansies?" he next asked. "Have you any about the Spruces?"

We told him that we had never thought of pansies.

"Well, they are my favourite flowers," he said; "you had better get some plants from my gardeners. I never feel comfortable in a garden without pansies. They make me understand the nature of all the other plants. They not only have petals, you know," he went on, "they have faces. I have seen ever so many pansies that looked like old ladies, and old men, too, for that matter, although usually they look more like hickory nuts. Once I saw a white pansy with pink tips that looked like a young girl. Not your sister," he said to Joseph with another hurricane slap, "she is like a rose."

I saw Joseph look at me very critically; but I hardly think brothers ever notice that their sisters look like roses.

Lately I had read about carpeting rose-beds with pansies, and I had seen them so planted at a beautiful place where we had visited. But I did not like the idea. Pansies have such a different look and character from roses that the two seem to me out of harmony. I should never choose them as a 
carpet for my rose-bed, I would rather see the bare earth.

Mr. Hayden was as merry as a little wind that makes the leaves dance, and often called me White Rose. He said that he had a great secret up his sleeve which, however, he had no intention of telling. Joseph, of course, thought that he was going to send us a number of pansy plants, while I thought it more likely he would send a white rose, one of the kind that would climb over the wall. But neither of us ventured to ask him to change his mind and to tell us what the secret might be.

Before he went home, he said that one of the sorrows of his life was that he could not have a talk with Aunt Amanda. This made Joseph and me wonder if the wind had changed. 


\section{CHAPTER X}

FINDING FERNS TO TRANSPLANT OR three days in succession now, we have been
on long tramps in the woods. This is because Mr.Hayden's son Percy is home for the Easter holidays and seems to find more pleasure walking about the woods than he does in his father's gardens. The fact that he was coming shortly is the great secret Mr. Hayden had up his sleeve. Joseph and I call this son "Mr. Percy," for when we say "Mr. Hayden" we mean the father. He has taken a great fancy to Little Joseph, but insists that I go with them on their tramps. He knows a great deal about ferns and flowers, but not in an important, book-like way. Some people always speak about flowers as if they were reading in a catalogue.

"Why, here are fiddleheads," he said the first day we went into the woods together.

We looked, and saw a number of green, sticklike things with curled-over ends standing up in a clump together. They were covered with a thick white wool that probably kept them warm in these 


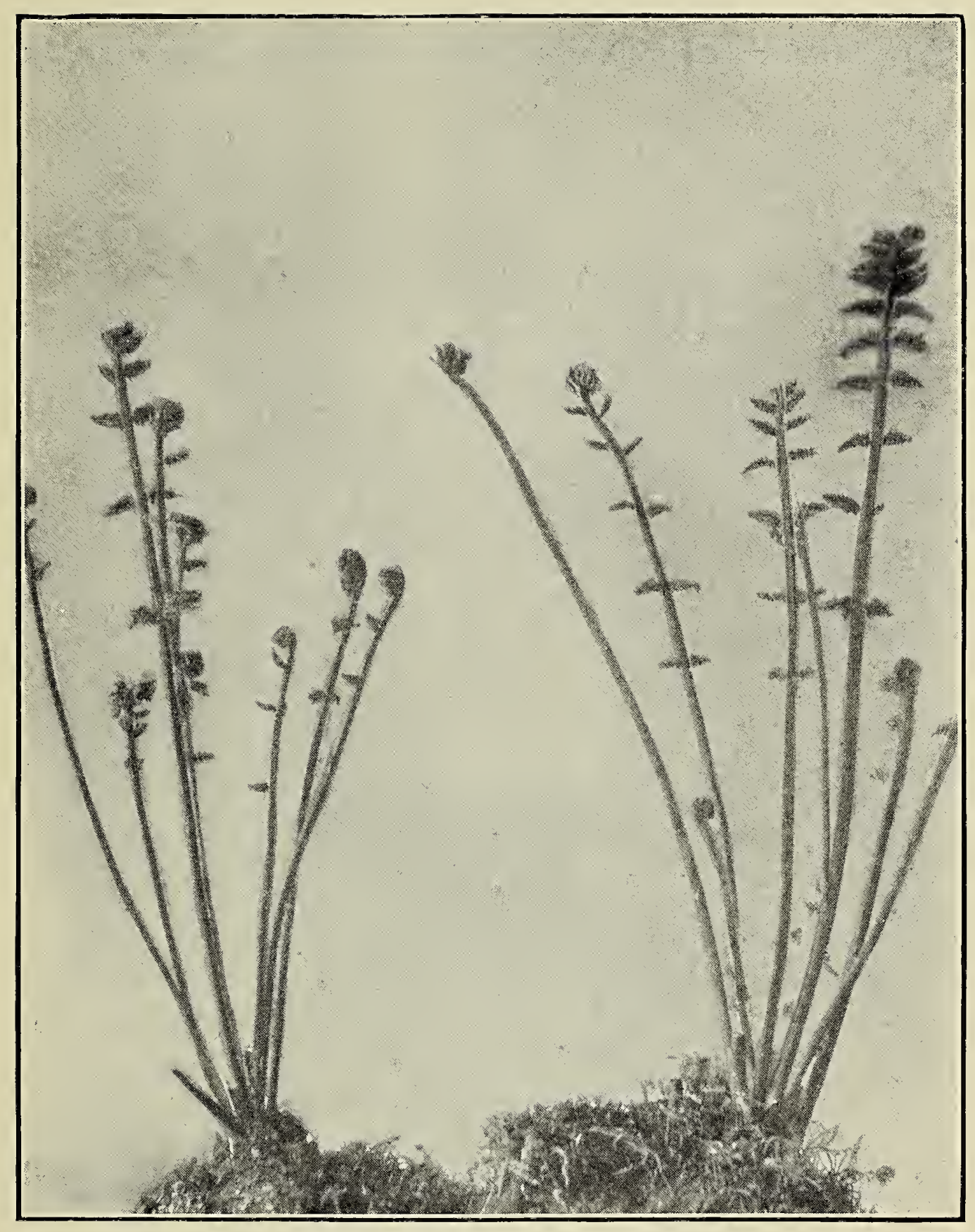

PLATE VIII-WIDDLEHEADS 

uncertain spring days. Hepaticas were close by and bloodroots and dog's-tooth violets were not far away.

"Why not transplant a few of them in the moist point of your triangle?" Mr. Percy asked. "They will unfold into tall, strong ferns, and if we take them now they are almost sure to live. I have found the early spring a better time for transplanting ferns than the autumn. Their fronds are not unfolded now, so there is no danger of their breaking."

This seemed a splendid idea, as we were much in need of tall, green plants at the moist corner. Mr. Percy and Joseph then set to work to take up the fiddleheads. I had a basket with me, a trowel and a newspaper, as I thought I might find some wild flowers for transplanting. The trowel proved very light for taking up the firm, interwoven roots of the fiddleheads, which I thought must have been making roots in this spot for a great many years.

Mr. Percy told us that, as the days grew warm, the woolly covering of the fiddleheads would turn a brownish yellow and gradually fall away. He showed us also its "heart of Osmond," which is really the buds for years to come, and lies at the crown of the brush-like root-stock. This part of the fern, he said, tasted very much like raw cabbage. But to gather it, the plant itself would have to be destroyed, and neither Joseph nor I care enough about eating raw çabbage to make us do 


\section{FINDING FERNS TO TRANSPLANT}

such a thing. It is only the young crosiers, or unfolding fronds, that Mr. Percy called fiddleheads. He said the plant itself was a brake-the cinnamonfern. In talking to himself, however, he called it Osmunda cinnamomea.

I do not remember all that Mr. Percy said, because I was so eager to see if he and Joseph would succeed in getting its large root-stock up from the ground without hurting the fiddleheads. The curious look that these latter have in the woods I shall never forget, and, now that we are to plant them in the garden, I shall be able to watch them unfold and to learn for myself about their fronds. In speaking of ferns, Mr. Percy said, we must say fronds instead of leaves.

He and Joseph had a hard time getting the two ferns they chose to transplant loosened from the earth. They dug around them in square blocks with the trowel, and then gradually worked them free from the rest of the root-stock, which was altogether too large to carry away. Their work would have been easier if they had had a spade. When at length they were in my basket, Mr. Percy carried it. It was indeed quite heavy.

Before we had gone much farther, we found the maidenhair fern. This fern was well known to both Joseph and me, but neither of us would have recognised it as we saw it then, had it not been for Mr. Percy. Its crosiers were beginning to uncoil in their curious way, and parts of them were cov- 


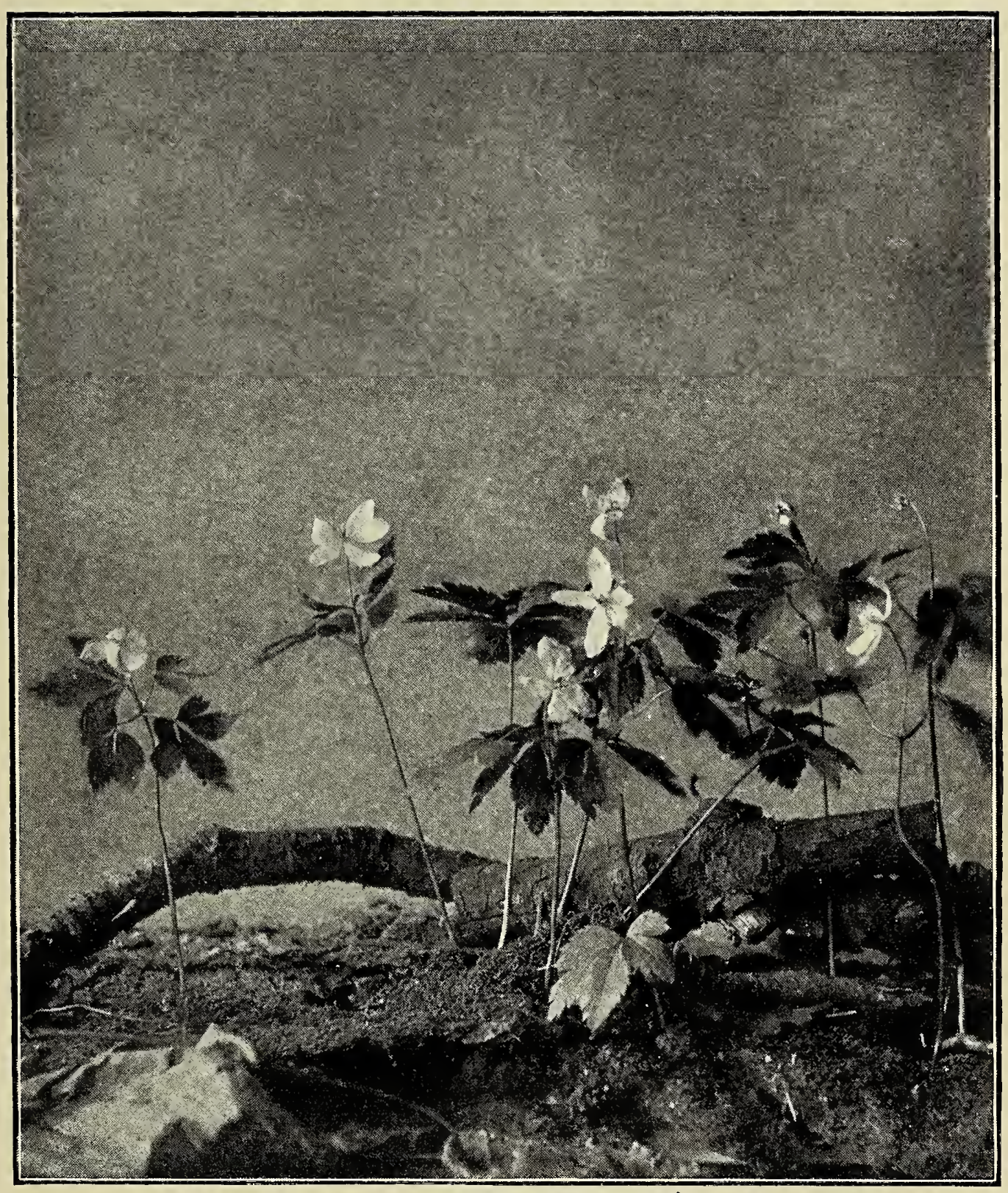

PLATE IX.-WINDFLOWERS 

ered with a bluish bloom, such as we see on grapes. The little parts that would later open out and be green were then dull red. Neither of us doubted that Mr. Percy was right, and that some day this strange little bunch of sprigs would turn. into our own beautiful maidenhair fern. It then looked much less like it than a baby looks like a man.

Joseph thought it very wonderful that Mr. Percy should be able to tell what all the little sprigs and tiny green things were going to be when once they were full grown. We thought he must have wandered many times in the woods and observed sharply the things he saw. He quickly set himself about taking up the maidenhairs, since he said they also would thrive in our home garden. Their rootstocks were not as hard to handle as those of the fiddleheads. They were more slender and wiry, and stayed nearer the surface of the earth. Soon we had five of them in the basket.

"They will make a showing this year," Mr. Percy said, "and, every year after, the clumps will grow larger and more beautiful."

There were hepaticas and windflowers where these maidenhair ferns were uncoiling. The windflowers were now in full bloom in our own woodborder, not far from the place where Joseph had planted the hepaticas. They looked so frail and delicate that I felt quite afraid to walk among them.

"This year," Mr. Percy said, "the season is backward. It is now the twenty-fourth of April, and I 


\section{FINDING FERNS TO TRANSPLANT}

have often found these ferns as well grown ten or twelve days earlier."

I was thinking it time to go home, when $\mathrm{Mr}$. Percy said that, as long as we were out for ferns to-day, we might try to find the lady-fern and take it along with us. There was still room in the basket, although its heaviness had increased.

"The lady-fern.!" I exclaimed. "Is it one that ladies like especially?"

"Well, perhaps not the ladies of to-day," Mr. Percy answered, "because they have learned to like so many kinds of ferns. The truth is that the fern itself is a lady. In ancient times, it was called female fern, which has not so poetic a sound. The folk of long ago believed that the seeds it bore could make people invisible. Imagine," Mr. Percy continued, "how amusing it would be if I should put some of this mystic seed in my shoes, or in my pockets. You would still hear me walking about and talking, but you would not be able to see me. I might drop in at the Six Spruces at any time of the day and find out all your secrets."

"That, of course, is a fairy tale," said Joseph, who is something of an authority about sprites and witches.

"It may be that now," Mr. Percy answered, "but truly, in the days when it was called female fern, it was believed to have this and many other curious powers."

"I hope we are going to find it," I said. 


\section{FINDING FERNS TO TRANSPLANT}

"Oh, we are sure to do that if we keep our eyes open," Mr. Percy replied. "It grows in most places about here that are moist and shady. Here it is now!"

I thought it less interesting than the fiddleheads -perhaps because it was not covered with a warm wool. Its stalks were deep wine colour, and the uncoiling fronds were light, yellowish green. They grew up from the root-stock in tufts that were large and circular. I could imagine better how they would look when unfolded than I could the fiddleheads.

"You will both think this is an old acquaintance when you see it uncoiled in your garden," Mr. Percy told us. "In fact, you must have seen the lady-fern again and again before now. Sometimes it wanders out from the woodlands or swamps to live along the roadways. I have even found it in our stony back-pasture. This year, however, you will really become its friend."

All the time that Mr. Percy was talking, he was working steadily to get its large root-stock up from the ground. I began to think that ferns had a much stronger way of fastening themselves in the earth than was known to either wild or cultivated flowers. When he had taken up several lady-ferns, we turned in the direction of home, Mr. Percy saying that later he would take us where fronds uncoiled beside some lovely wake-robins. Once only we stopped on the way to watch a red-headed wood- 


\section{FINDING FERNS TO TRANSPLANT}

pecker going up the side of a tree. Every second or two he stuck his long bill into its bark to get some insect; and he must have had a feast if, every time he pecked, he secured prey. He hopped along at a lively pace, appearing not to notice that we were watching him. What he did at other times I had no idea, but, unlike the wrens and the robins, he was not carrying his finds home to a little mate on the nest. Everything he found, he ate himself.

The spring air and the long walk had tired me by the time we reached the Six Spruces. This was not so, however, with Joseph, who was as enthusiastic as when we first started, and had now, he said, to plant the ferns. Mr. Percy advised him to put the maidenhairs on the slight slope of the coppice where it is shady, yet somewhat open, and where they might be seen from the triangle. The fiddleheads they planted near the point of the moist corner, and the lady-ferns they placed in a group at the side.

"All of these ferns do splendidly under cultivation," Mr. Percy said. "But they will now require a daily watering, especially if the earth should become dry."

We felt it very encouraging that something we had planted would now grow and unfold at the Six Spruces as soon as it would in the woods.

After Mr. Percy had gone back to Nestly Heights, Joseph and I wondered how it was that 


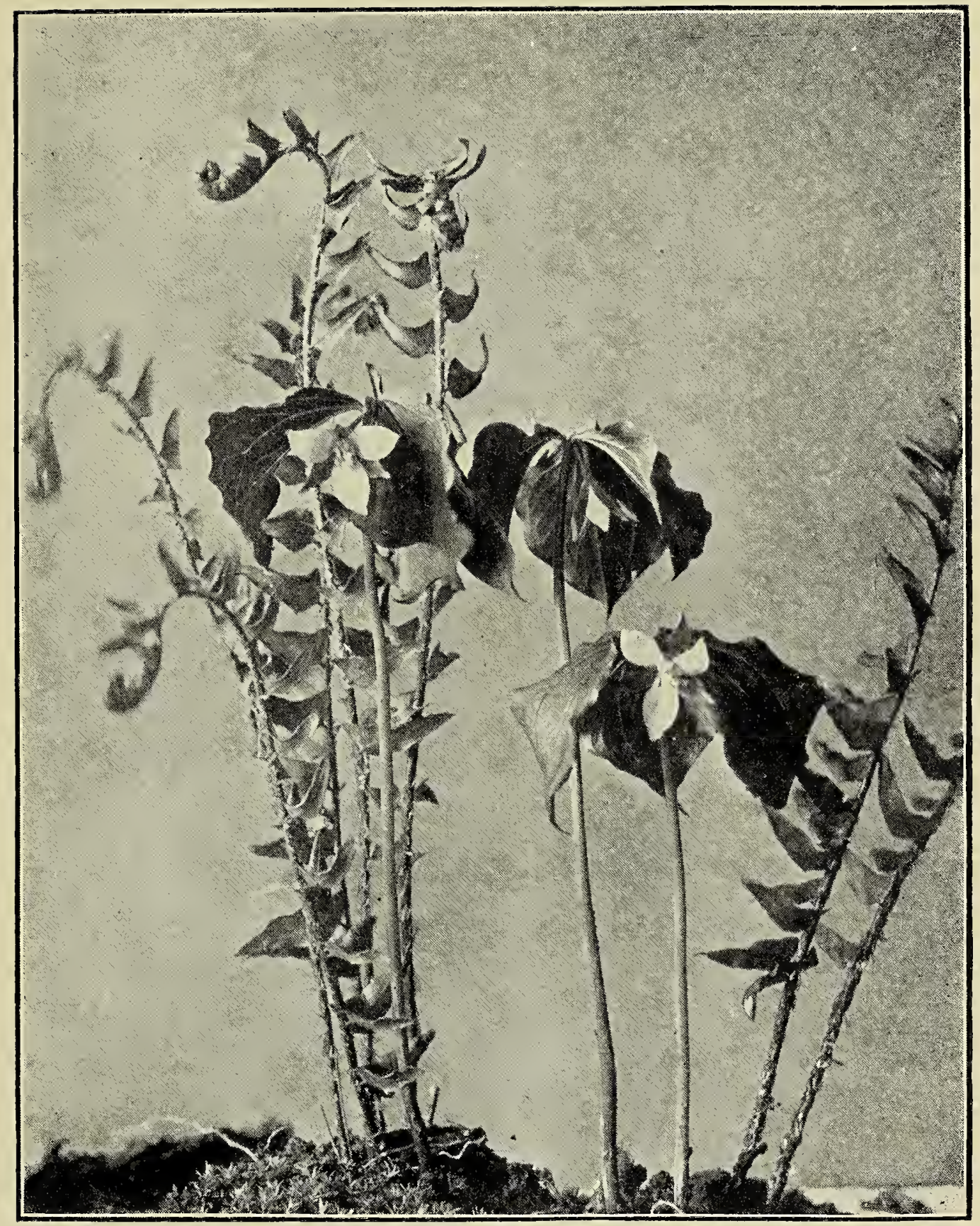

PLATE X.- "FRONDS UNCOILED BESIDE SOME LOVELY WAKE-ROBINS" 



\section{FINDING FERNS TO TRANSPLANT 79}

he cared so much to go out into the woods with us for fęrns and help transplant them, when at his place there were such beautiful and rare ferns in one of the glass houses. We thought it must be because he liked to tell us all the interesting things he knew about the wild plants of the woods.

"We should not have known the plants were ferns if it had not been for him," I said.

"Nor should we have seen that woodpecker," Joseph replied.

Then we both wondered why it was that he did not act a day older than ourselves, and if he would come again. 


\section{CHAPTER XI}

\section{MY ROSARIUM}

$A^{S}$ yet I have said nothing about my rose garof my energy, and, incidentally, my money. Of the former, I have as much as most girls, while of the latter my bank holds but twenty-five dollars. Yet, with the roses that have been given me by Mr. Hayden, and with all that I shall learn later about budding and striking cuttings, I may perhaps, in two or three seasons, have a beautiful rosarium. There are no flowers I love as much as roses. I love them enough to have always a thought for them, never tire of watching them, and even regard as nothing the trouble I shall probably have in keeping their insect pests away. It is because I love them so dearly that I feel I can make them grow.

For some time Joseph and I could not decide where the rosarium should be placed. Then suddenly a thought occurred to me. It should be near the middle of the triangle, over by the side that borders the wood; and the various beds for the roses should spread out from the rustic seat that 
is placed there, as if they were the sticks in a fan. Imagine how delightful it will be to rest on this seat, and to feast our eyes on the whole rose garden. Besides, if I have it in this place, it will not interfere with Joseph's hardy-flower beds. The roses will be quite by themselves, a condition they greatly desire. Over this spot the air circulates freely, another point about which roses are particular. An abundance of sunshine will there visit them, and yet they will be shut off from too much wind by the wood-border. A better spot for growing roses, Miss Wiseman says, could hardly be found ready made; for in this way she invariably speaks of the triangle and the bordering coppice. She had to plant many trees and flowering shrubs about her own rose garden, to act as wind-breaks, since roses do not like rough breezes.

The long and narrow beds, arranged like the sticks of a fan, have already been prepared by Timothy, in exactly the same way as the other beds were made. From time to time, however, the roses will need more fertilising than Joseph's hardy'flowers. Mr. Hayden says they are the most greedy feeders of all plants, which seems an ugly expression in connection with roses, although quite true. I have noticed that, whenever Miss Wiseman and her gardener, Mr. Bradley, talk about the roses they expect to send to the flower show this year, the conversation begins and ends with a criticism of various kinds of fertilisers. 
Joseph has started a manure heap, not far from the seed-bed behind Aunt Amanda's old chickenhouse. It cannot be seen from any part of the triangle, although we have become such garden enthusiasts that its ugliness would be condoned, in view of the beauty and strength our flowers are likely to receive.

The neighbours have said quite generally that it is too bad I could not have planted the hybrid perpetual and hardy roses that $\mathrm{Mr}$. Hayden has given me in the late autumn, instead of in the middle of April. Still they were moved and transplanted with so much care that I am hoping they will know nothing about it. It was surprising so many agreed that the season was excellent for planting monthly roses; for, when one starts a garden in spring, it seems as if the greater number of things should have been attended to in the autumn.

Those who have watched roses know that the so-called hybrid perpetual and hardy roses bloom with the great army of roses in June and July, sending out occasionally a few flowers in the autumn. The monthly or ever-blooming roses continue opening their flowers throughout the growing season, sometimes until overcome by frost. When planting, it is best to keep these two classes separate, as in the late autumn the monthlies require much heavier winter covering than those which are hardy.

Had I chosen roses exclusively from the catalogues and from what I remember about them, I 


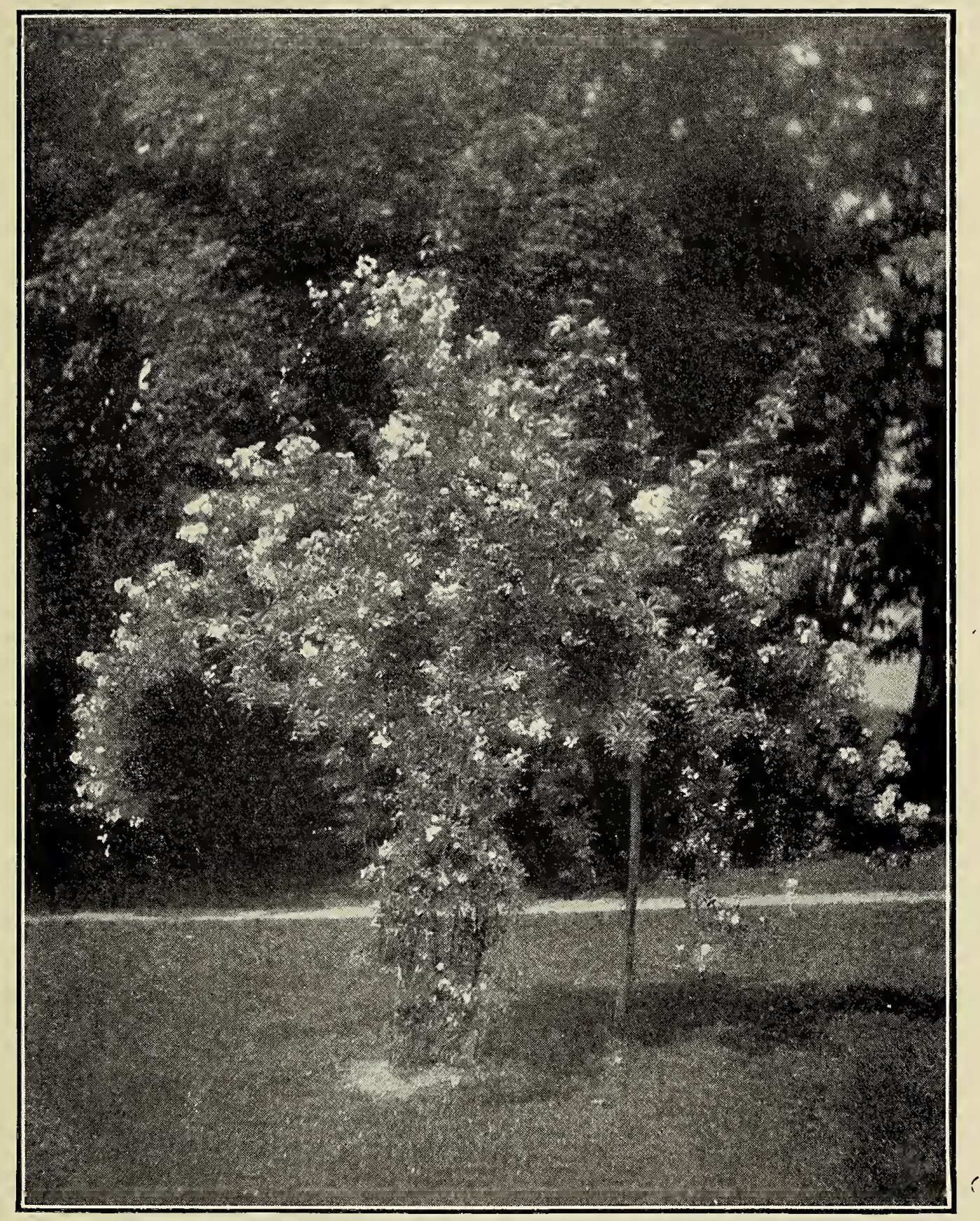

PLATE XI.-A ROSE FANTASY 

think I should have had in my rosarium only monthlies of either white or red. I can imagine that a rose fan made of these two colours might be very beautiful from June until October. But there might have been unexpected disappointments which I am spared by having had so many hardy roses given to me.

Those that Mr. Hayden contributed to the fan, all of which, he said, were roses of the highest character, were red, pink, and white, with one yellow rose called Soleil d'Or. This name was very appealing. Among the red roses were Ulrich Brunner, Marshall P. Wilder, Prince Camille de Rohan, and Victor Verdier. The pink ones were named Mrs. R. G. S. Crawford, Mrs. John Laing, Baroness Rothschild, Clio, Madame Gabriel Luiget, and Paul Neyron.

The one white rose was called Frau Karl Druschki, a name I thought given it by a very stupid gardener, although Joseph said it was more likely the flower received its name from a very clever individual, since it had become celebrated for its beauty. In "An Ambitious Boy's Garden," there is not a word about roses, so I suppose Joseph heard this either at Miss Wiseman's or at Nestly Heights.

I decided to plant the red roses in the middle beds of the fan, keeping each kind by itself. The white were in the beds on either side, then came 
single beds of yellow, while the end beds on each side of the fan were left for pink roses.

Near where they all taper down into a semicircle, another bed following this outline was made for the monthly roses on which I had spent my money. Among them I had but three kinds, the Killarney, the Kaiserin Augusta Victoria and the Perle des Jardins. Their colours were pink, white and light yellow.

This was the arrangement I had intended for my rosarium. But for this year, at least, it was beset by a difficulty. The labels marking the roses that Mr. Hayden gave me read merely red, pink, white, or yellow. Now there are ever so many shades of red, some of which look well with pink, while others do not. Perhaps if I had consulted one of Joseph's catalogues, or a book on roses, I might have found out more about their particular shades, and then have planted them accordingiy. But it happened that the roses came late in the afternoon, while Timothy was at the Six Spruces, and the best thing to do was to get them planted as soon as possible. They had not a very inspiring look. Evidently, they had been clipped back by the gardener at Nestly Heights, and, not having begun to send out their new leaves, were just sticks and thorns.

Still, it was a great thing to see so many little rose-bushes actually planted in a formal, pretty design, and to feel that it was indeed my own rosa- 
rium. As the roses begin opening, I can watch them carefully and learn all the particular little points which make each one different from another. Some of them also may die, and then I shall have to find out the cause; others may grow too high, over-reaching their neighbours, and I shall thus learn where best to transplant them in the autumn. After studying and caring many years for them, I may become a Rosarian, or an authority on roses. Once Joseph heard of a great lady in England whose chief pride was that of being a Rosarian.

Besides the monthly roses, I bought three crimson ramblers for Joseph, and two other climbers, which are called Wichuraianas. The ramblers he has planted by the wall dividing us from Nestly. Heights; the Wichuraianas, on the contrary, have been set out by the moist corner of the triangle, where the ground rises in a little bank. These latter bear small, sweetly-scented, white roses, and their foliage is vividly green and glossy. They will either climb over arches that Joseph may make some day, or run along on the ground. They begin to bloom after the crimson ramblers have faded.

In buying the monthly roses for the base of the fan garden and the climbers for Joseph, I have spent nearly all of my twenty-five dollars. But there are nearly forty roses in the bed, large, strong plants. Miss Wiseman says there is no economy in buying poor stock. I, at least, am content. As soon as the roses begin to bloom, they will give me 
more pleasure than the money could have done if otherwise expended. Even now, I like to watch the bushes, although they are only bare sticks standing above the bare earth.

If ever I write a story, it will be about a rose. The rose is so romantic. It has had its petals sprinkled over the dishes at feasts of Cæsars, and has been worn near the hearts of queens. Its fatherland is said to be in the northwestern part of Asia. At least the rose from which the first perfume was made grew there, and its sweet scent has held sway with kings. I can never quite like people who are indifferent to roses. There is such a grace about them, and yet a sprightly air, as if they wished to speak. Roses never nod their heads. They hold them high. They are themselves queens.

All this time that I have been telling about my rose garden, Joseph has been away playing with Queenie Perth. It sounds odd to speak of Joseph playing with a little girl, as usually he is so grave, and spends his time working in the garden. But he likes Queenie, although he knows she is spoiled and often naughty. She can make him quite forget his seriousness when she herself is in one of her funny moods.

I see Joseph now returning by the circle in front of the house. No doubt he has been reminded by the twilight that it is the poetical time of the day which we give to changing clothes. But no, he has 


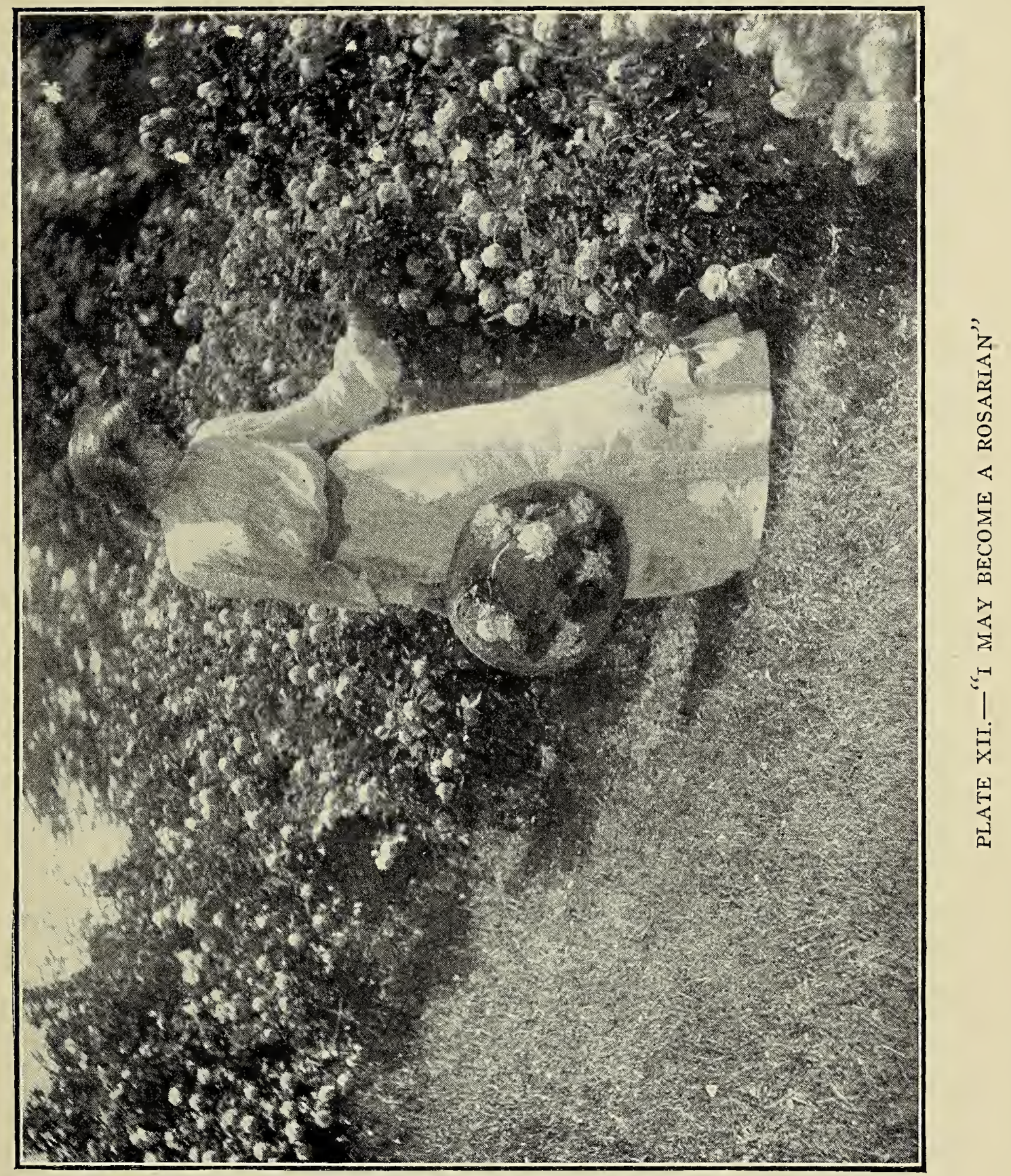



not come on by the circle. He has crossed over and gone in among the six spruces. I will join him there before Mrs. Keith catches sight of either of us. I must tell him that Mr. Percy has been here again, and he probably wishes to tell me about Queenie Perth. 


\section{CHAPTER XII}

PLANTING BEFORE THE WALL

DURING this planting-time Joseph has not neglected to provide decorations for our wall, in spite of the many other things that have needed attention. Some fine day, he tells me, this wall of ours will be entirely covered with foliage, owing to the little, straggly things he has lately set out by its side. Besides the climbing nasturtiums and the crimson ramblers, he has planted a number of Virginia creepers, two honeysuckles and a clematis paniculata. With the exception of the nasturtiums, these are all perennial vines which will keep on living from year to year. There are, of course, such beautiful annual vines as the Japanese morning-glory, the moonflower, Japanese gourd, passion-flower, and others, which Joseph might have sown, and which perhaps would have astonished us by their abundant growth during this one season. He crossed them off from his list, however, thinking it best to have vines that need not be renewed every year, even if they make him wait longer before he sees them well grown. 
As far as he can, Joseph is making his garden of plants that know pretty well how to take care of themselves. He wishes them, as I have already said, to be like the wild flowers in the woods, which return each year in definite seasons.

It was not for their flowers that Joseph planted so many Virginia creepers along the wall, since these are insignificant, but for the leaves of the vines, which, from the time they unfold in the spring until they turn a brilliant crimson in the autumn, are always beautiful. These Virginia creepers, therefore, will form the foliage of the wall, while the nasturtiums, the clematis and the honeysuckles will give it flowers.

Mr. Percy advised Joseph to plant the native Virginia creepers, and together they found the vines by the edge of a near-by wood. Afterwards, Timothy went with wheelbarrow and spade and took them up. Had we bought them at the nursery, we could have had no better specimens than these which were found growing wild. Joseph had often seen poison-ivy in the woods before he came to the Six Spruces to live, and he thought he was being urged to transplant it to our wall; but $\mathrm{Mr}$. Percy, by opening a miniature leaf, soon showed him that, though the two vines resembled each other, the Virginia creeper has five leaflets, while the poison-ivy has but three.

We were discussing this point of difference between the two vines, when Queenie Perth surprised 
us by saying: "I know poison-ivy has three leaflets because ivy has three letters in its name. It can never poison me or Rosamond. We stay too far away from it."

Rosamond is Queenie's doll. In some ways Queenie is wiser than one would expect, while in others she is more babyish than she should be for a girl nearly nine years old. What she had said this time about the three leaflets of poison-ivy had quite fixed the fact in my mind. As yet, I have never gone through a season in the country without being severely poisoned.

As our vines grow old and sturdy, Joseph plans to put up poles by the side of the wall, on which they may twine skyward. These, I think, he especially wishes for the clematis paniculata, with its masses of sweet-smelling, white flowers. The idea seems attractive to me also, as the stupid straight line of the wall will then be broken. But this is one of the unfinished things in our imagined garden when all the seeds and plants that we have set out are grown.

Mr. Percy knows quite as much about vines as he does about ferns. He was delighted to see that the creepers he had suggested transplanting so soon showed signs of having taken good root. $\mathrm{He}$ said the form of the rose garden was an inspiration. It suited the triangle better, he thought, than if it had been circular, square or even long and narrow. Perhaps it is because he has no sisters that he did 
not know until we told him that it was in the shape of a fan. He then said: "Why, yes, to be sure." That very evening he sent me a little fan from Japan covered with pink and red blossoms. They are not roses. Perhaps they are peach blossoms. The fan is unusually pretty, and I really think my rose garden will have somewhat the same appearance.

We are sorry that the Easter holiday is over, for Mr. Percy has gone back to college. When he next returns, however, it will be for the long summer, when he will be of great help to us in beautifying the Six Spruces. He never speaks as his father does about our Aunt Amanda. We are sure he wishes us to make the old house look as if it peeped up among flowers. $\mathrm{He}$ is not content that we should have a garden only about the triangle. He wishes us to make wide borders across the front and along the sides of the house and to plant them mostly with scarlet geraniums. As the house is painted buff, he would especially like the effect of these flowers against it. Perhaps we shall try to carry out his wishes next year; but already we have planned to do quite as much as it will be possible for one small boy to take care of. Later Timothy will be coming only once or twice a week. The rose garden I shall look after myself.

The work of gardening, we find, is not all over when the planting is completed. There are then 
worms, spiders and beetles to be overcome, and watering to attend to during dry weather.

We are learning to have a respect for even toads and garter-snakes, since they eat many of the harmful insects which make their way into gardens. Formerly I shuddered at the sight of these creatures, and even now I cannot regard them with much peace of mind. But, after all, the great desire when one has a garden is for perfect flowers, and, in order to secure them, such disagreeable things as snakes, toads and manure piles must be encouraged.

The wrens that live in one of the bird-houses have become so accustomed to seeing Joseph and me about the Six Spruces that they no longer mind our presence. They also are friendly with Mrs. Keith. In the morning, evening, and many times during the day the male bird passes swiftly across our back veranda, perches himself on a bit of cornice near its roof, and, lifting his head high in the air, sings us his sudden and spirited song. It is a song that I cannot imitate. Yet the bird gives me every chance to learn his lay, repeating it over and over again. A most happy creature he seems, not letting the thought that he will soon be the father of five or six hungry fledglings weigh heavily upon his soft brown shoulders.

The grackles, on the contrary, which made their nest in the old pine tree near the moist point of the triangle, never come near the house, and sing only 
in squeaky voices. Joseph has found out they are likely to eat a great many grubs that might do harm to the flowers; and that on occasions they eat the eggs of other birds. This is a trait not to be respected in the grackles. Yet I like to watch the male birds in their metallic-looking black coats. I have noticed that they are often iridescent like coals and of a remarkable shiningness. Timothy has warned us strongly against these birds, saying that they do no good to the farmers' corn. Still, there are so few farms near us in Nestly that Joseph may some time have to give the grackles some grains in payment for the grubs they destroy.

We have found that, even with the best intentions, there come moments of real discouragement in gardening. Except for the general air of tidiness about the Six Spruces and the triangle, and the fine symmetry of the flower-beds, there is really, so far, little to be seen for all the work that has been done. Were it not for the fact that Hope whispers to us, and we believe the seeds are sprouting and the little plants growing, we should hardly have the courage to go on. The cold, wet days that come after the middle of spring especially dampen the spirits.

When this discouragement falls upon me, I tell Little Joseph it is time for us to go to the woods and see what is blossoming there in Nature's world of wild flowers. Somehow, I cannot think the flowers that live in a garden and have to be sown 
and watered are as real as those that come up without any assistance from man.

In our woods, the leaves are now well unfolded. The hepaticas, bloodroots and anemones have ceased blooming, and even the few little yellow violets that we found are making their seeds. Two spring orchids are aglow with their enchanting flowers. They grow in a secluded, deep part of the wood near where we hear a whippoorwill. This bird often lives in the hidden haunts of orchids, and seekers of these flowers sometimes find them by following his melancholy notes, in much the same way that men hunting tigers locate them by the cry of the peacock.

This year for the first time we saw wild ginger. Mr. Percy showed it to us the day before he went back to college. Its leaves are rounded and appear like velvet. They cover the ground in great mats. But the flower of wild ginger does not like to be seen. It prefers to hide its head in the earth, and lies under the leaves closely hidden in its dress of green marked with purple. Joseph and I should have missed seeing it altogether had not Mr. Percy slipped his hand under the plant and lifted the Hower up to our sight.

He said that wild ginger would be a delightful plant for our wood-border, since it likes the shade so well. As soon as its seeds were sown, we determined to have Timothy take it up in large blocks and transplant it for us, just behind the hepaticas 


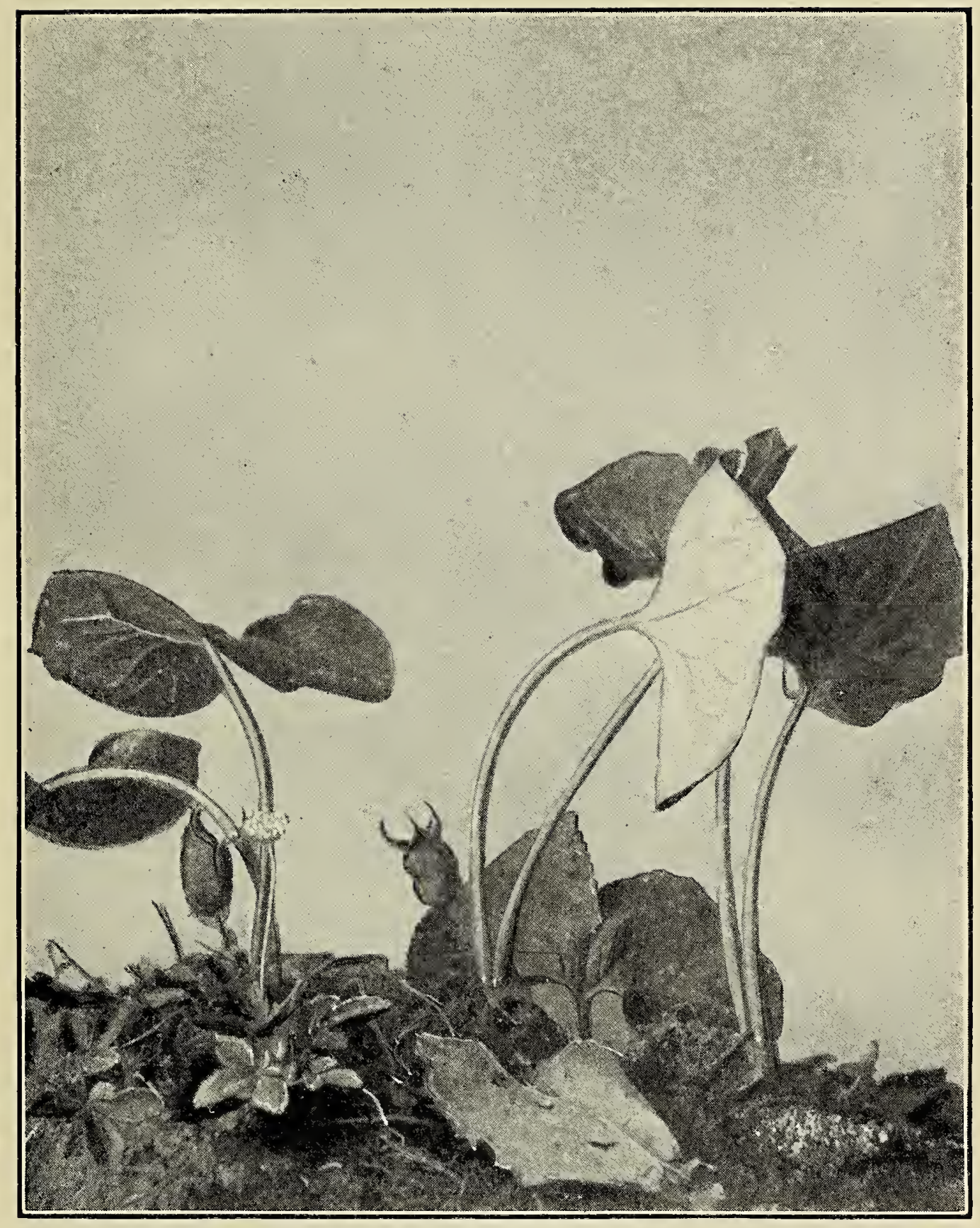

PLATE XIII.-WILD GINGER 

and higher on the slope. Some day the woods may have a thick, green carpet of its soft leaves from early spring until late in the autumn. We hardly could expect to find another ground cover for the coppice, which, like the brave, sturdy hepaticas, holds its green leaves throughout the winter.

Whenever we transplant wild flowers, Mr. Percy says we must be sure to take enough of them to establish what he calls a "permanent colony." Just one or two wildlings set in or near a garden have a frightened, not-at-home look, while numbers of one kind together usually retain their wild charm.

Mr. Percy told us, moreover, that transplanting wild flowers was something he had long wished to do himself; but that there was little opportunity for experimenting at such a formal place as Nestly Heights. Naturally, Little Joseph and I were glad to let him do whatever he wished in our woodborder. In fact, we grew quite used to his help, and now miss him sadly since he has gone away. In the rose garden, however, I shall manage things quite after my own mind. There not even Little Joseph is to be allowed to pull a weed. 


\section{CHAPTER XIII}

JOSEPH COMPLETES THE PLANTING OF THE GARDEN

OW that May has been here for a fortnight,
I recall how busy Joseph has been setting out numbers of perennials that he bought from the nursery of Nestly, and others which were given him by Miss Wiseman and Mr. Hayden, who have been dividing some of their old, well-grown plants. $\mathrm{He}$ has made an effort to complete the planting of his garden, with which, however, he seems never to be quite finished.

Almost every day Joseph hears that some seeds that he has already sown should be planted again now, and also later on, in order that throughout the season he may have their flowers in succession. He knew, before starting his garden, that farmers did this with peas and other vegetables, but he did not realise that the same thing was to be done with flowers. Here is another difference between wild flowers and those in a garden. When the former have bloomed and sown their seeds, their work is over for the entire season. Mother Nature allows 


\section{JOSEPH PLANTING THE GARDEN 97}

them then to rest snugly. But gardeners have learned to sow and resow the seeds of cultivated flowers, that they may not pass out of sight with their natural season of blooming.

Joseph hears that there are little tricks of nipping off flowers before they form seeds, and, by so doing, keeping the plants blooming longer than their natural season, for, above all, a plant desires to make seeds. The flower which is seen and beloved by people is really only a means of making the more important seeds, which then the plant contrives to sow in order that its existence may be continued from year to year. It seems a little melancholy to me to keep the plants longing to make and sow their seed until, perhaps, they are caught by the frost without their object in life having been accomplished. Still, a garden whose flowers had early ceased to bloom would not be pretty. In fact, it is gardeners now who attend to the reappearance of plants year after year, by sowing the seed, and Joseph finds he must follow their ways, although at times he may think them unnatural and heartless.

The most important perennials that Joseph bought, or had given to him, were phloxes, golden glow, larkspurs, irises, and chrysanthemums. In addition to those he already had, and with his annuals, the garden will be started very well.

I cannot describe every place in the triangle that he has planted. He has placed each plant where 


\section{8}

he thought it was likely to appear to the best advantage. This is something which every one who starts a garden must think out for himself. The important points that Joseph has tried to remember have been the colours of the flowers, the heights to which the plants were apt to grow, and the necessity to set them in places that gave them the right exposure. Some plants are sun-loving, others delight in shade; many have a bold, brilliant look, while others are shy and modest. When planting, therefore, Joseph has thought of the character and habit of the plants rather than the appearance of the little green things themselves when he set them in the soil.

It is too bad that we have no peonies in our garden this season. They, however, start with the first warm breath of spring, and so do best when planted in the early autumn. As soon as that time comes we shall get roots of large plants, which then perhaps will give us great, toppling blooms the following spring. I hope to persuade Joseph to buy only white peonies, although I know the dark crimson ones open earlier, and the double pink ones are very beautiful. Still, the white ones are my favourites.

In a garden near our old home, Joseph and I used to go early each spring to see the peony buds after they had worked their way up through the earth. They always had the round, shining look of little balls, until later when they burst into great white 


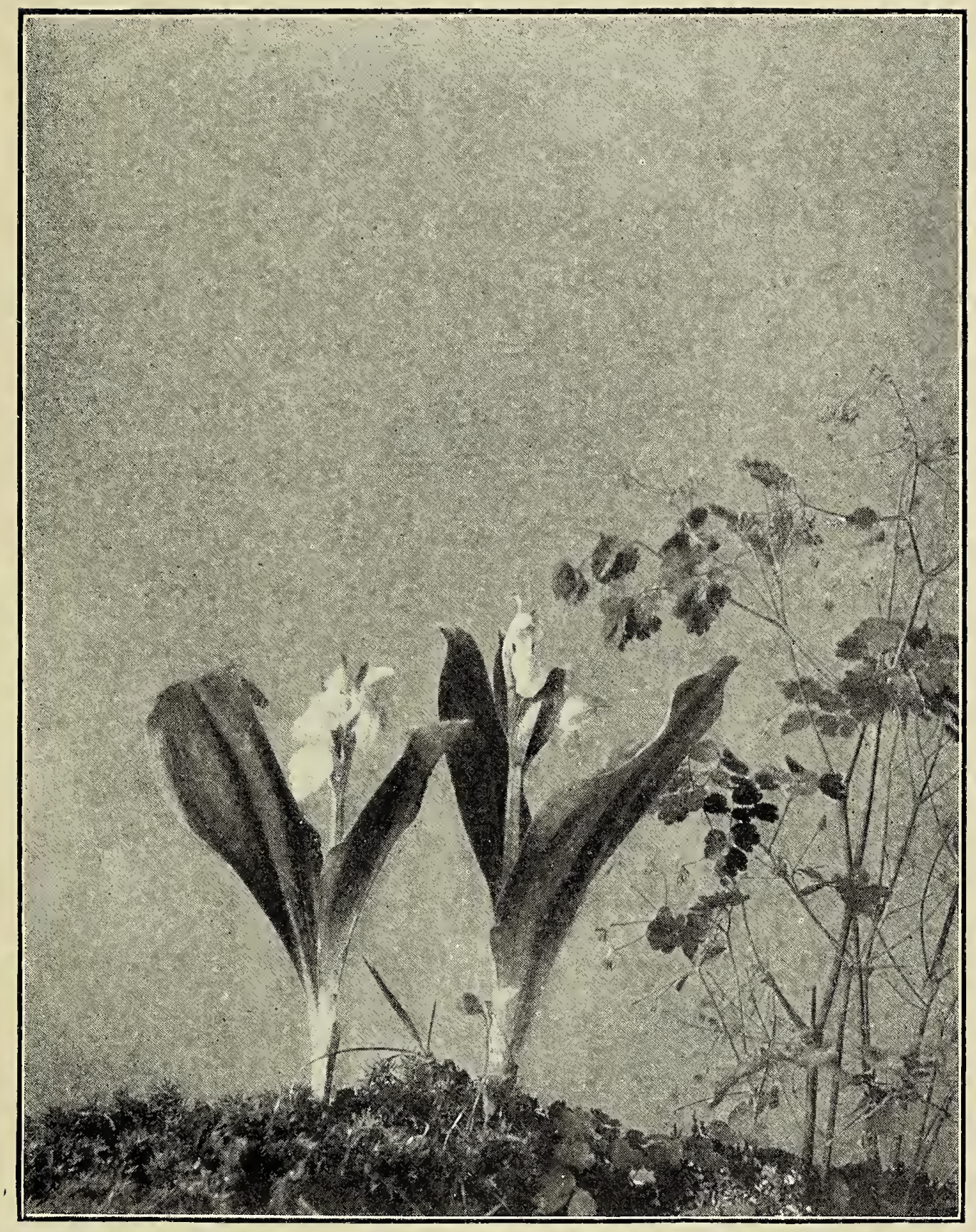

PLATE XIV.-TWO SPRING ORCHIDS 

flowers. In that old garden, I remember the plants had not been disturbed for years, but had grown very large, reappearing regularly with the spring.

Over at Miss Wiseman's, the peonies are planted at the ends of several borders. I wish ours to be set in a bed by themselves, not far from the wall, near the point of the triangle. This year, however, we will use it for annuals or other plants that can be easily transplanted when the time comes for putting in the peony roots.

Both Miss Wiseman and Mr. Hayden have given us columbines which will soon begin to bloom. Those that Joseph sowed in the seed-bed will not bloom until next year, since they are perennials. We shall save a space for them near the others, because, as with peonies, I think they look best when kept by themselves. But Miss Wiseman has them in the same border as her peonies, poppies, phloxes and other kinds of flowers.

Perhaps I am wrong in some of the ideas I put into Joseph's head. I do, however, much prefer to see flowers of the same kind kept closely together to having them scattered about among those of a different air. Near them, flowers that bloom earlier or later can be grown. At least, we intend to plant our garden after this idea. If it then turns out a failure, we will give in and follow our neighbours. Mr. Hayden thinks we are very bold, and, perhaps, a little ungrateful, not to allow his landscape gardener to keep us, as he says, in the 


\section{JOSEPH PLANTING THE GARDEN}

straight and narrow path; but, if we did so, the fun of making our own garden would be spoiled for Joseph and me.

At Nestly Heights, not one of the family ever sows a seed or ventures to pick a flower; even the birds are shy about building their nests there.

About the triangle, these gay creatures appear more at home every day. The wrens, the bluebirds and the grackles, which came first of all, have now been joined by many friends, while robins, song-sparrows and chippies have come in great numbers. Almost every day we find a nest not seen before. Naturally, the builders make a great fuss and appear to be in actual terror as we draw near to examine their work; but, when they see that we go away, leaving everything undisturbed as soon as our interest is satisfied, they settle down quietly again. The next time we visit them, they appear less frightened.

On all sides we have heard that no garden should be without phloxes. Joseph, therefore, bought three dozen plants before he knew that others were to be given him. They are very easily cultivated, and, as they can be separated at the end of three years into three times the original number, we think them a good investment. Phloxes come into full bloom about the beginning or middle of July, when many other flowers have had their day and are busy making seed. Miss Wiseman says her garden at this time is fairly aglow with them. In 


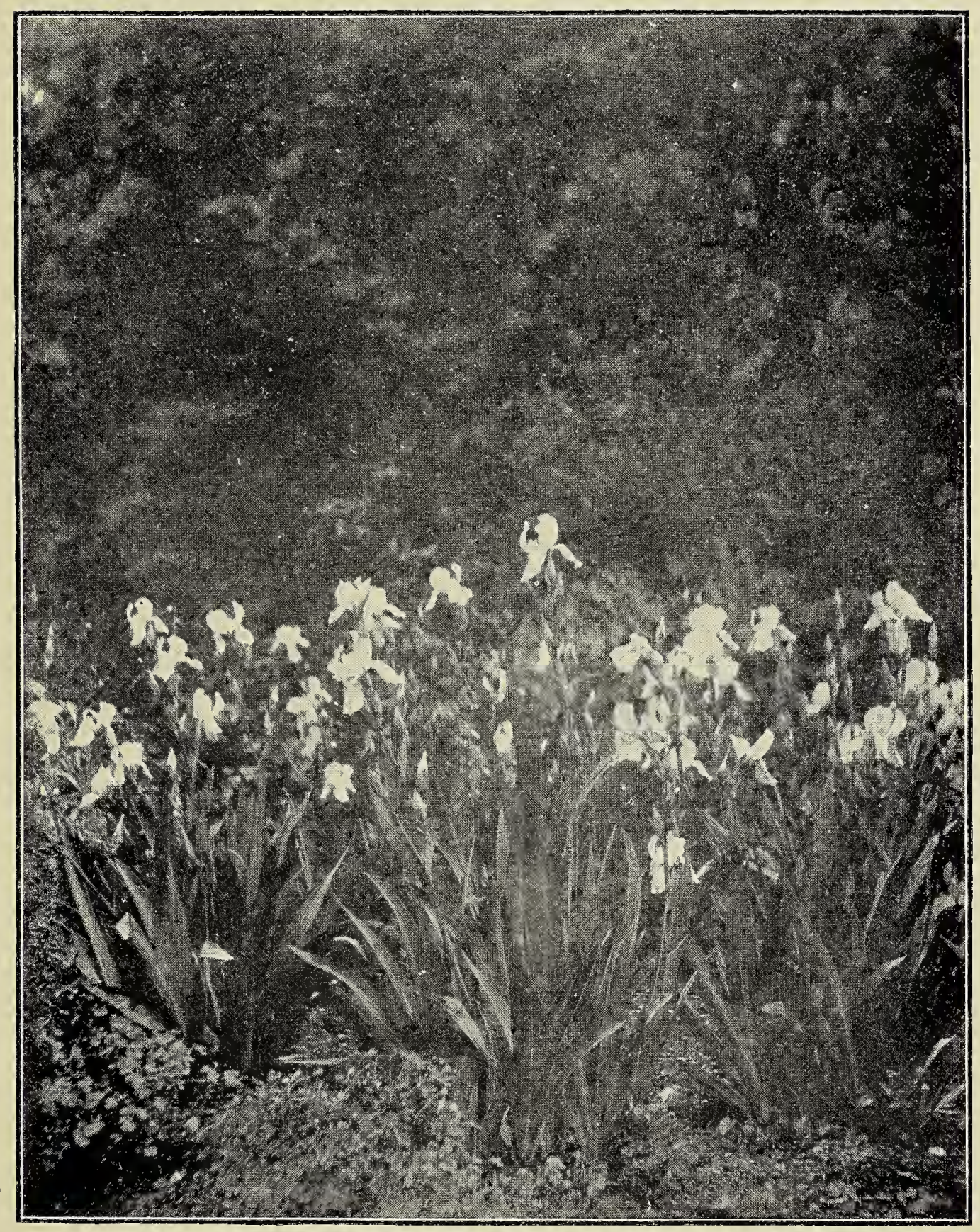

PLATE XV.- "BLUE FLOWERS THAT SHOULD BLOOM FOR US SOON" 

fact, phloxes have been very much cultivated of late, and many new varieties of them have become known. It is quite bewildering to read all their colours on Joseph's labels. I rather think we shall have them in every shade and combination of colour except yellow. As yet I have not heard of a yellow phlox. The prospect of such a medley of colours is bewildering, and the only suggestion I was able to give Joseph about them was to put them in ground where there would be nothing else to flower while they monopolised attention.

As I look at them set here and there about the triangle, I think that their stiff stalks and prim little leaves are decidedly ugly. Surely, they should bear beautiful heads of bloom to make up for this defect.

Our ideas about the larkspurs were more definite. I especially love these flowers. Joseph bought only plants that would bear blue flowers, and he planted them in among the meadow-rues which he and Mr. Percy took from the woods. The flower of the meadow-rue is so insignificant as scarcely to be seen by people who are not botanists, while its foliage is exquisitely shaped and of a bright, beautiful green. The larkspurs raising their spikes of fantastic blue flowers among it will be most lovely. Mr. Percy helped Joseph transplant the meadowrue; and, so far, not one of the number has shown the slightest sign of dying. The work was much 


\section{JOSEPH PLANTING THE GARDEN}

the same as that of bringing the ferns to the moist point.

I love blue flowers, and invariably urge Joseph to buy them to the exclusion of red and pink ones. I cannot tell why this should be so. Roses are my greatest favourites, and they are never blue.

The first blue flowers to bloom for us will be the irises. Joseph bought German and Japanese varieties, since both bear beautiful flowers, and the Japanese begin to bloom just as the Germans are fading. We chose them also because they are hardy, needing neither care nor winter covering, nor was an especial bed prepared for them. Joseph simply put their long roots deeply in the turf at the moist point of the triangle. They are plants that dislike dry weather and dry soil. We did not have many this spring; but irises increase very rapidly, and in September, which really is the best time for planting them, he will add to the number.

Once, when driving along a road in May, Joseph and I stopped beside a moist meadow completely covered with wild blue flags. The dusk was gathering. Among the tall leaves Joseph imagined that he saw a little gnome blowing out his cheeks to keep the moths away. The coat he wore was made of leaves, although not those of the irises. I could not see the little fellow myself, even though Joseph pointed him out walking through the meadow, and showed me the butterflies circling 


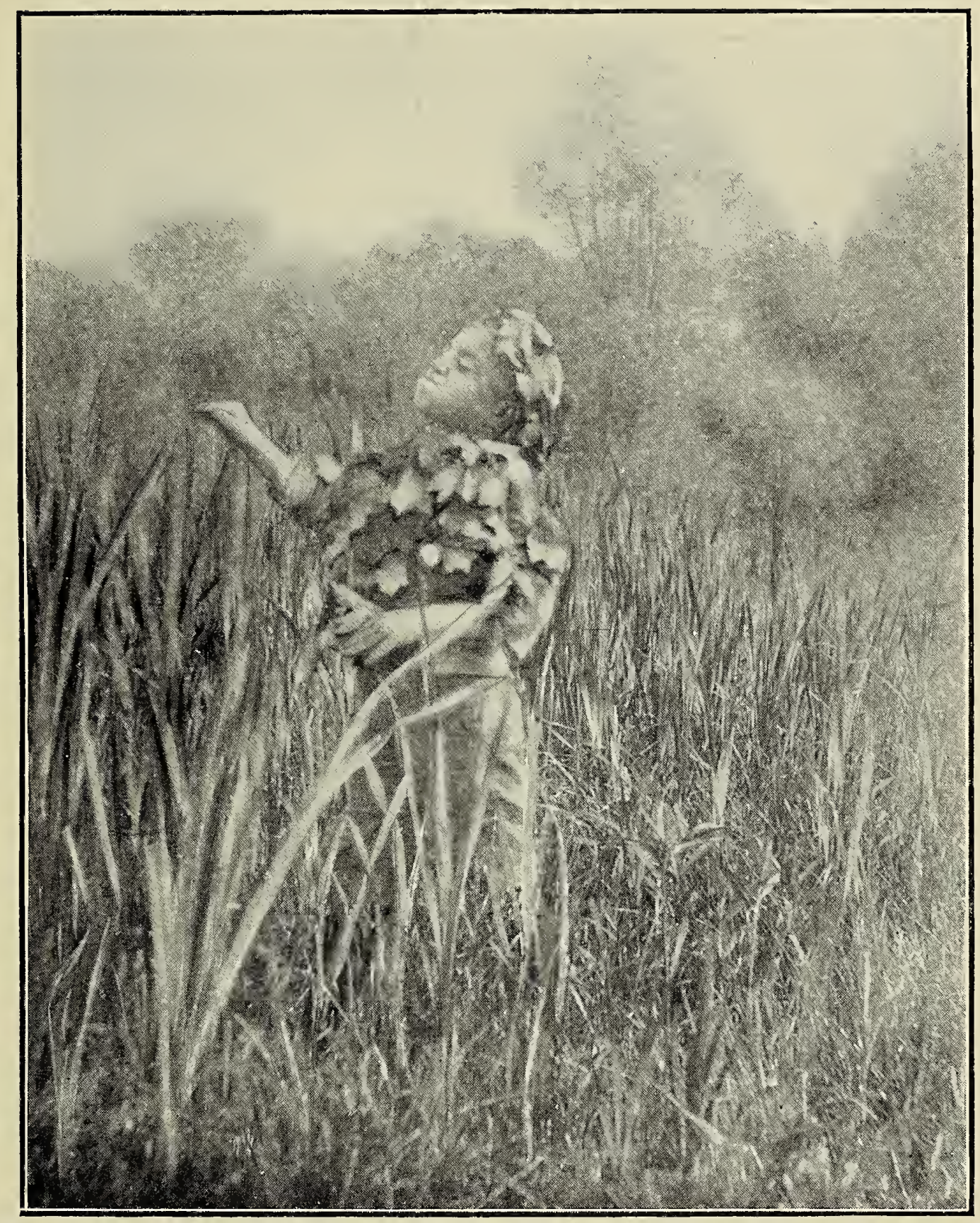

PLATE XVI.— "BLOWING OUT HIS CHEEKS, AND BREATH TO KEEP THE MOTHS AWAY" 

about his head. Often we have both been reminded of that meadow.

The cultivated irises will bear larger flowers, and have a more complex form than the wild blue Hags. If they make the moist point of the triangle half as pretty as the meadow, perhaps Joseph's gnome will find them out.

The golden glow was set in front of the wall at the very end; farther down, in fact, than the hollyhocks. The former grow so high, and are so vividly yellow, that I think they should be looked at from a distance.

Then there are the little plants of hardy chrysanthemums that Joseph has set out. These are most important, since they give us flowers last of all. During the summer, they will appear as foliage plants, because we will keep their buds nipped off to prevent their blooming early. The leaves of chrysanthemums are a soft, ashen green, and therefore look well as a background for other flowers.

The number of plants that Joseph has already set out about the triangle is wonderful to me. I feel sure his back must ache. But, in spite of all the work that he has done, I have thought of other flowers for which I am pining. Heliotrope is one of them; but as yet I have said nothing about it to Little Joseph. 


\title{
CHAPTER XIV.
}

\author{
MAY TIME
}

FOR the last few days Joseph and I have done $F$ little in the garden. We have been meditating and watching things grow. Besides, we have seen a great deal of our neighbours and their gardens.

May in the country is surely as lovely as June. The roses have not yet bloomed; but a wealth of other flowers have let out their petals. At Miss Wiseman's, the hardy border is a lively sight with irises, columbines, azaleas, rhododendrons, and the prettiest little phlox Drummondi edging it all about. It is the early crop of this phlox that shows in May: the main one will not come on until July. As we see it at Miss Wiseman's, lying a mass of bloom on the ground, its colour is a clear and brilliant magenta. It has bewitched Joseph, who tells me he intends to have a quantity of it next year about the borders at the Six Spruces. It not only comes up readily from seed, but resows itself abundantly. Indeed, it is not at all difficult to grow. 


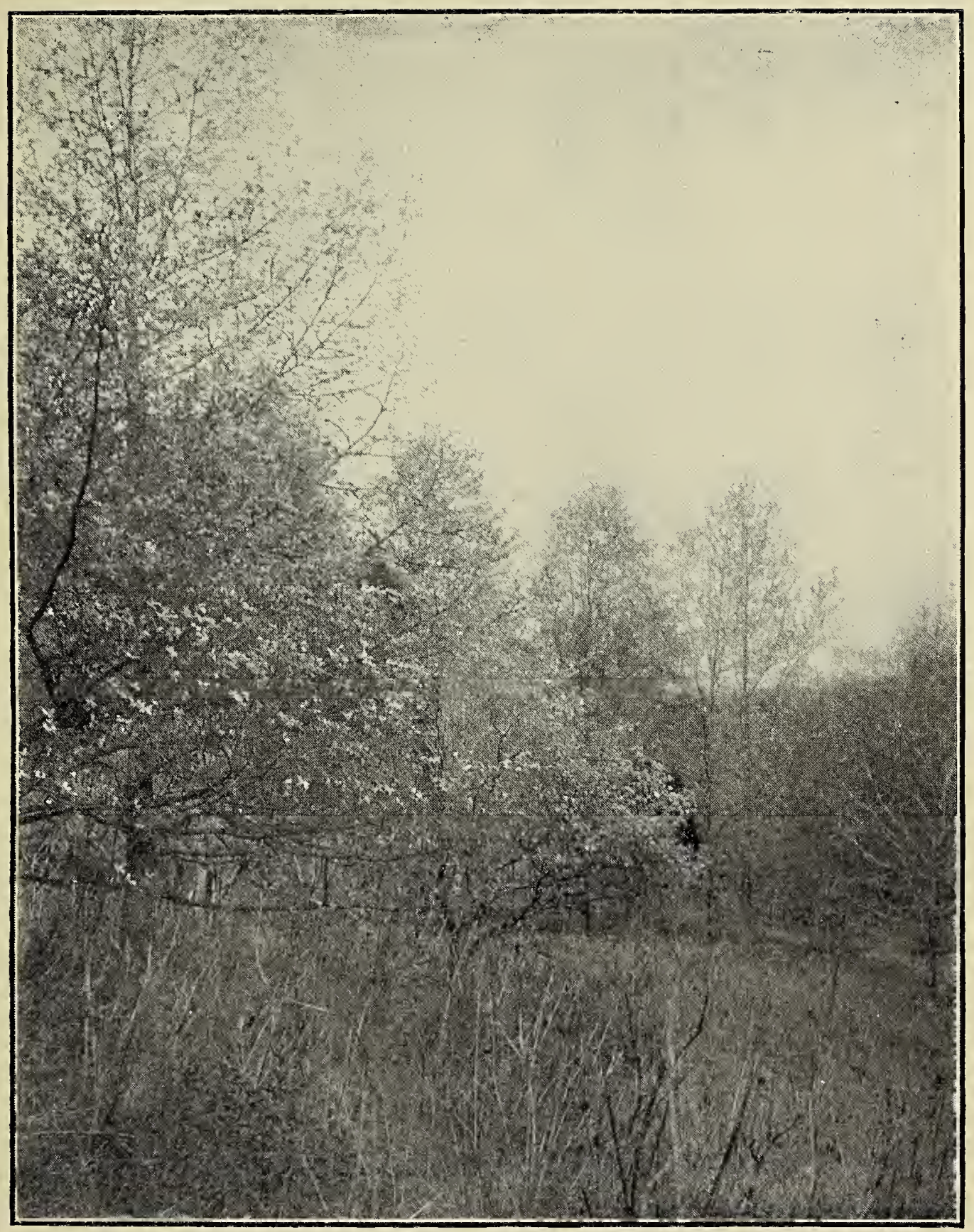

PLATE XVII.— "MAY IN THE COUNTRY IS AS LOVELY AS JUNE" 

We already have a small quantity of phlox Drummondi, it being one of the annuals Joseph sowed in the seed-bed. The plants that we have raised, however, are very meagre in comparison to those at Miss Wiseman's. Yet I am glad our plants are white or yellow, instead of magenta.

Since Joseph and I have learned a little about raising flowers, we have developed a gift for criticising gardens that are old and highly cultivated. Already I have whispered to Joseph that I do not think Miss Wiseman is very sensitive concerning the colours in her garden. I should never be content to have the magenta phlox Drummondi bordering beds of pink azaleas, nor should I plant it in front of red columbines. In fact, there are not many places in a garden where bright magenta would please me at all.

I notice but few border plants of yellow in our friends' gardens, and, therefore, if our seedlings of yellow phlox Drummondi turn out a success, I shall urge Joseph to keep to that colour to the exclusion of white, magenta or dark red. At Nestly Heights this phlox is showing magenta the same as at Miss Wiseman's. No doubt fashionable gardeners like the brilliancy of this colour.

Mr. Percy has been home for over Sunday. I was telling him how beautifully I thought this little annual phlox spread itself about the garden beds like bands of ribbon. 
"But you would prefer blue ribbon?" he commented.

I replied that this phlox did not come in that colour.

"Then have quaker-ladies," said Mr. Percy. "Even now, it is perhaps not too late to secure them."

He urged us to go with him to a moist meadow some distance back of the Six Spruces, where great patches of the ground were turned blue by tiny flowers with yellow eyes, their small leaves clinging as closely to the ground as moss.

"These are quaker-ladies, or bluets," said Mr. Percy. "Can you not see what a lovely band of blue they would make about your flower-beds?"

"But would they live," Joseph asked, "if we transplanted them now, when in flower?"

"If we did it cleverly enough," Mr. Percy answered.

Later in the day, we returned to the place with Timothy and all necessary implements. We then moved the quaker-ladies in long, narrow blocks of earth. Their roots did not extend very far down, and I felt sure that the little ladies knew nothing at all about this being their moving day. Fortunately, Joseph had made no plans for a border-plant about the bed near the point of the triangle; so there we set the blocks of quakerladies, which formed a band of soft blue about the whole. We gave them a long, gentle spraying, 
and, as they never once drooped their heads, we concluded that they at least would live throughout the season. Timothy had to return again to the meadow before we had enough plants to complete the border.

Next year, perhaps early in May, Mr. Percy says, they will reappear in their sprightly fashion in the border. This season is slightly backward. Joseph and I felt that we had done a good day's work to secure a permanent and beautiful blue plant for the crescent-shaped bed.

"It is a border," Joseph reminded me, "that they have neither at Miss Wiseman's nor at Nestly Heights." This thought pleased him immensely.

Mr. Percy never seems to be afraid to handle or to discuss wild flowers. He takes less interest in the cultivated ones. One day he told us something interesting about trailing arbutus, which has vanished from this neighbourhood because people have picked it so ruthlessly. "Many books and magazines," he said, "state that it is very difficult to transplant this flower and that a permanent colony of it has nowhere been found in cultivation. I wish the people who hold this opinion might see the wild-flower garden of a friend of mine who has a large and important colony of trailing arbutus transplanted from the open country. It showed not the slightest reluctance to live, because it was taken up in large blocks of considerable depth. 
Wild flowers," Mr. Percy continued, "are truly eager to grow."

He then told us about two Jacks-in-the-pulpit which he himself had taken up from the woods in May, not very carefully, and which later he planted in a poor and clayey soil, quite different from that of the rich, loamy wood. He had transplanted them in defiance of all recognised conditions.

"Yet they are still living," he said, "and the lady Jack has borne fruit every year."

Naturally, Mr. Percy had transplanted a lord and a lady Jack, as the green-striped and the purplestriped Jacks are respectively called. If he had transplanted two lords, or two ladies, then there would have been no fruit, since fertilisation could not have taken place.

After this conversation, Joseph thought that it would be a good idea for him to transplant a number of lords and ladies to our wood-border, where the soil and the shade would suit them exactly. But he planned to do it late in the autumn, since for him they might not be willing to go against all their traditions as they had for Mr. Percy. I think the spirit of the woodlands is really in Jacks-in-thepulpit.

Before this spring, I had never realised how exquisitely lovely were daffodils and jonquils and also narcissi. They have all passed bloom now, but at our neighbours' there has been, until lately, a wonderful showing of them. The especial names 


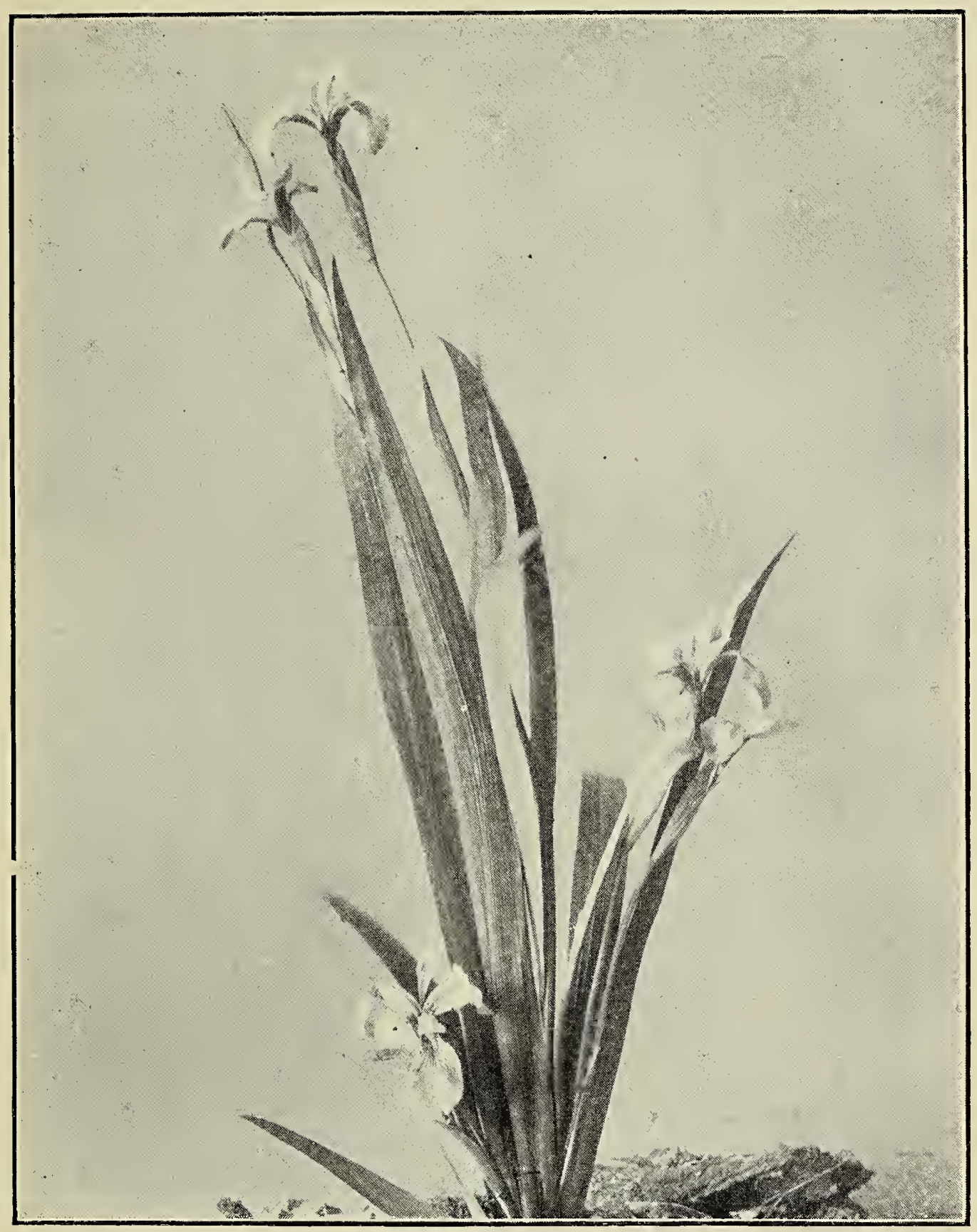

PLATE XVIII.-THE WILD BLUE FLAG 

of these bulbs are all now jotted down in Joseph's note-book, to be again deeply considered when it comes time for autumn planting.

Among other things that Joseph has attended to recently has been the setting out in the garden of the little plants that he raised in the boxes under the camera plates. The baby's breath has now become neat-looking little plants, which have been thinned out and set in the soil twelve inches apart. I have never seen this plant in bloom, so I shall still have to wait a while to know much more about it. In the catalogue we read that its flowers would be white, or rosy, and that the plants would be nearly covered with them.

The ten-weeks stocks are now also set out in the garden, looking slim and dignified with a space of twelve inches between them. We expect these flowers to be white, pink and purple. The white ones should bear double blossoms. I feel sure we shall be satisfied with these stocks, for they already have a vigorous look, and I like the soft shade of their foliage. As their name implies, they will last in bloom a long time.

The cardinal-flowers have been slower in starting than the others, and even now are not large enough to transplant.

It has proved quite a success sowing these seeds in the boxes indoors, for the plants are surely now better grown than if we had waited until May to put them in open ground. The experiment was 
also fun for Little Joseph. In fact, I think he cares more for these plants than for any others in the garden. He feels they are more his own, since he has taken care of them so long and watched their leaves forming from the time they first appeared above the earth. In observing them, he has learned something about the building of a plant, and found out some of the ways of the plant world more accurately even than by reading "An Ambitious Boy's Garden."

We have no Weigelia shrubs at the Six Spruces; but at nearly all the other places about, the pink varieties are coming into bloom, appearing like heavy, coloured clouds. Especially at Miss Wiseman's, I think they will be very beautiful, because there the shrubs are all old and large. Nestly Heights is a new place.

At the edge of our wood-border the dogwood is in bloom, giving the appearance of gay company. And to our surprise one of the wild dogwood trees is sending out flowers of salmon pink. They are not merely pinkish from fading, as many white blossoms become, but are really pink and have been so since the day they unfolded. Timothy tells us that our Aunt Amanda took an interest in this tree and felt proud of it, because it was the only one of the kind she had seen or heard about in this part of the country.

Our three lilac bushes are also in bloom. When Mr. Hayden came to see us on Sunday, he said, not 


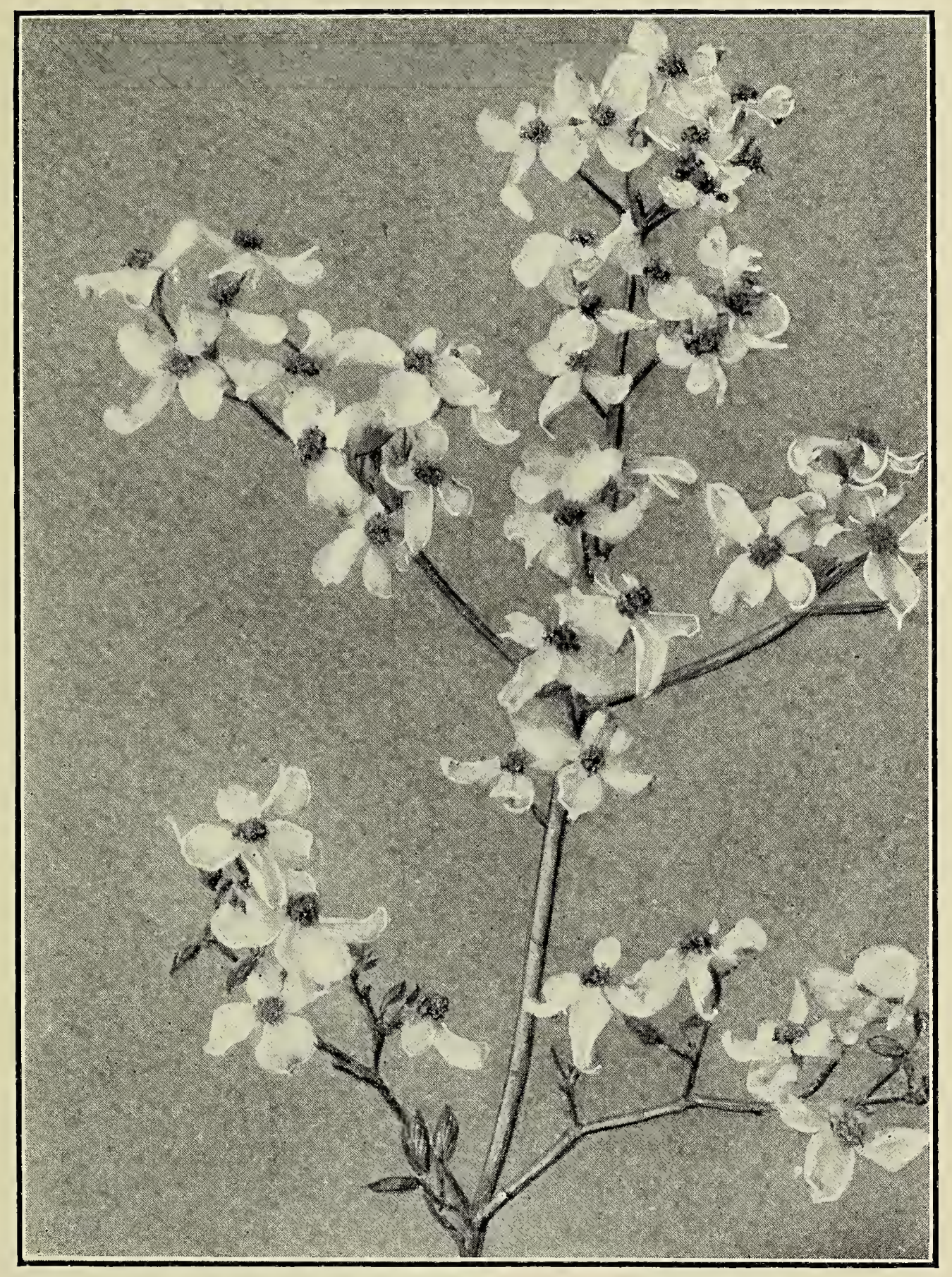

PLATE XIX.-PINK DOGWOOD 

in the way of a spring zephyr, but like the wind before a squall:

"Now I know where I am. The scent of those three lilacs makes me feel the presence of your Aunt Amanda. Take me into the parlour, please, and let me sit on the haircloth sofa."

We took him into the parlour, where he was surprised to find the favourite sofa covered up with brocade.

"Dear me," he said, "there is nothing in this world so sure as change! Are you not afraid the light streaming in at those windows will fade the carpet?"

I answered that the carpet was already faded, and that we liked the air and sunshine.

"What about flies?" he asked. "Your Aunt Amanda never let one come within her walls."

I did notice then that there were a number of flies about, and felt it was perhaps a sign of poor housekeeping.

Afterwards, Mrs. Keith brought in tea, of which Mr. Hayden drank two cups, saying it was excellent. He still continued to tease us about the changes we had made at the Six Spruces.

I asked him if he had heard Joseph play his violin; for this is something my brother can do even better than plant a garden. Mr. Hayden answered:

"Dear me, music in this house on Sunday!"

Then Joseph played as he does on Sunday after- 
noons, when he chooses only pieces which fit the mood of the day. Mr. Hayden was less brusque while Joseph played than I had ever seen him. He praised him heartily, saying that long ago when he was a boy he used to play the cornet; but that finance and the strenuous life had made him forget the way of it.

He loved music, he said, almost as much as he loved flowers. 


\section{CHAPTER XV}

\section{ABOUT WILD AND CULTIVATED FLOWERS}

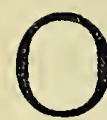

NE of the fortunate things about garden flowers is that when once they have unfolded, they last long enough for us to know them well. The cultivated flowers make considerably longer visits than the wild ones from which they are developed. Our irises, that is, the German ones, are still in bloom, looking finer every day; but the wild blue flags which they so much resemble are now quite faded.

This also I have noticed with columbines. It was about the first of May when we began to find the wild ones deep in the shadow of the woods and nodding over high rocks. A little later those which Miss Wiseman gave us began to bloom in the triangle. Now the wild ones are making seeds, but those of the garden are astonishing us every day by the added flowers they unfold, and by their lovely colours and their fantastic shapes. It seems to me that these cultivated columbines have learned every trick of variety. I can scarcely think of a colour in which they do not appear. There is a 


\section{WILD AND CULTIVATED FLOWERS}

double white one tinged with pink, like the inside of a shell; another is blue, with a paler, almost white centre. This one is flatter in shape and larger around than most of the others. I can hardly tell which of these columbines I like best, they are all so pretty.

Hybridization, a long word at the tip of gardeners' tongues, which means the crossing of plants and production of new varieties, has had a great triumph with columbines. In gardens they have become vigorous plants, standing up straight to a height of three or four feet. No doubt, in producing so many forms and colours of columbines, gardeners have thought that they were greatly outstripping those that dwell in the woods. But as I recall the wild one with its red and yellow bell nodding from its wire-like stalk, I love it best of all. Still, it would not be as showy in a garden as the cultivated varieties. It does not like the full blast of the sun and the mixed company of the great world. It prefers to stay in the peaceful, shady woods, where the ruby-throated humming-bird may find it and sip of its nectar.

Some time ago Mr. Percy and Little Joseph transplanted a number of wild columbines, or rockbells, as Queenie calls them, to our wood-border. $\mathrm{Mr}$. Percy recognised them long before they had opened their leaves, when to Joseph and me they looked as if they might turn out to be ferns. He then chose small, young plants for taking up, as 


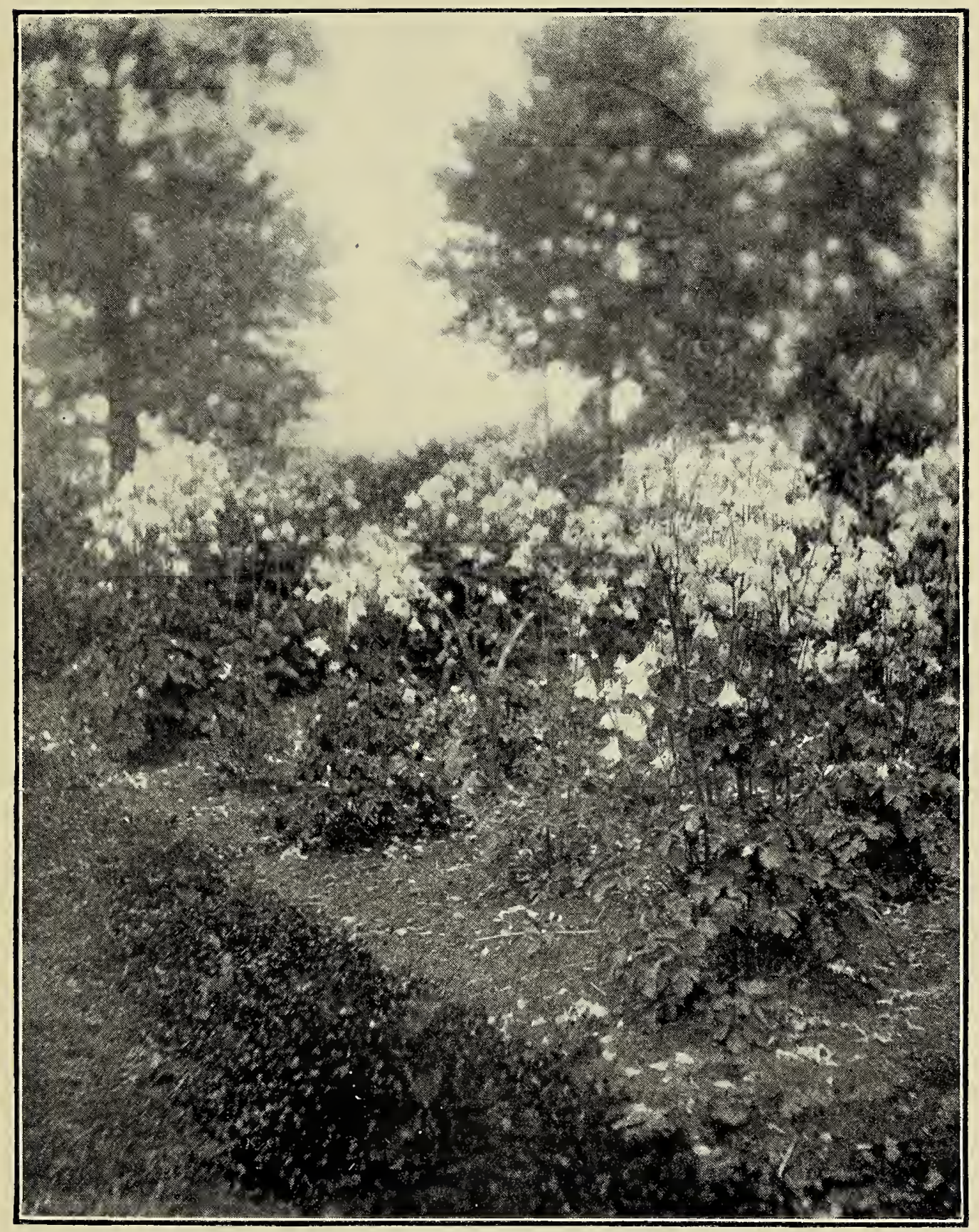

PLATE XX.-COLUMBINES 

the older ones have long, thick roots, which make the success of transplanting them somewhat doubtful. That day they brought about twenty columbines to the wood-border. If next year we get twenty more, and those that we have sow a few seeds, we shall have a colony as enchanting as the one Mr. Percy told us about. The columbines there have not been disturbed for years, he says, and they are now a sight for a king.

Another wild flower that we have transplanted is called false Solomon's-seal, or wild spikenard. It blooms in the woods at the same time as the columbine. Its stalk is long, with large leaves coming out from it on either side, and at the very end there is a great, pointed bunch holding myriads of fine, sweet-smelling white flowers. The stalk of false Solomon's-seal always leans over a little, instead of standing up straight.

We have planted it where the wood-border slopes slightly, so that it now appears as though leaning over towards the bank. Here, Mr. Percy says, it will be very beautiful when once it is well established. It will, moreover, need no further care.

This reminds me of another difference between wild and cultivated flowers which neither Joseph nor I can understand. The wild ones are visited by bugs and beetles and insects of many kinds, which harm them but slightly. In a garden, however, these insects become pests, biting and molesting the plants, and greatly interfering with the hap. 


\section{WILD AND CULTIVATED FLOWERS}

piness of a gardener. Joseph has engaged in a war with insects which will keep him from idling the whole summer. No matter how persistently he labours, however, there is no surety that he will come off the victor. Bugs and worms have most horrid ways. They gnaw under the skin of young plants and greedily eat and stuff themselves with the sweet sap. Sometimes no one knows they are there until the leaves begin to turn yellow and gradually fall to the ground.

This yellow colour of the leaves of a plant dying from the effect of insects is to me one of the unsightly things in a garden. Perhaps I feel so about it because it indicates sickness. Every day I look over my rose-bushes for the little green crawlers that think they evade me by being just the colour of the leaves. That they might not find life too merry in the rosarium, Timothy sprayed the bushes very early in the season with a solution of whale-oil soap.

We welcome lady-bugs in our garden, since they go about eating many harmful mites. But between us we have only seen four lady-bugs this season, and, although Joseph may have them as well as the toads and garter-snakes for aides-de-camp, I hardly think they will be able to keep the insect army at bay. The spraying that Timothy gave them about the fifteenth of this month with a kerosene emulsion may prove the greatest hindrance to their advance. 


\section{WILD AND CULTIVATED FLOWERS $11 \%$}

Since coming to live at the Six Spruces, I have learned to face wasps and bees boldly. They do not, it seems, like people who are afraid of them, and wreak their anger by leaving a painful sting. This fact, Mr. Percy told us, was first taught by an American naturalist. Nevertheless, it took me some time to wear a smiling face in front of bees; and only because I was sure that Mr. Percy knew the truth, was I able to do it at all. But now I have quite ceased to fear them, and do not in the least mind their buzzing around me. Now I can, without screaming, let a bee or a wasp walk over my bare hand.

Yesterday at Nestly Heights we were standing by a large bed of azalea mollis. It was in full bloom, and surrounded by bees. I stooped to find the label of these shrubs, running my hand in under them and over the ground, until the telltale stick was found. I neither minded the buzzing bees, nor did they me, although I fancy they were somewhat disgusted that the flowers on my hat were without nectar. They soon learned their mistake, however, and forsook the artificial ones, my hands and shoulders as well, for the more hospitable golden funnels of the azalea.

Until this year Joseph and I had never seen azalea mollis. It is a Japanese azalea bearing astonishingly brilliant flowers. They are lemon yellow, bright, vivid scarlet, deep orange and every colour that can be seen in a soaring flame. At 


\section{WILD AND CULTIVATED FLOWERS}

Nestly Heights, many of these shrubs are set in a large bed near the gateway. Nothing, I think, could be more effective, now that they are several years old and have grown tall and stocky.

When autumn comes, the best time for transplanting azaleas, Joseph and I intend to buy a few to set out at the Six Spruces. In fact, Joseph has in his note-book that he will then buy azaleas, mountain-laurel and rhododendrons.

The mountain-laurel, the small laurel called lambkill and the wild azalea we shall probably set in or near the wood-border; but we shall use the rhododendrons as ornamental shrubs. $\mathrm{Mr}$. Percy tells us that we can get many of these plants from the woods and hillsides about here. They occur in hidden and out-of-the-way places, but not too far for us to drive to. The wild pink azalea is as lovely as any that grows, and no rhododendron, Mr. Percy thinks, could be more beautiful than our wild native one.

But the Japanese azalea mollis must have a place by itself at the Six Spruces, as it has at Nestly Heights. "Must we send to Japan for it," I asked Mr. Percy, "or to the nursery?" Then he laughed.

"Over our southern mountains," he said, "there is an azalea growing that is very like azalea mollis. The natives call it the flame azalea, although its botanical name is azalea lutea. A botanist named Bartram, who was searching the Appalachian mountains for rare flowers, first saw it when it was 
in full bloom, and said it appeared as if the mountain sides were on fire. "You and I cannot go to the south to get it," Mr. Percy continued; "its haunt is too far away; but I have often wondered that American nurserymen did not know more about this native beauty."

Joseph listened to Mr. Percy as if he were telling a fairy story. He later asked him many questions about the botanist Bartram. He said he knew that many great men had set out to find new land or the north pole, but that he had never heard before of their making explorations after rare flowers.

"Then, when we have time," Mr. Percy replied, "I shall have to tell you about a number that have done that very thing, even to risking their lives."

I was pleased for a double reason to think that some day we should have rhododendrons and laurels at the Six Spruces. I love their flowers and their glossy, evergreen leaves. As winter approaches, Joseph and I shall not leave Nestly, as do most of our neighbours. The Six Spruces is our home for all the year. Therefore, I tell him, we must pay attention to the plants that do not shed their leaves in the winter. Happily, the spruce trees are always green. If we could keep glossy, green leaves about us in the winter it would not seem so dreary. I do not mean that the country is dreary when there is snow on the ground, and glistening icicles hang from the boughs of trees. 


\section{WILD AND CULTIVATED FLOWERS}

Then the outside world is like Jack Frost's home. But days come in winter when there is no snow on the ground, or only sad little patches of it slowly melting, and then the bare earth and the dead leaves appear most melancholy. It is for such times that we must try to grow shrubs and plants that cling to their leaves. As well as I can remember, we have now only the six spruces and the hepaticas snuggling in the wood-border to look green throughout the year. There is, besides, the old pine near the point of the triangle, in which the grackles built their nest.

Still, it is difficult to plan for, or even to think of, winter in this month of May. Many of the plants that have not bloomed are getting ready to bloom. Although no buds may be in sight, one can tell their intention by their lively, important look. Joseph's seedlings have grown apace this month, and he is much interested in them. On my roses $I$ also see many small green buds.

The white dogwood blossoms in the wood-border have turned to brownish pink. They are dying. All over the country now, the leaves are fully unfolded, having lost the delicate, crinkled look they had in late April. We are no longer able to see the framework of the trees and the landscape in the distance. The foliage is growing dense, shutting out inquiring eyes. Still, the leaves have not been here long enough to become weather-worn or have their freshness soiled by dust. 


\section{WILD AND CULTIVATED FLOWERS 121}

Our Aunt Amanda's three lilacs have bloomed, shed their sweetness, and now are showing rust on their flowers. To me this is a distressing sight. I wish they would hurry and die completely. But I notice this rust also on the lilac blossoms at Miss Wiseman's and at Nestly Heights, so I have concluded that to turn rusty when dying must be their habit. 


\section{CHAPTER XVI}

THE LAST MAY DAYS

HERE is a time in the late afternoon, just when
it is passing into the twilight, that Joseph and I especially love to walk in the garden. Then it seems as if we could see things more clearly than in the sunshine. The fragrance of the garden at this time is also very sweet. We can look about sharply at the plants that we have tried to make grow, and wonder if they have done quite as well for us as they would have done in another garden. The failures do not always discourage us, because we will know better how to grapple with them another year. Apple blossoms and the pink dogwood of the wood-border have begun to drop their petals, and in many ways we are reminded that these are the last days of May.

In one thing we have been most fortunate. The season has been exceptionally fine for growing things. There has been too much humidity for the comfort of human beings; but this is something that particularly suits the plant world. Even the weeds have seized the opportunity to grow as never 


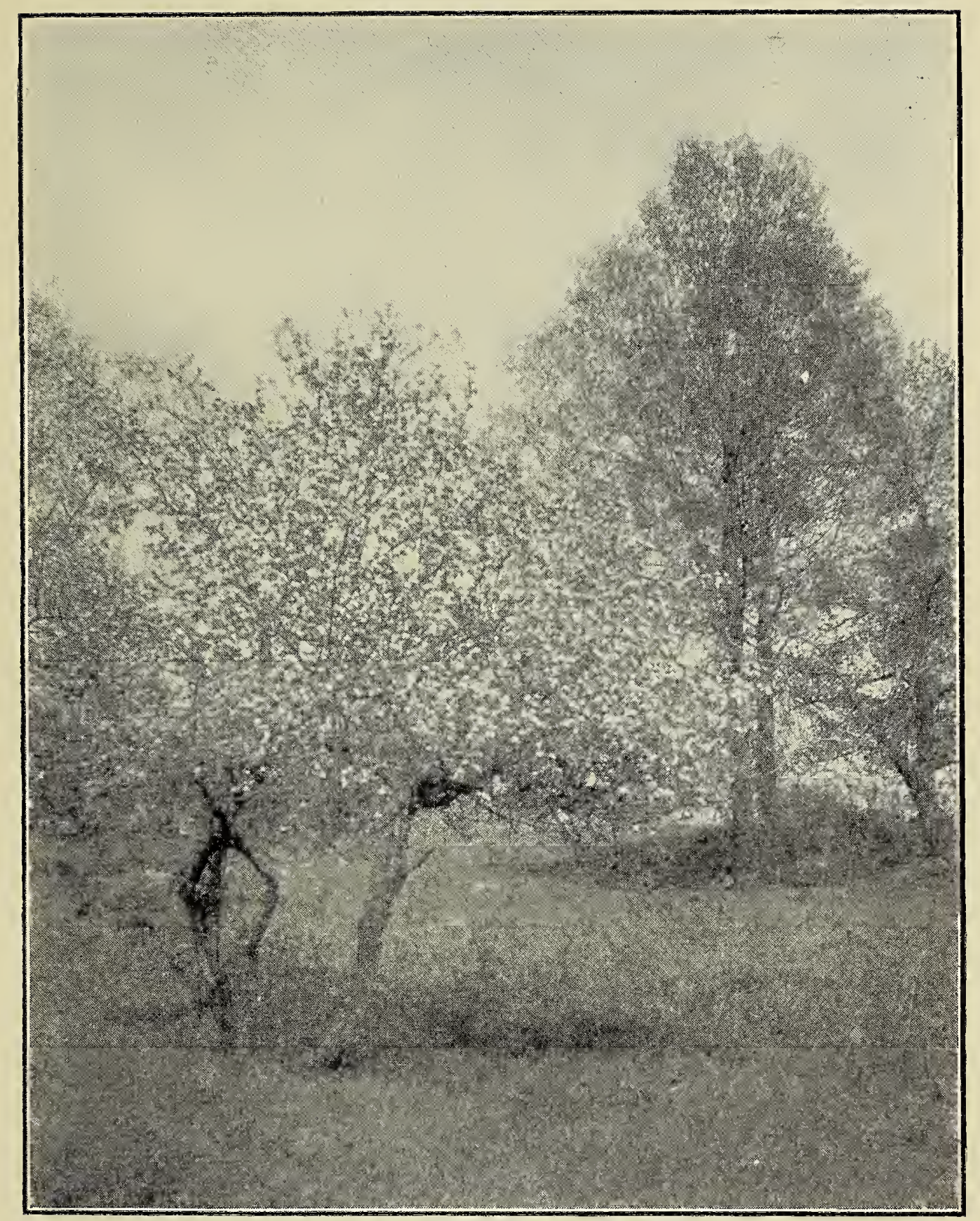

PLATE XXI.- "APPLE BLOSSOMS HAVE BEGUN TO DROP TIIEIR PETALS" 

before. Had we allowed them the privilege, the dandelions would have taken possession of the triangle, and now, should they catch us napping, they would come back in full force.

"Cut them down before they have gone to seed," Mr. Hayden tells us.

But who can know, Joseph asks, when a dandelion is going to seed? They are very quick in their movements, and make their balls of fluff-tipped seeds while one is thinking about getting a scythe. Joseph goes about, however, with a broad-bladed knife, and stoops and cuts them out of the turf as he passes along. He does this very much as the Italian women do who gather them in early spring. When we began to combat dandelions, I thought we had right on our side. Joseph and Timothy said they were weeds to be banished in spite of the backaches which I believe still visit Joseph, although he denies the imputation stoutly. I then for the first time began to take notice of these downtrodden plants. I saw they were truly beautiful, either in bloom or in fruit; and that they were more cheery and dainty than some of our garden flowers. Dandelions are roguish, besides, sticking their yellow heads up unexpectedly in the pathways. Still, authority says they are weeds, and correct gardening demands that we clear them away from the triangle, even if we had not another flower there to take their places.

Besides the dandelions, the tiny flowers of point- 
ed blue-eyed grass are now seen in abundance. At first I thought they faded and died on being picked, a habit different from that of quaker-ladies, which remain fresh in the house for a long time. Now, however, I have found out that while pointed blueeyed grass closes its petals with the first shock of being picked and placed in water, it is likely to open them again the next day at about noon.

At Miss Wiseman's and at Nestly Heights the dark crimson peonies are now in full bloom, while the double pink ones have colour showing about their buds. As yet the white ones about here have not opened. I wonder if Joseph and I are quite wise in choosing only white peonies for our autumn planting. The bursting pink ones at Miss Wiseman's are surely lovely. If they had fragrance one might almost imagine them a race of giant roses. Perhaps this autumn we can buy a few pink ones, as well as the white, and put them in the long, border-like bed somewhere behind the columbines.

Next autumn, next year! Joseph and I continually talk about these coming times. It seems as if we thought little of the things we have done so far, because we expect the plants to be so much larger and finer later on, and because there is always more planting in the wind.

Nevertheless, during these last days of May the triangle looks very pretty. The grass is kept so closely cropped by Timothy that it has lost its 


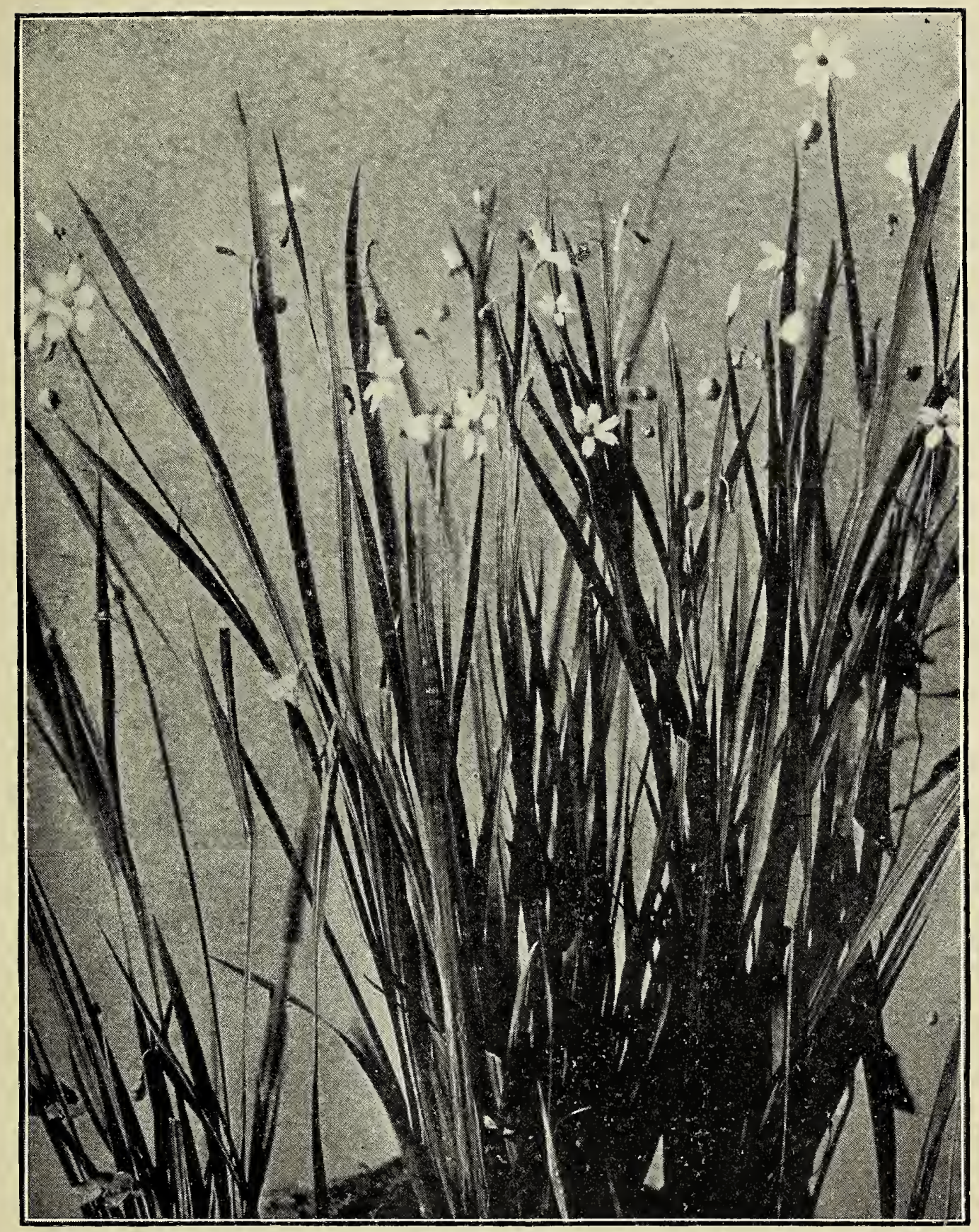

PLATE XXII.-POINTED BLUE-EYED GRASS 

coarse, ragged appearance, and begins to look like the velvet swaths at Nestly Heights. The columbines, the annual phlox, the irises, and the wild flowers of the wood-border, with the shrubs and the swelling rosebuds, keep us in a state of expectancy. Everything that we have planted has the notion of blooming well fixed in its head. The little quakerladies have, it is true, lost their blue blossoms, but their small leaves still cling like moss about the crescent bed. Mr. Percy was right in thinking that we could transplant them successfully.

So far, I have said very little about the moist point of the triangle, except that the grackles held carnival there; and that it was there we had planted the irises through the grass. This is one of the places from which we have great expectations.

The seeds of the cardinal-flowers that Joseph sowed early in the window-boxes, and which were so slow in showing themselves that we thought they were dead, have now this last of May been transplanted to this moist bit of ground. After they once started in the boxes, they grew well. Finally, Joseph had nearly fifty seedlings. He planted them wherever he chose in the point of the triangle, about six inches apart. It will be August before they can be expected to bloom, so we shall have another long spell of waiting for them. So far, I do not think their green stalks inspiring. They have a weedy look as they lift themselves up through the grass. Still, I must wait and see their flowers be- 
fore condemning their stalks. As Joseph says, in a garden there is always something for which one must wait.

We have planned to have quantities of forgetme-nots near the cardinal-flowers. In the wildflower world, these two always bloom at the same time, and seem to like being together, in moist, even swampy places. We are hoping that we have placed them where it will be wet enough for their taste.

For some time now we have had no rain, and our neighbours are beginning to talk about a drought. Should one really come, the work of gardening will be more arduous, since considerable watering will have to be done. We are fortunate in having in the moist corner by themselves most of the plants that love water. There Timothy can give the irises, the brakes, the cardinal seedlings and the forget-me-nots a good soaking, all at the same time. Not but what the other plants would all have to be watered, should a hard drought settle upon us, but they would not require it as often.

This is another thing that wild flowers seem to know how to manage better than those in a garden. They hold up their heads wonderfully in times either of drought or too much rain. No elves or sprites go through the woods and marshes with hose and watering cans, yet unmindful of adverse conditions, they bloom and bloom until they are ready to make their seeds. This and the fact that 
they are not so dependent on manure as garden flowers make me in a way partial to them. A little leaf-mould stirred in about their base is all they require while being transplanted.

Over at Nestly Heights, Joseph and I have noticed that no attention is paid to wild-flower gardening, and very little even to hardy garden flowers. The gardeners there like what they call bedding-out plants, interspersed with palms and ferns which have a sub-tropical air, and which have been kept over the winter in a glass house built especially for them. Early this spring Nestly Heights had a wonderful show of large, green plants and many intertwining beds of pansies and cyclamen. Some of the pansy beds were all yellow, others were all purple. Many of the cyclamen were solidly white, and again there were hundreds of clear magenta. These beds of cyclamen were nearly all bordered with a stiff-looking little plant, which reminded me of the old-fashioned hen-andchickens. Whenever a leaf turned yellow or one of the plants became sickly, it was taken out by a gardener and another was set in its place. The supply of them seemed to be inexhaustible. And truly they were planted in a way to give the grounds a royal appearance.

Gladioli, cannas and dahlias, so-called beddingout plants, are very popular and appear now in many gardens. This year Joseph and I have none of them. We hear that their roots have to be 
lifted in the autumn and taken care of over the winter. If we were not just beginning our garden at the Six Spruces, I should advise Joseph to have a few gladioli, for in August they are among the loveliest of garden flowers. In fact, it is a great disappointment to me not to have them. The cannas are very decorative, especially about a formal place like Nestly Heights. But it is their great leaves that I like to see waving with the breezes.

I have never especially liked dahlias, although Mr. Hayden and Miss Wiseman regard this as an instance of bad taste. Over their dahlias and the new varieties of gladioli they have more rivalry than about almost any other flowers. When Mr. Hayden urged us to plant dahlias, cannas and gladioli, I reminded him that the triangle was really a child's garden, with Little Joseph as its head gardener; and that, for this year, we wished to plant only hardy flowers which would grow freely.

He answered that, for a child's garden, my rose fan had quite a grown-up look. But then I begin to feel grown up, and have to be careful some days not to let Joseph know how much of a child he seems to me. Between thirteen and seventeen there is a very great difference. Joseph, however, is not at all like many boys. When he goes to school next winter, he will, perhaps, grow more like Ben and Harry.

Little Joseph is very thoughtful. Mrs. Keith 
says he is like our mother, and that it is because of her he can play the violin so well. Lately, however, he has sadly neglected his music. There has been so much to do in the garden that he has been tired when evening came, and scarcely able to keep his eyes open through dinner. Like all gardeners, he awakes early in the morning, and often has done considerable weeding before breakfast. The weeds sleep less than Joseph, and no place is sacred to them. If unwatched for a day or two, I believe they would grow up and choke our flowers.

When Timothy prepared the soil for the flowerbeds, making it light and rich, we little thought how well it would suit the weeds. It is a mystery where they come from. No seeds of them have been sown, yet they crop up more lustily than did the seeds in Joseph's window-boxes which he watered and urged so strongly to grow.

Timothy still believes, however, that weeds are the spice of a garden: that without them all else there would be tame and tasteless. Perhaps it is fiattering that our garden has the desire to be so highly spiced. In any case, I have found it necessary to buy a pair of rubber gloves that I may help Joseph with weeding. Mrs. Keith, who adheres to the ways of old England, where she was born, has bought me, besides, some frocks of blue-jean. They may be useful now that June is near, when I shall be struggling to become a' Rosarian. 


\section{CHAPTER XVII}

THE OPENING DAY FOR ROSES

O-DAY three roses are open. The calendar
shows us that June is here. Indeed, the summer has begun, with its heat, its sultriness, and its flowers. Behind us is the young month of May, and the time of our sowing and planting.

We fear somewhat that the dry weather will continue, and that dust and a dreary look will settle on the trees and flowers. Naturally, the drought will not be allowed to touch my rose fan, which happily can be supplied with water artificially. There, at least, I can defy any mischievousness of the season.

The three roses that are open in the fan to-day are Frau Karl Druschki, Clio, and Marshall P. Wilder. They are in advance of many others merely by a day, or even a few hours. The rosarium, indeed, shows a profusion of buds bursting and partly ready to show themselves as fullbloom flowers.

The Frau Karl Druschki is a rose such as I have never even dreamed of before. It is pure white, 
and very beautiful. I am to have many such roses, I can readily see, from the number of buds on the bushes. Even Mrs. Keith has now forgiven this rose for bearing its ugly name. She says it is the only one that has ever shared the place in her heart with the blush-roses of our Aunt Amanda. Joseph and $I$ are beginning to have a suspicion that it was Mrs. Keith, and not Aunt Amanda, who kept the blush-rose bush watered and fertilised from year to year.

The Clio rose that has opened is more rounded than the Frau Karl Druschki. From the number of buds I notice that these bushes also are: about to bear a profusion of roses. The catalogues describe them as very prolific, an expression which Little Joseph and I often use when speaking of a plant covered with buds or flowers. I like the colour of the Clio rose. It is faint pink, or pinkish flesh colour, becoming a trifle darker in the centre. Its outer petals are almost white. It will perhaps appear like a white rose among those of stronger pink, although by the side of the Druschki its whiteness is open to question. Happily, the Clios are all planted together at one of the tips of the fan, where they should be able to hold their own patch of colour.

The other rose in bloom to-day is Marshall P. Wilder. It is of a symmetrical, round shape and of a red so bright that I think sometimes it is carmine, or perhaps cherry red. What pleases me 
most about this rose is its fragrance. There never was such a sweet scent, I think, as that of a rose, and this one wafts it out most generously.

Joseph and I are beginning to know these three roses. But it is not only the bloom which one must regard and remember in order to become a Rosarian. There are, besides, stems and foliage to look at carefully. The main plan of the leaves and leaflets of roses is the same; but in their size, gloss, roughness or smoothness, and in their colour, they vary very much. Of the three roses that are open to-day, I think the Clio has the handsomest foliage; yet the rose itself is not nearly so beautiful as the Frau Karl Druschki, nor has it the charm of the Marshall P. Wilder.

Joseph and I have wondered why this rose was named after Mr. Wilder. Once, when I was quite small, I heard him declaim and tell some funny stories. But there is nothing funny or like Mr. Wilder about the Clio rose. It is not likely either that Frau Karl Druschki, should we ever see her, would remind us in the least of our marble-like, wonderful rose. It truly seems a shame not to give pretty names to roses. The Japanese call their chrysanthemums by such names as "MoonlitWave," "Ten - Thousand - Times - Sprinkled-withGold," and "The-Pink-of-Dawn." Mr. Percy would have called the Druschki rose "AwakenedSnow," but neither Joseph nor I quite understand the name. 


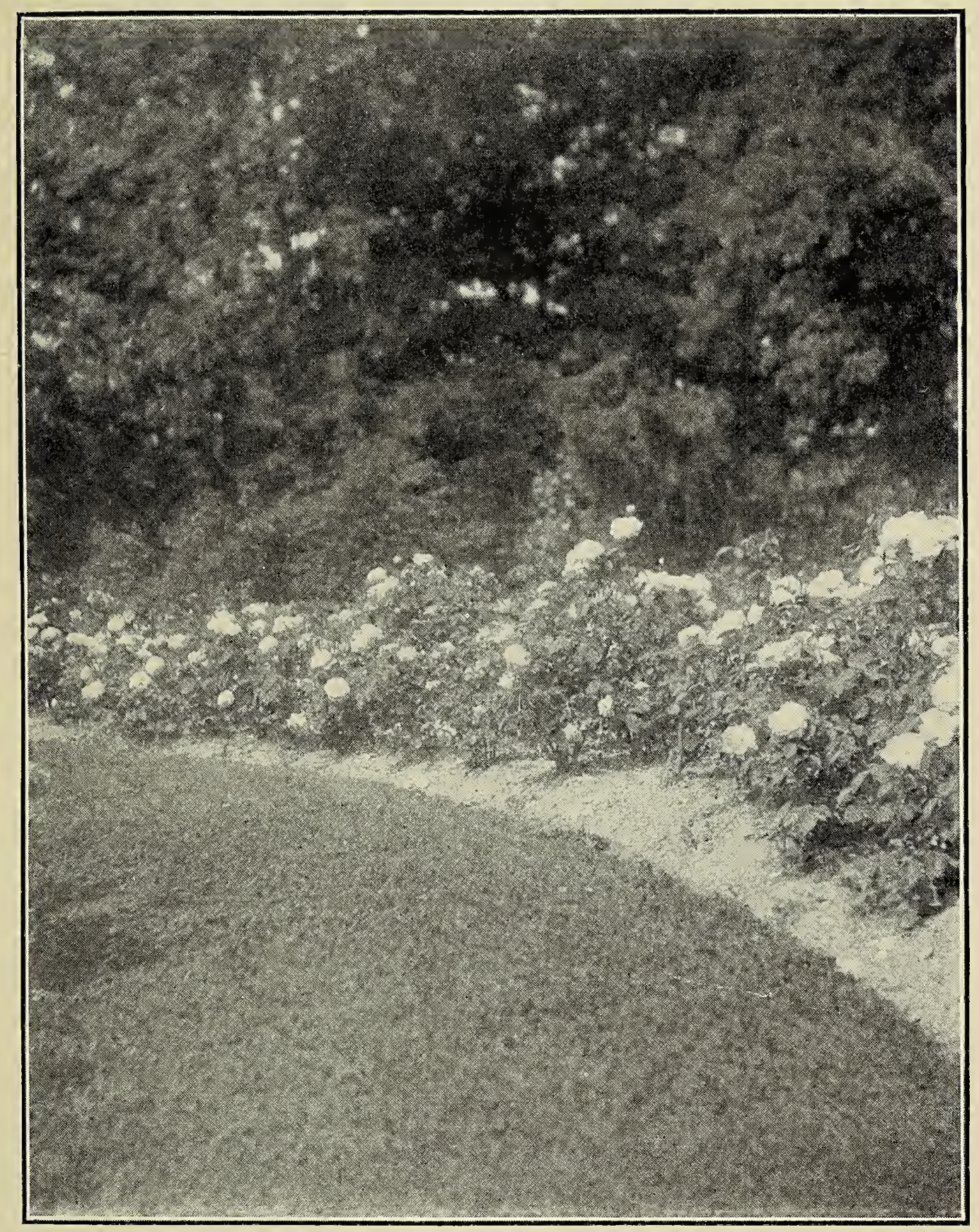

PLATE XXIII.-JUNE ROSES 

Yesterday Joseph spent part of the day at Nestly Heights with Ben and Harry. He played tennis and afterwards shot at a target. At the former, he was rather badly beaten, because he had not practised nearly as much as the other boys. At the target-shooting, on the contrary, he won almost every time. Now, Joseph is the kind of a boy who does not like to be beaten at anything. $\mathrm{He}$ therefore came home wondering if he could not have a tennis court at the Six Spruces. There is, he says, room enough for several; but it is the making of it this year that would be a nuisance.

Then it passed quickly through my mind that perhaps Joseph was beginning to lament he had not made a tennis court instead of a garden. Later in the day my doubts were set at rest by his saying that he had jotted the tennis court down in his note-book among the things to be thought of for next year. "The garden," he added, "is all we can possibly attend to now."

Sometimes I have thought it strange that more American children do not love gardening-that is, enough to plant gardens and to work in them every day. I do not mean merely to have the little beds for flowers that children call their own; but real, vital gardens after the fashion of those cared for by English children. It is true that a number of boys and girls in Nestly have gardens, but they all begin and end with the sowing of a few annual seeds. These children have told us themselves that 


\section{THE OPENING DAY FOR ROSES}

they do not know the difference between annual and perennial flowers.

Little Joseph's garden is one of which a man might be proud. It is his way to do things well when his interest is awakened. Miss Wiseman says he is a born gardener; and, as he is an owner of the Six Spruces, nothing could be wiser for him than to make the old place attractive. The fame of his work has begun to spread around the neighbourhood. Several people have asked if they might not come to see his garden. Naturally, this pleases him. He feels he cannot do too much work in it, nor keep it half tidy enough.

The oriental poppies which Joseph bought at the nursery are now making themselves seen about the triangle.

"Very much seen," Mr. Percy says, perhaps because they are so large, and so altogether different from our other flowers.

All of our oriental poppies have turned out to be as red as possible, although we have seen pink ones at Miss Wiseman's. Perhaps next season some of those that Joseph sowed in the seed-bed will bear paler blossoms. I am astonished whenever I look at these poppies, and cannot convince myself that I quite approve of them in our garden. They are too gorgeous for the triangle. Nestly Heights would suit them better.

I can fancy them in a fairy story, in which there are fields of ferns overhung by a green mist; where 
a fairy with butterfly's wings would dance and twirl her skirts about before stopping to rest under one of these great flowers. Such stalks and leaves would naturally appear very large to the little fairy, who probably would never see the serious black shadow in their centres, since the flowers would be upheld so high over her head. I can also picture these poppies reflected by electric lights in pools of deep water. I can think of them with oriental people, and see them often in dreams. I continue to marvel at their beauty, but I do regret their presence in the triangle.

Joseph fairly adores them. He is prouder of the oriental poppies than of any other flowers that so far have bloomed at the Six Spruces. Their bigness and their redness have made a great impression on him. He is pleased also that he planted them in the long, narrow bed in front of the wall, and at the back of the crescent bed. He believes his treatment of them to be quite modern, and that they give these beds much the same appearance as that of Miss Wiseman's hardy border. But, alas! Miss Wiseman has her oriental poppies behind pink peonies, which to me seems most strange. The only place I enjoy looking at them at all is in our own crescent bed, where they are near the green brakes, and near both the blue and the yellow irises. How fortunate it is, I have whispered to myself, that they are far away from my roses. It would be too bad to hurt Joseph's feelings by let- 


\section{THE OPENING DAY FOR ROSES}

ting him know that I am out of sympathy with his flaunting beauties. Besides, these ideas of mine about oriental poppies are, I am sure, not popular. Nearly all the places about here show them scattered among other hardy flowers. In "An Ambitious Boy's Garden," they are spoken of as "Great Wonders."

With May, the dogwood blossoms of the woodborder passed away, the wild columbines ceased to bloom, and the cultivated ones of the garden no longer put out new flowers. The German irises faded from our sight, and their places have been supplied by the Japanese, which indeed are exquisite. One clump of these irises is now showing yellow blooms.

Mignonette and nasturtiums are beginning to open in our garden. For both of them we have an especial fondness, since Joseph sowed the seeds out-of-doors in just the place where he wished them to come up, without having had first to plant them in the seed-bed. Of course, as these seedlings grew Joseph thinned them out, that they might not overcrowd each other. He spaced the mignonette about twelve inches by twelve, the dwarf nasturtiums twelve inches by ten, and the climbing nasturtiums that are lifting themselves up on the wall, about twelve inches by thirty. These plants are large and require more room in which to spread out than the other two.

June has also opened for us the blossoms of the 
spireas. They are large shrubs, having flourished several years under Miss Wiseman's care. Fortunately, the transplanting set them back but slightly. The name bridal-wreath, commonly given, is pretty for these shrubs, prettier far than the scientific one of spirea Van Houttei. It is, however, necessary to heed the scientific names of plants, since often many varieties of the same species are cultivated. Common and fanciful names, gardeners tell us, lead to confusion, while the use of scientific names saves one from misunderstanding.

Joseph and I, therefore, are trying to fasten the scientific names of some shrubs and plants in our memories, along with a number of the special expressions we hear used by our gardener friends. A few of these latter are "globular form," "gross feeder," "prolific bloomer," "very showy, and rapid grower." The last phrase, we notice, is an especial favourite.

While I am writing, more roses in the fan are opening. I shall go and sit on the rustic seat and try to see if they move slowly or quickly in unclasping their sepals and disclosing their soft, fresh petals. In the very heart of one there may be a worm. If so, I must seek him out and put him to destruction. Also there may be little green crawlers on the rose-leaves, which I must find some way of annihilating. Rose petals are much too sweet eating for worms, 


\section{CHAPTER XVIII}

THE COMEDY OF THE GARDEN

THERE is a strange, little comedy going on at 1 the Six Spruces. No bells have been rung announcing it; no cards inviting one to the play have been issued. Joseph and I, nevertheless, are its spectators. It is a comedy played by three actors, two chipping sparrows and a starling.

Long ago Joseph and I knew that a pair of chipping sparrows had built a nest in one of Aunt Amanda's yellow bell shrubs. It was a small, delicate-looking nest, lined very neatly with horsehair. Further than this we knew nothing, except that the female chippy sat on the nest in all patience, awaiting, we supposed, the time when tiny birds would peep their heads out from the eggs. Finally the young were hatched; for we saw the two chippies busy about the triangle searching for food.

What we did not know, however, was that starlings sometimes lay their eggs in other birds' nests; and that one had played this mean trick on the chippies. They, poor things, were brooding over and 
raising a strong young bird to which they were in no way related.

Now the starling, though still young, has grown larger than either Mother or Father Chippy. Their own children have had to learn to feed themselves, as the intruder's demands have been so loud and so persistent that the parent birds have had all they could do to satisfy the strange fledgling. Its appetite is enormous. From morning until evening it implores the chippies for food. Poor little things! they are at their wits' ends to account for its queer ways. Surely no young chippy was ever so stout and so emphatic as this bird.

The funny part of it all is that the starling appears to make the chippies do whatever it pleases. It hops about after them on the turf of the triangle, all the time calling to them, and reminding them of its appetite. Sometimes both of the chippies are feeding it at the same time. What can be their opinion, Joseph and I wonder, of this bold young bird that they have raised in their own nest? From day to day, they go on devoting themselves to the hearty creature, which before long will fly off in search of other starlings, forgetting forever its chippy foster-parents.

I think it is more a tragedy than a comedy. The chippies have a great burden on their shoulders which they were never meant to bear; and the starling, if it knew the truth, would surely be ashamed that its mother did not build her own nest, and 
hatch out her young. Even if she had wished to shirk her duty, Joseph says, she might have laid her egg in the nest of a larger bird than little Mother Chippy. For a bird of good size, the task of bringing up the starling might not have been so arduous.

Here now is Joseph wishing to tell me that the starling has just chased the two chippies behind the nasturtium vines of the wall, and is there scolding them very loudly. Perhaps they will be glad when it is old enough to fly away and leave them in peace.

As long as we lived in our old home, neither Joseph nor I had any idea how much and how often birds feed their young. We observed that, as soon as the robins had hatched their eggs, the male bird flew away from the nest, returning in from three to five minutes with a worm in his mouth. This he divided between four openmouthed, begging offspring. Then away again he flew, to return in about the same length of time, ready to do the feeding over again. So these birds kept on throughout the day. Joseph has watched them by the hour, and now believes with Professor Treadwell, who has gained his knowledge through experimenting with young robins in captivity, that each bird eats sixty-eight earthworms daily, or forty-one per cent. more than its own weight. If laid end to end, the Professor asserts, the length of these worms would be about fourteen feet.

The robin's nest is not a tidy little house, care- 
fully lined with horsehair, like the chipping sparrows. It is made of sticks plastered together with mud. How clever are the birds! The robins knew undoubtedly that they could get plenty of twigs and earth about here to construct their nest, while the chippies perhaps spied out our old horse, and noticed where the hairs had dropped from his tail.

So far, I have written nothing about one striking bit of beauty near the triangle. This is our morning-glory vine. Joseph sowed its seeds in May, although he had formerly crossed off all annual vines from his list; and since then we have been delighted with the rapidity of its growth. The flowers that are unfolding show us many colours from white to crimson, and then on to purple. The sight of morning-glories is not new to me, yet I have never before looked at them closely enough to see their full beauty. In shape they are quite perfect, and of a texture so fine as to be almost transparent. I am particularly pleased that we have these vines.

Yet on seeing them Miss Wiseman exclaimed: "Beware of those morning-glories."

Joseph and I wondered what she could mean. "They are weeds," Miss Wiseman explained. "Weeds?" Little Joseph and I said together. "They are indeed," Miss Wiseman continued, "and weeds of such determined growth that it is sometimes difficult to get rid of them. I have 


\section{THE COMEDY OF THE GARDEN}

known farmers who had a greater dread of morning-glories than of dandelions. They are vines that resow themselves, and if you fail to keep an eye on them they might even choke your rambler rose near by, or your clematis paniculata."

"But they are so beautiful," I said.

"Weeds!" Miss Wiseman replied, and I felt that for her the matter was ended.

Afterwards, Joseph and I put our heads together and decided that we would certainly keep our eyes open enough to prevent the morning-glories from choking anything at the Six Spruces; and that next year we would sow quantities of them in a vacant pasture back of the barn. There they may grow as much and as fast as they please. Nothing will be near enough for them to choke, except other weeds which are ugly. A field completely filled with morning-glory weeds would be, I think, most lovely. Indeed, those that we have this first season of our gardening have helped wonderfully to fill up the bare places.

I do not like bare earth showing in a garden. In most cases I think plants should be set closely enough together to hide it from view. Sometimes this is a wise arrangement, because they also hold moisture better than when the sun is allowed to play around them, touching and baking the soil at their base.

One garden in Nestly Joseph and I dislike especially. It is about the size of our triangle, 
although of a different shape. The greater part of it, however, has been laid out in flower-beds, intersected by paths of gravel. Not a spear of grass is to be seen. Now, wherever the planting has been insufficient-another term we have learned from our neighbours-only the bare hard earth is visible. In many places in this garden it appears that the planting has been insufficient. Joseph says he would sow morning-glory seeds, in spite of their being weeds, for this one season at least, rather than look at such unattractive beds of earth.

Whenever we see this garden, Joseph and I are pleased that we left the triangle in turf, making the beds only where they were needed. It would please me best to plant flowers through the grass, as Miss Wiseman had her snowdrops and other early spring flowers, and as we have done with the flowers at the point of the triangle. In some cases this is not a wise plan, because, after Timothy has cut the grass, which he must do frequently in summer, Joseph has to get down on his knees and use the sickle all around the base of the flowers. The free use of the lawn-mower is prevented by such planting, and, although the sickle cuts the grass well, it consumes a great deal of Joseph's time.

We are learning this year, however, that bare earth can be sufficiently hidden by having border plants about the beds, and the plants in them set closely enough together. In the rosarium, I should have liked the ground quite covered with ferns. 


\section{THE COMEDY OF THE GARDEN}

But ferns, alas! have very large roots, which would interfere with the nourishment of the roses. Besides, as I have written, these whimsical beauties thrive best when growing by themselves.

Many roses in the fan are now blooming. They are perfuming the air and the house as well, since each morning I have cut several with which to fill vases in the library. The form of the fan is said to be a success by our neighbours, who seem equally sure that the roses have done remarkably well. Naturally, I could not have had as large a rosarium this year if it had not been for the many strong plants which were given me by Mr. Hayden.

The ever-blooming or monthly roses which I bought at the nursery, and which form the semicircular base of the fan, are not opening with the lavish zest of the hardy perpetuals. Still, their period of bloom will continue from month to month, while those that are known as June roses will only give an incidental flower now and then after their great festival is over.

Among these so-called hardy perpetual roses, I notice especially the Soleil d'Or, or golden sun. Thus far, just one has opened. The outer petals are pale yellow, but the smaller, crinkled ones of the centre are a vivid yellow pink. It is like the sun saying "good-bye." The buds on this bush look small, and some of the foliage is wilted. I do hope it is not going to die. Mr. Hayden's gardener tells him that these roses are not the 


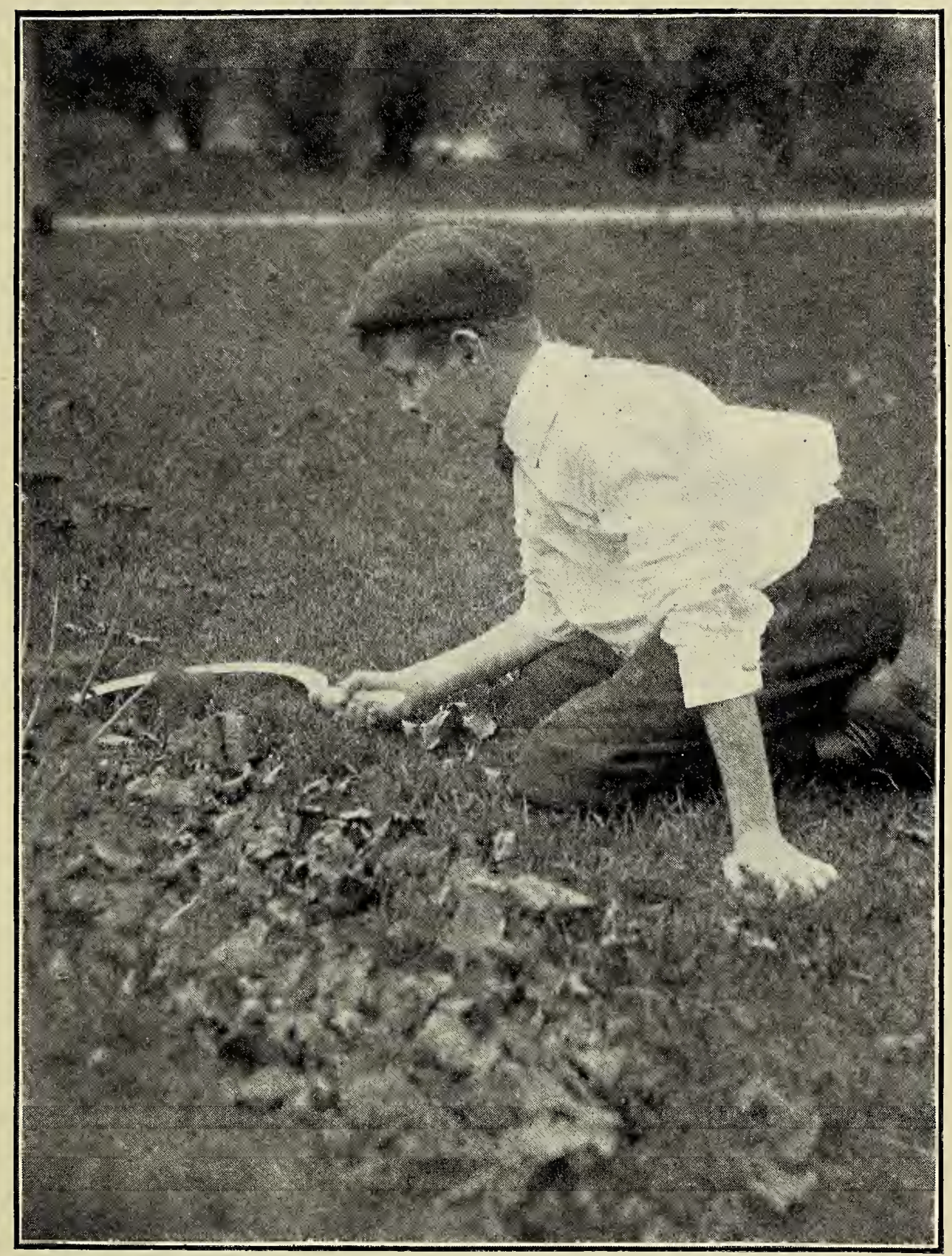

PLATE XXIV.- "JOSEPH HAD TO GET DOWN ON HIS KNEES AND USE THE SICKLE" 

easiest of all to grow successfully. So I suppose I shall pet and coax mine more than the others, and I may even give them a taste of something they like. As I told Joseph long ago, I feel sure I can make roses grow because I love them so much. It would be most grievous not to see the Soleil d'Or thriving. With the exception of the Maréchal Neil, I think it is the prettiest of all yellow roses. The Persian yellow ones at Miss Wiseman's are not a shade that is attractive to me; and I do not like their scent. I am glad we have none of them.

This year, May was such a warm and friendly month that few roses were frost-bitten or damaged. 'The gardeners, therefore, are saying that the little insect called the aphis has not had its usual chance to develop as a major pest. They seem to think that, when roses are perfectly healthy and vigorous, the aphis does not torment them so much, since it likes only the taste of sap that is tainted with disease. I am, therefore, making an effort to keep my roses well. Then, if the aphis comes in force, it will have to be dealt with in some radical, nowunknown-to-me manner.

Every girl or boy who has a garden will learn sooner or later to dread the aphis. It is a mite that, when only a day old, begins sticking its beak through the rind of plants and sucking their sap. Then gardeners resort to putting on destroying powders, syringing or sprinkling with tobacco- 


\section{THE COMEDY OF THE GARDEN}

water, only to find in the end that the aphis remains master of the situation.

"Remember," Miss Wiseman says, "that the aphis is a leech. It sucks bad blood. Prevent its coming by keeping your roses in good health." 


\section{CHAPTER XIX}

\section{A DAY OF PLAY}

$M^{R}$. PERCY is now home from college for the 1 long vacation. He comes very often to the Six Spruces, helping us in many ways about the garden. Yesterday he said that Joseph and I took our triangle much too seriously, and that we must cease working so hard that we forget how to play.

"After all," he said, "a garden is a place in which first to play and afterwards to work."

Joseph looked at him in amazement. I also thought something must be the matter with him. Could he, we wondered, have forgotten that the weeds were growing faster than I can write the fact down; that there were yellow leaves to be picked off; that our eyes had to be kept sharpened for insect pests; and that it was again time to sow the candytuft? Indeed, we felt that to-day $\mathrm{Mr}$. Percy was in a most frivolous mood.

"Those brakes we planted," he exclaimed, "I wonder if I could jump over their tops."

"I should like to play ball with those poppies," 
answered Joseph, turning suddenly playful himself.

Just then Queenie Perth appeared. She had her butterfly net with her, and, darting across the triangle, chased a painted beauty in and out among the roses. Mr. Percy, Joseph and I were after her in a second; for, if the butterfly had given her a chance, Queenie would have used her net, without thinking of the harm she might do to the roses. Joseph was the one who caught her, and dragged her out of the rose fan. She was as hard to catch as a humming-bird.

Queenie was annoyed at being captured herself before she had the butterfly.

"I will break the roses while you are asleep," she said to Joseph.

He smiled wisely, knowing well that the "sandman" calls for Queenie some time before he comes to the Six Spruces.

Happily, she next saw two tiny red butterflies, specked with black, playing tag with each other over the open turf of the triangle. At once she began to chase them, Joseph with her, using his hat as a net. These tiny butterflies, however, are clever. They continued their game so high in the air that she could not reach them, and, when they did swoop downward, it seemed as if it were only to tease her. Mr. Percy and I thought that both she and Joseph would make themselves dizzy twirl- 
ing about after these butterflies. Before long, they gave up the game and began chasing each other.

Mr. Percy and I walked about a little, and at length sat down on the seat overlooking the rose fan. When Mr. Percy is away, I think of much that I wish to say to him, of questions that I have to ask, and interesting things to relate; but, when he is here, they all seem to go very quickly out of my head. Although the roses were before us, each one blooming or showing swollen buds, I could remember nothing to say about them. I even forgot to ask why the Soleil d'Or rose, which I love so much, had always a few crinkled leaves in its centre, as if an insect had eaten it. I did not ask him why he supposed Joseph had wished to play ball with the great oriental poppies.

After a while he asked me if I ever felt lonely at the Six Spruces with only Little Joseph as a playfellow. I answered, "No, because I am always too busy to feel lonely." Then we sat still for a long time without saying a single word.

A little red squirrel came to the edge of the woodborder and nibbled at something he held in his paw. A robin hopped along in front of us with a fat fledgling by its side. Joseph fell down while chasing Queenie, and she promptly sat on him; the two chippies, pursued by the scolding starling, crossed the lawn while Mr. Percy and I sat watching. Almost anything might have happened without my thinking of a word to say. At length he took a 
note out of his pocket and gave it to me. It was from his mother, asking us there the coming Saturday afternoon to see the roses.

"But we have already seen them," I said. "We were looking at them only yesterday."

"Oh," Mr. Percy said, "that is only a way mother has of getting the people together. I believe it is to be a garden party, or something of the sort."

I said I would tell Joseph.

"You must surely come, though," Mr. Percy continued, adding that, if we remained away, he would think we would do less for him than for his father.

I cannot remember then how it slipped out, but I told Mr. Percy we thought his father very like the wind. I was sorry the instant I said it, and felt sure that Joseph would have known better. The words, however, were spoken; there was no calling them back.

I never heard Mr. Percy laugh so much before. Usually he is quiet, and a little grave. He seemed not in the least offended, however, that we had amused ourselves with this thought. When at length he stopped laughing, there seemed to be more things for each of us to talk about. He asked a great many questions about our lives before we came to the Six Spruces, and wished to know if we had found it hard leaving all our old friends, and coming where every one was strange to us. $\mathrm{He}$ 
was surprised that, at our old home, we had had no garden.

"Then I think you have done wonders here," he said. "Nestly Heights and Miss Wiseman will have to look out, or you will have the sanest garden of the three."

I did not quite understand then what he meant. As far as I know, all gardens are sane.

"Anyway," he continued, "you will have the most individual garden, because you are not led by gardeners to do a lot of unnatural things."

I thought Mr. Percy little knew the trick Timothy Pennell had of getting his own way in all that he did at the Six Spruces. Then, as I was beginning to tell him some of the many things that came tumbling into my head, we heard loud shrieks from Queenie Perth. We ran to the moist point of the triangle and found that, in her eagerness to catch a butterfly which had alighted on one of the irises, she had fallen into a soft, spongy place where her shoes had become covered with mud. During the night a slight rain had fallen and the place was wetter than usual. Joseph took tufts of grass and wiped off her shoes. In a few moments she was as happy and smiling as ever.

Her loud crying, however, had brought Mrs. Keith from the house. As Joseph and I saw her coming towards us, we knew something important was to happen, for on her head she had her best 
cap. It was one made of real lace and a velvet bow.

"I thought for once you four children were having a good play instead of worrying about weeds and flower-seeds," she said.

I hardly dared look at Mr. Percy. It seemed too bad for him to hear his father called the wind, and himself a child.

"You must come to the house now," Mrs. Keith said. "I will make Miss Queenie tidy in a minute, and there is something waiting for us all."

We hastened back then, hardly stopping to notice the pretty baby's breath on the way. $\mathrm{Mr}$. Percy sat Queenie on his shoulder, running with her across the triangle. Joseph crept up to me.

"Do you suppose," he asked, "that Mrs. Keith is going to give us something to eat?"

"Yes," I answered. The best cap could mean nothing else.

We found that she had set a table within the circle of the six spruces, that there were chairs around it, and that all we had to do was to sit down and wait for whatever was to be brought from the house. This turned out to be strawberry-shortcake, since June is the month for strawberries as well as roses.

Within the six spruces, where we were having our picnic, it was quite like a summer-house. The carpet was of fragrant needle-shaped leaves, and 
several large cones were lying about. Besides, it was cool and shady in there.

"This is a good way to keep you children out of the broiling sun," Mrs. Keith said, and again I hardly dared to look at Mr. Percy. "But," she continued, "as long as I was here with your Aunt Amanda, I never set foot within these six trees."

Joseph and I hoped she would do it soon again, and that she would call us for strawberry-shortcake every time. We never expect, however, to manage Mrs. Keith, although we sometimes try to persuade Timothy Pennell of our wisdom. Mrs. Keith, we know, has an idea of bringing us up to do credit to our great-aunt's memory. Usually; however, she is very kind and, now that the blushrose bush is in bloom, we have the courage to ask for anything.

Joseph was very merry at the picnic, and so was Mr. Percy. Queenie paid strict attention to the shortcake.

"There is not a flower in here," said Mrs. Keith, "nor a butterfly for you children to wonder about."

"There is a strawberry," said Queenie, before she had finished speaking.

"My children," Mrs. Keith said to Mr. Percy, and it was Joseph and me that she meant, "are working with the flowers all day and dreaming about them all night. Now, if I had my life to live over again, I would study the great trees." 
"They are flowers grown up," said Queenie, who had about finished her strawberries.

"You will never grow up to look like a tree," Mr. Percy told her. "You will always be a flower."

"I shall be a lady," said Queenie in a way that made us all laugh.

Before we had quite finished, Mr. Hayden burst into the summer-house. He had come up the long drive outlined by spruces, where the bridal-wreath is in bloom.

"I declare," he said, "it is an ill wind that blows nobody any good. Company drove me away from Nestly Heights, and here I stumble in on a party."

I had never seen Mr. Hayden more like the wind than at that moment. I wondered if $\mathrm{Mr}$. Percy also noticed it. The trees appeared to wave a little more, now that he had come.

He said that the shortcake was better than any he had had at Nestly Heights, which so pleased Mrs. Keith she cut him another slice.

"Been talking to my boy about roses or wallclimbers?" he asked me.

I told him, "Neither."

"Then it must have been about-about-well," he said, "I will tell you as soon as I finish eating this shortcake." 


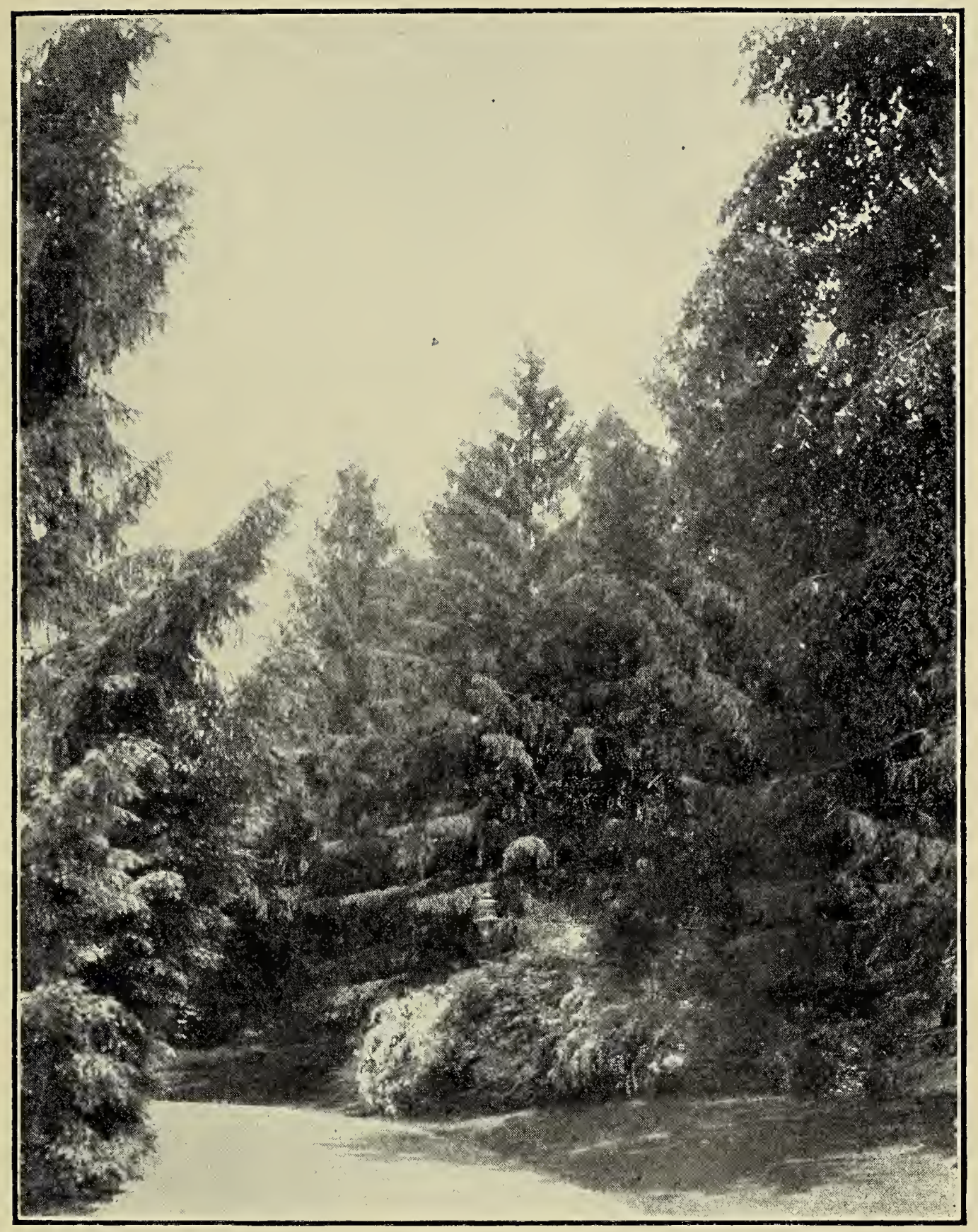

PLATE XXV.- "THE LONG DRIVE OUTLINED BY SPRUCES WHERE THE BRIDALWREATH IS IN BLOOM" 



\section{CHAPTER XX}

THE GARDEN GIVES ITS REWARD

$\triangle$ GOOD deal of the spring and early summer A work of sowing and transplanting that Joseph had attended to, is now beginning to reward him plenteously. Since the first of June, the sweet peas have been a delight to us both. They are blooming radiantly, showing large flowers, brilliant and sweet. Every day I pick enough to fill several large bowls for the library, besides having others to give away. It seems a little strange that we should have had such good fortune with these flowers. In planting them Joseph merely followed the directions of Miss Wiseman's gardener, and the seeds were also given him by her.

Yet Miss Wiseman says: "My sweet peas have not done well this year." And Mr. Hayden tells us: "The sweet peas at the Heights are hardly worth looking at this season."

No one seems to know the reason of their failure at these places, and all are astonished that Joseph's seeds have done so well. Mr. Hayden declares that, in a few years, no one will go to the Heights 
to look at his flowers at all, because those about the triangle will be so much finer. Joseph is very proud of having better sweet peas than any others in the neighbourhood, although his success must be only an accident.

Every morning, while the dew is still on them, he picks a large bunch to carry over to Miss Wiseman. Some mornings this bunch is all white; on other days, it is solidly pink, green, or perhaps purple. On the morning of the Fourth of July, which is now near, he will take three bunches, red, white and blue, tied into one. Miss Wiseman always invites a number of people to dine with her on that day, and she likes to have the national colours on the table. Timothy Pennell says he does not know of another plant that sends out flowers of these three, distinct colours with which to celebrate the Fourth. Perhaps I omitted to say that, in early June, Joseph again planted sweet peas along the side of the trellis, opposite to that on which he put them in March. We are thus hoping to have them with us for some time to come.

Joseph and I are glad we bought larkspurs (delphiniums) and planted them among the fernlike meadow-rues. They are now beginning to bloom, and the effect that we anticipated is being more than realised. As I have already related, we chose only blue larkspurs, which now; as they lift their star-shaped flowers above the surrounding green, remind me somewhat of the sea. This 


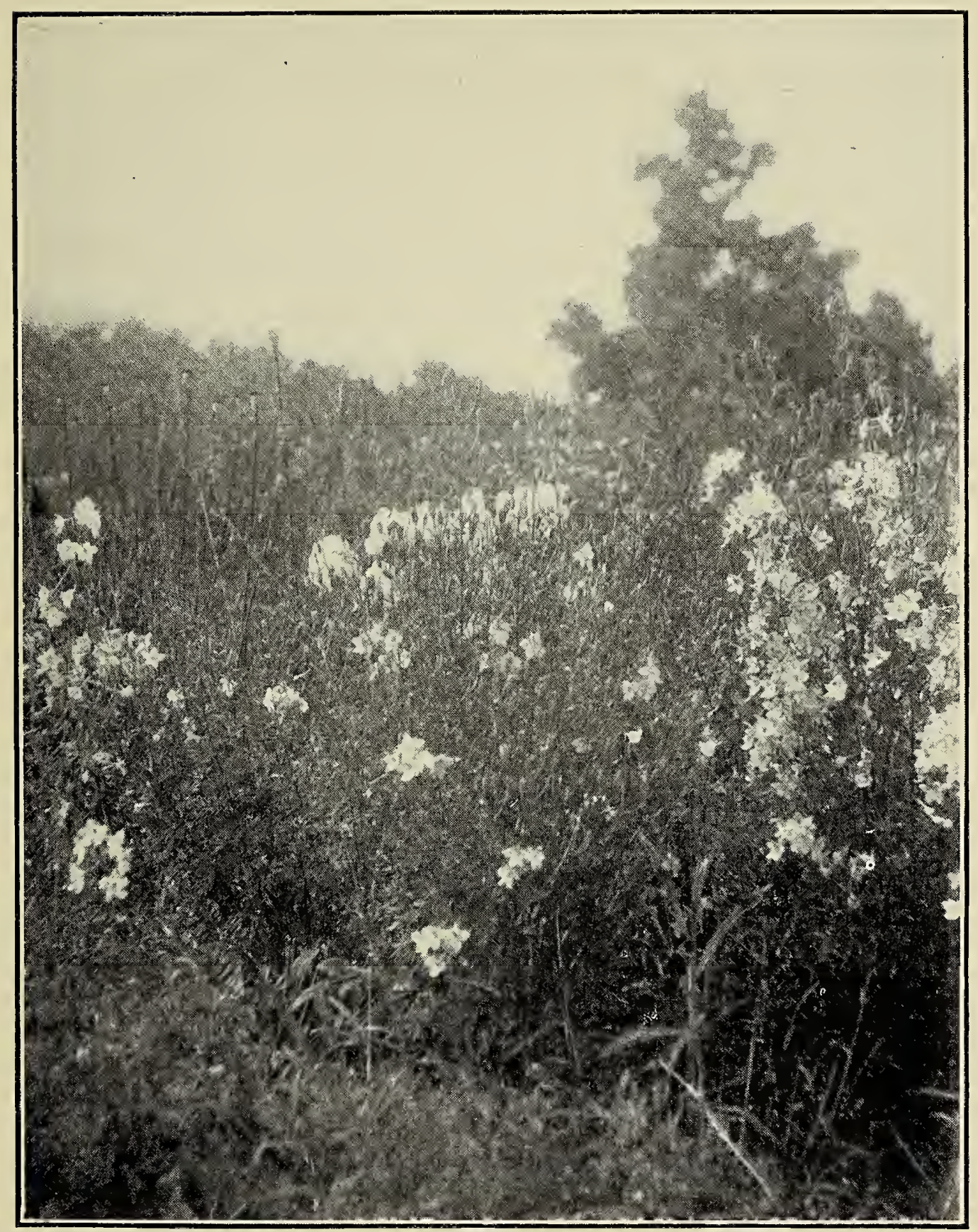

PLATE XXVI.— "WE LIKE TO OBSERVE THESE LARKSPURS" 

thought, however, Joseph cannot understand. $\mathrm{He}$ says that the sea, with its high waves and flying spray, seems to him very far away from our triangle. When he is in the garden with the ferns and flowers, I think he quite forgets that the earth has oceans and mountains.

Our larkspurs have shot up as high as three or four feet, and overlook the garden. All of the flowers of each stalk do not burst into bloom at the same time. Those at the tip-top open first, and then those lower down unfold. By the time the last ones are blooming, the ones that came out first have fallen, leaving their queer-shaped, upright seed-pods to tell where once they were.

We like to observe these larkspurs. I think I should know them now, no matter in what country I saw them or under what conditions. They have been given their names, we hear, on account of the way the flowers extend at the back into a long spur, like the hind claw or spur at the back of some larks' feet.

The only birds called larks that Joseph and I know anything about in this part of the country do not come into the garden-at least we have not seen them about the triangle. They stay in the meadows at a distance from the Six Spruces, and build their nests on the ground. They are called meadow-larks, although they are really not larks at all.

Joseph found out about their nests one day when 
he was crossing the meadow between Miss Wiseman's place and Nestly Heights. He was walking along without especially noticing anything, when suddenly, as if from under his foot, a meadowlark flew up in the air. He stooped at once to search for the nest, since he knew his passing had frightened the female bird and made her leave her home and eggs. Even so, it was several minutes before he located the nest; for it was sunken in the turf and then hidden by a clump of grass leaning over it like a roof. Five white eggs were within, flecked with reddish brown and purple. Joseph would never have seen the nest at all had not the bird told its whereabouts by her quick, upward flight. She could hardly help being frightened when Joseph's heavy shoe was so near covering her, and no doube her heart beat painfully.

Such larks as these are the only ones we know, so it was rather a disappointment to hear from $\mathrm{Mr}$. Percy that they were not larks after the true order. They are strong, fine birds, and we are now able to tell them readily from all others by their yellow breasts, marked strikingly with a black crescent. Joseph can even imitate their clear, sharp note. Mr. Percy says they are saying: "Spring o' the y-e-a-r, Spring o' the y-e-a-r." It seems odd he should have noticed this, for one day I read that these were exactly the words they sang.

Unless we wish to save the first crop of seed, Miss Wiseman says that, as soon as our larkspurs 
have borne flowers, we must cut down their stalks to the ground, so that others may come up and take their places. I feel sorry their present blooms must pass, but, as this happens with all flowers, it surely will be a wise thing to get rid of their stalks. The tall sticks bearing seed-pods are not a bit pretty. Joseph thinks he will cut down most of ours in order to have more flowers, but will leave others to mature seeds. These seeds he will gather, dry thoroughly, and afterwards sow in the seed-bed. From Miss Wiseman also he has heard that this is a better way to manage with larkspur seeds than to save them over the winter and sow them in the spring.

I seldom say anything to Joseph about seeds. He alone attends to such matters. At first, the idea of keeping plants from going to seed seemed strange to me, as I had thought that the very object of a plant's existence was to make seed. When they are allowed to do this early in the season, they regard their work as done, and therefore cease blooming; but when they are prevented from going to seed, they know it quite well, and so keep on trying to accomplish their object by sending out new flowers.

In every way must we be alive to take the best care of our larkspurs. They will live ten years in a garden, and every year send up stalks of more abundant flowers. As yet, no pest has attacked our plants. We notice, nevertheless, that Miss 
Wiseman has put ashes about the base of hers as a hindrance to a little white worm which, she says, delights in chewing their roots. This, of course, kills the plants.

Another strange thing in gardening is that a white worm, with a mouth too tiny for one to see, can cause the death of a beautiful larkspur four feet in height.

Not far from the larkspurs at Miss Wiseman's, there are lovely early lilies in bloom. I do not know that they have any English name other than lilies. Mr. Bradley invariably refers to the variety as lilium candidum, or candidums for short. I think he does this so that no one will make a mistake and imagine they are another kind of lily which he expects to bloom later. These beautiful fragrant candidums would be hardy in a garden like ours, and Joseph is almost as disappointed that we have none of them as he was about the early snowdrops and crocuses. Like these spring flowers, however, they come up from bulbs which it is best to plant in the autumn. Indeed, in his note-book, Joseph has already written about lily bulbs and when and how to plant them.

For myself, I prefer not to see them planted so near larkspurs and phloxes as they are at Miss Wiseman's. They have an expression so different that I think they should be kept by themselves in some green nook. This thought, however, I 


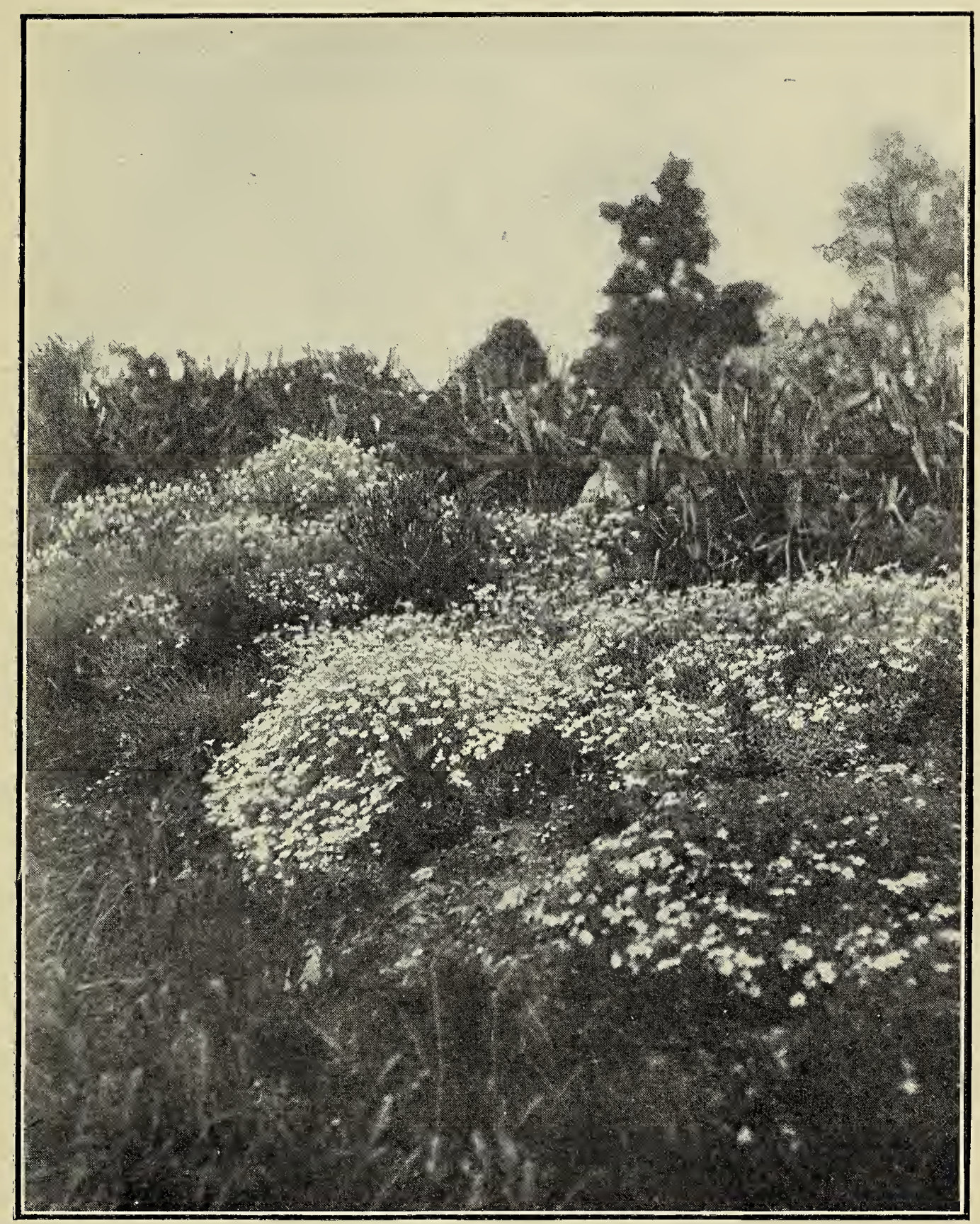

PLATE XXVII.-PHLOX DRUMMONDI 

am reserving until the day that Joseph starts out to plant lily bulbs about the triangle.

As I look at the ferns and brakes at the moist point of the garden, it seems as if the world was quite different, when we took them from the woods, from what it is now, when so many plants are unfolded. Then it was spring. Now that summer is here, we remember those spring days, feeling that we did not half know their loveliness. There was something sweet in watching the tender twigs growing. But bursting buds and the unfolding flowers were the best of all. Now, almost everything is well grown. Even our wood-border has a dense look with its large, solidly green leaves. 'The little spring flowers that bloomed so peacefully there have been pushed quite out of sight by the larger, bolder plants that came with summer.

We have had little rain, and the dust has so covered the trees as to take away their freshness. As yet, this dusty look has not touched our garden. Joseph and Timothy have been faithful in keeping things well watered.

The sweet alyssum, candytuft, mignonette and the phlox Drummondi have been saved from going to seed by having their flowers nipped off as soon as they began to fade. In consequence, they are all still blooming cheerfully. Of course, this requires a great deal of work. It is, however, work that both Joseph and I like. We do it towards twilight, when the sun has ceased sending upon 


\section{GARDEN GIVES ITS REWARD}

us its burning rays. Sometimes Mr. Percy comes and helps us; but we never allow Timothy Pennell to spend his time over anything so simple.

Mr. Hayden has taken both Ben and Harry away to the mountains. At Nestly Heights there are now left only Mr. Percy and his mother. We have missed the visits of Mr. Hayden very much, as he always has surprises and secrets up his sleeves for us. Joseph hopes he will soon come back, bringing a strong northeast wind with him from the mountains, for we are sadly in need of rain. But I have always noticed that Mr. Hayden talks about our Aunt Amanda whenever he is in one of his northeast moods.

Before Ben and Harry left for the mountains, Joseph grew fond of them. He found that, although they neither understand nor love flowers, they are extremely wise about catching fish. They know every good stream near Nestly, the names of the different fish, and the kind of bait each prefers. Little Joseph frequently left the garden to go with them, and every time he returned he seemed to think them finer boys than before. They now stand very high in his esteem. 


\section{CHAPTER XXI}

THE DROUGHT

FVER since Joseph and I began our garden, we C have thought of the sun and the clouds as our helpers. But now we no longer know what to believe about them, since suddenly they have turned most unfriendly. The July sun, instead of merely warming the soil and coaxing the plants to grow, has become a fiery enemy. Its touch scorches and burns. The clouds no longer send kind rains, but pass and repass each other on a sky so clearly blue that it looks as if they had forgotten the needs of the earth.

"The drought has begun," Timothy Pennell told us.

"The drought is upon us," say the gardeners at Nestly Heights and at Miss Wiseman's; while Joseph and I gaze at each other and wonder what we are to do. A sadly withered look is to be noticed about many of our vines and plants: even the shrubs are showing their need of a good, long drink of rain-water.

Of course, every evening at twilight Joseph or I63 
Timothy plays the hose on the near-by spots of the triangle, and takes buckets of water on a wheelbarrow to the beds farther away. Otherwise, many of our plants must already have died. It is even necessary to water the grass, to keep the little blades from turning yellow.

I have been especially careful to keep the roses well watered, even though many of them have passed the height of their bloom. The Clios are still showing great profusion of flowers. They seem determined to have more of their blossoms in the fan than any offered by their neighbours. These Clio roses, as I mentioned before, were a very delicate pink when they first opened. Now, however, they have faded almost to white. Joseph thinks that this has been done by the fiery sun; but $\mathrm{Mr}$. Percy, who I am sure knows best, says it is the habit of Clio roses to become pale as they grow old. I had never before thought of a rose growing old. I had noticed their fading and dying, but it seems strange to think that they do so because they are growing old. Roses always seem young to me, while pansies, I think, have an old look.

I am almost sorry I planted so many Clio roses near those of deeper hue. Another year I shall put them in a bed by themselves, away from the fan. Now, when looking over the rosarium, it is difficult not to give them too much attention, and to notice too little the more beautiful monthly roses. 
Joseph's crimson ramblers along the wall are blooming. They have not grown very high this first year, although we are pleased to see them well covered with buds. We have kept them watered that they might not feel the drought; nevertheless, I cannot help thinking that they know all about it. Plants are not easily fooled. They have a look which plainly says: "You can water us as much as you like, but you cannot make us forget this severe drought."

We wonder how long the drought is going to last, and wake each morning only to see the sky more intensely blue than it was the day before, and to find the sun more burning. Joseph says that such a thing as a drought was never mentioned in "An Ambitious Boy's Garden," yet surely no one could have a garden many seasons without having to contend with one. In this part of the country, Mr. Hayden says, a drought comes almost as regularly as the aphis. It is one of the things that gardeners have to endure with patience. After all, I tell Joseph, it is much better than if we had had a flood washing all the plants away. If the clouds sent us too much rain, we should be quite helpless; while we can combat a drought by artificial watering. Still, it is no end of a nuisance. The most discouraging part of it all is to hear our neighbours say that the drought has just begun. "If it would only end to-morrow!" Joseph and I exclaim each evening. Then on the morrow we rove about, 
noticing where and what we shall have to water in the twilight.

When watering our plants, we have learned not to give them just a little sprinkling and then to move on to the next. Instead, we have divided our garden into three sections, which we water in turn, giving each a thorough soaking. We try to have the water get way down into the earth, about the plants' roots, as it is then likely to keep them moist for some hours. A light sprinkling, such as Queenie Perth gives her flowers, does them hardly any good. It dries quickly, and helps the sun to bake the soil harder about the roots.

A new garden feels the drought more than an old one like Miss Wiseman's. There the shrubs and plants which have been growing for years form such thick masses of growth that they hold the moisture much longer than a garden where plants are fewer and not so well grown. Almost every day Miss Wiseman comes to the Six Spruces and says: "Now, children, don't be discouraged about this drought. Keep your plants alive this year, and next season they themselves will be able to help you."

I like the thought that, later on, the plants will help us; because, now while they are young and scarcely at home in the garden, we are caring for them. It gives one a feeling of intimacy with the flowers, as though they understood one a little.

Some of our plants have borne but few flowers 
this year. Still, these few have told us that the plants had taken root, and that they are content with us. Sometimes we are almost as happy over a few flowers as if we had a hundred, feeling convinced that, as the plants grow old, they will bloom more abundantly.

Joseph and I have the same desire about the Six Spruces that Mr. Hayden has about Nestly Heights. 'This is the wish to have it appear as beautiful as possible, or, as Mr. Hayden says, to have it give a good account of itself.

Besides watering the garden these dry days, Joseph and I are busy keeping the soil about our plants well stirred and loose. Usually, Joseph rakes about them, but, in places where he cannot reach easily, I take the trowel or a little pick, and stir up the earth very lightly, being careful not to go down deep enough to touch any of the roots. This loose earth acts as a mulch and keeps them from feeling the drought as much as they otherwise would.

Lately I have almost lived in my blue-jean frocks, there having been so much to do in the garden. Sometimes it is very hot. The sun pours down and its heat burns me as much almost as if I were a plant. I can run into the house, though, or to the shade of the wood-border when I am weary, while the poor plants must always stay in their places. Joseph is like a sunflower. The heat 
seems to disturb him very little, but every day he turns a trifle browner.

We can never be too glad that we have the woodborder on one side of our garden, and that the point of the triangle is naturally moist. Although ferns and irises feel the drought more than many other plants ours are still holding themselves up and looking well. Unless we have rain soon, however, we must water them more freely. This will be somewhat awkward, as they are in the part of the garden to which water has to be carried in buckets.

Aunt Amanda had but one hydrant at the back of the house, and the hose from it will not reach all over the garden. In the future, Joseph and I plan to put in another hydrant farther down the triangle, to do away with the labour of carrying water. Just when this "future" will be I do not know, but I hope before another season when there is a long drought.

Joseph's ten-weeks stocks have bloomed early. They come from the seeds that he started in one of the window-boxes early in March, and now, in the long bed by the wall, are showing us masses of pink, purple, yellow and white. We do not know how they like the drought. We try simply not to mention it in their presence.

It means a good deal of work to sow annual seeds each year, to watch that they grow well, thin them cut, sometimes transplant them, and generally look after their comfort until they bloom. But, when 
all is done, they send out their flowers abundantly, as well in a new garden as in one centuries old. Our stocks, Joseph says, are quite as fine as Miss Wiseman's, and much better grown than the few at Nestly Heights. For this reason I like annuals. Those that we have planted this year have bloomed as well as they ever will, because it is the only year that they will bloom at all. The first frost will kill them.

Our perennials have also done well, we are told; but they have always made us remember that this is their first season, and that we must not expect to find out how gloriously they really can bloom until next year, or even the year after.

Every season we will plant ten-weeks stocks. This much is decided. I like the soft, pretty colours of their flowers, and the way they hold their stalks erect. At twilight, when we are working about them, they send out a fragrance more noticeable than under the burning sun. It seems as if they wished to let us know their gratitude for giving them drink in this dry weather.

It must have been in a moment of inspiration that Joseph planted these stocks where he did, because, if they had been put along the border, as he first planned, they would have grown up and hidden the plants behind them. Fortunately, he set them well back in the bed, three rows of them, which sometimes break the straight line and form clumps. It was no doubt accidental that they came 
up in just this way. The effect, nevertheless, is lovely. We have so many of them that I have picked them to give away and to make bouquets for the house.

I am also giving away a great many nasturtiums. These vines have grown and bloomed splendidly. Joseph and I count them also among the annuals that we will have each year as long as we have a garden. I love the soft green of their leaves and the many gay colours of their flowers. Every time I look at them, I see combinations of red and yellow which I had never before noticed.

As Mrs. Keith anticipated, she sometimes picks the leaves of the dwarf nasturtiums and prepares them as a salad, or else mixes them with other greens. In fact, eating these fresh salads from our flower garden makes us wonder if we would not like to have a vegetable garden at the Six Spruces.

Most children, Mrs. Keith tells us, would have thought about planting peas and corn before they troubled themselves about flowers. 


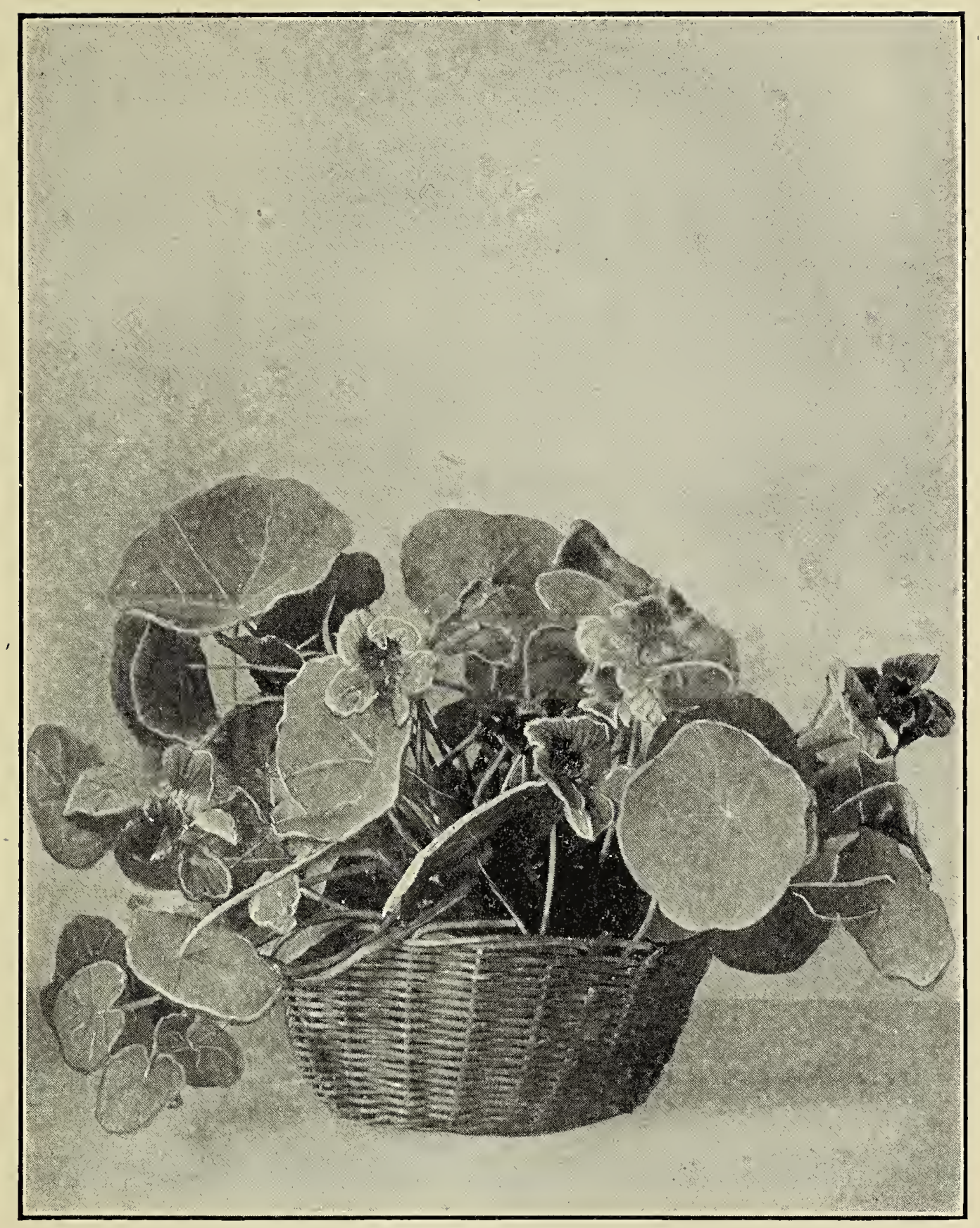

PLATE XXVIII.-NASTURTIUMS 



\section{CHAPTER XXII}

\section{OUR PHLOXES AND HELIOTROPE}

T still seems curious to me that Little Joseph is 1 the only boy in Nestly who owns a large garden and who really loves to work in it. I notice that there is room for gardens about the homes of most other boys, even though some of them might have to be small. Boys, I think, do not know the real pleasure there is in gardening, nor the many delightful things they might learn about Nature when working so close to the soil. Of course, it is right for boys to play ball and tennis, and to enjoy themselves in the open. Still, they cannot do these things every hour of the long summer. In the time they waste they might almost make and tend a small garden. It is true that few boys of Joseph's age have as large a place as the Six Spruces to roam over; but, even so, I do not think they take advantage of the ground they have at hand.

Girls also are very slow at making gardens, and this astonishes me more than the lack of interest among boys. Indeed, Queenie Perth and I are the only ones in Nestly who work in our own gardens. 


\section{OUR PHLOXES AND HELIOTROPE}

Queenie's garden is very different from my rosarium. It is merely a small patch of ground on which her aunt allows her to sow seeds, and this Queenie declares she does so the butterflies will come and stay near her. Nevertheless, her little garden is pretty, although, should I relate all the colours she has there crowded together, it would sound like a description of Joseph's coat. I do not, of course, mean any coat belonging to Little Joseph.

Queenie thought nothing of stealing the wren's egg and then breaking it. Yet she will never pick one of the flowers that grow in her own garden. She says it hurts them. We have both noticed that, as soon as Queenie begins to understand about a flower, to sow its seeds, and water and care for it herself, she begins to love it very dearly, almost as well, in fact, as she does the butterflies. To the flowers in her aunt's garden, or to those on our triangle, she pays small attention, appearing even not to see them. This, I think, is because they are not her own, and have given her no trouble.

She told Little Joseph that she loved the sweetwilliams in her garden best of all, because one day she saw three yellow butterflies visiting them at the same time. She never misses seeing a pretty butterfly, and I have also watched her playing with large, bright-coloured beetles in her hand.

Our phloxes made Queenie open her eyes when she came last to see us. She called them flower butterflies, and I agreed with her that these plants, 


\section{OUR PHLOXES AND HELIOTROPE 173}

which now are blooming in several places about the triangle, have done more to cheer up the Six Spruces than any others we have had. When Joseph planted them, I had no idea how beautiful their colours would look in bold masses. Besides, the clusters of flowers are large and very brilliant. Mr. Percy is likewise enchanted with our phloxes. He tells us that we can keep them in flower until nearly the time of frost, by clipping off their heads after they have passed their first bloom. At present, it makes me shudder to think of clipping them.

Although these phloxes grow very tall, they do not require to be held up by stakes. This is another of their good points. So far, I have never seen mere stalks that were things of beauty in a garden. Those of the phloxes have a way of standing up erect by themselves, and, although I still think them plain and prim, all is overlooked now that they are so gloriously crowned with blossoms.

While I wonder why more girls and boys in this country do not have gardens, as is general with the children in England, it would cause me greater astonishment to hear of a child's garden without phloxes. We have found them very simple to grow, and from now on they will increase, so that at the end of three seasons, when we shall have to divide their roots, we shall likely have three times as many to set out as are now in the garden. Then $\mathrm{Mr}$. Hayden would at least be right in saying that, 


\section{OUR PHLOXES AND HELIOTROPE}

if our Aunt Amanda returned, she would not know the Six Spruces for her old home.

Although Joseph and I watch the garden closely, there are sometimes things going on there that we know nothing about. This morning, while I was picking off a few dead leaves in the rose fan, I spied a chippy bird's nest closely tucked in one of the bushes. It was quite empty. In fact, this nest had been made, the eggs laid, and the young fed and taught to $\mathrm{Aly}$, all without our knowledge. We do not remember even to have seen the chippies about the rosarium. I do not mean that there have not been many chipping sparrows at the Six Spruces. They are as numerous here as robins. But we have noticed none that awaked our suspicions concerning the nest in the rosarium.

These birds must have managed their building and housekeeping very cleverly. Every day I have been among the roses, but no mother bird flew out in wild alarm, nor did I hear her mate calling to her. Perhaps they were wise enough to know that Joseph and I would do them no harm, and therefore they made no sign at our coming and going. They must have brought the horsehair, with which the nest was lined, from near our barn; yet Joseph did not notice them about there. $\mathrm{He}$ is astonished that a whole family has been raised on the triangle without his knowledge. We cannot imagine what will happen next.

Sometimes we wonder what goes on in our gar- 


\section{OUR PHLOXES AND HELIOTROPE 175}

den at night when the stars are keeping watch. We know that moths come out then which are not here in the day; and perhaps some little animal comes to the edge of the wood-border, and looks at our flowers with his bright eyes. In the mornings we find our garden glistening with dew which no one sees forming; and twice in the soft earth I have noticed footprints that were unknown to me.

The most dreadful thing in the world to hear at night is a screech-owl, to be awakened by its moaning, piercing cries, and to be obliged to listen to it until near dawn. Lately Mr. Percy told us that, although these birds make such a melancholy noise at night, they should be welcome because they eat mice and help to keep the heliotrope from being devoured by cutworms.

These hateful cutworms come out at night. In the daytime, like screech-owls, they hide themselves away. It would be hopeless, therefore, for Joseph and me to try to pick them from the heliotrope leaves which suit their appetites so well. The screech-owl knows their ways, and in the night, when they are having a good feast, this sharp-eyed bird catches and eats them, and all to the benefit of our heliotrope.

I wonder if I have written before about the heliotrope-bed. It is one of the smaller beds of the triangle in which, in May, we set three dozen plants bought from the nursery. We kept their buds nipped off until they were well rooted, and since 


\section{OUR PHLOXES AND HELIOTROPE}

then the bed has been a mass of deliciously scented flowers. The border plant used for this bed was sweet alyssum, which, since Joseph has sown it in succession, has kept constantly in bloom. Nearly every one that comes to the Six Spruces admires this bed of flowers. At Miss Wiseman's and at Nestly Heights, there is no especial place devoted to heliotrope, a few of them being merely set in here and there among other plants. No one, therefore, can get the great wafts of fragrance from them that we do from our flowers, nor do they appear so conspicuously beautiful. Sadly enough, this heliotrope-bed has been rather an extravagance for Joseph and me. We had to buy the plants, and they will endure but for this one season. As soon as frost comes we must bid them good-bye.

Mrs. Keith knows an excellent way of keeping heliotrope fresh in the house. Before we pick it we carry to the bed a small pail of hot water, in which the stems are plunged as soon as they are cut. Later, the flowers are arranged in the house, where I fill the bowls and vases with the same water. By treating heliotrope in this way we have had it remain fresh four and five days.

This morning, when Timothy came to cut the lawns and trim around the flower-beds, he said that he felt rain would be along in about twenty-four hours. Mrs. Keith did not agree with him; so now Joseph and $I$ are waiting to find out which of them is right in the matter. We hope it will be 


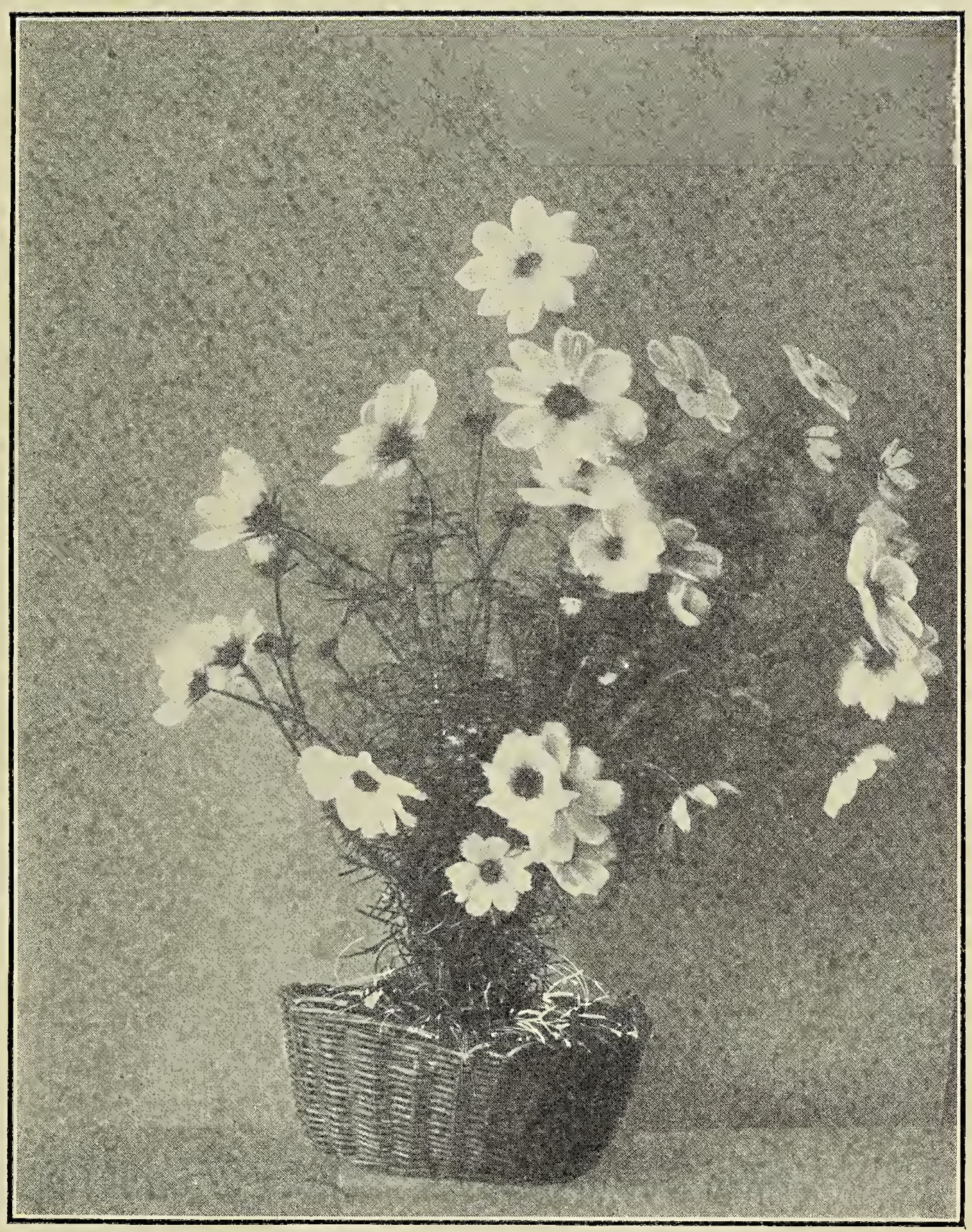

PLATE XXIX.-COSMOS 

Timothy. 'To us the sky still looks very blue, while the sun is bright and intense.

The spruces and evergreens are feeling this heat. They have now a dark, rusty look, while the enchanting spring growth, which so enlivened them, has turned the same colour as the rest of the trees. It is only by looking sharply that we can tell how much each spray has grown this year. However, we think little of evergreens in mid-summer. Only when winter comes, and they are still green, do we turn to them in gratitude.

The cosmos that Joseph sowed in the seed-bed the very last of April, and transplanted later to the long bed in front of the wall, is now blooming quite lustily. The colours of the flowers are pink or white. In staking these plants Joseph exercised his ingenuity, hiding the supports so skilfully among the stalks of feathery foliage that they are seen but little.

It is amazing to me that these plants should have grown so high in such a short time. Many of them are taller than I. If we are to keep them with us until frost we must prevent them from making seeds. I like these cosmos flowers. They have a clean, cheerful look, something like the daisies that bloom in the field.

I once thought that flowers had nothing to attend to in life, but I now find that they have a great deal with which to concern themselves. First of all, they have to adapt themselves to the soil where 


\section{OUR PHLOXES AND HELIOTROPE}

people plant them. And to have the right kind of soil for flowers is something that few boys or girls think enough about. They have to grow, even when the clouds are unkind and send no rain. They have to heal up many wounds which are made by gnawing insects; and they have to open their flowers. There are also seeds to ripen, that they may be scattered over the ground. But in our garden, plants must be very sharp to get ahead of Little Joseph when he wishes to interrupt this good intention.

I often feel sorry for them. Surely, they must be discouraged when flower after flower is cut off and no seed has been made. They cannot know that Joseph is luring them on to bloom until Jack Frost steps into the garden. 


\section{CHAPTER XXIII}

\section{THE END OF THE DROUGHT}

AST night the rain came. This morning it is L falling in torrents. If it continues long it may overwhelm everything in the garden. Joseph and I can only stand by the window and watch as it descends violently on our flowers. Besides being drenched, the cosmos are being tossed about until Joseph wonders if their stakes will hold firmly in the ground; the nasturtiums have wisely tucked their flowers under their leaves, so that few of them are in sight. The border plants are deluged up to their heads in water, while the vines on the wall have a limp, retreating look. I scarcely have ventured to look towards the rose fan. But the phloxes are standing the storm remarkably well. They seem to say: "Come on, good rain, we have been without you long enough not to criticise your roughness now that you have come."

It is not only that the rain is falling heavily this morning, but the wind is howling over the garden as I have never heard it before. Even our house trembles now and then in response to its batterings. 
This, however, does not alarm Joseph and me. It has stood here too long and weathered too many gales to topple over now. But by the wood-border we hear crack! crack! and know that the limbs of trees are falling.

"Have they struck the hepaticas?" Joseph asks. "Do you think the wild gingers are injured?"

I cannot answer. It is alarming to think what such a storm as this can do.

One curious thing is the way the storm appears to have taken the colours out of the garden. The yellow poppies, which have been like flecks of gold, look grey and dull.

"Will it last long?" Joseph asks anxiously, and I answer, "I do not know."

The poor birds! where have they gone? There is not a sign of one anywhere. The bird-houses are swinging from the trees as never before, so I do not think they are inside. Probably they have hidden themselves somewhere under the leaves of the trees.

"The only birds that would feel at home in our garden now," Joseph says, "would be water fowls."

We left the window to take breakfast, during which time the wind howled piteously in the chimney. Perhaps we should have noticed it less had it not been for the garden.

"Timothy Pennell was right," Joseph said to Mrs. Keith. "The rain is here in less than twentyfour hours." 


\section{THE END OF THE DROUGH' 181}

"It will be gone soon," she stated. "It is too heavy to last long."

This was encouraging news, although just at that moment it was coming down harder than ever. Then lightning sped through the sky and a great roll of thunder passed overhead. I have never liked lightning, not that I am afraid of its striking me, but it makes my head feel as though a tight band were drawn about it.

"If it is as sharp as that this evening," Joseph said, "we must try to photograph it."

"The lightning?" I asked. I felt indeed more like taking refuge in the dark closet.

"It is stupid to be afraid of lightning," Joseph said. "Mr. Percy has told me how to photograph it when it comes in the evening. I am sure, if you once try to do it, you will never be afraid of it again."

"It has struck near-by," Mrs. Keith called sharply, as again another roll of thunder followed the lightning. "It has struck one of the spruces!" she cried, having gone to a front window to look out.

Joseph and I did not know what to do. We would rather the storm had devoured the whole garden than to have had it harm one of the six spruces. But what Mrs. Keith said was true, although we could not see then how much damage had been done. We wondered if the storm had had the special intention of killing one of our 
spruces, for immediately after the work was done it began to subside and the sky to clear. A tiny bit of blue appeared overhead, and gradually spread until it occupied a considerable space in the sky. Instead of falling as one solid sheet, the rain now came gently. We could almost count the drops. The wind also calmed down and blew lightly, as if, having had its mad fun, it was ready to assist things in getting dry again.

But the striking of one of our spruces had so depressed Little Joseph and me that we found it hard to rejoice in the clearing of the storm.

"Perhaps the damage will not prove so serious after all," Mrs. Keith said. "Timothy is a splendid hand at doctoring trees. Once that old locust tree near the gate was struck; but he managed to keep it alive, although since then it has never been as beautiful as before."

Almost before she had finished speaking, we noticed Joseph running across the front lawn to the six spruces. He had slipped out without our seeing him go. We called him, but he did not hear. When he came back, he said that the trunk of the tree had been burst open, just as if something inside of it had exploded. He was sure it could not live. Mrs. Keith urged again that we must not despair until after we had heard what Timothy had to say. on the subject.

Joseph then changed his clothes, for even his short run out-of-doors had soaked him completely, 
and at once began to read in "An Ambitious Boy's Garden." I think he was trying to forget about the poor spruce. I rearranged the flowers in the house, clipping their stems and giving them fresh water, a thing, in fact, I do every morning. At length I looked out at the garden, Joseph being still deep in his book.

The first things that caught my eyes were the yellow poppies, the ones that grow on the highest part of the slope towards the woods. They were not in the least injured by the storm. Instead, their golden cups gleamed as high and bright as ever. It seemed as if they were climbing towards the sun. I looked long at these poppies, recalling how abundantly Joseph had scattered their seeds when we were still fearful of frosts; how busy he was at one time thinning them out, so that only the strongest plants should be retained; and how, as they grew and bloomed, they changed the whole look of the places about them. Great drops of water were still lingering on their leaves and flowers.

It seems as if these California poppies had wished to bloom themselves to death. How they will look after they have gone to seed, I do not know. Surely, Joseph will not have to buy poppy seed another spring. I can see that their pods hold it in plenty. He will gather from them all he has need of, while they will very likely assist him by resowing themselves. Next spring Joseph 
will merely have to rake and soften the surface of the ground where they have been to give them a chance to come up.

From these yellow poppies I glanced towards the Shirley poppies lower down the triangle, near the moist point. In spite of the rain, they also were holding themselves up fairly well. Yet, as I looked at them closer, I saw that havoc had been made among their flowers. The ground beneath them was strewn with their tissue-like petals. Only the blooms that had barely opened were left to show their colours. These Shirley poppies began blooming before the yellow ones. Yet I do not think that Joseph sprinkled their seeds any earlier in the season. Probably it is their habit to be quicker in what they do.

Joseph has the greatest fancy for Shirley poppies, as I think every one must who has a garden. At first his disappointment was keen, because it seemed useless to cut them for house bouquets. They wilted at once. Now, however, we have learned from Miss Wiseman the right way to gather them, that they may hold up their heads for at least two days. We take a large bucket of hot water to the bed, as we do when picking heliotrope, and plunge the stems into it deeply as they are cut. Usually we let them remain in this water for about an hour, or until they are thoroughly soaked. After that I arrange them in tall vases. We pick only the flowers that have newly opened, 


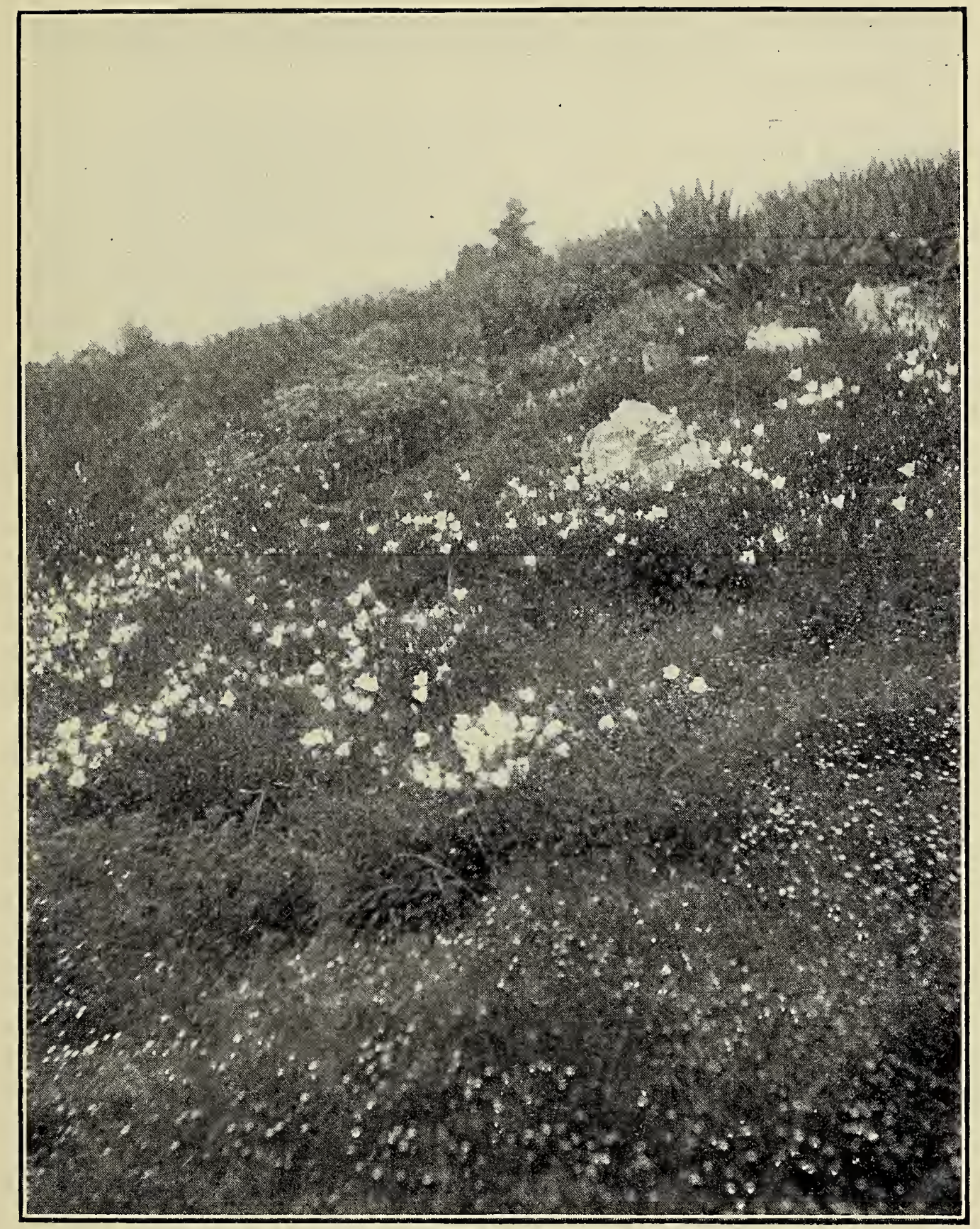

PLATE XXX.- "THEIR GOLDEN CUPS GLEAMED AS BRIGHTLY AS EVER" 

and usually do it early in the morning while the dew is still on them.

When these beautiful Shirley poppies have finished blooming, Joseph intends to pull them up, and to plant in their places some of the late asters that are now growing in the seed-bed. In gardening, I notice, one has not only to do the spring planting, but, after certain flowers have bloomed, they must be taken up, that their places may be filled with others.

The rain played sad tricks with the cosmos, the golden glow and the hollyhocks. It may be that Joseph will be able to lift them up from the ground, where they now lie prostrate, and to tie them again to their stakes. I need not have had so much fear about my rosarium. The bushes have stood the gale splendidly. And the heliotrope, although considerably flattened, is already beginning to raise itself, looking wonderfully fresh and sweet.

In some way of its own, the wind must have taken hold of the climbing nasturtiums and torn them down from the wall, while the other vines have been disturbed but little. Truly, the storm has shown originality, in leaving some things and destroying others. The prim phloxes appear as smiling as formerly, while one of our great spruces will probably die.

On the whole, I thought it fortunate that not more damage had been done by the storm in the garden. I did not venture along the wood-border, 
since there it was still extremely wet, but I returned to the house to cheer Little Joseph.

$\mathrm{He}$ was not reading "An Ambitious Boy's Garden," as when I went out; but entertaining $\mathrm{Mr}$. Hayden, who had returned early in the morning from the mountains, and who then had hastened to the Six Spruces, he said, to hear how we had stood the gale. It did seem remarkable that he should have come back with such rain and wind. All the time he had been away there had scarcely been breeze enough in the garden to toss a dead leaf, while with his return there had come a hurricane. Joseph and I began to think there was some reason outside of our joke in having thought $\mathrm{Mr}$. Hayden so like the wind.

$\mathrm{He}$ and his boys had enjoyed themselves in the mountains, he said, but he was glad to be home again. Joseph had told him about the spruce tree before I came in from the garden.

"The whole character of Nestly will change," he said, "if one of those spruces falls. You had better let me talk with your man Timothy about what can be done."

Just why Mr. Hayden had wished to do so, neither Joseph nor I understood. He is, however, a man whom it would be impossible to refuse anything. 


\section{CHAPTER XXIV}

THE FALL OF ONE OF THE SPRUCES

LTHOUGH offered all sorts of rewards by
Mr. Hayden, Timothy could do nothing to save the sixth spruce tree. The gardeners from Nestly Heights came to look at it, and also $\mathrm{Mr}$. Bradley from Miss Wiseman's. They all talked together, and then together they shook their heads. The stroke of lightning had entered at the base of the tree, and had then run up the stem and burst it open. The wound was too great to heal. This has been our first grief at the Six Spruces. Even Mr. Hayden did not venture to speak of our Aunt Amanda. As yet the tree has not fallen, but some day, when Joseph and I are away, Timothy is going to take it down.

Our garden cheerfully rebounded after the storm, and the birds returned in great numbers, appearing hungrier and more active in catching worms than before. Even the screech-owl made his moaning noise from the wood-border in the evening, to assure us perchance that he had not been drowned.

The foxglcves in the garden are still very lovely. 


\section{FALL OF ONE OF THE SPRUCES}

They began to bloom in June, and now in late July they still hang abundantly with their drooped bells. It was Joseph's intention to have no biennials in the garden, since the greater number of them must be taken care of for two years before blooming, dying directly afterwards. Foxgloves, however, are hardy biennials, and although they do not bloom until the second year of their growth, they then are considerate enough to sow their seeds for another year.

We should have had no foxgloves this year had it not been for Miss Wiseman. She gave us a number of plants that were raised from seed last year, which therefore were ready to send out their first summer blooms for us at the Six Spruces. They were a trifle slow in getting started, perhaps on account of their spring transplanting; but when once under way, they grew well, and since then have delighted us with their blossoms.

Our flowers are mostly pale lavender, although a few of them are white. The plants stand about three feet high. We have them placed not far from the larkspurs, where there is an abundance of green. Every time I look at them I think them prettier than before.

"We must always have them in the garden," Joseph says, "now that we have become acquainted with them."

To keep them with us he will first let them seed themselves in their own way. This means that we 


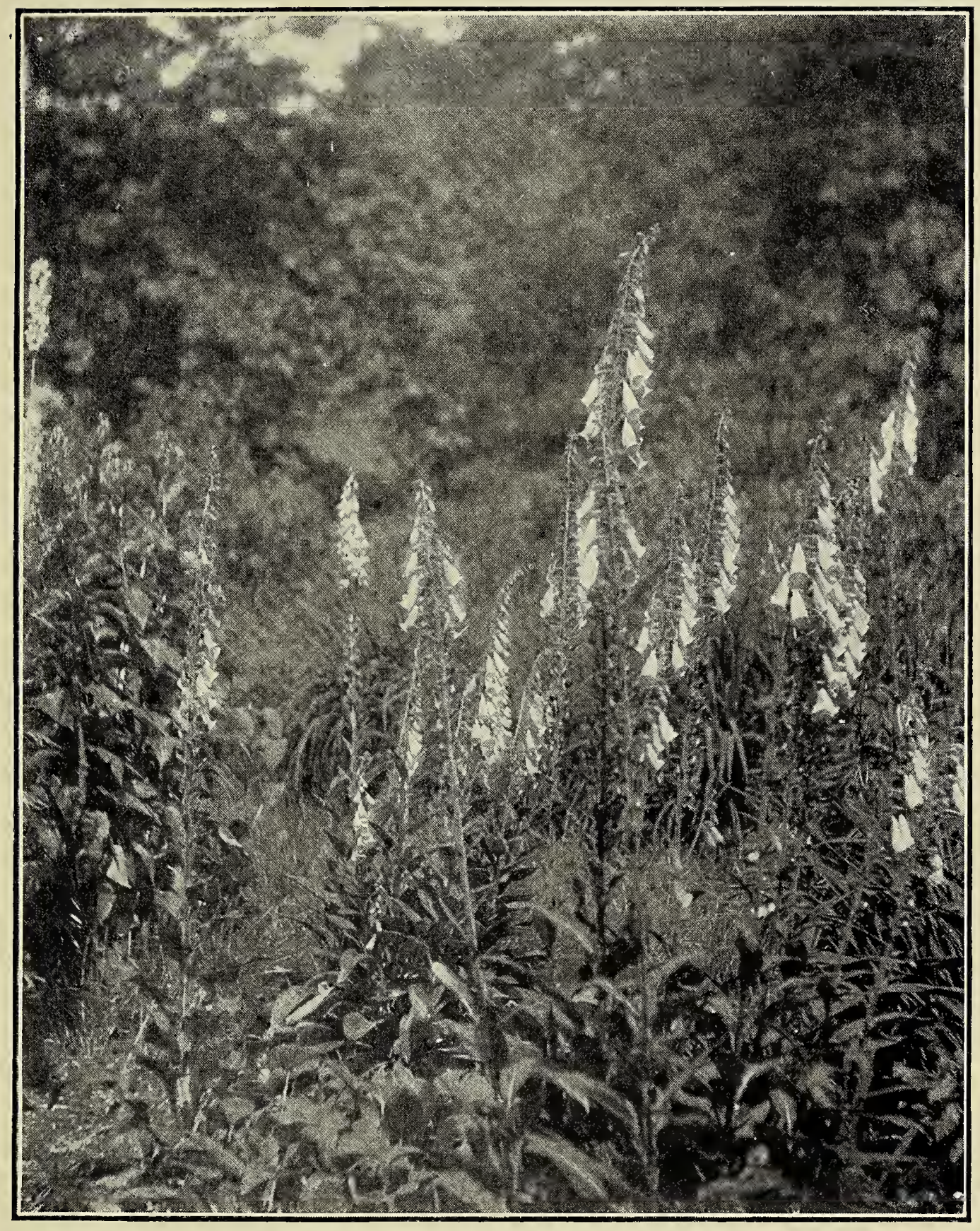

PLATE XXXI.— "THE FOXGLOVES ARE STILL LOVELY" 



\section{FALL OF ONE OF THE SPRUCES 189}

must not pick their stalks of bloom for the sake of having flowers in the house. In the spring, when the little plants appear, he will transplant them to some place where they can grow as strong as they please. Having sown their seeds in the autumn, they will bloom a little even this first year, although the plants will not be very tall. Then, about the last of September, Joseph will again take them up, and put them in the places where he wishes them to appear at their best the following summer. When he sets the young plants out to grow, he will put them about six inches apart in a trench made rich by having had a layer of manure placed under the soil, and he will keep the earth about the roots quite moist.

We have no canterbury-bells in our garden. They also are hardy biennials, and quite enchanting. We have admired them at Miss Wiseman's and at Nestly Heights. Next spring Joseph will probably put a few of their seeds in the bed, and afterwards treat them in the same way that he does the foxgloves. It will not be much more trouble, he says, for him to raise both foxgloves and canterbury-bells than it would be to grow one or the other of them alone.

There is about these flowers a sweet, old-fashioned air that we like to see in our garden. I tell Joseph we must never try to make things appear as formal here as they do at Nestly Heights.

To-day we are going to Mr. Hayden's for 


\section{FALL OF ONE OF THE SPRUCES}

luncheon, after which I suppose I shall walk in the garden with Mr. Hayden and Mr. Percy, while Joseph plays tennis with Ben and Harry. Mrs. Hayden is very kind when we are there, and is especially fond of Joseph; but she is a delicate woman, and seldom walks farther with us than the first terrace.

I was most surprised when I saw Joseph ready to go. He had on a very silky necktie, of a red as bright as it possibly could be. When he saw my eyes fastened on it, he said that Queenie Perth had knitted it for him and that she had brought it over early in the morning. It was beautifully made. I do not think I could have done it so well. Long ago, Joseph and I found out that Queenie has a great deal in her head besides chasing butterflies. She is a very helpful and wise little girl. Sometimes she says things that sound quite like her aunt, but this is undoubtedly because she has been with Miss Wiseman constantly, and had few playmates. This summer she has grown a good deal, and is much stronger than she was when we came to live at the Six Spruces.

As I supposed we would, after we had had luncheon we began our walk about the garden. Besides white, there are only yellow pansies at Nestly Heights. I have never before seen so many white pansies as were there to-day. Mr. Hayden says this is a new notion of his up-to-date gardener, and that it does not please him at all. He prefers to 
see pansies of nearly every colour under the sun. I rather liked the idea myself of using pansies of the same colour for border plants. The yellow borders are very effective, while the white ones have a pure, lovely air of their own. Pansies are infinitely prettier, to my taste, when planted in this way than when used to carpet rose-beds, a treatment about which much has been written. The plants are kept blooming prolifically by having their flowers picked off every morning. This must be a great work when one has so many hundreds of them as there are at Nestly Heights.

At the Six Spruces, we have had but few pansies, the ones given us by Mr. Hayden. Next year, however, I should like Joseph to plant a border of yellow ones in front of the flame-coloured azalea. This would make a lively spring spot by the triangle.

In the house at Nestly Heights, white pansies were arranged in low bowls of white porcelain, and yellow ones were in yellow bowls. I also saw tuberoses and the waxen bells of Adam's-needles placed in white dishes. Mrs. Hayden told me that she liked to see flowers better than the porcelains which held them, and therefore she tried to have the bowls as inconspicuous as possible. When I told this to Joseph he liked the idea.

We have no tuberoses in our garden. These plants seem especially designed for Nestly Heights. Dahlias, cannas, salvia and gladioli are also seen 


\section{FALL OF ONE OF THE SPRUCES}

there in numbers, while we have none of them. I admire the gladioli very much. The flowers of the improved varieties are large, velvety, and occur in almost every colour. But these plants require a great deal of care, while Joseph's idea is to have a hardy garden that will to some extent be able to care for itself. Some time in the spring perhaps we shall try to set out a large bed of salvia in front of the house. It looks cheerful in the autumn, when other flowers have died. The salvia at Nestly Heights to-day almost outshone Joseph's necktie.

Mr. Hayden showed me his flowers with a great deal of pride. He said he took a book about them away with him to the mountains, and he had learned so many scientific names that on his return he quite amazed his son Percy. We have noticed often that Mr. Percy is very quiet whenever his father begins to talk about flowers. At Nestly Heights the gardeners had so completely removed all traces of any damage done by the great storm that one might think it had never been.

"How odd it is," I said to Mr. Percy, "that three gardens can be so different as this one, Miss Wiseman's, and Joseph's. They are all made with flowers and many of the same shrubs."

"I should choose Joseph's," Mr. Percy replied promptly, and I thought this a very great compliment.

"It is freer," he continued, "and more natural." 
I was thinking that I would remember to tell Joseph what he said, when a lady-bug flew on my hand.

"Do not kill it," Mr. Percy said quickly, although in truth I had not thought of doing so. They do no harm themselves, while they eat up some of the miserable mites that annoy roses. When we passed a rose-bush I put the lady-bug off on it to do as much eating of this kind as it desired.

Mr. Percy next pointed out to me a large whiteoak tree. The day before, the men had taken off one of its limbs, badly broken by the storm. The tree proved to be somewhat hollow, and within they had found a nest of flying squirrels. Unfortunately, they had to be routed, as the broken part was to be filled and sealed. Mr. Percy, however, had found them another home in the hollow of an old tree at the back of the place. It would be useless, he said, for us to try to see them. Like the screech-owl, they are nocturnal in their habits, only coming out in the night. This I regretted, as neither Joseph nor I have ever seen flying squirrels.

It was rather late when we left Nestly Heights, Joseph having stayed so long to play tennis. $\mathrm{He}$ had no time to walk in the garden, nor did he seem to care much. In fact, I have often wondered whether Joseph would be fond of flowers if he had not to do the gardening himself.

On the way home we had to stop a few minutes at Miss Wiseman's, so that Queenie might see how 


\section{FALL OF ONE OF THE SPRUCES}

well the knitted necktie became Joseph. There was much to talk about, and the twilight was not far off, when we went through our front gate. Long shadows from the trees then lay over the lawn and stretched across the driveway. They were not so deep, however, but that we could see the gap among the spruce trees. We said nothing, knowing that Timothy had done his work. 


\section{CHAPTER XXV}

\section{OUR GOLDEN GLOW AND HOLLYHOCKS}

WHEN the frost was out of the ground in the spring, one of the first things that Joseph did was to spend two dollars in buying twenty roots of golden glow. He planted them at the back of the long bed of the triangle in front of the wall, and paid little attention to them, until suddenly in the middle of July they startled us by crowning themselves with double golden heads, flaunted high in triumph. We had noticed before this how tall they were growing, and Joseph even had staked them to keep the wind from blowing them over. Still, I had thought little about them. They were hiding nothing but the wall as they grew in their tall greenness, and I thought they had been planted for this purpose. Indeed, I had quite forgotten they were golden glows until they showed it to me in terms unmistakable. Now they are fully repaying Joseph for his expenditure and labour.

Golden glows are delightful, I think, when looked at from a distance. They then make every- 


\section{GOLDEN GLOW AND HOLLYHOCKS}

thing near them appear sunny. As I go close to them, however, I care less for them. There is something a trifle coarse about their flowers. I do not wish to gather them to take into the house, although their flowers last well in water throughout a week. Almost every place in Nestly has golden glows. Even the very poor have them somewhere about their homes. I think people like them because they appear so cheery, and surely no one could feel long dreary while looking at their masses of yellow.

Joseph had heard that golden glow roots should be divided every other year. They increase so rapidly that people soon have more roots than they wish to take care of themselves. The surplus they give away, which accounts, perhaps, for the abundance of golden glow about Nestly.

Yellow is always a beautiful colour in a garden, gleaming brighter than any other. It calls people to look at it. I do not know just why, but Joseph always seems a little miffed when I talk much about yellow.

To-day, while he was looking at the smoke-tree that Miss Wiseman gave us, to see how nearly ready it was to flower, he spied a nest in which four baby catbirds were holding open their mouths in expectation of their parents' return. We then knew why we had so often heard the catbird's alarm cry about the garden. This cry the bird gives in imitation of a cat, and is not its real song at all. 


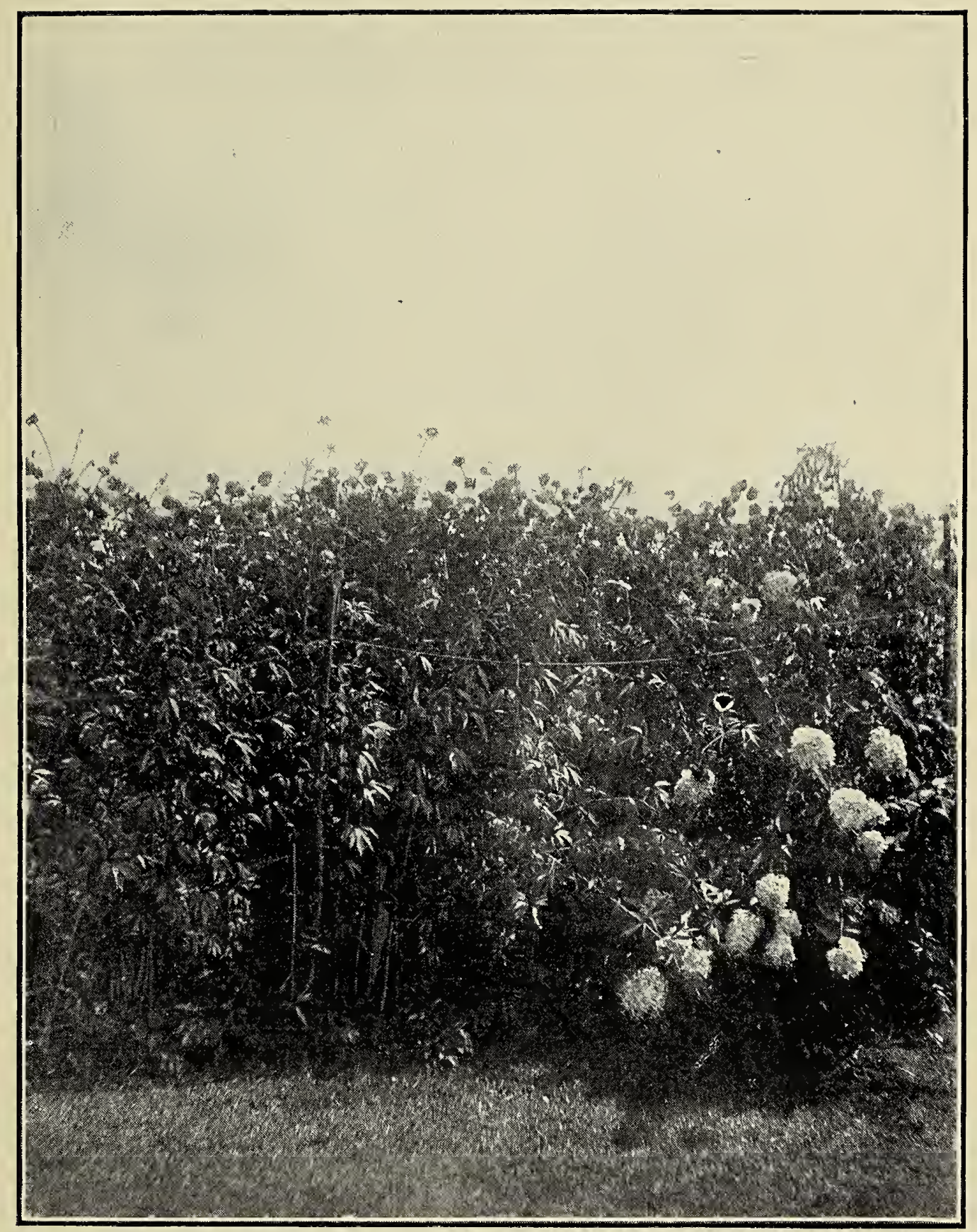

PLATE XXXII.-"GOLDEN GLOW AGAINST THE SKY" 

Long ago, Mr. Percy explained the mattter to us. We heard a bird singing one day, and he told us to stand and listen. We could scarcely believe it was a catbird, yet we saw him plainly at the tip-top of the smoke-tree. The song was lively and brilliant, full of quirks and strange notes, so rapid and varied that I cannot describe how it goes, although Joseph has learned to imitate it quite successfully.

Any boy or girl who sees a catbird should not rest until his true song has been heard. It is an injustice to think he can sing no better than his sharp, unpleasant cry would indicate. The day we had the great storm we heard these birds continually crying like cats. Their cry, however, is not a mew; Mr. Percy says the sound to him is more like zeay! zeay!

The catbirds are as familiar with our garden as the robins, wrens and other birds. Often one perches on our great-aunt's blush-rose bush and gives us a twilight concert lasting nearly an hour. We have always thought that this particular catbird was the one whose nest we found some time ago in one of the lilacs by the stable. It had in it six eggs of a clear, greenish blue.

The birds of our garden spend their days feeding their young, as soon as they are out of the shell. Consequently, the number of worms and insects they consume is considerable. As these creatures never have very charitable designs on our plants, we are more than pleased to have the birds devour 


\section{GOLDEN GLOW AND HOLLYHOCKS}

them. Joseph would like to take one of the young catbirds to bring up in the house, if it did not seem so cruel to deprive it of its free life in the open. Besides, the parent birds might take alarm at such a case of kidnapping and not return to live near us another spring.

Mr. Percy believes that catbirds become great thieves near a fruit garden; but as we have only a few old apple-trees at the Six Spruces, this has not changed our desire to have them remain our neighbours.

The hollyhocks that Joseph bought are all single ones, and since about the middle of this month they have been doing their best to show us their varied colours. We have them white, pink and crimson, and a few that seem undecided whether to be pink or yellow. They, therefore, have taken both colours, and now appear in something like the tint of apricots. I do not think that our hollyhocks have bloomed as well as those at Miss Wiseman's, perhaps because they are younger plants. Ours are scarcely taller than Little Joseph, while few men are as tall as those in her garden. Joseph took care to plant them at the very back of the long bed, where he thought they would grow tall enough. to look over the wall. As soon as their seeds are ripe he will gather them, that they may dry thoroughly and be ready for him to sow in the seed-bed. Perhaps by October the seedlings will be large enough to transplant to the places on the triangle 


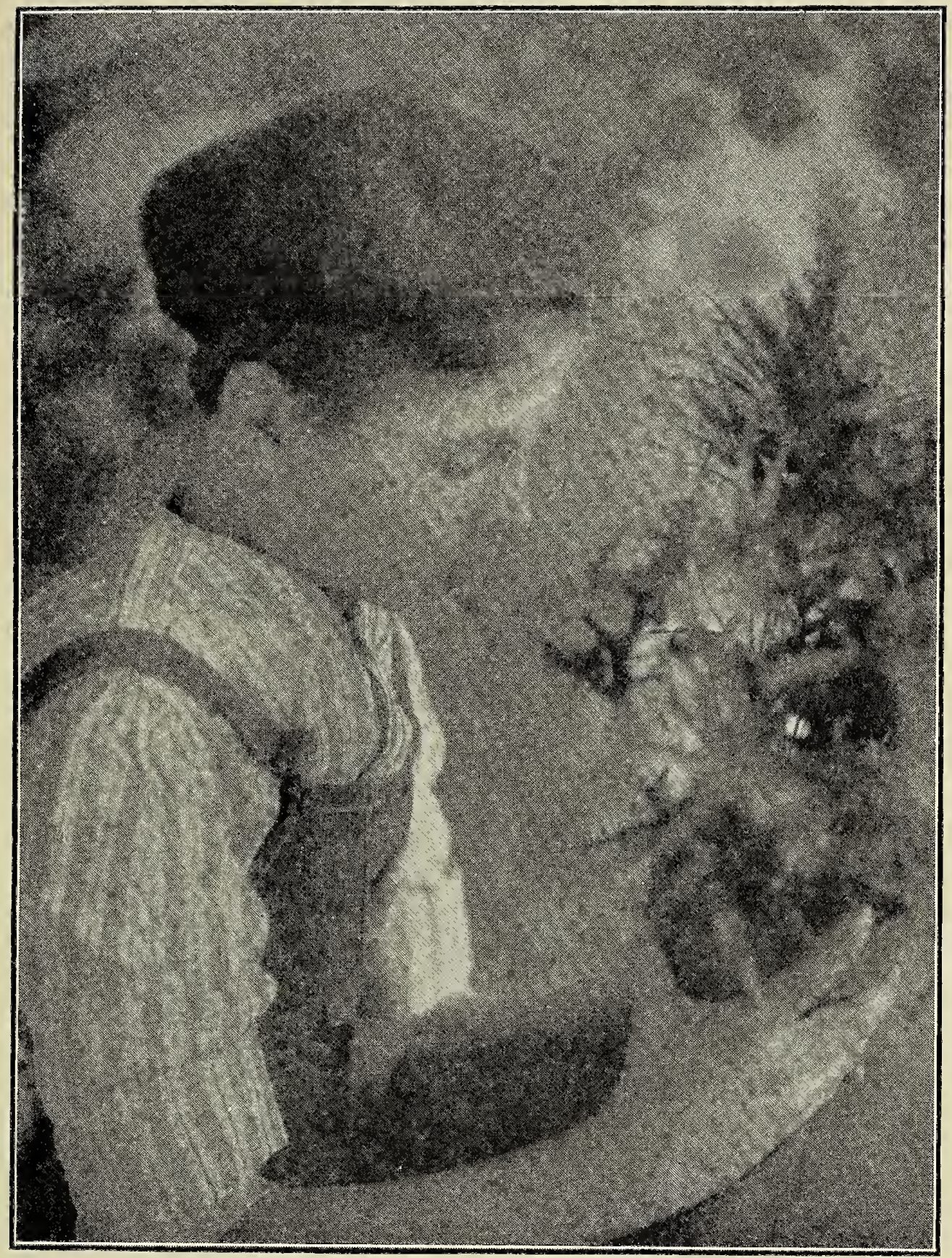

PLATE XXXIII.- "HE KNOWS WITHOUT BEING TOLD JUST HOW
TO HANDLE A PLANT"

Photograph by Alice Boughton 



\section{GOLDEN GLOW AND HOLLYHOCKS 199}

where he wishes them to bloom next year. These young plants will be somewhat tender the first winter of their lives, so he will cover their roots over late in the autumn, to keep them from being nipped by Jack Frost.

How much there is to think about in a garden! I listen in amazement to the many things Joseph tells me, and cease to wonder that the neighbours think him a bright boy. He has not learned all that he knows from "An Ambitious Boy's Garden." I think Miss Wiseman and Mr. Percy have helped him more than all the books and catalogues he has read. This is because they have observed little details for themselves when watching flowers. They know their individual habits, and do not have to follow such set rules as are laid down for beginners in gardening. Mrs. Keith says she never has learned a rule about planting a flower in her life, but that she can make them grow because she has "a way with her." This is true about some people. Flowers grow for Little Joseph, and the triangle this year has astonished every one. Some boys, on the contrary, have little success when they make their first gardens. Sometimes I think there is witchcraft in Joseph's fingers. He knows, without being told, just how to handle a plant and how. deep to set it in the soil. He knows often how to prune it, and how to gather and sow its seeds. I fear I am not by nature half so expert a gardener as Little Joseph, but, apart from the rosarium, my 


\section{GOLDEN GLOW AND HOLLYHOCKS}

work is mostly to help, and to cut and arrange the flowers for the house.

This morning, when I went with my basket and clipping-shears down by the hollyhocks, I saw that several of the silken flowers were fairly covered with large spider-webs. The weaving was without a break, and of a symmetry more wonderful than the work of most men. How did the spiders know how to weave so beautifully? I wondered. Just then Queenie Perth came to answer the question as best she could.

"They know how to spin that way," she said, "just as you know how to go to sleep. No one has to show them."

This seemed quite true. The spiders that had made these webs were very ugly. We did not disturb them, since neither Queenie nor I knew whether they were harmful to the hollyhocks.

In the rose fan I later spent an hour picking off bugs. No matter how exquisite a nest or web these creatures might make, I still should remain their enemy. It is a mystery to me why these bugs exist. I know no good that they do, and they greatly harm the roses. In the very heart of a Perle des Jardins I found one munching. It may be that their purpose is to test the patience of rose-growers, the way potato-bugs try the vigilance of farmers. I would give up eating potatoes sooner than wrestle with these bugs, while no pest will ever be able to make me forsake my roses. 


\section{GOLDEN GLOW AND HOLLYHOCKS 201}

The fan is no longer aglow with roses, even the Clios having shed most of their flowers. Here and there, however, a lovely monthly rose is unfolding. Only yesterday I gave Timothy Pennell a large bunch to take home to his son. The only ones that Mrs. Keith will ever pick to give away are those from Aunt Amanda's bush. She says all her old friends know those roses belong to the Six Spruces.

We still call our place the Six Spruces, although there are now but five. Yet the fallen tree lived its life among the others, and it would seem wrong to stop counting it now, just because that dreadful stroke of lightning prevented it from staying longer. Some day, I suppose, all the trees will die and their places be taken by others.

I am glad that we have a mignonette, lemon verbena and maidenhair fern in our garden. When I arrange the roses, I put little sprigs of these among them, and I always choose a sweet-smelling green for flowers that have no fragrance. Mr. Hayden seldom comes here without picking a bit of lemon verbena for his buttonhole. Some days he returns with an old piece looking much dried and dead, and exchanges it for a fresh bit. He says that whenever he really wishes a thing he comes to the Six Spruces. Now, both Joseph and I know that there is an abundance of lemon verbena planted at Nestly Heights, but we suppose $\mathrm{Mr}$. Hayden has never discovered its whereabouts. The 


\section{GOLDEN GLOW AND HOLLYHOCKS}

gardens there are so large and so many kinds of flowers are planted in them, that it is rather confusing.

I cannot imagine either Joseph or me not knowing where our flowers are planted, whether they are looking vigorous, whether their blooms are at their height or fading, and all about them. I think we could walk to any one of them with our eyes shut. So, even though our garden is small and new, we know it intimately, and in this feeling there is surely more pleasure than in having to ask a gardener the way to the lemon verbena, and to ask whether it is permissible to pick a few sprigs.

In time, perhaps, our garden will grow large, and we shall have many kinds of plants that we have not now. I hope, however, that we shall never lose sight of our dear favourites which have helped to make our first year's garden so beautiful. 


\section{CHAPTER XXVI}

WATER GARDENS AND OTHER THINGS

THERE is one kind of a garden that interests Joseph and me as onlookers. This is a water garden, or, more plainly, a small pond with lilies floating on its surface, and numbers of waterloving plants thriving about its edges. At Nestly Heights there are two such water gardens. Happily for Mr. Hayden, the ponds were formed naturally, and he had but to make them beautiful by planting appropriate flowers in and about them. Here, however, there is no pond, and to make one at the moist point of the triangle would be too costly an undertaking for Joseph and me.

Mr. Hayden is fond of his water gardens. $\mathrm{He}$ can even relate the scientific names of the pink, blue and yellow lilies which float on their surfaces, not far from the wonderful lotus, making ready to bloom. Except for the different colours of these water-lilies, they appear just like the sweet white one, which is known to every boy and girl. Yet they are different from the common pond-lily in not being hardy. When Joseph and I peered down 
into the water of the ponds, we saw that their roots were set in large tubs, which have to be taken up before cold weather and housed over the winter. They are among the rare garden treasures that Joseph and I know we shall never have.

About the borders of these ponds, I have noticed other plants that are not rare, but which appear very beautiful by the side of the mirror-like water. One of these plants growing in great masses is the pickerel-weed. It is a common wild flower, for Mr. Percy and Joseph saw it by numbers of ditches and little streams one day when they were taking a walk in the open country. Countless irises grow by these ponds; and after their bloom has passed, the effect of their tall, sword-like leaves reflected in the water is most enchanting. High along one of the banks the Wichuraiana rose has spread itself into a sheet of bloom. It reminds me of our own rose-weed at the point of the triangle, for the Wichuraianas, like the morning-glories, have fallen into the ways of bad weeds. Many large clumps of showy grasses near these ponds help to make them among the most attractive spots of Nestly Heights.

After looking long at these water gardens, I hinted to Joseph that perhaps next year we could make the moist point of our triangle more conspicuous than it has been this season. If we had not only a few, but quantities of irises there, it would be an improvement, and we should have more 


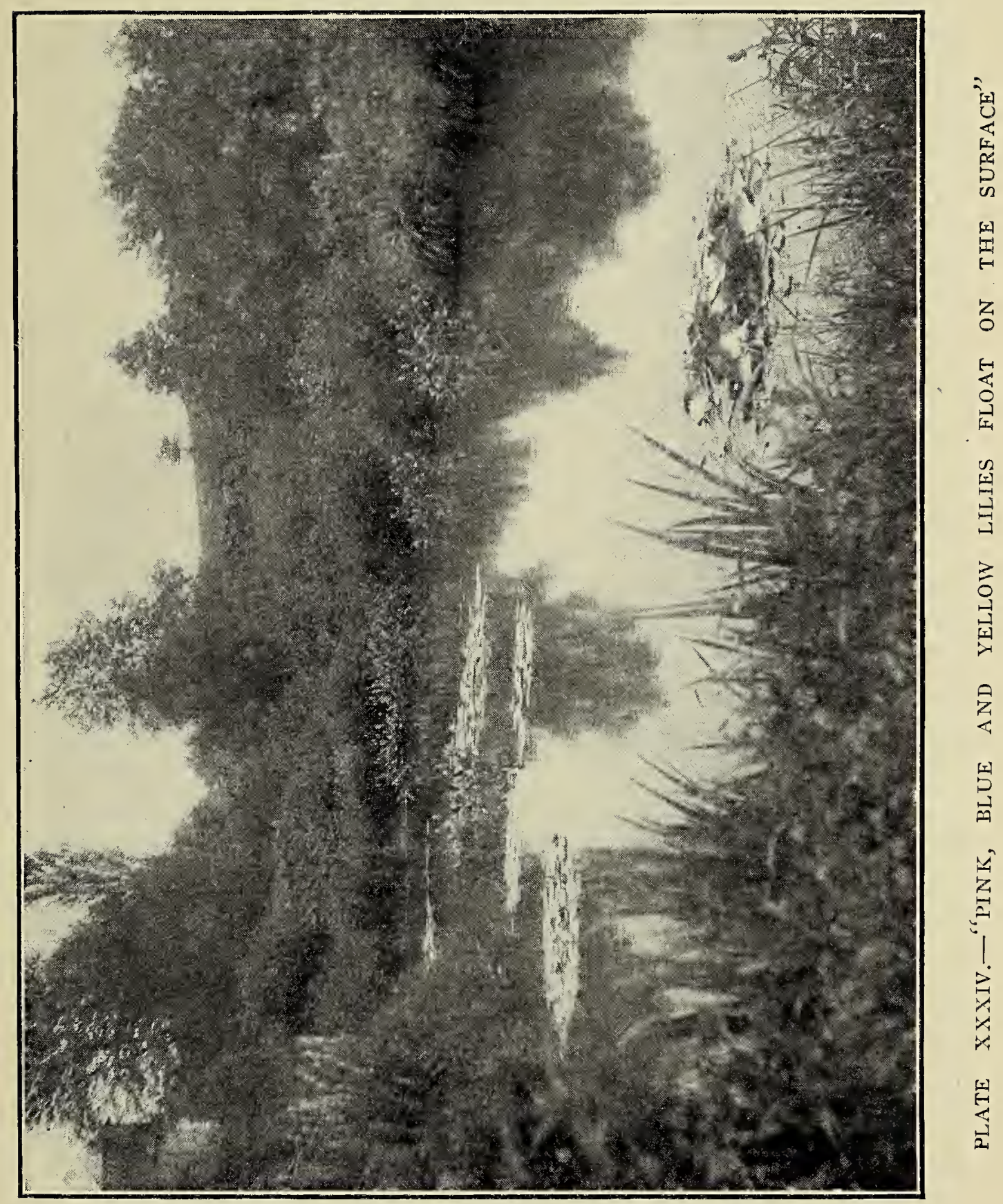



ferns another season than just the few that Mr. Percy transplanted for us. I also should like to see there several clumps of the tall, featherylooking grass called eulalia japonica, or Japanese plume grass. As autumn draws near, this grass appears at its best, and the plumes sometimes stay on all winter, if not planted where too high winds will attack them. Already we have one such clump of grass in our garden, but I should like to see several about the place. As yet, I have not found out how much money these additions would require, nor even whether, as Joseph says, they would be practical. Next year, however, as I shall not have to spend so much capital on roses, I may put it all into plants for the moist point of our garden. This was the spot where things kept freshest during the long drought. One day, perhaps, we may find that there is a tiny spring lurking somewhere under the ground.

Even now at the moist point we are expecting a brilliant show of cardinal-flowers. These are the plants that Joseph watched and waited for at least six or seven weeks before they peeped up through the soil of the window-box. After that, they grew quickly, vying with each other for space. Since the day that Joseph set them out in the garden, however, we have thought little about them, until now that they are almost ready to bloom. Nothing about them appeared in the least unusual to Joseph or me until yesterday, when Mr. Percy, who 
was here to ask about them, exclaimed: "I declare! you have managed to turn them into annuals!"

We knew then that he was amazed that Little Joseph had succeeded in making them bloom this first year, which, as perennials, they are not in the habit of doing. Perhaps this change in their ways was effected because Joseph sowed the seeds early in the season. Although, so far, only one flower has peeped out, I can see that it is of as beautiful a red as there is in the whole world. Mr. Percy says that it will last in bloom a month.

We have all been much pleased with Joseph's successful planting, and are enthusiastic about the cardinal-flowers. Later, we are going to a moist meadow not far away to take up some of the wild plants and see whether there is any difference between them and those that Joseph has grown. The real home of cardinal-flowers is in wild places. $\mathrm{Mr}$. Percy says he has never seen them so beautiful in any garden as they are by the side of a certain stream he knows, and whence they spread out into the meadow.

On the ground about their base there are also many wild forget-me-nots, blooming at the same time and trying to get as near the stream as possible. Sometimes they grow even in the stream, where there is quite a little current running over them.

For several weeks now, none of us has been much in the woods or meadows. I was glad, therefore, 
to hear Mr. Percy plan some tramps which we shall soon take. He has ideas also about transplanting more ferns to the Six Spruces, although this cannot be done until the late autumn.

Judging from the many things that Joseph has set down in his note-book to do this autumn, I begin to think that July and August must be the real playtimes of a garden. In these months we have chiefly to look after the plants that are blooming, while in the spring and autumn preparations must be made for following seasons. I do not mean that Joseph has ever found time to dream and idle over the garden, but at present such work as weeding and staking plants is somewhat less arduous than heretofore. Once I was almost bold enough to feel that Joseph had conquered the weeds. I mentioned it under my breath, fearing they might hear and again start up their mischievous pranks.

The season, we are told by our neighbours, has been a kind one in the way of insect pests. They have not been so annoying as to cause discouragement, nor have they been especially numerous. Joseph has, nevertheless, been continually on the watch against them, keeping the plants well sprayed, while about the base of many he has put wood ashes. We think also that having so many birds about the triangle has helped to keep the pests under control. Next year we may have even more birds, since the little ones that have been raised and have spent their youth here, will per- 
haps return in the spring, after their winter migration, to settle down and make nests for themselves.

Something that we have found out about the phobe-birds makes us think we can do without them at the Six Spruces. We did not even know their names when they began building under the roof of our back veranda, until Mrs. Keith said: "Those miserable phœbes are here again." Joseph and I would not let their nest be disturbed. Our hammock was swung near, and it was interesting to have the young raised where we could look at them each day.

These phobe-birds belong to a class called flycatchers. Their habit is to perch themselves somewhere, as on the top of a roof or a clothes-pole, to fly off suddenly after some insect passing innocently in the air, and to return again directly to their former perch. This they accomplish with great quickness, and with an aim so sure that few insects escape them. It pleased us to watch them for long times together, and we were delighted with their quaint cry of phobeë! phobe $\ddot{e} !$

One day, when the young in the nest were well grown and continually stretched up their brownish grey heads for food, I was lying in the hammock reading. Over the garden all was peace. Joseph was at Nestly Heights, playing tennis with Ben and Harry.

Suddenly my hands began to smart and itch uncomfortably. When Mrs. Keith came out, she 


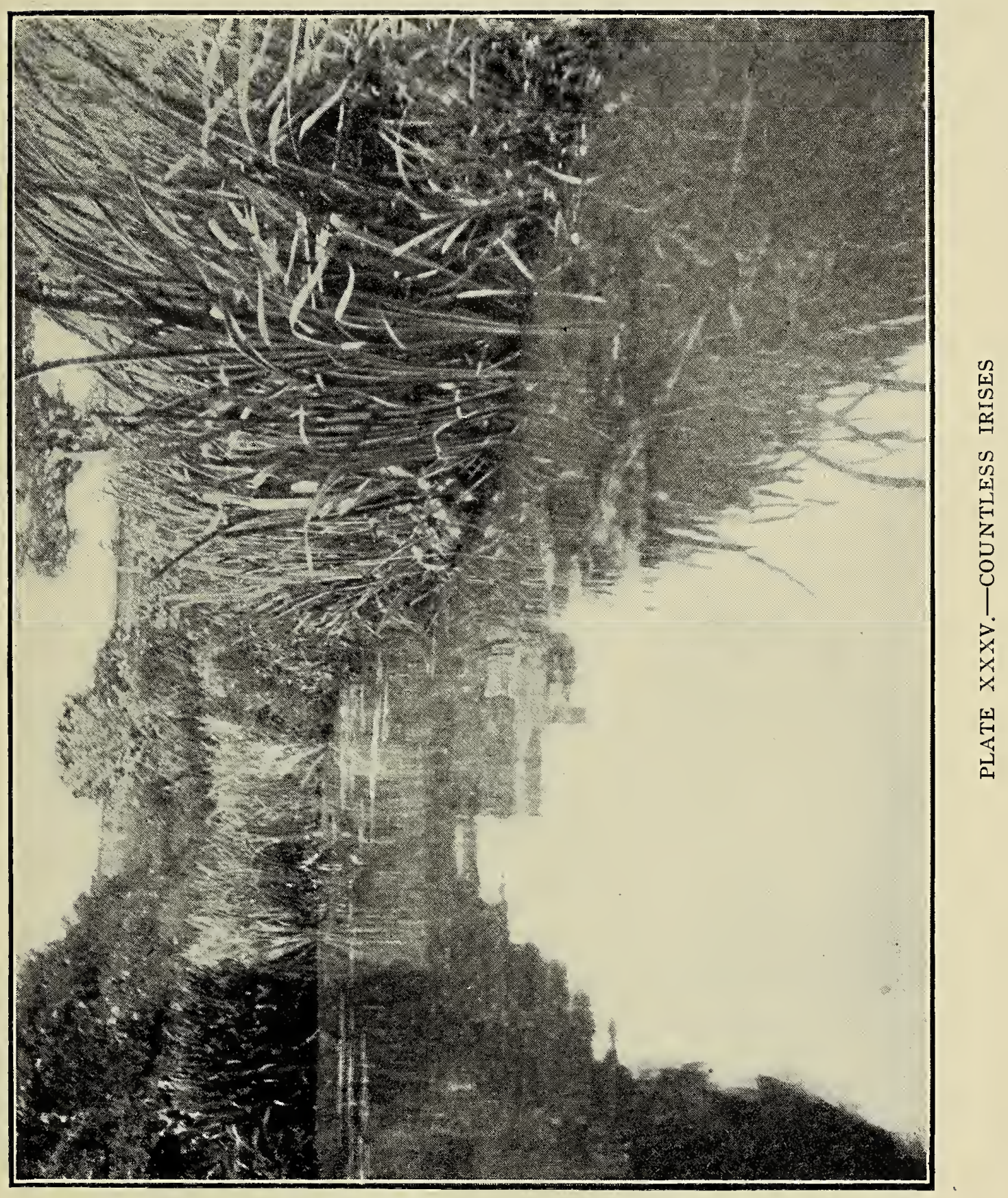



found that myriads of tiny insects, or, in fact, birdlice, were crawling up and down the side of the house, and had even extended their walk along the hammock. They all came from the spongy, mosslike nest of the phobe-birds. For them, the day at once became one of woe. Mrs. Keith would not tolerate having their nest under the roof another minute. She insisted that the young ones be turned out to take care care of themselves, and the nest burned. Mrs. Keith never loses time when she makes up her mind to do a thing. Therefore, she would not wait for Joseph's return, but herself poked down the nest, dropped the fledglings out on the lawn, and then turned the hose on the side of the house.

There was no end of alarm and crying among the parent birds. They had watched Mrs. Keith bring the step-ladder out on to the veranda, and, from then on, they never stopped their lamentations. Fortunately, the young birds appeared quite strong when dispossessed. They flapped their wings as though they knew the time had come for them to practise flying. Often they tumbled over when they tried to walk, but one of the older birds would give them a push in the way of encouragement. The whole family started across the triangle, and, before Joseph returned, they had nearly reached its moist point. They seemed to have the idea of getting under the shelter of the coppice. I felt sure that the little ones were exceedingly weary; 
yet the vigilant parents would not let them rest until they were housed somewhere far away from Mrs. Keith.

Joseph could hardly realise the disgrace intowhich they had fallen, although Mrs. Keith stated the facts of the case to him very plainly. I was thankful we had no cats, which might find these young birds dainty morsels of food before they had learned to keep themselves well up in the air.

At Nestly Heights, Joseph had beaten both Ben and Harry at tennis, and had been asked the day following to play in a set with Mr. Percy. This he regarded as showing advancement on his part. For the time being, he had much more to say about tennis than about the ousting of the phobe-birds from their home. He seemed not even to have noticed which flowers were blooming particularly well at Nestly Heights. Indeed, throughout the evening he wore the air of a conquering hero. 


\section{CHAPTER XXVII}

\section{EARLY AUGUST DAYS}

$I^{T}$ is August. The annuals that Joseph sowed 1 early are having their main crop of flowers, while many of the perennials have grown tall and important-looking. My monthly roses are blooming a little less freely than they did in July. It may be perhaps that they do not like these sultry days and cool nights. August, happily, is the time to enjoy things in a garden without doing very much work. Joseph has been playing every day lately in the tennis tournament. I believe he is growing to like this sport almost as much as gardening, although he says he has only been playing to let Ben and Harry see that once in a while he can beat them. He has, besides, read much less in "An Ambitious Boy's Garden" than formerly, although this does not surprise me, as I should think he might be able to repeat it from beginning to end.

But, while Joseph has been playing tennis, Timothy has shown great devotion to the garden. $\mathrm{He}$ has weeded it often, and kept the borders trimmed neatly. He is making up his mind, he says, about 
what is to be done here later. Mr. Percy, likewise, is thinking about what we should do this autumn to make our garden beautiful next year. For myself, I like simply to enjoy August without thinking of work for either this autumn or next spring.

At the moist point of our triangle, the cardinalflowers are now well in bloom, and this is enough beauty for one day. Yesterday a turned-out phœbebird sat on the stalk of a flaming red flower, slightly tipped over by the bird's small weight. I think the fledgling had been making an unsuccessful attempt to catch insects in the air, as the mother was near-by, talking to it in a way that sounded like scolding.

In this part of the garden some glorious rosemallows are now blooming. They remind me more of hollyhocks than they do of roses. Mr. Percy gave us their roots and planted them for us himself, some time after he and Joseph had set out the ferns. For a while, we almost forgot them, although I saw that they were growing to be unusually large plants, with leaves of an attractive green. But neither Joseph nor I had any idea of the gorgeous flowers that would burst out in August from their large buds. Some of these flowers are white with a crimson ring at their base, which has given them the name of "crimson-eye." The others are a pure, brilliant pink. Mr. Percy had been watching for the day when they would open, 


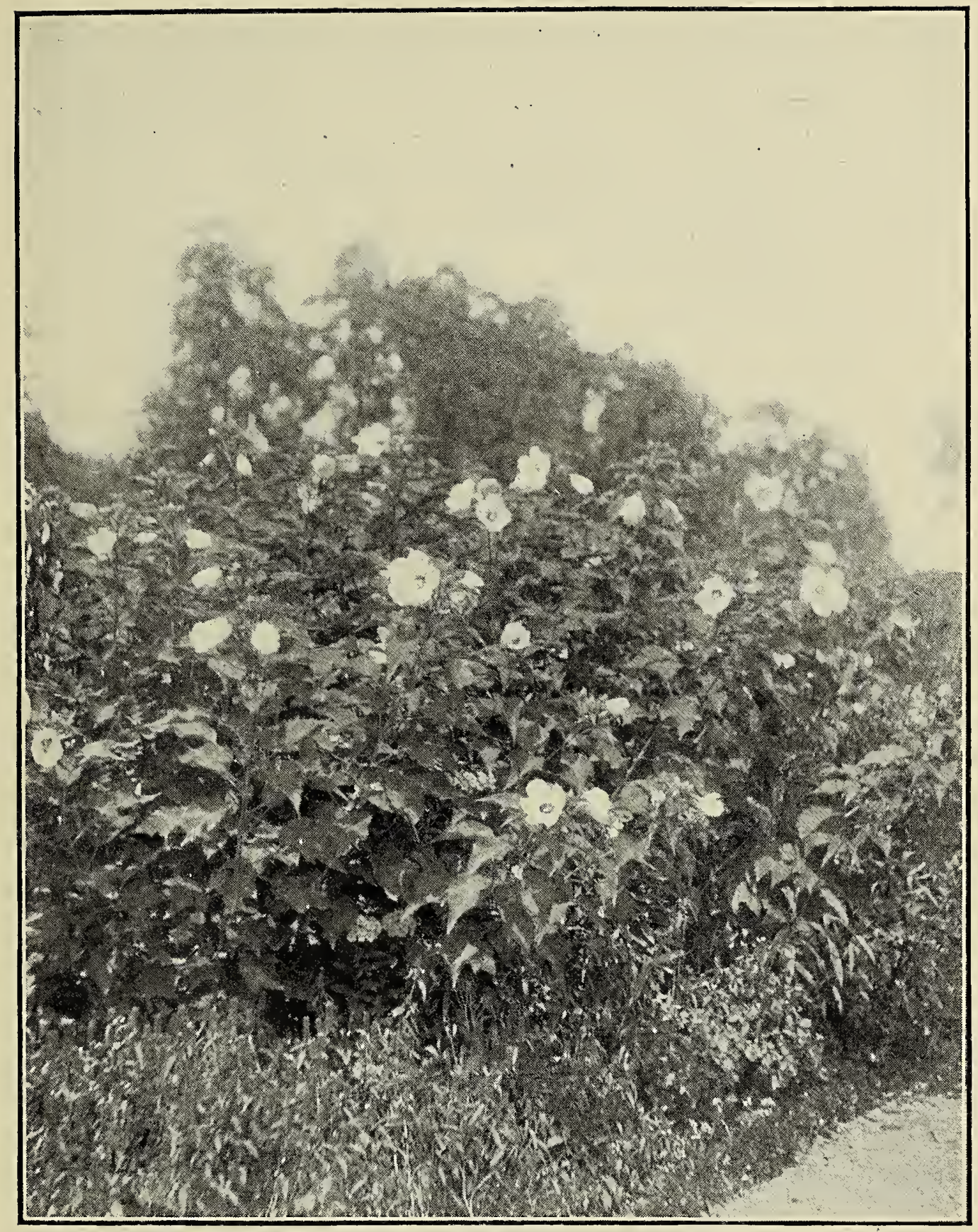

PLATE XXXVI.-ROSE-MALLOWS 

and, had this not happened too early in the morning for any one to be about, I think he would have been here to greet their first unfolding.

"You will have them every year now," he told us, "without further trouble. They are perennials, and very hardy. Besides, they seem to have taken well to this moist, rich soil. You would be surprised, I know," he continued, "if I should tell you that they are wild flowers."

Joseph asked if this were a joke.

"Not at all," Mr. Percy answered. "They are as much wild flowers as hepaticas and springbeauties, and grow in swampy, marsh-like places, instead of in the woods. Sometimes I have found them in such wet meadows that it was impossible to reach them without rubber boots. My father," Mr. Percy went on, "is very proud of the rosemallows at Nestly Heights. He has them set, you know, about the ponds. He praises the gardeners as though they were as responsible for the beauty of the mallows as they are for the blue colour of our most petted hydrangeas. Some day I will take him to a swamp miles from here, where they grow twice as large as with us. Many of them there are eight feet tall."

Joseph glanced at me. He must have been wondering what Mr. Hayden would say when shown some of his favourites thriving in a neglected swamp. The fact that rose-mallows are wild flowers makes Joseph and me like them better than 
ever. We have more confidence in them, feeling that they can never disappoint us.

I picked one of the flowers and-some large leaves to put in water in the house. We wished,to look at it even after the dusk had fallen. But, alas! the leaves very quickly withered, and the flower drooped. Before twilight came, it had lost its attractiveness.

"Next time," Mr. Percy said, "pick large buds just beginning to show colour and put them in water. I believe they will then open and remain fresh."

I tried this the next day, and it was as $\mathrm{Mr}$. Percy anticipated. The flowersythat opened in the house were hardly as large as those that remained on the plants; but still they were not small, and held themselves up firmly for several days. These rose-mallow blossoms are usually as large as, and sometimes larger than, hollyhocks.

Another wild flower that is now blooming in many gardens is called Oswego tea. Miss Wiseman has it at her place in great, important masses, which look very handsome. She told us it was a wild flower that gardeners had found desirable to cultivate; although, as far as she knew, it appeared no different in her garden, where it had been watered and cared for, from in various nooks of the woods. She liked the rich red of the flowers, which harmonised with the foliage of her Japanese maples. 
Oswego tea has been in bloom at Miss Wiseman's since July; but only while speaking about our rose-mallows did Joseph find out that it also was a wildling which had fallen under the eye of gardeners. It belongs to the mint family, and increases almost as rapidly as the little, common mint, which many people transplant from wayside brooks. In fact, the foliage of Oswego tea has something of the same spicy fragrance.

I asked Joseph if he expected to plant it at the Six Spruces next season.

He answered that perhaps he would put some of it near the tall brakes, which he wishes to have look as if they were just stepping out of the coppice.

I felt sure, then, that Joseph had been pleased with the plant, and already planned to have it in our garden. It ought to feel at home among our other wild flowers.

The morning-glory vine is still bearing flowers, and Joseph and I are in love with it, despite the alarm cry that, if we sow it another year among our perennial vines, it will rise up and choke them to death.

"That is a dreadful tale," Joseph commented, "to hear so often about anything so lovely."

Joseph loves morning-glories, but his dislike to petunias is very great. He does not wish one of them at the Six Spruces.

"Do you not think the shape of a morning-glory 
and that of a single petunia are much alike?" I asked him, for fun.

"Yes," he answered; "but, aside from the shape, they are quite different."

"Some of the petunias at Miss Wiseman's," I said, "are beautifully coloured. She has them of lavender and pink as delicate as our morningglories."

"It is not their colour," Joseph replied, "that makes them so ugly."

"What is it, then?" I asked.

"It is because they are themselves."

"They are very easy to raise," I persisted. "People just sow them in the spring and then let them grow."

"I know," Joseph assented. "They are annuals."

"Nearly every one about here has them," I said.

"Do you like them?" Joseph asked suddenly.

"Oh, no," I confessed, and added that I was just trying to find out why he disliked them so much.

"Well, it is their smell I do not like," he said at length, "and their sticky feeling."

So, after all, Joseph had his reason for disliking petunias.

When Queenie Perth came to see us last she wore a hat covered with petunia flowers, on which were perched three yellow butterflies. She had taken the artificial flowers off her hat, she told us, because the butterflies had found out that they were 


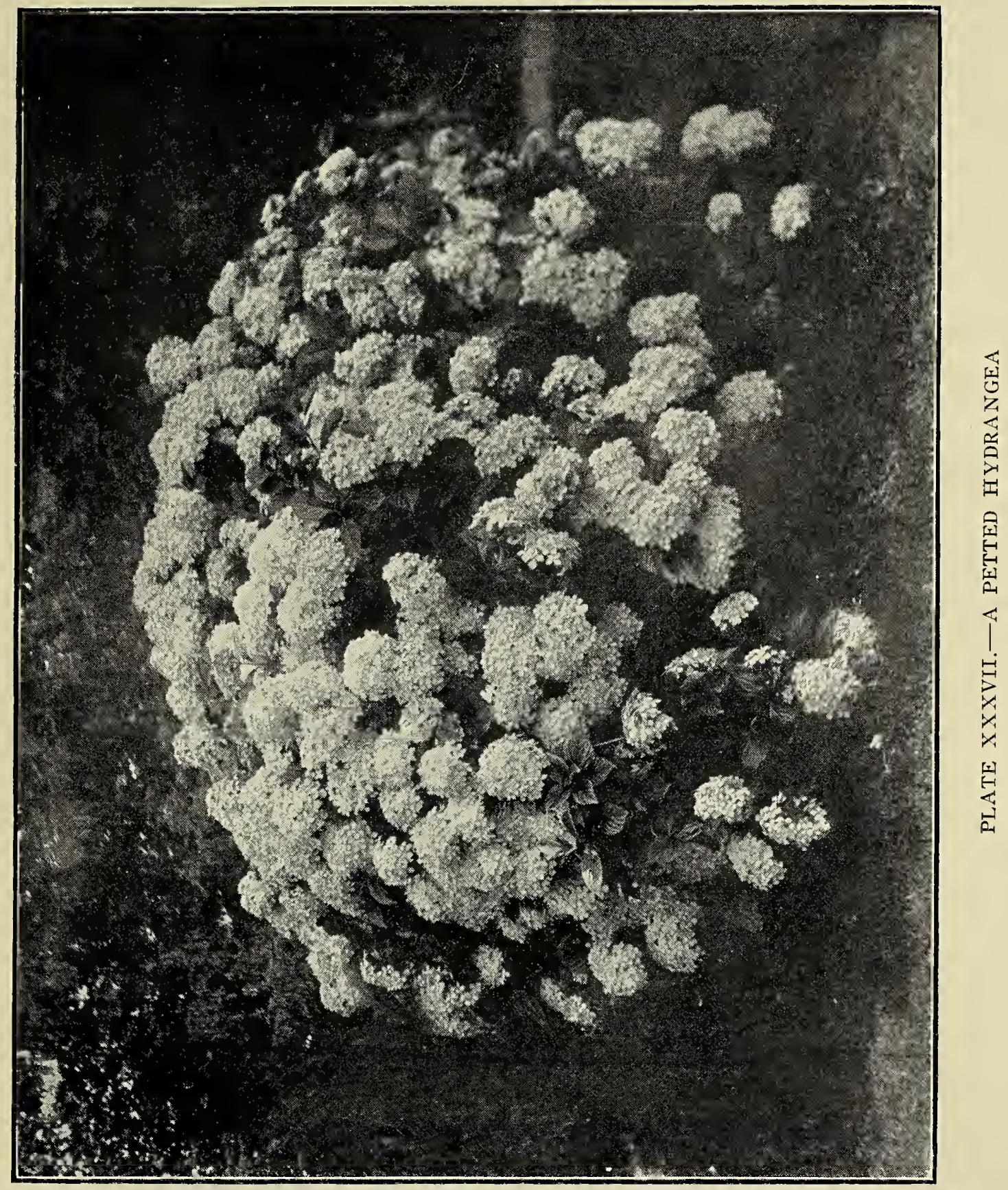



not real. Her Auntie had given her permission to pick as many petunias as she wished.

"You know they do not matter," she said with something of Joseph's contempt for them. "I do not bother to pick them. I cut them with the sickle."

We began to understand why it was that Queenie had sometimes such large bunches of golden glow, phloxes and petunias about her. The portulaca flowers, however, that are blooming in her own garden she never picks. Occasionally we see her gathering their tiny seeds, which are like grains of silver. Wherever there was space, Queenie must have sown them in her garden. She seems to admire these small flowers of red, white and purple almost as much as do the butterflies. It was from her that Joseph learned about them, and no doubt he will sow some at the Six Spruces when March or April returns, and the farmers believe the frost has slipped out of the ground.

One of the young catbirds raised in the smoketree has met with a tragic death. It was killed on the triangle by a hideous, yellow cat which we had never seen before in this neighbourhood. We did not know where the cat came from, or what attracted it. Perhaps it heard the young bird trying to imitate its cry.

When Mrs. Keith reached the triangle, the yellow creature had the bird in its mouth, and was making for the wall as fast as it could. Mrs. 
Keith struck it with a broom she had in her hand, at which it dropped the poor bird and sprang over the wall for its life. The bird was still warm, and for an instant Mrs. Keith thought she could feel its heart beating.

"Never again will I allow a cat to come on this place," she said later to Joseph and me. "Your Aunt Amanda never had one here."

"But the cat did not ask your permission to come," Joseph replied, "and probably it never will."

Then we all thought it was a great pity Mrs. Keith had not struck it harder with the broom. 


\section{CHAPTER XXVIII}

\section{LITTLE JOSEPH WINS THE TOURNAMENT}

J OSEPH has just won the tennis tournament, playing against several boys that were considerably larger than he. In the beginning, hardly any one thought he had a show of winning, Ben and Harry least of all. He kept on, however, steadily holding his own, until in the end there was no one left whom he had not beaten.

When it was over, every one shook his hand and said how well he had played. He was more embarrassed at this than he had been uneasy over the last set, which had been so excitingly close.

"So the honours are yours, Master Joseph," Miss Wiseman said; and Mr. Hayden shook his hand as he does when he is most like the merry west wind.

"If I were a few years younger," he said, "I would tackle you myself. Those boys of mine are too idle to play against such muscle." With this, he gave Joseph's arm a squeeze.

$\mathrm{Mr}$. Percy did not play in the tournament. $\mathrm{He}$ told Joseph that he was delighted he had won, and 
that it was just what he had expected. Queenie pinned a flower in Joseph's buttonhole, and said that she would give him one of her tamed butterflies. We had no idea until then that Queenie had been doing such a funny thing as taming butterflies, and thought it must be rather uncertain work.

Mrs. Keith, who had gone to see the finals of the tournament, desired, when it was over, to take Joseph home at once. As she expressed it, she feared he would have his head turned. But when we were again at the Six Spruces with Little Joseph, it was as though nothing wonderful had happened. $\mathrm{He}$ took up "An Ambitious Boy's Garden" and began to read it most seriously. Later he said to me: "Next year we must not forget to have sweetwilliams. We skipped them this year, because there was so much else to think about, and so many other plants for which to spend money."

I was delighted to hear Joseph talking again in his sensible way about the garden. When I had seen him on the tennis court giving back-handed strokes, while every one clapped loudly, my heart for a moment stood still-not because I thought he would miss the ball, but because I feared that, like Ben and Harry, he would grow to love tennis better than gardening. Now I know this fear was foolish. I believe Joseph will continue to care for the garden above all else.

Miss Wiseman sent him such a beautiful bunch of gladioli that he promptly decided to have them 
in the garden next year, even though they are a bit more troublesome than plain annuals and hardy perennials.

I ran to the rose fan, and there three Kaiserin Augusta Victorias, white and waxen, were ready for me to cut and put in the silver cup that Joseph had brought home from the tournament.

"We must take the very best care of that cup," he said. "You know it is not mine to keep unless I win the tournament for two more years in succession."

I said we could do no better than to let it hold such lovely roses. Joseph was not convinced. I saw him look at me dubiously while I was putting in the water.

The possibility of burglars breaking into the Six Spruces and taking the cup away next troubled Joseph, although before this he had never thought of their coming. He wondered if we had not better carry the cup upstairs every night, and put it where Aunt Amanda kept her silver.

"You had better play with it as much as possible while you have it," Mrs. Keith advised. "Likely enough, it will go home with some other boy next year."

Joseph looked long at the cup, then turned it around and ran his fingers over its smooth surface. I believe he was making up his mind to keep it forever.

During the days following the tournament, Jo- 
seph attended strictly to the garden. He weeded, sprayed and cultivated the soil around the base of many plants. He repaired some of his tools that had become broken during the summer, and generally tidied things up a bit. He also set himself about cutting worms' nests out of a tree at the edge of the wood-border.

At Nestly Heights they have a pair of clippingshears to do this work which are fastened at the end of a very long handle. A man can stand on the ground and yet reach with this tool the high branches of a tree. But Joseph has no such shears, nor do I believe he would have used them if he had. In the trees, he is like a squirrel. He finds delight in crawling out to the tip-ends of the branches where the worms have made their nests. I have seen him lying flat down on a branch while he pulled his pruning-shears from his pocket. Again, I have watched him sit in a position just like a squirrel cracking nuts. 'These worms' nests once unfastened, Joseph makes a bonfire of them, as the surest way to keep the insects from crawling to other parts of the garden. This pleases him almost as much as clipping the nests from the trees. It gives him an all-over-good feeling, as though he had made way with something very wicked.

Although Joseph sowed no asters this May, we are not without them in our garden. In June, when Miss Wiseman was transplanting the aster seedlings that had come up in her bed, she gave 
us quite a number to set out for ourselves. We planted some of them in front of the phloxes, thinking they would be gone before the asters began to bloom. In this we were mistaken. The phloxes are still showing bright heads of bloom, while the asters have flowered earlier than we expected. Now, in mid-August, these asters, with the wonderful gladioli, are the most noticeable flowers in Miss Wiseman's garden.

I am gathering our asters for bouquets in the house. They come in many gay colours, and remain fresh almost a week. We have, besides, some late-flowering, branching ones which later on we expect to bear snow-white blooms. At present, I can see only their snug, shining buds.

The asters are favourites with a miserable little creature called the blue-aphis, which eats the under part of their roots. Joseph has worked in wood ashes about their base as a cure for the disease the blue-aphis produces, and he sprayed them with tobacco-water just before the buds appeared. Throughout the dry weather, also, they have been kept well watered.

Other lasting flowers lovelier to me than the asters are our ten-weeks stocks. Alre'ady I have related how pleased we were with the white ones. Next year we will sow no other colours, except, perchance, a number of yellow ones. Somehow, we have an especial affection for the flowers that we selected from the catalogues before even a leaf 


\section{4}

\section{JOSEPH WINS TOURNAMENT}

appeared on the trees. Many times Joseph has said to me: "We were lucky in choosing those ten-weeks stocks."

At Nestly Heights these flowers are quite ignored by the gardeners. I was rather glad of this, for it enabled us to send Mrs. Hayden a bouquet of something she had not herself.

The phloxes have been the most triumphant flowers this August. They have amazed us by bearing many heads of bloom, in various colours. Usually I do not like magenta flowers, but phloxes of this colour are quite lovely. I have even seen them mingled with others of a strange, pinky brick shade, and yet they appeared to harmonise. If, however, I had seen these. two colours side by side in other flowers, or in a lady's gown, they would perhaps have distressed me.

Joseph thinks the mist we have had so much of this August may have blended the phloxes' colours together. He says they are very grateful plants, and that, once well started, they need but little care, and will send out numbers of bright flowers. Our garden is aglow with them. Chipping-birds and sparrows trip in and out among them, and some fat robins that have not been long out of the nest never fly far away.

These robins remind me of a strange story told us by Queenie Perth, one which we have found to be quite true. Last week she came here and asked Joseph why he had not been to see her Auntie's 


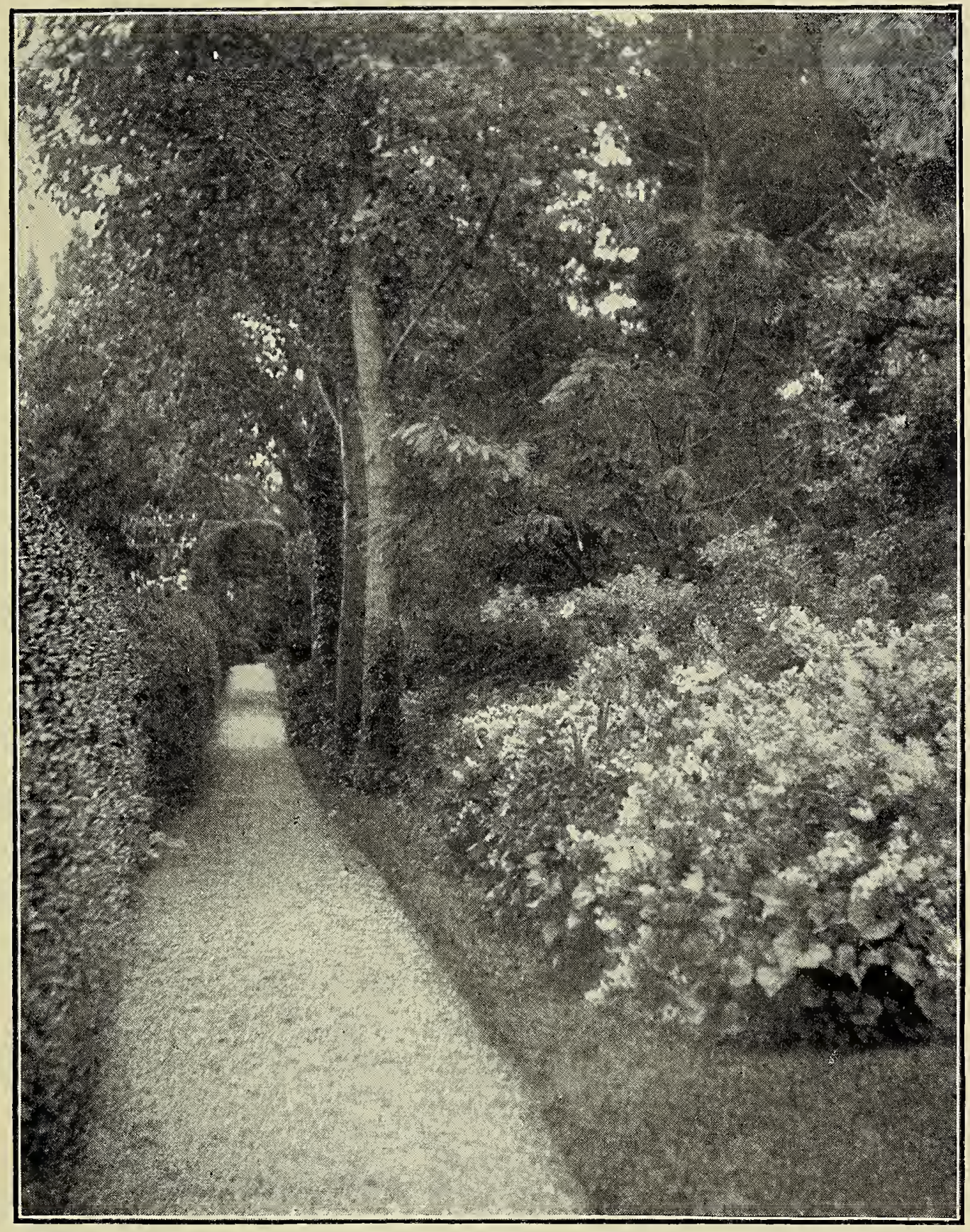

PLATE XXXVIII.-“'MISS WISEMAN'S NARROW PATH WITH THE HEDGE ON ONE SIDE AND THE FLOWERING SHRUBS ON THE OTHER" 

white robin. "You will know it," she said, "by its red breast, although its other feathers are white."

Joseph paid little attention, thinking Queenie was teasing. He would not even mention the words "white robin" for fear of being caught in a trap. Then one day Miss Wiseman said to me: "It is too bad you did not step in earlier. The white robin has just been about."

I asked if it were really true that there was a white robin in the world.

"Quite true," Miss Wiseman answered, "and he lives here on my place. We have all seen him many times. Last year," she told me further, "we had a robin here with a white feather in his tail. How he happened to have this one white feather, I do not know ; but it gave him quite an air of distinction. Perhaps he stayed around here all winter in the evergreen plants, but I never saw him after November, when the hardy chrysanthemums were blooming. One day this summer, I think in late June, this entirely white robin came hopping over my lawn. His breast is brick red, and in every way he is like other robins except for his white feathers. Percy Hayden calls him an albino," Miss Wiseman continued. "I call him a freak."

Later, when we walked along Miss Wiseman's narrow path with the privet hedge on one side and the flowering shrubs on the other, I myself saw the white robin. He was picking up grubs among the 


\section{JOSEPH WINS TOURNAMENT}

shrubbery, not in the least disturbed by our nearness. I should have known him for a robin anywhere, in spite of his whiteness.

I asked Miss Wiseman if she thought him the same bird that she saw last year with the one white feather.

"It is possible," she answered, "and there may be something wrong with the colouring matter of his feathers. Again, I have thought that the one of last year was the parent of this bird. At least, there is no doubt about his being. white. You must ask Master Joseph to come here and tell us the reason." 


\section{CHAPTER XXIX}

\section{THE RETURN HOME}

EOR nearly a fortnight, Joseph and I had been away from the Six Spruces, staying in the place where we lived before coming to Nestly. We used to think it a pretty place when our home was there; but now everything seems changed. We could scarcely believe we had lived happily there for so long. Of course, then we had not the Six Spruces to care for, and we knew nothing at all about the real joy of gardening.

We were so glad to get back last evening! As we drove through the gate, we thought the spruces were waving a welcome. Mrs. Keith said it had not seemed like living while we had been away, and even the birds chirped and acted as if they were glad to see us again. Mr. Percy met us at the station, and drove with us to the house. In every room there were flowers.

"Now do not think," said Mrs. Keith, "that I have ventured to pick them all from the garden. They came from Miss Wiseman and Nestly Heights." 
It had been Joseph's wish to return home at dusk. I think he dreaded seeing the garden first under the full light of the sun. Then nothing can be hidden. At dusk, however, as we glanced over the triangle, all appeared much as when we went away. We were able to sleep in peace. Indeed, little had changed at the Six Spruces. The flowers and messages from our neighbours made it seem gay and good to be home again. Mr. Percy stayed with us for dinner this first day of our return, and then went quickly away. I think he noticed that the "sandman" was already troubling Joseph's eyelids. We both slept early and well.

I do not know at what hour in the morning Joseph awoke. It must have been fairly early, as, when I was in the garden at eight o'clock, he was there looking as if he had been pulling weeds for hours. The dew was still on the grass, the scent of early morning was over everything, and the birds had not finished their chatterings. The garden never looked more lovely, yet it was changed. I saw this clearly. I do not mean that it was apparent because a few weeds had taken advantage of Joseph's absence, or because the bugs had eaten many rose-leaves. I saw it, perhaps, because $\mathrm{Au}$ gust had passed on to September.

Almost all the plants that we had left in bloom were still sending out flowers. The nasturtiums, both dwarf and climbing, appeared to be outdoing themselves, the phloxes were merrily showing their 
colours, and asters were coming into fuller bloom. Neither mignonette nor heliotrope had thought of drooping; roses were blooming in the fan. Cardinal-flowers and rose-mallows shone from the moist point of the triangle. Still, the garden had a different appearance from what it had had in August.

"It must be because the hydrangeas are in bloom," Joseph said when I spoke with him about it.

"Oh, but I have already thought of them," I said. "I was surprised to see how well they looked near the phloxes, almost touching the golden glows as they do." It was. not because they were blooming that the garden was different.

"Do you think things are beginning to have a tired look?" Joseph asked.

"No, indeed," I answered. "Timothy has kept everything wonderfully fresh."

"Then the change must be in the air that has breathed upon the flowers," Joseph said.

This perhaps was true. It had ripened some of the leaves of the Virginia creeper on the wall, where already they shone crimson or red, while here and there I noticed yellow or golden leaves melting into brown. Surely, the finger of autumn had touched our garden.

"It cannot always be summer," Joseph reminded me. "I suppose autumn has come. I shall soon have to go to school." 
This thought was not pleasant. Joseph away nearly all day at school, and Mr. Percy back at college! The garden showed wisdom in getting ready to die when those who attended it should be away.

When we came to Nestly, last March, it was too late in the season for Joseph to begin going to school. He had, therefore, been free to make, and to work in, the garden. His long holiday had been one of sheer delight, with hardly an idle moment. In another month I shall be left alone with the fading flowers. When Mrs. Keith called to us, I was feeling rather desolate.

We had not finished breakfast when Queenie Perth ran in. Her arms were laden with asters, with which she pelted Joseph and me, throwing the remainder into Mrs. Keith's lap, to save herself from a reproof about making the room untidy.

"I am to stay," she said, "until Auntie comes for me, which perhaps will be never, because Mr. Bradley is talking with her."

We had before heard Queenie lament that she had to wait very long for Miss Wiseman whenever she began talking with her gardener.

"You went away," Queenie told Joseph, "before the butterfly I promised you was tame, and, when it grew tame, it died."

"Poor creature!" Joseph exclaimed. "You must have led it an awful life."

"You are mistaken," Queenie said solemnly. "It 


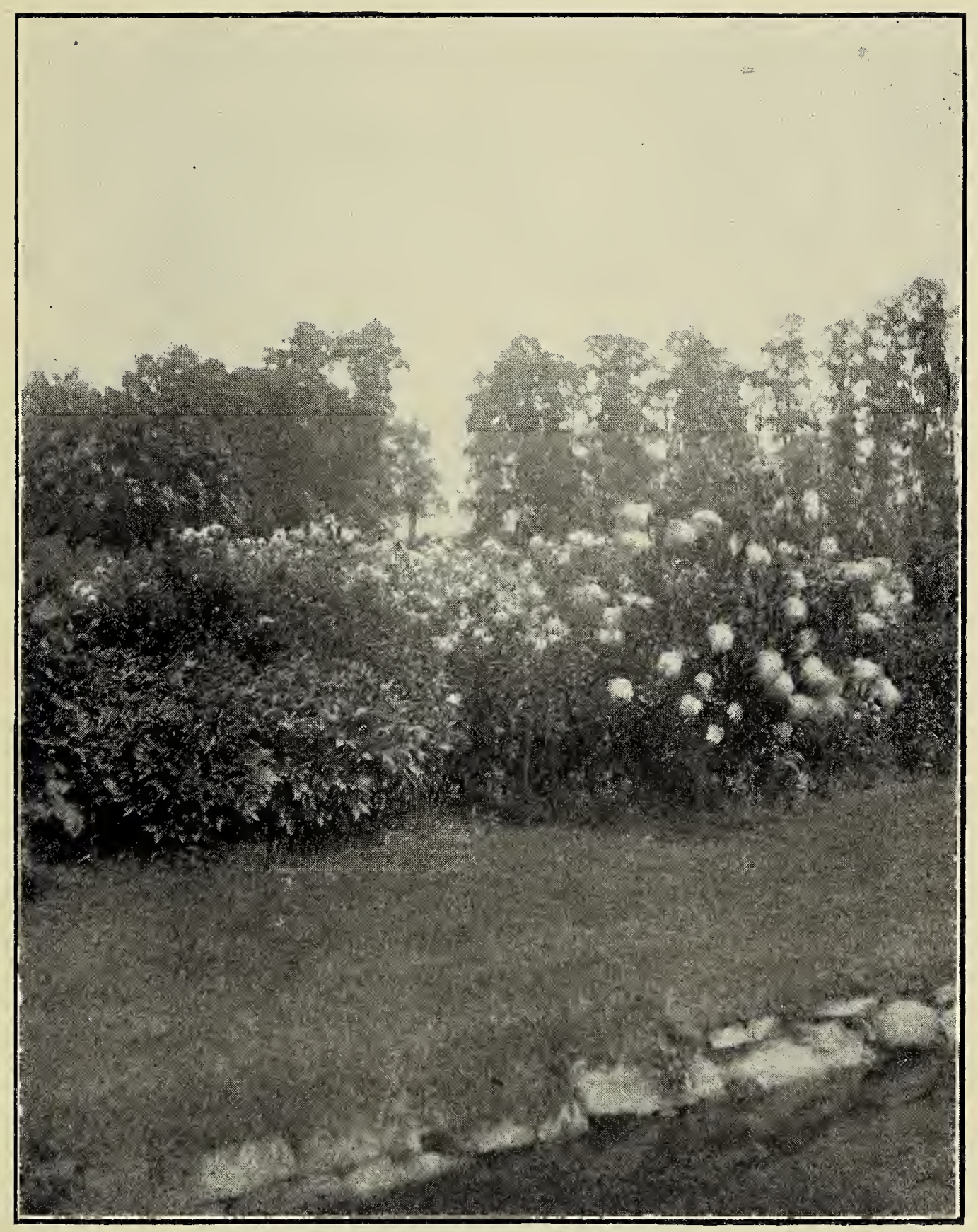

PLATE XXXIX.-HYDRANGEAS AND PHLOXES 

lived in my room, where there are many flowers and two lumps of sugar. There was no wind there to toss it about, and the rain could not get in to wet its wings. It liked living there very much. It often sat on my head and on my hands. It was not a bit afraid of me."

"Then why did it die?" Joseph asked.

"Because it was stupid," Queenie answered. "It got into the mucilage-pot."

This, indeed, was a more humiliating death for the tame butterfly than either Joseph or I had anticipated. When we asked her if she intended to tame another one, she said: "No, anyway not until I have finished reading a beautiful story about some butterflies that in the winter fly off to the South to live."

"Do you mean that butterflies migrate like birds ?" Joseph asked.

Queenie nodded her head. "Some of them do," she added; "not all. Jack Frost kills many butterflies," and she waved her hands around as though the air was full of them.

"Which ones migrate?" Joseph asked, seeking information.

"The milkweed butterflies," Queenie answered promptly. "They are the only ones that fly down to North or South Carolina, or some warm State of the Gulf, to spend the winter. Hundreds and hundreds of them go together. I think their wings must be tired by the time they get there." 
From Queenie's vaice we were sure that she knew quite well what she was relating. Often she is mischievous, but, when serious, she is much more accurate than most little girls.

We went back to the garden to wait for Miss Wiseman and to look more closely at the hydrangeas. Besides small ones in the garden, we have also the large tree-like hydrangeas which Miss Wiseman gave us with the other shrubs. They follow the lower curve of the circle in front of the house, and are also in bloom. The small ones we bought ourselves, to fill up some of the bare places at the back of certain flowers. There is something very generous about these large bunches of hydrangeas. Perhaps they wish to be lavish with their bloom because the autumn will so soon rob us of other things.

"It is truly hydrangea-time," Miss Wiseman said when she found us in the garden. "I hardly know what I should do without these shrubs at this season of the year."

We showed her the ones she had given us in front of the house. Although she had noticed their beauty as she drove in the gate, she had not remembered that it was she who sent them. Miss Wiseman gives away a great many things, but she never torments people by pointing them out as her gifts. Mr. Percy does not do this, either. He even asks Joseph about the rose-mallows, the ferns and other things that he has himself planted for us, as if he 
had done nothing towards their welfare. We have one neighbour, however, whose name I will not mention, who always spies out and praises the plants he has given us. One day he said to Joseph: "That pansy I gave you is the best-looking flower in the garden."

This somehow made Joseph wish he had never given him the pansy.

Besides the hydrangeas, the clematis paniculata leaning on our wall has opened many of its creamwhite flowers for September. They scent the air with their fragrance, and are soft and fleecy to look upon. Although our vine is young and just beginning to show what it can do, its growth has been remarkable for this one year. At Nestly Heights the clematis vines form arbours, climb over trellises, and appear like heavy clouds of bloom. Beside many humble cottages in Nestly this vine is now turning everything to beauty and fragrance. It seems to be the bride of September, as the spirea was the bride of June.

"How fortunate it is," I said to Joseph one day, "that all flowers do not open in the same month, last in bloom the same length of time, and then perish together. Nature has arranged her flowers so that they are never monotonous. They give pleasure, give surprises and cause deep regret when they are no more."

In early spring came the little shy blossoms, barely daring to open for fear of the cold. Then with 
each month the flowers grew more assured and confident, until, in June, it seemed as if they knew something about their own beauty. Later in the summer, they became bold in gorgeousness, while now in September they are toning down again and wearing an air more modest, more like that of spring. This may be caused by fear-the fear of being caught by Jack Frost.

When Joseph and I were returning to the Six Spruces, we looked out of the train windows most of the way. We passed fields of goldenrod, and, when we ran through narrow, secluded places, wild asters hemmed us in on both sides. Their colours were white, lilac and purple. These, I thought, were the right colours for autumn, looking well with the distant rods of gold and the leaves overhead tipped with browns, crimson and yellow.

But nowhere in all this medley of wild autumn flowers did I see pink, the pink of the dogwood, the azaleas, and Aunt Amanda's blush-rose. This is the colour of spring and early summer. I was glad that it did not occur through these autumn fields. It would have appeared too fragile against the masses of gold and purple.

While I was thinking about the colours of the seasons, Miss Wiseman was saying with some emphasis:

"You come to me, Master Joseph, and read me a chapter or two from that note-book of yours before 


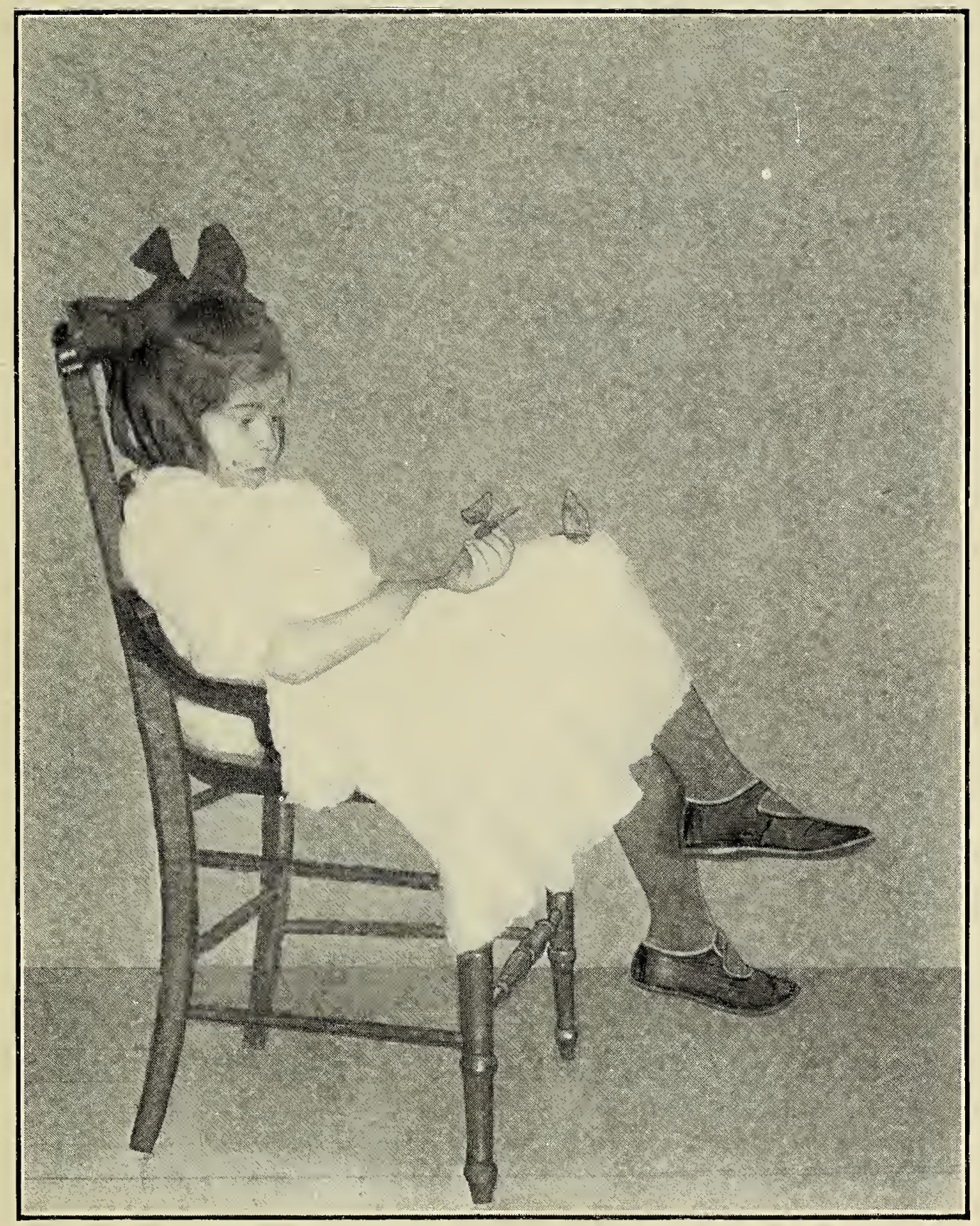

PLATE XL.—THE TAMED BUTTERFLY 



\section{THE RETURN HOME 235}

buying any bulbs or plants to set out here this autumn."

Together then they walked out of my hearing. Queenie and I were left alone to talk about butterflies and the white robin. 


\section{CHAPTER XXX}

\section{SEPTEMBER DAYS}

[ ONG ago, in the spring, Joseph decided to much-slandered morning-glories as annual vines against the wall. He wished to have perennial vines, that they might take permanent hold and not require to be resown every season. In this decision he was wise. Our wall has been fairly well covered this first season, and has shown its possibilities for beauty when the vines are older.

The crimson ramblers did not begin to bloom until July, after the principal flowering of the rose fan was over. I like these crimson ramblers better than those of other colours. At Nestly Heights there are some famous yellow ramblers, but Joseph believes they are not as hardy as the crimson ones.

We were fortunate in choosing the honeysuckles and the clematis paniculata to send out strong wafts of fragrance. The nasturtiums are still blooming as freely as they did earlier in the season. Though they are annuals, I hope Joseph will always sow them somewhere about the garden. I have found 236 
that they do just what is expected of them. They grow and bloom, always looking cheery and fresh. So far, I have not noticed that insects molest them especially; and, except that we had to: show them once in a while the direction in which we wished them to climb, they have required little care.

In September one begins to think as much about the foliage of plants as about their flowers. For this reason, we can never be too glad Mr. Percy helped plant our Virginia creepers. Now their leaves are more brilliantly red and crimson each day, while among them gleam many bunches of small, blue berries. They are the colour of Concord grapes, with a soft, mist-like down over them. The vines we transplanted must have been quite old, for they have grown as though wise in the way of it. The Virginia creepers, bought from the nursery, that Miss Wiseman set out last spring, have made much less growth.

"If you put any more vines on that wall," $\mathrm{Mr}$. Hayden said to me, "my boy will have to go around by the gate."

I replied that Mr. Percy always came in that way.

"Well," he said, "it is a stupid thing to do, when such a wall as that divides the two places. In my day a young man would have scaled any wall rather than quietly walk in at the front gate."

For some reason Mr. Hayden thinks it very romantic to climb over walls. 
Now that September has come, Joseph and I notice that our garden is ripening. It reminds me of an apple blossom that has unfolded and dropped its petals, that the fruit may form; and which finally has grown larger and riper, until it also falls to the ground. Many of our flowers' petals have fallen, while their places are taken by brown seedpods, varied in shape and eager to scatter their holdings over the ground.

In cases where Joseph has not cut off the stalks to keep the plants from going to seed, the birds have found them out and are now having a high feast. Joseph has had to be lively himself to collect as many seeds as he wished to put by for drying and sowing. But, perhaps, because we give the birds this autumn festival, they will wish to return to us next year.

To-day I was surprised to see Joseph with a large package of seeds, dropping them awkwardly and rather carelessly over the ground. This he was doing near the spot where the Shirley poppies had been so enchanting. I had already noticed that he and Timothy had been busy there working over the soil.

"What are you sowing?" I asked.

"Shirley poppies," he answered. "You said you could never have too many of them."

"But before, you sowed them in the spring."

"We can have them earlier next year by putting in the seeds now," Joseph replied. "Miss Wise- 


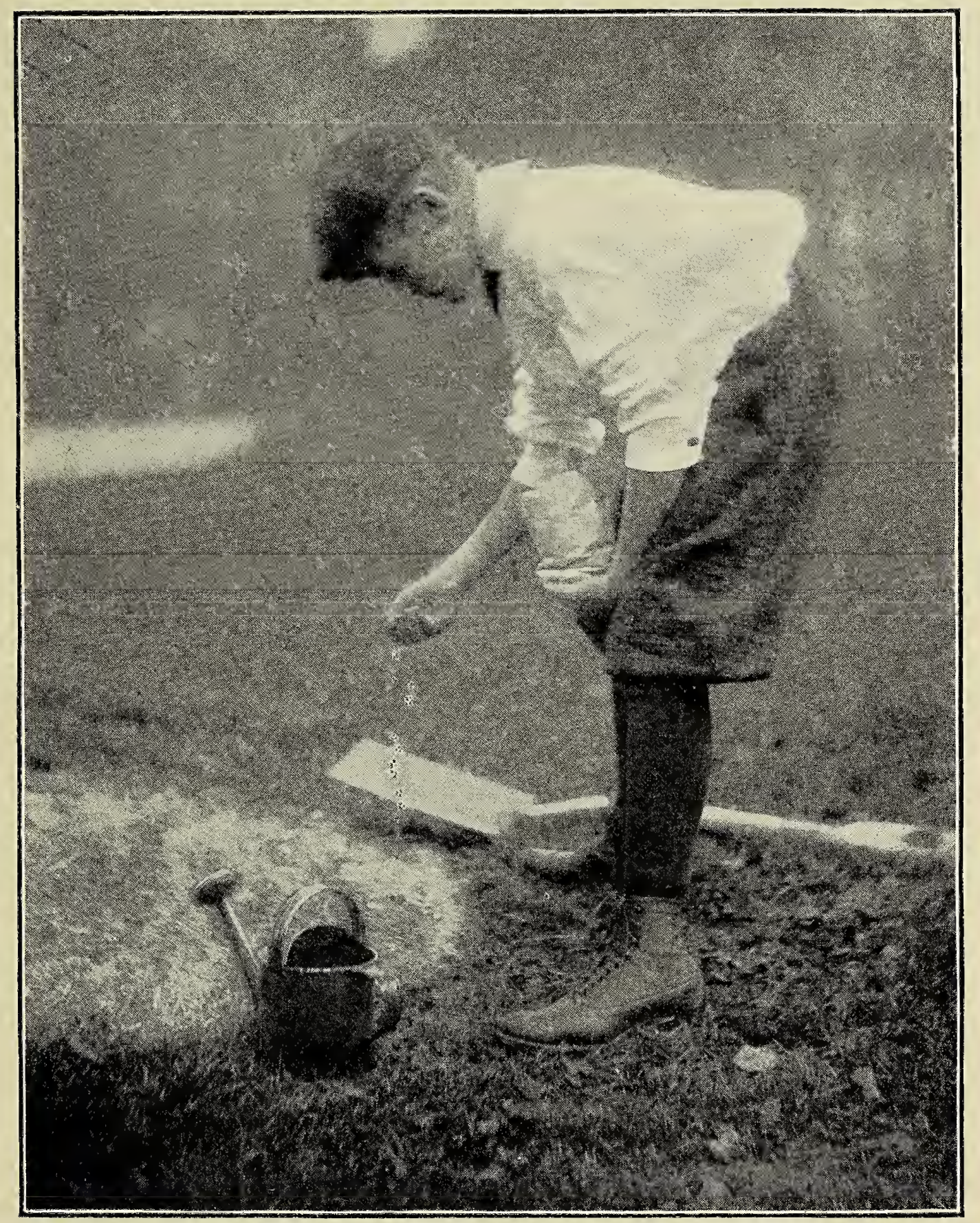

PLATE XLI_ "JOSEPH WITE A LARGE PACKAGE OF SEEDS DROPPING THEM AWKWARDLY OVER THE GROUND" 

man says that these probably will be well sprouted before frost comes, and therefore ready to bloom at least three weeks sooner than we had them this season."

"Three weeks is nearly a month," I reminded him, wondering then if Joseph had found a way to cause these July flowers to open in June.

In our garden at this moment the larkspurs were having a second blooming, rather scattered and indifferent in comparison with the showing they had made much earlier. The phloxes were still gay, and a few of the monthly roses of the fan were as lovely as ever. Mignonette still bloomed, delighting in its cool, shady place, while here and there a rose-mallow was to be seen. The heliotrope-bed held many flowers. Before we owned a garden I had thought this a delicate flower, living mostly in conservatories. It now seems to me almost as hardy for beds and borders as crimson geraniums.

So far, the asters in our garden have not succumbed to the horrid creatures that eat their roots; perhaps because Joseph has been so vigilant with wood ashes. The cosmos look as though they cared not a bit that the season is waning. Yet, when we come directly from Miss Wiseman's, our triangle has a meagre look. This is because it is dahlia month in her garden, and Miss Wiseman herself is a specialist in these flowers. They are blooming now in such numbers that no other flowers except the great, toppling heads of white hy- 
drangeas are to be seen. They appear in every bed and border, they raise themselves from hidden places, and the vases in the house are full of them.

These dahlias of Miss Wiseman are indeed wonderful to look upon. They are not like the rigid, prim flowers that Joseph and I called dahlias before we came to live at the Six Spruces. There are both single and double ones, the latter looking like rosettes, with their texture as soft as velvet. I think the dahlias of a crimson so deep that it is almost purple are the most beautiful, although there are yellow ones that are nearly as lovely.

"I can scarcely realise that you have not a dahlia in your garden," Miss Wiseman said to me. "In September they are my joy and glory. With them I shall beat Mr. Hayden at the show this year."

Miss Wiseman was radiant. I could see that this meant a great deal to her.

"Perhaps Joseph thought dahlias were troublesome," I said. I remembered that their roots have to be taken up and stored over the winter. They will not live in the ground, as do hardy perennials.

"Trouble!" exclaimed Miss Wiseman. "You talk of trouble before such a flower as this," and she lifted the head of a single, velvety beauty which drooped by its own weight.

"It is like a chrysanthemum," she said.

Miss Wiseman was truly excited over her success with dahlias: never before had they done so well in her garden. 
Yet, in relating their wonder and beauty to Joseph, I was somehow not enthusiastic.

"Shall we make the effort and have them next year?" he asked. "It seems that every one expects to see them in a garden in September."

"Not for my pleasure," I answered, and Joseph questioned no further. Perhaps he thought that, despite their astonishing beauty, at the bottom of my heart I had the same feeling about dahlias that he had concerning petunias.

Yet, when Miss Wiseman had asked me if hers were not beautiful, and this and that one an especial beauty, I had answered "Yes." They have a beauty which I can see and admire, but it is one that I do not feel. I could never love dahlias.

"If we have more asters next September, great quantities of them, as many as Miss Wiseman has of dahlias, I think our September garden will be attractive enough," I said to Joseph. For an instant he looked troubled; then he confessed frankly:

"There is a beetle, besides the blue-aphis, that bothers the asters and eats their roots."

"What will you do about it?" I asked, feeling sure that he would overcome it in some way.

"Oh," he said, "it must be taken off by hand. I have mixed some kerosene, gasoline and benzine in a can, and, when I go about, I tap each plant until the beetles fall into the mixture. They die quickly then, you may be sure. Perhaps I shall have to go after them twice a day as long as they 
appear. But this may not be for more than a week or ten days."

Joseph seemed quite resigned to the work before him. I was also enlightened about the queer smell that had permeated our back hall of late. It was there that Little Joseph had made his mixture.

It is his patience and wise persistence in our garden that has made the neighbours say pleasant things about the way we have beautified the Six Spruces. Miss Wiseman has told us that the place is beginning to be talked about in Nestly, and even loved as it was long ago, before our great-aunt grew old and severe in her ways. For, when Aunt Amanda was young, she was fond of people, and the Six Spruces was the gayest place in this part of the country.

Sometimes we have tried to find out from Mrs. Keith why it was that our great-aunt had changed so much that, when she died, she loved no one, and had only the blush-rose bush and the lemon verbena in her garden.

Mrs. Keith invariably answers: "It is a long story, my dears, and this perhaps is not the most proper time to tell it."

She is very particular about doing things at exactly the right time.

For some days a haze has hung over the garden. It has made us notice the flowers less, and think more of the form of the trees, and of the colours that are tipping the still green foliage. The birds 
have a proud look, as though, their families having been raised and well started in life, they had nothing further to concern themselves about until the time arrives to fly southward. How simple is this long journey of theirs! They have no trunks to pack, no affairs to set in order, they even take no road maps. They simply join a gay company of their friends and relatives, and fly off, leaving their farewell notes in the air.

"Our garden will be a much less happy place without the birds," Joseph said this morning. "Timothy Pennell thinks that sometimes the same birds return to the same houses year after year if they have been well suited and left unmolested."

"Surely, we have fulfilled those conditions," I said, and at that moment Joseph looked out the window and saw the yellow cat that had killed the young catbird.

She was flat on the grass, moving along very slowly. Her eyes were terrible. They appeared so sleepy, yet so intense. We looked about to see what she was planning to kill, when suddenly, from where we did not know, Mrs. Keith descended upon her. That time the broom fell across her back with no light stroke, not once but several times. When we saw the last of her yellow tail slipping over the wall, we all felt sure she would not again visit the Six Spruces. 


\section{CHAPTER XXXI}

GETTING READY FOR BULB-PLANTING

SOME flowers have come into our garden this $\int$ September that remind me of the spring days when bloodroot awoke in the woods, and narcissi bloomed in Miss Wiseman's border. These are the Japanese anemones, the bulbs of which Joseph planted in early spring. They are frail and delicate, and look like early flowers. It seems as though they had made a mistake in blooming so near the time of frost. Frost is just a little way behind the flowers of spring, while it approaches these of September. Maybe for this reason, this autumn month reminds me of May. Little Joseph does not see this at all, and says that the fact is not mentioned in "An Ambitious Boy's Garden." Long ago I found out that Joseph sees only what actually exists in a garden, while Queenie and I often are conscious of other things that, though just as real to us, are more difficult to explain.

"Jack Frost will come soon," Queenie said to me lately.

I asked her how she knew. 


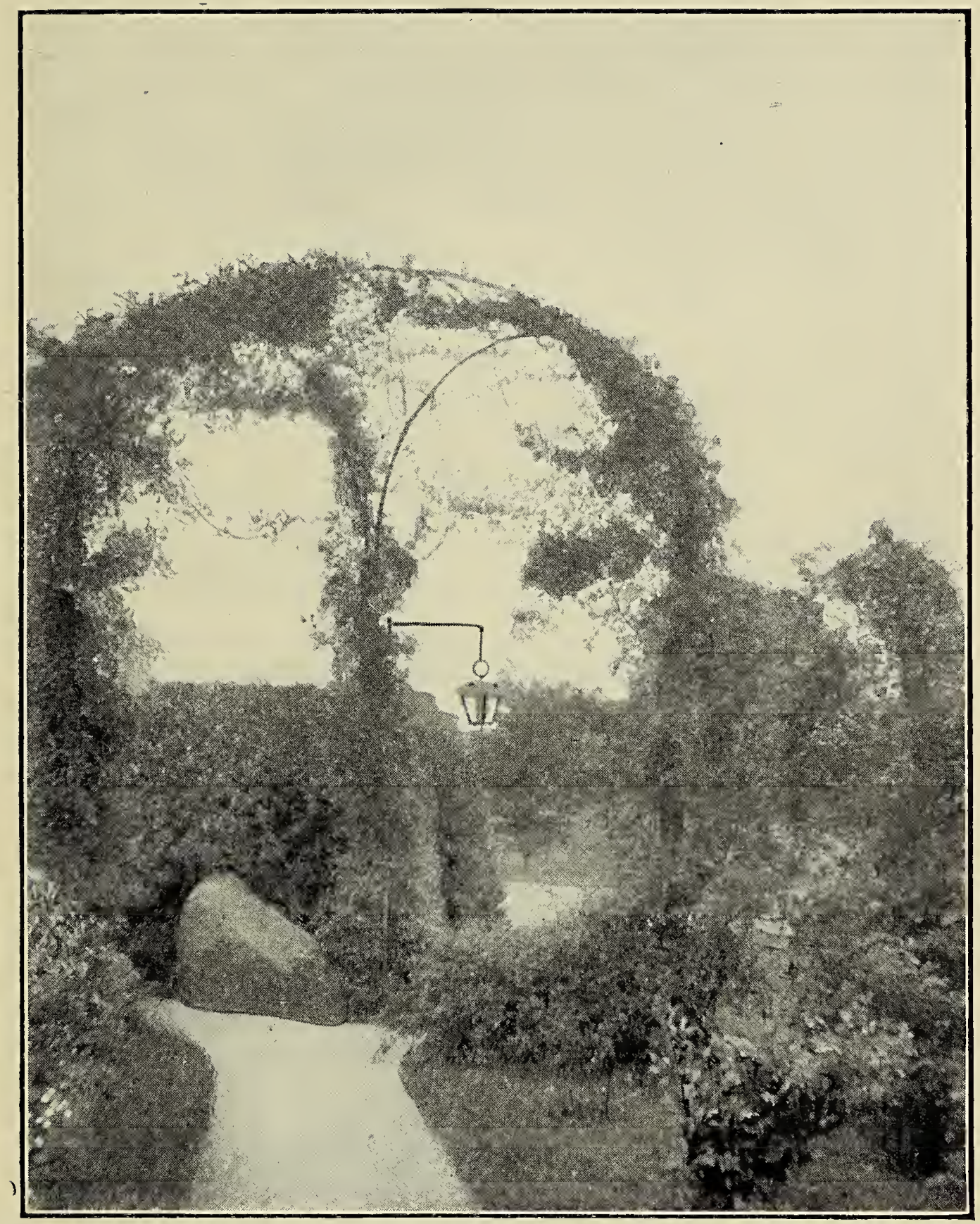

PLATE XLII.-WICHURAIANAS OVER ARCHES 

"I know his ways," she answered.

Yet the day was not cold. There was merely the same little bite in the air that the frost left when passing away in late April. The mist hanging over things now keeps us from seeing their outlines sharply, and in this September reminds me again of the early spring.

Joseph has ordered the bulbs that he intends to plant between now and the time when the ground freezes too hard to make such work possible. He has also bought twelve white peony roots, in order that the bed of peonies we have dreamed about may become a reality. Four double pink ones, as well, are to be set in the triangle proper. The large bed for the peonies has been prepared by Timothy in the usual way, since we wish to give them every chance to flourish next spring. At least a foot and a half of the soil has been dug over and a layer of well-rotted manure been put at the bottom of the bed. We have remembered that peonies like full sunlight.

Already Joseph has planted a hundred Spanish irises, all supposed to have yellow flowers next season; he also has set out fifty English irises, named Mont Blanc, perhaps because they are so white. These he expects to bloom after the Spanish ones have faded. If these plants do half as well as Joseph anticipates, we shall have a wonderful showing of irises next spring, and for very little money. The hundred Spanish irises cost but 
a dollar, and the fifty English ones were only a little more than double the price.

Joseph planted these irises in September, because he wishes their foliage to grow before the winter begins. He says that in November he will cover them over quite heavily with straw, since they are not absolutely hardy, as are the German and Japanese irises which we planted last spring. But under warm covering he thinks they will rest in comfort.

With the exception of the peonies and irises, Joseph will probably wait until October, or even November, before putting in the rest of his bulbs. It is well, however, to. have the above number out of the way before the real autumn planting begins. The irises were set deep in rich soil, their roots being rather long and eager for room. Joseph planted them all by the moist point of the triangle in irregular groups. I love irises, and have encouraged him to set out so many in our garden. Even when the flowers are gone, I like to see their sword-like leaves sharp and distinct among the surrounding greens.

Joseph has bought besides yellow crocuses; snowdrops, of both the small and the large varieties; Siberian squills, which pleased us so much at Miss Wiseman's last spring; the lovely narcissus poeticus; double yellow daffodils, yellow tulips, and those that bloom later called parrot-tulips. With these latter, we were both so enchanted last spring 
that, for a while, we thought we would plant no other tulips. In the end, however, we chose from the catalogue the solid yellow ones for earlier blooming.

We bought no hyacinths. We do not care for them as much as for the other spring flowers, and they cost more. In this instance, Joseph and I considered ourselves fortunate in having our taste correspond with our pocket-book.

After Joseph had made out his list of bulbs from the catalogue, he took it to show to Miss Wiseman before actually sending the orders to the nurserymen.

"Master Joseph," she said, "you have shown good taste as well as economy."

The order was then sent in. Now that the bulbs have arrived, Joseph looks at them several times a day with the same air of mysterious wisdom and admiration that he had for the seed packages last March. He is as serious about his bulbplanting as I was in starting my rosarium.

It is, however, because Joseph has been serious regarding the garden that he has made it a success this first year. If he had continually put it aside for other things, instead of attending to it each day, planting and transplanting when the hour was ripe, the garden must have suffered and worn a melancholy, unkempt look. Nothing is more distressing than to see a neglected garden. Some- 
thing must be wrong with the one who planted it, or he would not let his early work so go to waste.

Joseph watches and waits until the seeds he sows or the flowers he plants require his aid. Then they find him ready. Mrs. Keith declares her treatment of the yellow cat was kind in comparison to what Joseph has given to the pests of the garden. They would never have ventured within its limits had they known about his spraying, his mixtures and the way he handles wood ashes. In killing these creatures, Joseph seems to find a sort of pleasure which I am not sure is always good for him. But then it would be wrong to allow them to devour our flowers.

To-day Joseph and I have been again to Nestly Heights. The drive up to the house is most lovely. In places it appears almost as if we were in a dense wood, one where everything is tidy and where flowers and shrubs bloom as nowhere else. In the real woods, the flowers and shrubs are now dying. No gardeners, of course, are there, as at Nestly Heights, to remove flowers that have passed their bloom, to pick off unattractive seed-pods, and to scatter about odd and brilliant plants. Large banana leaves were waving with the breezes as we drove along, and many cannas held aloft either red or yellow flowers.

"There must be something grand about owning a place like Nestly Heights," Joseph said, while the same feeling crept over me that I had when he 


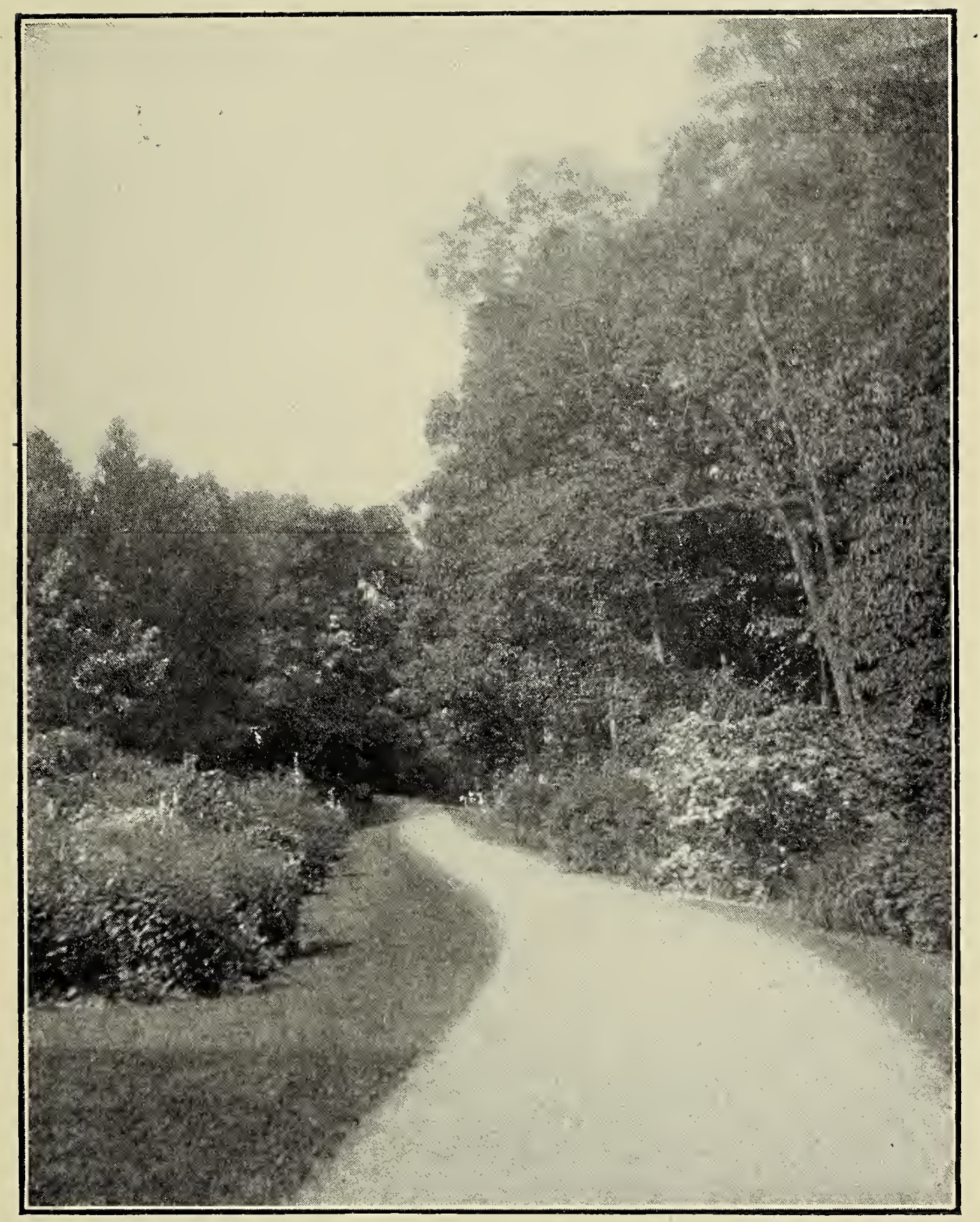

PLATE XLIII.-THE DRIVE UP TO NESTLY HEIGHTS 

won the tennis tournament. This time it was not the dread that he would forsake the garden for athletics, but I wondered if, when he became a man, with affairs of his own, he would grow very rich and dissatisfied with the Six Spruces. I have heard Mr. Hayden say that, when he was Joseph's age, the only garden he knew about was one in which turnips and cabbages grew. The thought of Joseph's growing to be a man was overwhelming. I had never concerned myself about it before.

Mr. Percy came in when we reached the house, and Ben and Harry tumbled about Joseph, both talking to him at the same time. Mrs. Hayden was sitting on the veranda in a little corner away from the wind.

"It is useless for me to play I love the autumn," she said. "I cannot forget how near it is to real winter."

There is something very delicate about Mrs. Hayden. She is like a white lily that has begun to fade. It would not seem natural for her to help Joseph, to stake out flower beds and pass the line around, as Miss Wiseman did. But, although she is so quiet and moves around so little, every one loves her dearly.

This day Mr. Hayden was not a bit like the wind, or even like a little breeze. He had gout in his foot, and it pained him severely. 

said.

"My boy must show you around to-day," he

I looked for Little Joseph, but already he was on the tennis court, so Mr. Percy and I started down the long walk that leads to the glass houses.

"We will not bother to go into them all," he said, "but in this one I will pick you such a bouquet as you should always have."

We stepped into a part of the house where roses grew and where they were all pink, perfect and waxy, while at their base, hanging over the raised beds, were quantities and quantities of heliotrope. In this warm house it grew prolifically, more like a vine, in fact, than the upright plants in our bed at the Six Spruces.

"Do not pick it," I said. "It will only wilt, since we have not hot water in which to put it."

"But it goes so well with the roses," Mr. Percy replied, "and the two together go so well with you."

It was not a bouquet that he gave me, but an armful of flowers, pink roses and heliotrope. As we were leaving the house, we passed the head gardener. I saw him give Mr. Percy a very severe look.

"If they had been mayflowers on some wooded bank, or columbines," Mr. Percy said, "I should not have dared to pick so many, even for you, Miss Amanda. The wildlings need protection. But gardeners exist for the purpose of giving us pink roses and heliotrope." 
I thought that perhaps he would be scolded for the reckless picking he had done, quite as much as if he were Ben or Harry.

We talked about his going back to college and how near the time was when Joseph would have to go to school.

"I shall run back for Thanksgiving," he said, "and then, you know, I shall be down again at Christmas-time."

"But," I said, "there will then be no garden at the Six Spruces for you to come and see."

"I may drop in then," he replied, "just to see you and Little Joseph."

"We shall be shut up in the library," I told him, "but, if there is a log fire, it may not seem dull."

"No," he said, "it will not seem at all dull to me."

As usual, it was hard work getting Joseph to realise that the time had come to stop playing tennis. I was eager to reach home before my flowers faded. He came at length, and we hastened along, as it had begun to sprinkle slightly.

"That will be my last game of tennis for some time," Little Joseph said later. "From now on, until the garden is made ready for winter, I shall have as much work here every day as I can manage."

So again I was made sure that Joseph would not forsake the garden. 


\section{CHAPTER XXXII}

\section{CHRYSANTHEMUMS}

$\mathrm{HE}$ hardy chrysanthemums have come with Oc-
tober. They are the ones we planted along the upper end of the wall before the nasturtiums are reached, which, as I must have mentioned before, were brought to us by Timothy Pennell. When he set the little plants out, I suppose he saw, in his mind's eye, as he says, how beautiful they would one day look in our garden. A few of them are white, but more are purplish crimson. They are like autumn itself, and seem as much a part of it as the changed leaves and the white frost which wishes to come and which yet holds back a while.

Yesterday, at Miss Wiseman's, we saw some of the most wonderful chrysanthemums that ever unfolded. They grew in one of the glass houses at Nestly Heights, and were like solid balls of white or yellow petals. One had petals of deep wine colour, lined with yellow. I cannot write down half the wonder or the beauty of these flowers. Miss Wiseman said Mr. Hayden had sent them 


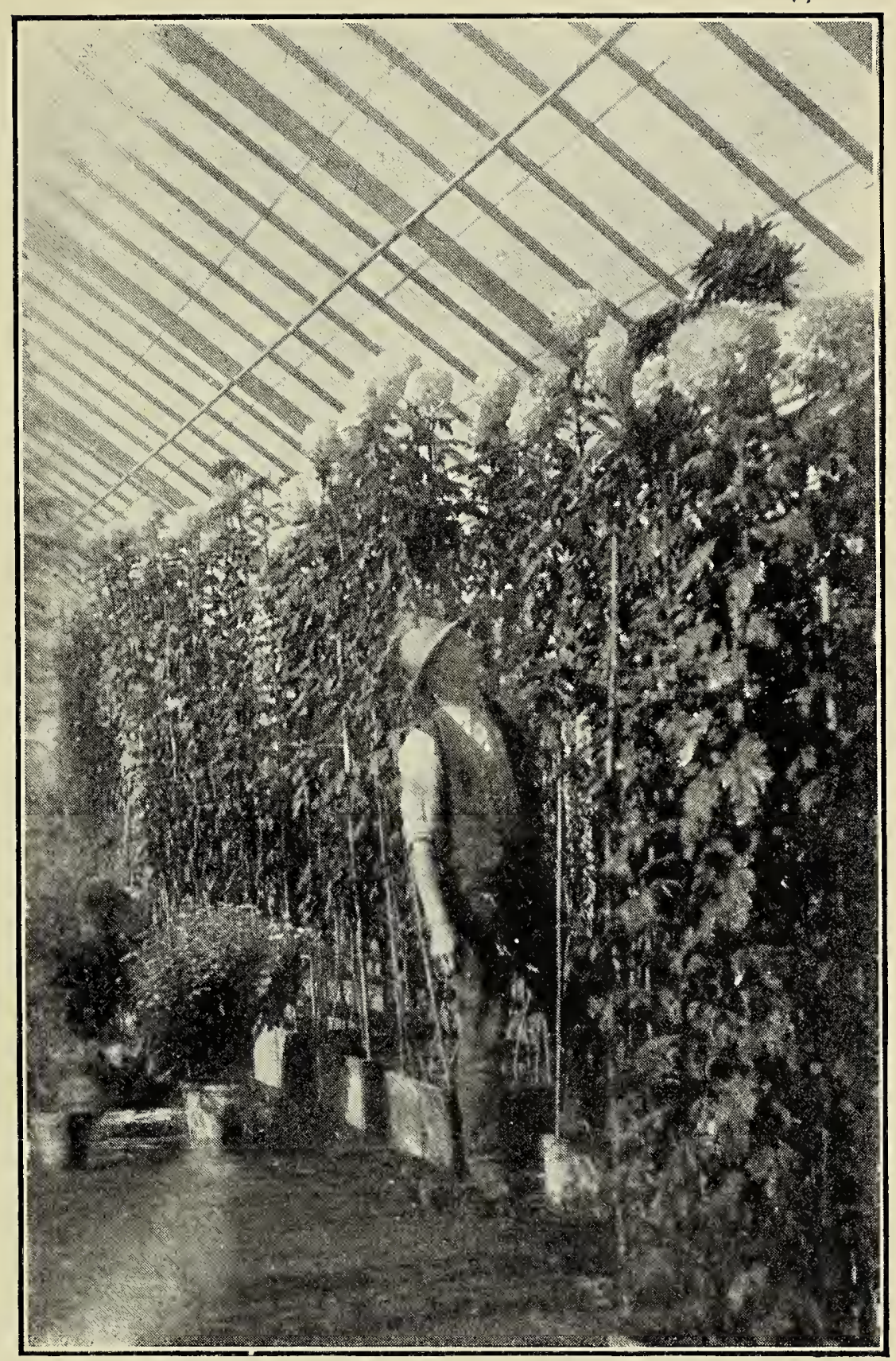

PLATE XLIV.-CHRYSANTHEMUMS IN THE GLASS HOUSE AT NESTLY HEIGHTS 

just to let her see what could be done at Nestly Heights, because she had beaten every one of his dahlia exhibits at the show. They were more marvellous than I had thought chrysanthemums could be, but they were no more like the hardy ones in our garden than if they had borne a different name.

Ours are to love and make bouquets with; but the great hot-house chrysanthemums are to admire from afar. I wonder that these flowers should know how to dress in autumn colours when they have been raised in the warmth as much as were the pink roses and heliotrope $\mathrm{Mr}$. Percy picked for me. How do they find out there is a chill in the air, and that the leaves have turned red, crimson, yellow and bronze? Do they send out white flowers, I wonder, because they are forerunners of the snow? Perhaps no more than did the sweet alyssum of our garden. Chrysanthemums invariably give me this thought. These great ones never seem young to me. I imagine they have lived long and have conquered much.

We shall never have chrysanthemums of this kind at the Six Spruces, unless some day Joseph grows very rich and hires skilled gardeners to work for him, while he looks on and smiles. But every year, and in increased numbers, I hope we shall have the kind that Timothy brought us.

They are flowers that never tire me. They seem to wish to help me say good-bye to summer and 
the garden, and yet to do it without complaining. They are free and fearless, and remind me of birds that have lived outside of a cage.

In the spring, when Timothy was dividing his own chrysanthemums, he brought these to the Six Spruces. He set them out, putting three or four sprouts together, and since then they have been scarcely any trouble. In early July, and again during the first week of September, Joseph dug in about the roots of each plant a small trowelful of manure, because chrysanthemums, like roses, need a very rich soil. Then he kept the new shoots and the buds pinched back until September, so that they should grow bushy and not bloom before the autumn call for them came clearly.

Next spring, when these plants begin to sprout, we shall divide them as Timothy did his this last season. Looking into the future, therefore, I see an increased number of these late visitors at the Six Spruces. We have learned that they do best when planted in rich soil where the sun can linger upon them. Also, they like a wall. Some day, when we make our wide border about the house, we may plant them against its sunny side. During the long weeks before they bloom their foliage is always pretty, the leaves being a soft, ashen green. I like them much better than the phloxes, which are so prim before they bloom and become so unattractive after their heads are cut off.

While I was thinking of our chrysanthemums, 


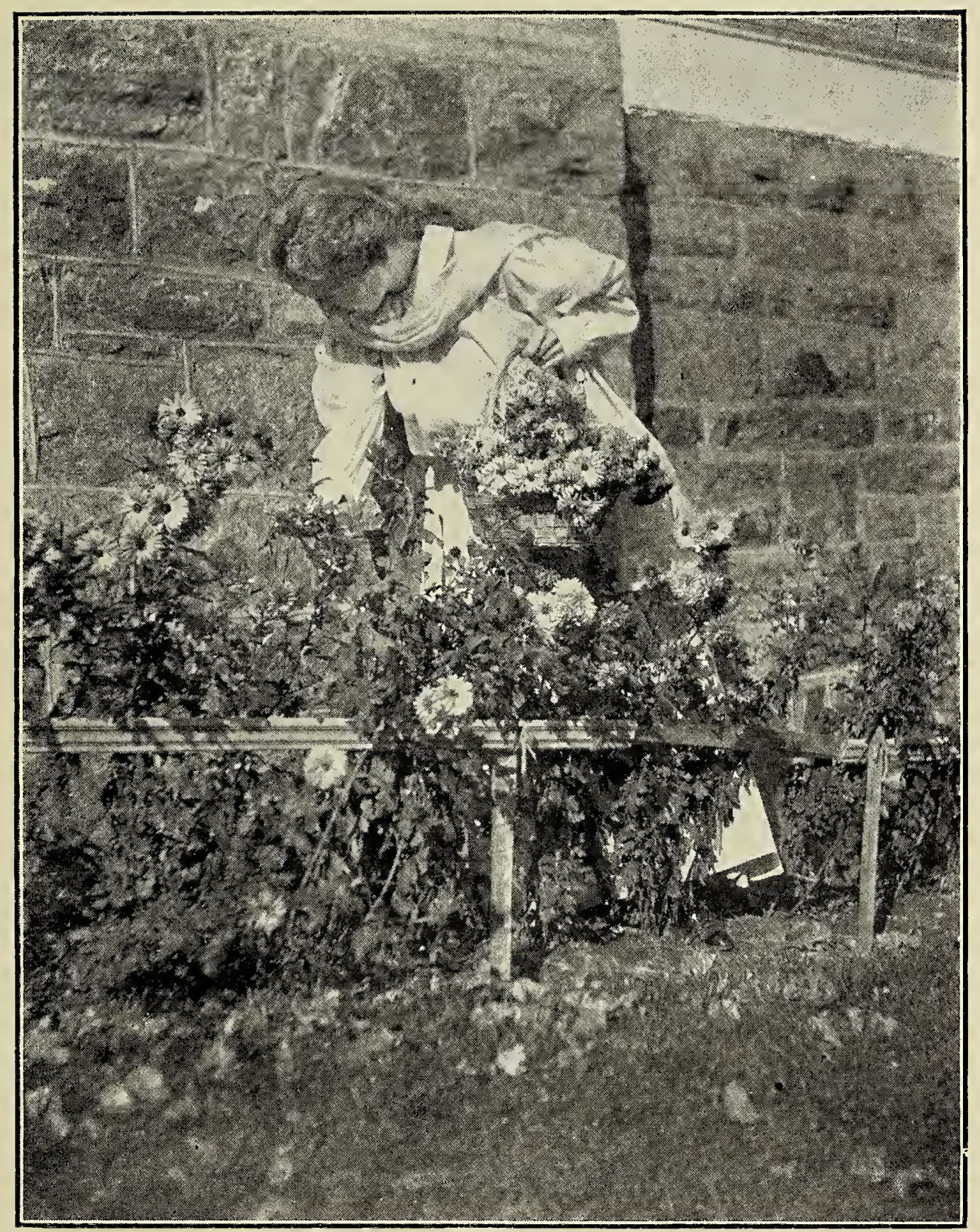

PLATE XLV.— "THE CHRYSANTHEMUMS THAT TIMOTHY BROUGHT US" 

and noticing the strange scent they waft to the nostrils, it began to rain, in a way that made me know it was no mere garden sprinkling. We have been rather suspicious of rains since the great storm that ended in taking away our spruce tree. This rain appeared one that would really soak the ground, and was in the right quarter, Mrs. Keith said, to last two or three days. As long as it remains a sensible autumn rain, without wild gusts of wind, Joseph and I shall be content. He needs some time indoors to think seriously about where he will plant the bulbs, and to settle in his mind several other matters. While he thinks, reads and makes notes in his book, the rain will be doing much towards preparing the soil. But Mrs. Keith has suggested that I bestir myself in the linen closet, and plan about curtains to hang up for the winter. This is different work from that in my rosarium and roving about the garden helping Joseph. I suppose I shall mind it less when the flowers are actually dead, or sleeping under the snow.

From the wood-border the trees are waving branches all golden or scarlet. The sumacs growing by the roadways are flaming red, while over our wall the Vrginia creepers have become more deeply hued each day. The rain now is preying on these colours. It is taking from them their sparkle, blending them all together. From the library window, we see the leaves falling. They 
do it gently, almost without ceasing, as though they were snowflakes.

"I shall plant all of the yellow crocuses in the circle in front of the house," Joseph said, as though to break the monotony of the rain. "Then, when people drive in the front gate next spring, they will be as surprised as we were the day we went to Miss Wiseman's and saw the snowdrops in bloom."

"Do you think we should have curtains in the library?" I asked.

"I was speaking about the crocuses," he reminded.

"But Mrs. Keith says I must think about the house now," I told him, "and curtains are important."

"Then you had better have them," Joseph made answer.

A bird flew close to the window, as though trying to get in. Indeed, he knocked himself against the pane.

"Perhaps this storm will grow wilder," Joseph said, and then returned to the subject of bulbs.

"Did you know," he asked first, "that Timothy sowed a great deal of grass-seed here on September twentieth, and that, before doing so, he took up many weeds and later rolled down the new seeds? They have probably taken root, and will have a fine start before cold weather. So, you see, a good lawn is already prepared for the bulbs to be set in." 
"I suppose you will put them in with the English bulb-planter," I said, "so as not to hurt the lawn."

"Naturally," Joseph replied. "Planting bulbs in that way is scarcely any work at all. I can manage to slip in about three dozen every half hour. I shall plant them below the grass-roots, probably between three and four inches deep, and, in places where they are apt to be touched by manure, I shall put about them a handful of sand."

"So that is the reason Timothy dumped that pile of sand by the side of the wood-border path," I said, and Joseph nodded assent.

"It was in the autumn," I then reminded him, "that we were to buy our weeping willow tree. You said it should be set out at this time."

"Let us go after it now," Joseph exclaimed eagerly. "We can drive to the nursery right away."

"The rain?" I said.

"It is only softening the ground for autumn work."

Mrs. Keith's nephew, who works in the stable, harnessed our horse to the old rockaway wagon in which Aunt Amanda used to drive, while Joseph and I ran for our raincoats and galoshes. The curtains were down on every side of the wagon. Inside, it was as dry and comfortable as in a little house. When Mrs. Keith caught sight of us, we were settled on the front seat covered with the waterproof sheet, and Joseph was driving. 
"Your Aunt Amanda would never have allowed you to go out in this rain," she called after we had started. We, however, were off, and it would have been foolish to turn back then.

The nursery is quite three miles from the Six Spruces, and we found it necessary to drive slowly, the roads were so muddy. Once there, we left the rockaway and tramped up and down the rows of young trees. It was "great fun," as Miss Wiseman tells us American girls enjoy saying; but in another way it was unwise for us to have come to the nursery. Before this, Joseph had sent his orders by post, and, when the things came, we were delighted. Here in the nursery, however, we saw so many beautiful shrubs and plants that we wished for them all sorely, although we should never in our sound senses have dreamed of ordering them by post. For an instant, I even felt that perhaps I should prefer having some other tree than the weeping willow.

Joseph would not listen to such a whim. "You have always wished for a weeping willow," he said, "and now is your chance to pick out a good one."

Then we walked in a little grove of these trees, and at length decided on one with a straight stem that was fairly well grown.

"Shall we go back now?" Joseph asked, thinking to avoid temptation.

My eye, however, had been caught by another grove of trees with leaves like stars, turned to most 
brilliant shades of red and yellow. I inquired their name.

"Oh, they are sweet-gum trees," the nurseryman said, adding under his great moustache, "Liquidambar styraciflua."

"They are beautiful!" Joseph exclaimed enthusiastically. "We have nothing at all like them at the Six Spruces."

"They grow well and rather quickly," the nurseryman urged.

"How much would one cost?" I asked boldly, for, after all, this was the vital question.

"Well," came the answer, "I would let you have that large one there for eight dollars."

"We will take it," I said promptly, and then wondered why I had done so. Joseph never uttered a word.

The nurseryman marked a tag with our name, and said he would bring it and the weeping willow over and plant them for us as soon as the rain ceased. He wished, he said, to show us his Hercules'-clubs, aralia spinosa, fine shrubs for ornamental planting; but Joseph already had me by the arm, and we were running as fast as we could towards the rockaway.

"Eight dollars!" Joseph exclaimed, when we were once inside. "It is more than we have ever paid for any one thing before."

"But it is less," I said, "than a new winter hat 
for me would cost, and the tree will live as long as we do."

The wheels then were going farther down in the mud than when we had started out. 


\section{CHAPTER XXXIII}

THE AUTUMN WORK

THIS week, when it is nearing October fifteenth, 1 Joseph has again been busy transplanting perennials that have come up from the seeds sown in the bed last spring to the places where they are to remain permanently. This has not only required activity on his part, but a good deal of thinking and imagination. He has to keep continually before him the picture of the garden as it will look when these plants are in bloom, and also how they will appear when they have grown old. By planting them now, he hopes to have them rooted before the ground freezes, when they may rest undisturbed until the time comes to make an early start in the spring. With these added to the perennials we planted early, much ground that was bare will be covered and flowers will decorate the triangle in bolder masses than heretofore.

As Timothy says, our garden stock is all young. This means that none of our hardy roots is large enough to require dividing and resetting at this time of year, which is often necessary in older gar- 
dens. Miss Wiseman has now many men at work doing this for her. Yesterday I noticed that, before setting the plants, the men often put a spadeful of manure in the bottom of the holes. In fact, each man, in addition to his tools, had a wheelbarrow full of this stuff somewhere near. Much richness of soil is necessary to make flowers large and strong; and who would wish to save manure at the expense of having small and puny flowers? Miss Wiseman would give us some of the perennials she has divided this autumn, but Joseph thinks we have a sufficient start, and wishes to let our garden increase itself. From now on, he is going to be very careful about taking in new plants. He prefers to have many of a few kinds well massed than to have a few strange, lonely ones here and there.

We are delighted, however, with some plants that Miss Wiseman has given us, particularly the lilies-of-the-valley. We had not thought of them until Miss Wiseman sent us a large quantity of the pips to set out. The bed for these flowers, and that for the white peonies, are in fact the only new ones we have made this autumn.

We planted these lilies between the rosarium and the wood-border. There the lilies will have the shade they require, and we can see them from the garden seat as well as the roses. When Timothy prepared their bed he first dug out the soil for about two feet, put at the bottom some old manure, and filled the hole up with rich, fine earth, through which 


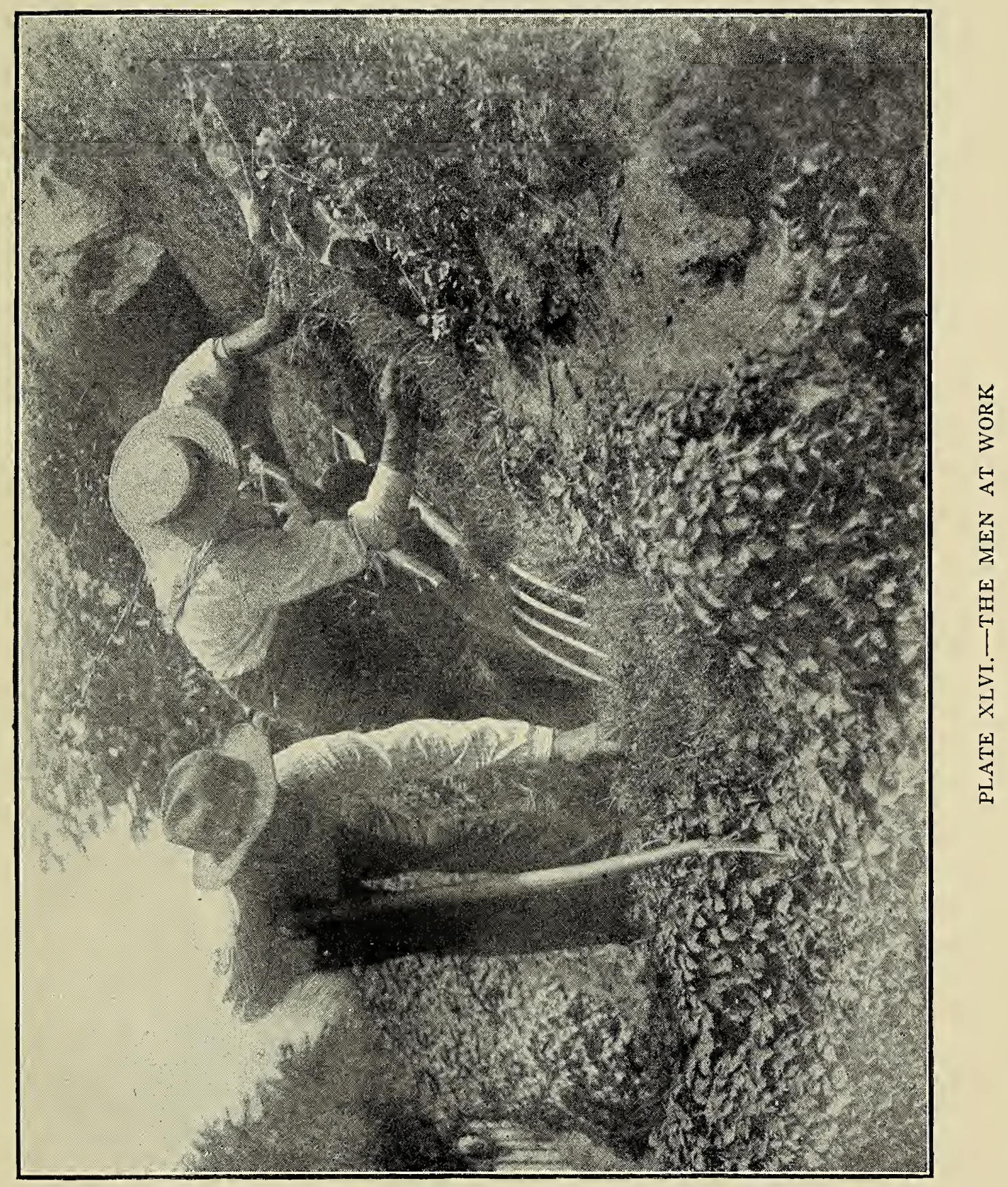



some leaf-mould from the woods had been mixed. After it had thus been made ready, I helped Joseph set out the pips, as the roots are called. I shall have an especial love for this bed of flowers, as I have for those of the roses and heliotrope. It is too bad that we shall have to wait until May to see them in bloom.

Without telling me a thing about it, Joseph has kept a piece of news in his head about lilies-of-thevalley.

"They are wild flowers," he said casually, as we . were planting them.

I thought he must be talking about something else.

"Oh, I do not mean that we shall ever find them growing wild, near here," he explained, "but in parts of the southern mountains of the United States they are as much wild flowers as rhododendrons and azaleas are wild shrubs. They spread themselves over the hillsides and fill the air with fragrance when they are in bloom."

I asked him how he had found this out.

"One day, when Mr. Percy was reading a magazine article," he ansiwered, "lilies-of-the-valley were referred to as not being natives of this country. Mr. Percy then ran his finger over the text and said it was all a mistake, because he had seen them himself growing wild in the higher Alleghanies."

"Let us hope they will grow here as if they were 
wild," I said, knowing Mr. Percy must be right in the matter.

"And bloom like mad," Joseph added.

Miss Wiseman also offered us bulbs of other lilies, called respectively lilium candidum, auratum, and album. They will bear several fine lilies on each stalk. We noticed them in bloom this summer, but we have lost our desire for them. Although they are hardy, they look as if they have just stepped out of a hot-house. So we said we would not take them now, but that, when our garden was older and we knew its needs better, we might find a place just suited to them. Joseph said perhaps we would have an inspiration about them during the winter, and then we could plant them in the spring, after the frost had left the ground. "Spoken like the wise boy you are!" Miss Wiseman replied simply.

This week he has continued to plant the snowdrops through the turf of the triangle. They are such dear little flowers, and will come up so early, that we wish to keep them as near us as possible, right in the heart of the garden. They are not for the whole world to see, as are the gay crocuses scattered through the front lawn. The Siberian squills are strewn about somewhat at random. Joseph is playing that they are wild flowers coming up of their own accord.

More thought, however, had to be given to the planting of the tulip bulbs. Now they are set as 


\section{THE AUTUMN WORK}

a ring about the bed where the heliotrope is planted, and in the space formerly occupied by sweet alyssum. They have also been used as border plants to the long bed in front of the wall. When they have bloomed and faded, other border plants that are not likely to disturb the bulbs will have to take their places.

Joseph has no intention of taking up his bulbs, after their foliage has turned yellow, storing them over the summer, only to replant them again in the autumn. His plan is to cut off their leaves when they are dead, and to follow the old-fashioned way of letting the bulbs remain in the ground to ripen and to increase. At the end of three years, he will perhaps dig them all up and have their bed made over and enriched, although at present this seems a long way off.

Joseph has planted the narcissi near the crescent bed at the end of the triangle. They are not in the bed, but behind it in the grass. There the turf is not cropped close and turned into lawn until after June, when the foliage of the bulbs will have died. It is quite necessary to think of the foliage of bulbs when planting them, and to arrange that it need not be cut down until its strength and life have returned to the bulb. Should the foliage of narcissi or tulips be cut off while fresh and green, their bulbs would greatly suffer.

The daffodils have been planted in the grass in 
the same section of the garden, where we hope they will live and increase for many years.

I was glad when Joseph had completed his bulb. planting, and had hung his useful implement up in the tool closet. Some days he looked very tired, although he would never acknowledge to weariness of any sort.

Little Joseph goes to school now, and all the work that he has done this month has been either before going or after his return. At half after eight every morning the carriage from Nestly Heights stops here for him, and he drives away with Ben and Harry. His school began two days after Mr. Percy went back to college. The garden then seemed to me more lonely than if all the birds and flowers had left. Now I am growing used to their absence. I take music lessons each week, and Mrs. Keith has made up her mind to teach me many things about the house. Then there are my roses.

About the tenth of this month I set in the fan a few hardy perpetuals that were sent to me by $\mathrm{Mr}$. Percy. They had been cut back so that they had no especial appearance to recommend them, and they were not tagged. I shall have to wait patiently to learn their habits until June returns and they send forth their petals. Manure has been^dug in about the base of the rose-bushes, and any deadwood that may have formed has been carefully cut out. With the exception of cutting back my roses, 
there is not much to be done to them until late in November, when a heavy winter covering will be spread over the ever-blooming ones. Timothy is raking the fallen leaves in piles, not to burn as bonfires, however, but to use in forming protection for tender roots.

Mr. Hayden will send one of his gardeners to help me cut back the roses this year, for, being so inexperienced in this work, I fear I might trim them either too much or too little. Miss Wiseman advises me to follow her rule, in which case she says "all will be well."

In November she cuts her hardy roses back to about two feet in height, and the monthly or everblooming ones she trims down to about a foot. Some day I shall perhaps see for myself how wise it is to cut back roses in the late autumn; but now it seems to me a rather cruel thing to do, when all summer they have been striving so bravely to grow.

I wonder what would really have happened to Aunt Amanda's blush-rose bush if, during all the years gone by, it had been under the care of Mr. Hayden's gardener. The roses might have been larger, but surely they could have smelt no sweeter, and perhaps the bush would not have lived so long.

I have other thoughts about roses, which I shall not write down, however, until I have watched the rose fan for several more seasons. In fact, I may only let them be known after I have become as 
famous for my roses as Miss Wiseman is for her dahlias.

All this time Joseph and I have not forgotten to watch the shrub that Timothy Pennell had given us and planted in the wood-border-the queer one that he said would only bloom when other flowers had fallen. It is in bloom now, covered with small yellow flowers, very frail and straggly. They give a curious appearance to the dying leaves about, and, for an instant, I thought they, too, were dying, having turned yellow in so doing. On looking closer, I saw that they were quite as much alive as were the yellow bells that covered the shrubs in April. Spring came among our shrubs in yellow and now the witch-hazel wears the same colour as autumn departs.

Nothing could have pleased Timothy more than the way this shrub behaved and bloomed in its new home.

"It is a fine one," he said, "a real fine one, and as lively as a cricket."

Of late Timothy has been in the clutches of the farmers. He is away in the fields loading wagons with corn and pumpkins, and tying the stalks in stacks which stand like an army in waiting through the fields. The autumn mist hangs over them, turned in the distance to purple, while the ground becomes rich with the leaves that once the trees upheld. 


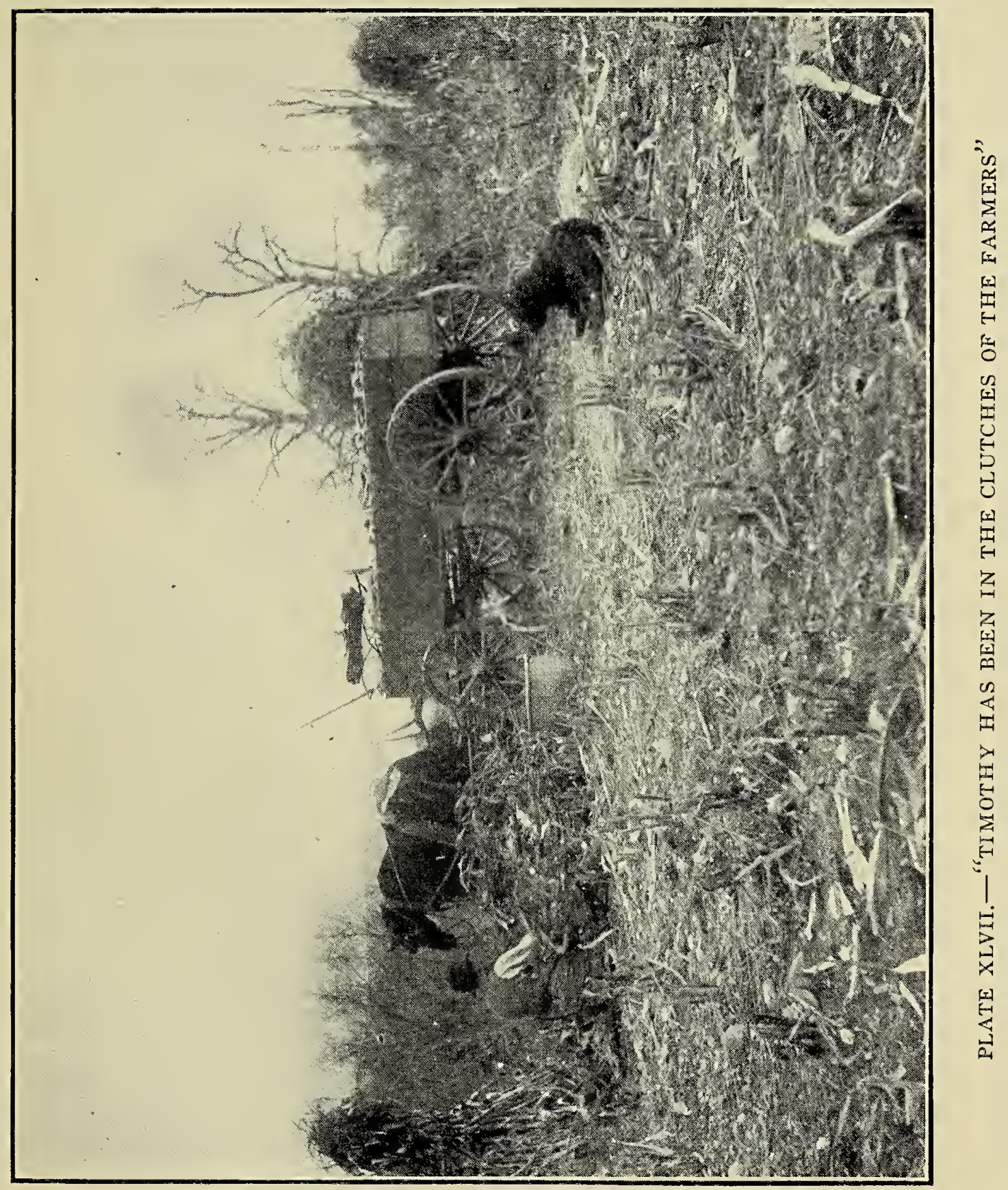





\section{CHAPTER XXXIV.}

\section{DAYS NEAR THANKSGIVING}

I AST night a frost intensely white spread itself $L$ over our garden. It was whiter even than the last of the cannas that faced it so unflinchingly and were killed by its touch. The few remaining heliotrope flowers grew black at its coming, and the cheery nasturtiums that had hidden themselves beneath their leaves from former frosts quite gave in to this white visitor. Indeed, how should any of these survive when even the hardy chrysanthemums lie dying?

In the rosarium, the monthly roses have been covered for the winter with manure, leaves and cedar branches over all. They have had also warm cloaks of straw wrapped around them. No vestige of their former stateliness remains. They look like queer little pigmies playing at being as important as the cornstalks in the fields. The hardy perpetual roses have been covered more lightly; mulched, in fact, with coarse litter.

All of Joseph's young perennials have been covered, many of them with cedar boughs to keep the 
wind from scattering the warm, dried leaves spread over them like a blanket. Everywhere about the triangle, and extending to the wood-border, there has been a clearing up and a making ready for winter. Neatness prevails in our garden. To me it looks quite dead.

Joseph persists it is only sleeping, which, of course, I know is true. Yet this sleep of the plant world is very different from that of people. When the "sandman" calls for Joseph, he merely closes his eyes and his body loses its sprightliness. I can see him and feel him just the same as if he were awake. But when the garden sleeps, it fairly vanishes from sight. It is almost as if it had never been. The tops of the hardy perennials have been cut off and taken away as rubbish. Still, Joseph reminds me that they are not dead but sleeping.

I think I should like to peer deep into the earth and look at the roots of the plants while they are sleeping. I wonder if they have the same appearance then as when upholding their stalks of flowers. Wonderful happenings must go on in the soil where they live, or various roots looking more or less alike would never be able to send up so many flowers of different shapes and colours.

If any of our perennials fail to come up next spring, I shall believe that they have taken cold in the earth and been unable to live. The sensations of a plant when it is cold must be truly dreadful, as they cannot call out for aid or in any way 
help themselves. We must be more than careful that they are covered over and kept warm and snug.

The trees of the coppice now appear to me as dead as the garden, although they also are merely resting. Their leaves have fallen aimlessly in many places, and we see again their frameworks as distinctly as in early spring. Yet with this difference : in spring, even during raw and chilly weather, there shone upon the twigs and branches of the trees a glimmer of life, a slight hint of colour. Now they appear to grow more sombre every day. Grey and dull brown have taken the places of pink and yellow. The few stray leaves that still cling to the branches look as if only waiting their turn to fly off with the next passing wind.

At the point of the triangle, too, all is dead, but there is still a fluffy look from the tall grasses and straggly sticks that have not died down to the ground. It presents a contrast to the extreme neatness of the flower beds. Nothing has been covered over except the Spanish and the English iris bulbs, and even the roughness of this litter gives here an appearance of life.

"Do not tidy up things at the moist point," I said to Joseph, "until it has the still, dead look of the rest of the garden."

Again he corrected me and said that the garden was only sleeping.

Since the leaves have fallen, we see clearly many 
birds' nests. But they are empty, their usefulness being long since past. I feel a little desolate about these nests. They tell so plainly that the birds have gone, and that there is a long wait before their return. One black individual remains that claims November for his own. The crow fits in with the sombre day and its spirit. When sky and trees are grey, he takes to flight, rising, as it were, from nowhere. He is the blackest note in the landscape as he flies off, perchance to help Timothy in the cornfield, for crows delight in feasting on the farmer's corn and seek the left-over ears which occasionally stand out from the stacks. Poor creatures! the kernels in such ears are hard and dry. Who but a miser would begrudge them their meal ?

Joseph insists, however, that crows are cowards and have not the highest standard of morals. But I have only heard of one really wicked crow, while those I now see about quite cheer me. I do not agree with people who think they make this time of the year more dreary. They give a life and a sound to its greyness.

The wicked crow I know about stole and probably devoured a young chicken. It happened in the spring when chickens are tender and at the age to make good broilers. Timothy Pennell's son had raised a number for the market, regarding them with pride and expectations. One day from the window he saw a crow sweep down from the broad sky, and take back in the air with him one 


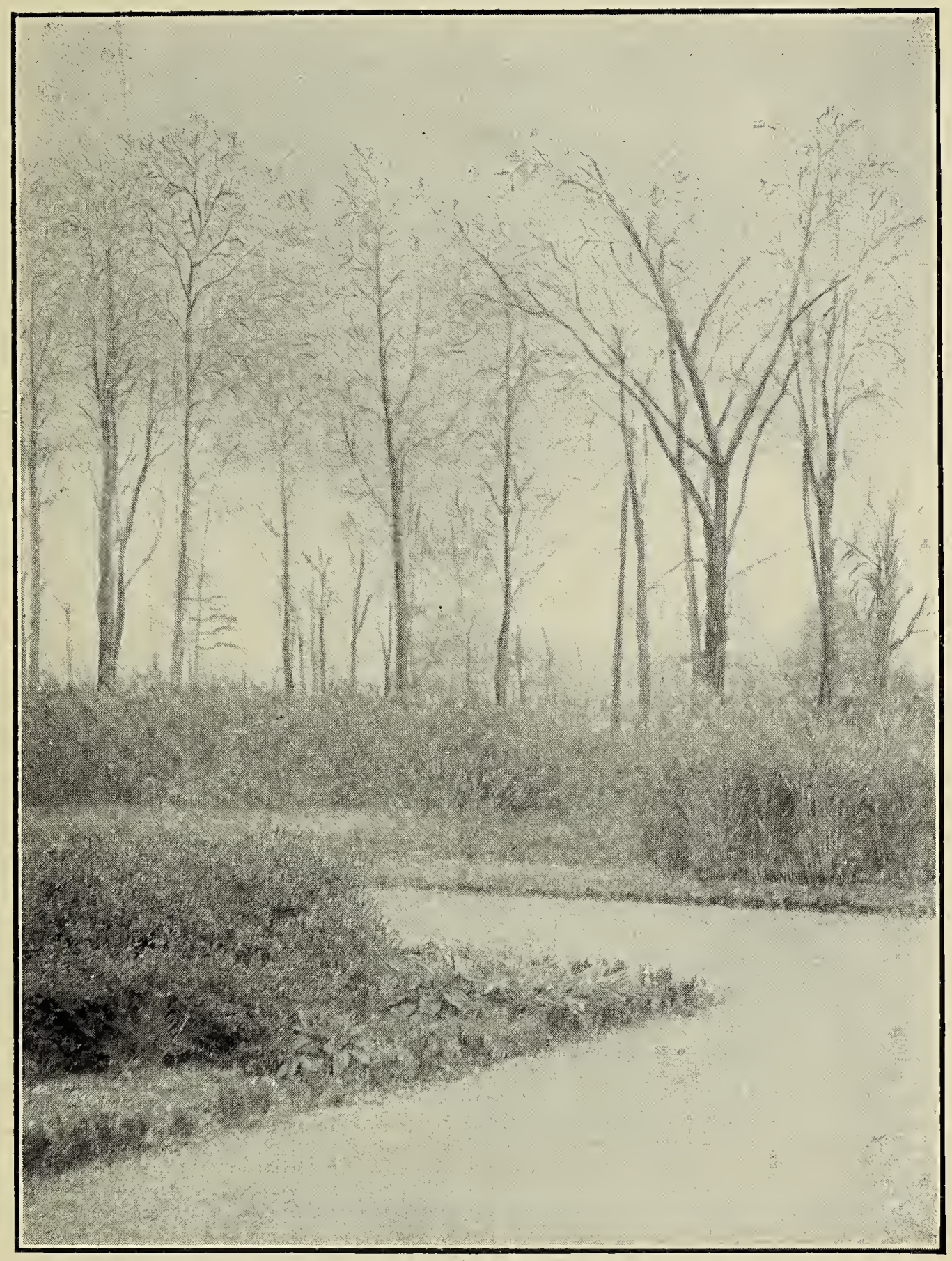

PLATE XLVIII.-- “AT THE POINT OF THE TRIANGLE ALL IS DEAD" 

of these chickens. His father was working outside, but had not seen the occurrence. Timothy's son, quickly opening the window, called loudly to his father: "The crow has a chicken, the crow has a chicken!"

Unfortunately, Timothy had his poor ear turned in the direction of his son's voice and thought the words were: "The horse is a-kicking, the horse is a-kicking!"

So, instead of running to the house for his gun, he started as fast as he could go towards the barn, in order that his feeble old horse might be disciplined. In the meantime, the crow and its prey passed out of sight. At first, it had flown rather slowly and stopped once to rest in a tree. Probably it was unused to carrying such a large bird as the chicken.

Timothy's son is lame and could not himself run quickly after the crow. Since this happened, neither he nor his father has had any good words to say for crows, nor in fact has Little Joseph. I think myself the chicken came to a tragic end; but, if it had stayed with Timothy's son, it would soon have had its head chopped off, so the difference was not so great after all.

Queenie Perth no longer talks about her garden or the butterflies. "There is nothing to say now about it," she explains. And this is true, since, with the exception of a few sweet-williams, all her flowers were annuals, living for one season only. 
They are now completely dead. When spring returns, she will sow the same seeds over again, and have another garden identical with the one of this year. Now her hands are idle, as far as garden work is concerned. She has done no autumn planting, nor was there any need for her to cover over anything.

"Auntie does those things in her garden," Queenie says; "mine is for Rosamond and the butterflies."

We have noticed that, whenever Queenie wishes to take no trouble or to do a thing in a childish way, she invariably says she does it to suit her doll Rosamond. Every morning now she goes to school with a little bag of books under her arm; and, from the way her brow is puckered, she must be thinking seriously of many things.

It is not likely that any one about the Six Spruces will forget Joseph's dislike of dandelions and the feeling of pride he had in thinking he had banished them from the triangle. Yet, as I walked about to-day, a gay, golden head nodded to me amid the greyness of the garden. I stooped to scan it closely. It was a dandelion blossom as fresh and undaunted as if it were May instead of November, the rosette of its leaves appearing perfect. I found it near the moist point, where Joseph has not been as vigilant as in other places.

I was pleased with the welcome of this little dandelion. Its bloom cheered the whole garden, 
and made the thought of winter seem less long, while spring drew nearer. I guarded its whereabouts with secrecy, expecting to count the many dixys it stayed in bloom, and to see if it would succced in makir $g$ its ball of seeds before the first snow f. 1. I had not, however, taken Saturday into acco nt, the day that Joseph has no school.

$\mathrm{Ne}$ were at breakfast that morning when he said: "Just think, I found one of those pert little dandelions in bloom."

"What did you do with it?" I asked.

"Do with it?" he queried. "I took it up and destroyed it, of course."

So perished the last flower of our garden, and for no better reason than because men call it a weed.

"Do you realise," I asked, to change the melancholy subject of dandelions, "that it will soon be Thanksgiving, and Mr. Percy will be home again?"

"I have a composition to write before then," Joseph answered in an extremely doleful way.

"That is nothing," I said. "You just begin-"

"It is the beginning of a composition that I detest," Joseph said savagely. "After that, it is not so bad."

I remembered that compositions are hard to begin, and sometimes hard to end, but that the middle parts give no trouble.

"Just like our garden," I said. "In spring it 
was hard and almost discouraging to begin; then came the middle, easy time, and at the end it grew hard again and dreary. Only," I continued, "you can put a cheerful ending on any composition, while it is difficult to have lively thoughts about a garden that is-"

"Sleeping," Joseph interrupted, knowing the ugly word I was about to utter. "I could write the composition about our garden," he said eagerly. "Such a beginning as that would not be hard, because there is so much to say. Probably I could not get the composition all on one sheet of paper. Besides," he added, "there is not another boy in the school who could write a composition about a garden. No one else there has ever made one, and only a few boys even know the names of the flowers. I think I will begin this evening."

Joseph was then as ready to begin his composition as he had formerly been fearful of the undertaking. He had simply settled on a subject that he knew something about, and one which filled him with enthusiasm. I knew that, once he was fairly started on his work, his observations would be quaint and different from those of the catalogues and garden books. Joseph can express himself as well as most boys. Suddenly, I looked at him with an awakened interest. Would the day ever come for Joseph to write a better book than "An Ambitious Boy's Garden"? 


\section{CHAPTER XXXV.}

\section{THE SNOW}

SINCE our garden has bloomed its best, and $S$ now rests sleeping, and since there is no longer any work there for either Joseph or me to do, we have turned to the spruces for greenness, and to the woods in their silent gauntness. We are not content to live apart from Nature, even though she wears the cloak of winter.

The snow began in the night. Joseph and I awoke to see the outside world changed from greyness to the black and white of December. The flakes continued to fall silently throughout the morning, each one making the whiteness more complete and spotless. The trees rose darkly above it, while a solitary crow, the last perchance of his fellows, flew directly across the triangle as though intent on leaving it and its whiteness as far behind him as possible.

"Now you children will learn something about life in the country," Mrs. Keith assured us. "Winter is the real time to test the patience."

Timothy Pennell, who has changed his occupa- 
tion of gardening for the less imaginative one of taking care of the furnace, stamped the snow from his boots and said stoutly: "Now we are in for a good long spell of rough weather."

He said this so buoyantly that it seemed as if he were quite pleased with the prospect.

Joseph's one idea when he saw the snow was to get out into it, to make it into snowballs, and to fire them at the clothes-posts for lack of any more vital objects. He arranged that, later, our horse should be harnessed to Aunt Amanda's old sleigh, and ransacked the garret for robes and bells. He was joyous and alive to the pleasure of the snow, and I wondered he did not fret and fume at being shut up in school while the earth wore this wonderful white covering.

I felt more timid with the snow. It gleamed so white and was so cold. As soon as Joseph had gone to school with Ben and Harry, I returned to the house, keeping my eyes away from the windows. With the snow had come a restlessness. I could not read or think of my music, but wandered from room to room. Mrs. Keith came and said she would teach me how to make mince pies. I was only spared this ordeal by the ringing of the front door bell and the blustery appearance of $\mathrm{Mr}$. Hayden. He wore a great fur coat and a fur cap, and to his beard the snow was clinging.

"A day like this makes me feel young again," he 
said, "but you, Miss Amanda, look as pale as a lily."

I told him I was a little afraid of the snow.

"You mean you do not like to have Joseph away at school and my boy off at college," he said, drawing a newspaper out of his pocket. From this he shortly began to read. I found out that Mr. Percy had made a speech somewhere, and that every word of it was printed in the paper.

"That is the kind of a son to have," said Mr. Hayden. "One of these days he is sure to set the world on fire."

Just why Mr. Hayden should be eager for him to do such a terrible thing I could not imagine; but I agreed with him that he was the very best kind of a son.

"Ben and Harry," he continued, "will grow up like me and, when they get old, they will have gout."

It seemed too bad to predict such a future for these jolly boys; but, nevertheless, I said that Mr. Hayden was right.

"Now, Joseph," he said, "is a rare combination. $\mathrm{He}$ can make a garden and play the violin as well as my son Percy, and he can beat those other boys of mine at tennis."

This time there was, of course, no doubt about my agreeing with Mr. Hayden.

Then Mrs. Keith came in with some mincemeat 
for us to taste. In despair at Mr. Hayden's visit, she had proceeded to make the pies alone.

"Mincemeat and a snowstorm," Mr. Hayden exclaimed. "Nothing could be better," and he settled down to tell the real object of his visit.

He had decided, he said, not to leave Nestly Heights for town before January, and it therefore rested with him and with me to give every one a surprise for Christmas. "You remember," he added, "that my boy Percy will be home the day before."

"It must be a secret," Mr. Hayden said impressively, "between you and me. I will lure all the neighbours to Nestly Heights on Christmas eve, and then I shall come out of the chimney dressed as Santa Claus."

One of the rooms at Nestly Heights has a chimney so large that Mr. Hayden could be hidden in it behind some evergreen boughs. We planned that he should wear the fur coat he then had on, and that Mrs. Keith should find a white beard for him. I said that I would make him a large bag to hold some of the presents he had to give away.

Then we talked for a long time about what he would give Miss Wiseman and Queenie and Mrs. Keith, whom he thought would be difficult to please. He told me that he already had something for Mrs. Hayden, and for some one else whom he knew, 
and that it was easy enough to find things for those boys of his.

"I will give one a tennis racket," he said, "and the other a football."

Then he told me as a very great secret that he intended to give his son Percy and Little Joseph the best presents of all, although what they were he was careful not to mention. The third secret Mr. Hayden told me was that he was having the Christmas tree made.

"Yes," he said, "it is to be an artificial tree; one that can fold up and be put away so as to be ready for all other Christmases to come. I do not approve," he continued, "of cutting down our splendid evergreens for Christmas trees. They are becoming scarcer every year. It is a barbarous custom to chop down a beautiful tree that it may give a few hours' pleasure. My son Percy does not approve of this custom, either. $\mathrm{He}$ would be shocked if I should have a real evergreen tree at Nestly Heights on Christmas eve, and I should no longer be able to preach to people about the preservation of our evergreens. Yes," he said again, "I am having my tree made. There is too much fun in preaching to have to give it up."

Mr. Hayden was certainly in excellent spirits. I promised to keep all his secrets and to help him as much as I could to bring about his Christmas surprises.

"Not a word of this to Little Joseph," he said 
before he went away, "nor to Queenie, nor to my son Percy when he comes home. Not a word!"

I smiled at Mr. Hayden then, for already I knew the surprise Mr. Percy had planned to give his father at Christmas.

"Not a word to anybody!" and Mr. Hayden blew out of the door with a great puff of snow.

I was glad when I heard the bells ringing and saw the sleigh turn in at the Six Spruces bringing Little Joseph back from school. His cheeks were red, and he was full of gaiety.

"Our vacation has begun," he cried. "Just think: vacation, snow and Christmas!" Little Joseph was happy.

Then we looked across the circle and saw Queenie Perth trudging through the snow. At first, it seemed impossible it could be she. We wondered how it happened that Miss Wiseman had let her come out in such deep snow. Long before Joseph reached her, we heard her laughing.

"I slipped out to feel the snow for myself," she said. "Auntie was whispering secrets about Christmas that I could not hear."

She was well bundled up, and as eager to play in the snow as Joseph. They pelted each other with snowballs, and at length they decided to build a great snow man and to stand him by the spruces. Fortunately, Timothy showed them the way he used to make one when he was a boy. Otherwise, they 


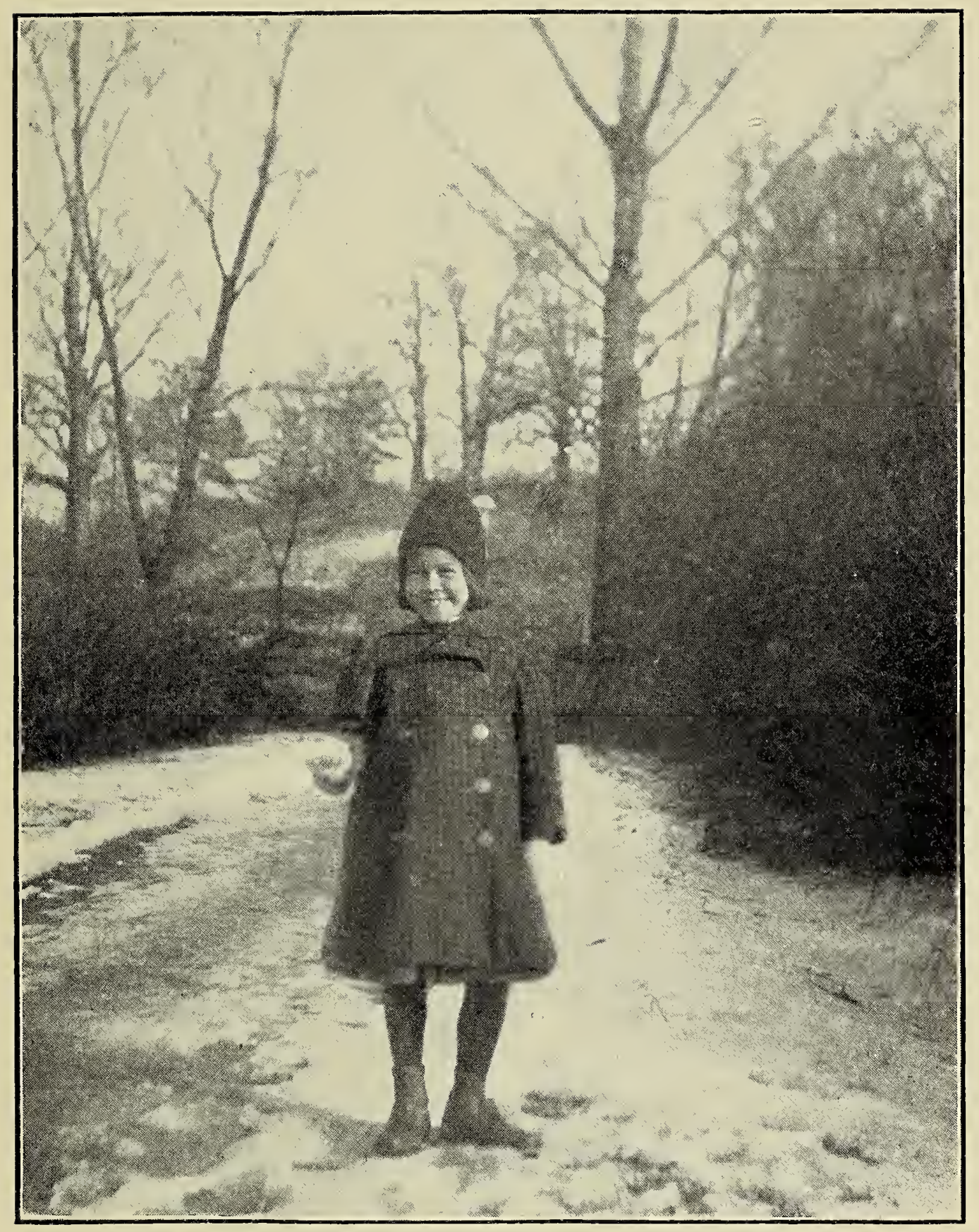

PLATE XLIX.- "QUEENIE TRUDGES THROUGH THE SNOW" 

would never have succeeded in building a man so large and so steady.

Miss Wiseman's sleigh and merry bells came through the gate long before the man was completed.

"It was no use trying to keep Queenie away from the snow," she said. "I made believe I did not see her putting on her rubber boots; but all the time I knew that she was here playing with Master Joseph."

Miss Wiseman was completely wrapped up in furs, and, for the first time, I was impressed with the fact that she was a very great lady. She seemed no longer so decided and boyish as when she had worn a short skirt and tramped and worked in the garden with Little Joseph. Still, she had perhaps changed no more than he. His overalls were hung up in the closet. Even when I looked at myself, I thought my appearance had changed somewhat with the putting away of blue jeans and rubber gloves. I did hope, however, that $\mathrm{Mr}$. Percy would not be a bit different when he came home for Christmas.

"So we have only to enjoy the snow and get ready for Christmas, Master Joseph," Miss Wiseman said. "Like all people who work well, we much appreciate our play spell."

Master Joseph at that moment looked as if he were doing so. Since the garden had gone to sleep, not even the shadow of a weed had crossed his 
brow. And well might it sleep under such a soft, white coverlet. No insects could annoy it now; no weeds would overcrowd the flowers. I do not believe that Joseph had forgotten the garden. In his sensible way, he was content to let it sleep.

"On Christmas," Queenie shouted, "I am going to have a new doll and a new butterfly net, and enough candy to make me sick for a week!"

Joseph asked her how she knew.

"Oh," she answered, "Auntie finds out what I wish, and then tells Santa Claus."

There was a mischievous twinkle in Queenie's eyes. It was one of the moments when no one could tell whether she was serious or not.

Before the sun went down, we all had a drive with our own horse in Aunt Amanda's old sleigh. Two days more would bring us Christmas eve and the party at Nestly Heights. The same time would bring Mr. Percy back again, and almost too soon I thought our first Christmas at the Six Spruces would slip over our heads. Mrs. Keith has declared that so far we have done nothing to disgrace our great-aunt.

While our garden sleeps, Joseph and I are thankful that here in Nestly we found so faithful a helper as Timothy Pennell and such good neighbours as Miss Wiseman and Mr. Hayden of Nestly Heights. We do not believe that there is another little, girl so whimsical and so wise as Queenie Perth, nor another who has tamed a butterfly; but, 
if there should be one anywhere, I think the flowers themselves would wish to grow and look at her. When at length Mr. Percy is through college, we hope he will always live near our garden, for without him it will seem as strange as when the birds are gone and the black crow flies off alone.

I cannot write now about the day when Little Joseph will have become a man, nor shall I spend time wondering if he will then care for and work in the garden. I know that I, who am nearly grown, will love it forever. 



\section{INDEX TO FLOWERS}

A

Adam's-needles ........ r I9I

Alyssum, Sweet. 57, 59, 66, 16r

Anemone, Japanese....54, 244

Annuals .........56, r68, 21 I

Aphis $\ldots \ldots \ldots \ldots \ldots \ldots$ I 45

" Blue..........223

Apple Blossoms........ I22

Aralia Spinosa......... 259

Arbutus, Trailing....... 107

Asters ........222, 229, 239

" Wild...........2234

Azaleas ............... I 18

Azalea Lutea............ Ir8

"Mollis....II7, I18, I9I

B

Baby's Breath.....17, 109, I 52

Banana Leaves.........248

Beauty, Painted......63, 148

Bedding-out Plants...... I27

Biennials ..........56, I88

Bird-houses ......... 5

Black Birds ........... 7

Bloodroot ..........54, 73

Bluebirds .........6, 20, 47

Blue-eyed Grass, Pointed. I24

Blue Flags, Wild.....102, Ir 3

Bluets ............. 106

Blush-rose Bush... I0, I3, I31

Brakes ...........126, I6I

Bridal-wreaths ........34, I 37

Bulb-planter .........25, 257

Bulbs ..........245, 265

Butterfly, Migration....2 23I

Milkweed..... 23I
C

PAGR

Candytuft ....59, 66, 147, r61

Cannas ........ 128, I91 248

Canterbury-bells ....... I89

Ca-dinal-flowers..I 7, I09, I25,

$205,212,229$

Catbirds ............196, 217

Cherry-trees........... I I

Chipping Sparrows...... roo, I 38,174

Chrysanthemums ....97, I03, $225,251,269$

Cinnamon Ferr........ 74

Clematis Paniculata.88, 90,233

Clio ....83, I30, I3I, I64, 201

Columbines $\ldots \ldots .58$, 99, I 3

Wild......1 3,136

Correspondence ........ I7

Cosmos ......177, 179, 185, 239

Crawford, Mrs. R. G. S. 83

Creepers, Virginia.... 88, 89, $229,237,255$

Crimson Ramblers . 85, 165, 236

Crocuses .....24, 40, 246, 264

Crows ..........272, 277

Currant-bushes ......... Io, I I

Cutworms ........... I75

Cyclamen ............. I27

D

Daffodils ........ 108, 246, 265

Dahlias ...3, 127, 128, I91, 240

Dandelions .........123, 274

Delphiniums .......... 156

Deutzia ............ 34, 36, 38

Dog's-tooth Violets..... 73 
Dogwood .......... I I0, I 36

“ Red-twigged.34, 36, 38

“ Pink............ I I0

Druschki, Frau Karl.. .83, I30

Dutchman's-breeches .... 54

\section{$\mathrm{E}$}

Eulalia Japonica........ 205

Everblooming Roses.... 82

Evergreen Shrubs....... I77

Ferns .........72, I6I, I68

F $\ldots .72, \mathrm{I} 6 \mathrm{I}, \mathrm{I} 68$
$\ldots \ldots . . .74,78$

“ Lady ............76, 78

“ Maidenhair .....74, 78

Fiddleheads .........72, 78

Forget-me-nots $\ldots . . .126,206$

Foxgloves .......... I87

\section{G}

Geraniums .........9I, 239

Ginger, Wild........... 94

Gladioli .......127, I28, I9I, 220,222

Golden Bell..........34, I03

Golden Glow......97, I95, 229

Goldenrod ............. 234

Grackles .............7, 92

Grapevine ........... Io

Grasses, Ornamental..204, $27 \mathrm{I}$

Grass Seed...........I4, 256

$\mathrm{H}$

Hardy Roses.......... 82

Heliotrope ....... I03, I75, 229, 250,269

Hen-and-chickens....... I 27

Hepaticas ........8, 4I, 73

Hercules'-clubs ........ 259

Hollyhocks . . .58, 103, 198, 200

Honeysuckle Vines....88, 236

Humming - bird, Rubythroated ............ II 4

Hyacinths ........... 247

Hybrid Perpetual Roses. 82

Hydrangeas $\ldots . .34,36,229$,

232,240
I

PAGE

Insects .....II6, I45, 223, $24 \mathrm{I}$ Insecticides. . I I6, I45, 223, 241

Iris ..97, 102, 104, I26, I68, 204 " English........245, 27I

“German.. I02, I I3, I36, 246

“ Japanese..... I02, I36, 246

" Mont Blanc......... 245

" Spanish........245, 27I

Ivy, Poison.......... 89

$\mathrm{J}$

Jacks-in-the-pulpit....... 108 Japanese Anemones... .54, 244 “ Azalea ........ I I7

" Gourd ........ 88

" Iris .... I02, 136, 246

“ Maples ....... 2I4

“ Morning-glory. 88

“ Plume Grass... 205

Jonquils ............. 108

\section{$\mathrm{K}$}

Kaiserin Augusta Victoria .............84, 22I

Kerosene Emulsion...... II6 Killarney Rose......... 84

L

Lady-bugs .......... I 6, , 93

Lady-fern...............76, 78

Laing, Mrs. John....... 83

Lambkill ............ 178

Larkspurs .....997, IOI, I56,

Laurel, Mountain....... I I8

Lawns ............... Io, I4

Leaf-mould .......... I27

Lemon Verbena........ IO, 20I

Lilacs ..........35, I Io, I2I

Lilies ............. I I

Lilies-of-the-valley $\ldots \ldots . .262$

Lilium Album ......... 264

“ Auratum ........ 264

“ Candidum .....160, 264

Lily, Common Pond..... 203

Liquidambar Styraciflua. 259

Lotus Lily............ 203

Luizet, Madame Gabriel. 83 
M

PAGE

Maidenhair Fern...74, 78, 20I

Manure .........49, 82, 262

Maples, Japanese.......2 214

Maréchal Neil......... I45

Marshall P. Wilder...83, I30,

Meadow-larks ......... I57

Meadow-rue ........ IoI, I56

Mignonette $\ldots .57,59,66$, I36, I6I, 20I, 229

Monthly Roses......... 82

Moonflower .......... 88

Morning-glory ...I4I, 2I 5, 236 Japanese.. 88 $\mathrm{N}$

Narcissus Poeticus....53, ro8, 246,265

Nasturtiums …57, 59, 65, 88, I36, I70, 269 “ Climbing ..65, 228,

" $\quad 236$

Neyron, Paul........... 83

Orchids ............. 94

Oriental Poppies ...58, 62, I 34 Osmunda Cinnamomea .. 74 Oswego Tea........... 2I4 Owl, Screech ........... I75, I87

$P$

Painted Beauty.......63, I48 Pansies ....... 3, 70, I27, I90 Passion-flower ......... 88 Peonies .........98, I24, 245 Perennials ....56, 97, I69, 21 I, 261, 269 261,269
$\ldots .236$

Perle des Jardins......84, 200 Petunias ...........15, 215 Phlox .....997, I00, I72, 223, ". 224, 228, 239 “ Drummondi ....59,62, Phœebe-birds ........208, 21 2 Pickerel-weed ........... 204
Poison-ivy ........... 89

Poppies, California...... I 83

"Oriental..... 58,62

“ Shirley...59, 67, 183,

185, 238

" Yellow ......180, I83

Portulaca ............217

Prince Camille de Rohan. 83

Pussy-willows ........ 23

\section{$Q$}

Quaker-ladies ...... Iо6, I24

$\mathrm{R}$

Ramblers, Crimson.... .85, 88 Red-headed Woodpecker. 77 Rhododendrons ....... I04, I 8 Rhus Cotinus ......... 34 Robins ............. I00, I40 " White ......... 225 Rosarium ........... 80 Rose-beds .......... 8I Rose Bugs.......... 200 Rose-bush, Blush...Io, I3, I3I Rose-mallow ......212, 229 Roses ..........I44, I64, 250

" Climbing ........ 85

“ Everblooming ..82, I44,

"،- 267

“ Hardy. .82, I44, 266, 269

“ Hybrid Perpetual.. 82, I 44,269

“ Monthly ...82, I44, 21 I, 267,269

Rothschild, Baroness.... 83

\section{$\mathrm{S}$}

Salvia ............ I9I, I92

Seeds ................ I59

Seed-bed $\ldots \ldots \ldots \ldots \ldots \ldots, 48$

Screech-owl ......... I75, I87

Shirley Poppies....59, 67, I83.

I85, 238

Shrubs, Evergreen...... I77

Siberian Squills.......24, 40,

Smoke-bush ......34, $\begin{array}{r}245,264 \\ \text { I96 }\end{array}$ 
Snowdrops $\ldots \ldots .24,246,264$

Soleil d'Or.......83, 144, I49

Solomon's-seal, False.... I I 5

Song-sparrows ....... roo

Sowing Annual Seeds...58, 64

Perennial Seeds. 58

Spikenard, Wild......... II5

Spirea ........... I , 36, I37 Van Houttei...... I37

Spraying Outfit........ I I

Spruce Trees.......... r8I

Squirrels, Flying....... I93

Starling $\ldots \ldots \ldots \ldots \ldots$ I38

Stocks, Ten-weeks..... I7, Io9, I68, I69, 223

Sweet-gum Tree.......259

Sweet Pea Trellis......30, 32

Sweet Peas ......27, 37, I55

Sweet-williams ... I72, 220, 273

Syringa, Sweet.......34, 36

$\mathrm{T}$

Ten-weeks Stocks.....I7, I09, I68, I69, 223

Tobacco-water ........223

Tool Closet ........... I9

Tools ............... II

Triangle, Map of the

Tuberoses ............. I9I

Tulips ..........53, 246, 264

" Parrot ..........246

$\mathrm{U}$

Ulrich Brunner.
V PAGE

Victor Verdier......... 83

Vines ...........215, 236

Violets, Dog's-tooth..... 73 Yellow ....... 94

Virginia Creepers......88, 89, $229,237,255$

\section{W}

Wake-robin ......... 77

Walks, Grass-See map. Gravelled-See map.

Watering ....... 26, I64, I68

Water-lilies ......... 203

Weeds .......8, I29, I4I, 207

Weeping Willow......I3, 257

Weigelia ............ I I

Whippoorwill ......... 94

Wichuraiana Rose.....85, 204

Willows ............. I2

" Pussy ......... 23

Windflowers ........54, 75

Window-boxes......... I6

Witch-hazel ..........45, 268

Wood - border, Making the .........106, 107, 108 Woodpecker, Red-headed. 77

Worms' Nests.......... 222

Wrens $\ldots \ldots \ldots \ldots \ldots .20,92$

Wren's Egg............. 6r

\section{Y}

Yellow Bell Shrubs.... II, 34, 36,54 





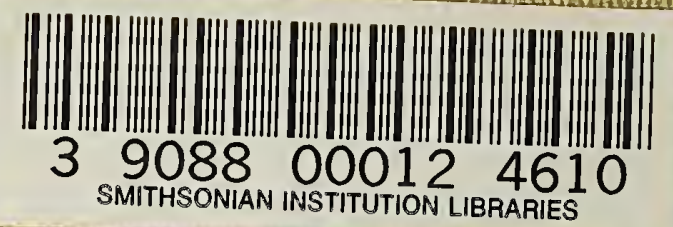

